58 

$=$

$+1$ 

AS ABELHAS 



\section{EDUARIOO SEQUEIRA}

AS

\section{ABELHAS}

TRATADO DE IPICLETLRA MOBHSTA

ILLUSTRADO COM ZU (X) GRAYITRAS

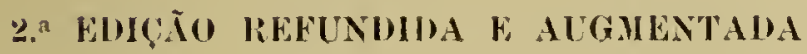

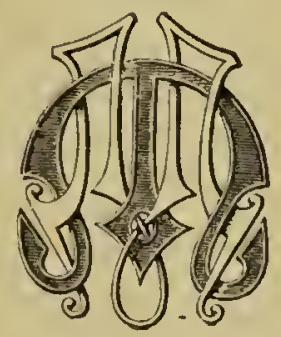

POR'LO

MAUALHAES \& MONIZ - EUITOLE

Largo dos Loyos 


\title{
DO MESUO AUCTOR
}

\author{
15re Os reptis eme Jortugat

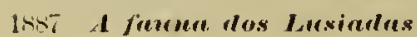

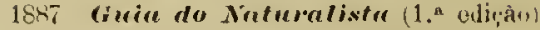 \\ 1888 (rmia do Natmralista $\left(2 .^{2}\right.$ edicâa) \\ 1888 Nimbose Oros \\ $18 x 9$ d heira mar.

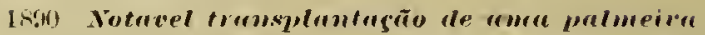 \\ 1891 Esbogo biographico de Adolpho Frealerico Moller. \\ 1889, 1890,1891 o 1892 Jornent de Horticuttura Pratira \\ 1892 Lemirs dos veyetues \\ 1,804 y 1595 Jomnt de Agrimutura e Horticultura protion

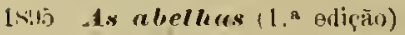 \\ 18:4 La culture des rosiers en Porlugul \\ 184 o.s chrisuntlemos \\ 1899 Que fuzer dos nossos fülhos:? \\ 1900 Notas Horticolo-ayricolas
}


A

\section{ALBERT'O VELLOSO DE ARAUJO}

e

\section{BENTO CARQUEJA}

smigcs querides

= amigos sinceros des abeihas 

A

MEU BOM AMIGO E APICULTOR ENTHUSIASTA

Snr.

Christiano Van-Zeller 



\section{AS ABELHAS}

Noçues geraes sobre os insectos - Os hymenoptéros Papel que desempenham na fecmudação dos regetaes

Tiram os insectos o nome da particularidade que thes 6 greralmente commum de possuirem o corpo como que cortado cm duas partes distinctas, como rêmos, por exemplo, na mosca, na formiga e na respa. O que essencialmente distinguc os jusectos, separando-os de alguns myriapodes e aranhas com que o vulgo geralmente os confunde, são as metamorploses por que passam antes de chegarem á fórma perfeita e propria para a reprodueção. Julgou-se durante muitos seculos que no insecto existiam tres individuos differentes. Foi Swammerdan, o Galiler do infinitamente pequeno, quem, pela rez primeira, con um assombro bem justificavel. viu, na larra do insecto, não só os rudimentos das azals mas ató os oros da futura borboleta. Esta descoberta, plenamente confirmada mais tardo com o aperfeiçoamento das analyses microscopicas, vejo mostral que o desenrolvimento de todos os sìres 6 Larmonicamente igual entre si, e que, súmente uns, como os insectos, soffrem as mudançass le fórma fóra do oro, emquauto os mammiferos, as ares, os reptis e os peixes se transfor- 
mam no oro, apparecendo, excepto no tamanlio, semelhantes áquelles que llies deram origem.

O mundo dos insectos é infinitamente prodigioso comparado com o de todos os outros sêres. Pela sua immensa força muscular, pela arte, pelo excepcional colorido, pelas brilhantes scintillações com que nos embellezanı as noutes, pela fórma de viver, e, principalmente, pelos beneficios que nunitos nos prestam, são os insectos os animaes mais curiosos da creaç̃o e os mais dignos de particular c especial estudo.

O insecto artista e é gnerreiro. Armado de todos os instrumentos necessarios para o seu variado trabalho é um industrial activo para o bem da progenie. Mas ai de quem o atacar! As armas de paz transformam-se em potentes machinas de exterminio e os venenos, os narcoticos e os acidos que queiman, leram a morte c a assolação por toda a parte por onde elle passar.

O amor que 6 a rida e a alegria, que transforma, desenvolre e aperfeiçoa todos os sêres, é para o insecto a morte. Anıando morre, soffrendo o martyrio cruel de não clegar a vèr a descendencia querida. Os animaes superiores acompanham, amparam e educam os filhos ató á idade d'elles poderem prescindir da protecção e carinhos paternos; mas os insectos apenas pódem ceruar de cuiclados o oro, para que as larvas, ao nascer, tenhan tudo o que lhes é ncessario para poderem facilmente viver.

Mas que intelligencia não nos patenteia cntão a mãe borboleta, que não come, por isso que, tendo de virer como insccto perfeito apenas o tempo indispensavel para operar a postura, não tem necessidade de alimento algum, mas que, recordando-se do que comen 11 a sua primeira phase da vida, não depõe nunca os oros senão no vegetal proprio para 0

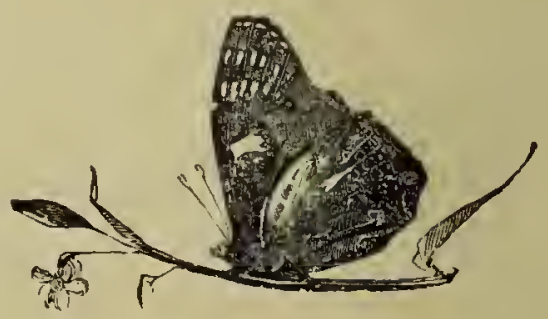

A màe borboleta 


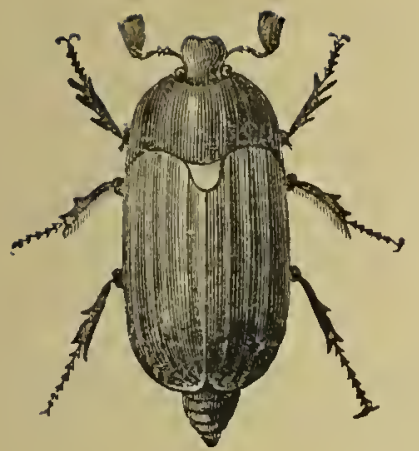

Escaravêlıo on Besonro

sustento das larras. Pela sua parte tambem o escaravêlho, cuja postura é feita vagarosamente, por espaço de dias, neeessita de comer no estado de insecto perfeito. Mas os alimentos, que então absorre, são muito diversos d'aquelles com que se nutrin quando era larra. Pois apesar d'isso, para pôr os oros, vae enterrar-se n'um sólo cheio das plantas cujas raizes são indispensareis para a nutriç̃̃o e viver da larva durante o longo periodo de tres amnos.

Esta previdencia maternal, de que se não conhece excepção, é, sem duvida, o que ha de mais bello e brilhante na historia dos insectos.

Os insectos não teen, como as ares, a faculdade de voar segundo o sen desejo, qualquer que seja a direcção do vento; logo que soprar una aragem um poneo mais fórte, elles sĩo forçados a deixal-se arrastar por ella. Mas, confiando-se á direção do vento, fazem muitas rezes longas vingens de centenares de leguas, como temos risto com os innumeraveis bandos de gafanlotos que, por vezes, teen invadillo a Europa, arrastados até nós pelos rentos do interior d'Africa.

O olfacto e a rista dos insectos são d'um admirarel descuvolvimento. Borboletas la que teem rinte e cinco mil ollos, e, em algumas moseas, a totalidarle da eabeça é invadida pelos olhos, que formam a quarta parte do corpo. Os insectos aquatiess teen os olhos dirigidos para baixo e para o alto, afim de se poderem facilmente acantelar, ao mesmo tempo, das aves que atravessam os ares e dos peixes que sulcam as aguas dos rios. Se $\mathrm{nm}$ insecto só podesse multiplicar sem nbstaculo toda a sua innmeravel deseendeneia, a terra cessaria em pouco de ser labitavel.

Felizmente que os seus oros são derorados aos millueses pelis aves, pelos reptis, pelos peixes e pelos proprius insectos carnivoros, sem os quaes o homem não poderia resistir aos 
potentes meios de ataque e destruição, de sêres que nos parecen insignificantes e pouco diguos de receio.

Mas, se em alguns encontramos inimigos terriveis, temos noutros fieis alliados cujo auxilio nos ó de incalculavel valor. Se os trombeteiros, esses terriveis insectos sugadores sahidos dos charcos, nos fazem soffrer mil martyrios, se a mosca importuma nos póde inocular o horroroso carbunculo, e se as larras de quasi todos os colcoptéros e lepidoptéros

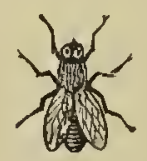

A mosea nos devoram o niellır da nossa vegetaç̃o, tambem o bomby $x$ nos dá a sèda, a abelha o mel e a cêra, a coclionilha a côr privilegiada ro manto dos cardeaes, e a cantliarida, esse sêr ardente de deslumbrante colorido, nos fornece o seu amor sob a fórma de $\mathrm{um}$ reneno terrivel de que a medicina faz hoje $u m$ uso tão salutar! E não esqueçamos tambem os insectos carniroros e 0 escaravêlho de sagrada recordação no Egypto, essa esmeralda esplendida que vire da morte, purificando-nos a terra das impuras decomposicoes com o seu incessantc e benefico traballo.

No insecto la o predominio da femea. Só isso bastava para provar a efficacia do alto papel que elle desempenla ua creação. Nas ainda ha mais. O insecto tem taubem um coração! Não é pois um sêr collocado no extremo linite da escala zoologica, mas um aninal dotado de eleradas faculdades intellectuaes, um sèr actiro, unı sèr intelligente!

Diridem-se os insectos em oito ordens a saber:

Os anoplires que vivem como parasitas no homem e outros animaes, e de que serve de typo a pulga.

Os dipténos, que se não pódem confundir com os outros insectos, por isso que teem o caracter especial de possuir duas azas, como a mosca e os rarios mosquitos.

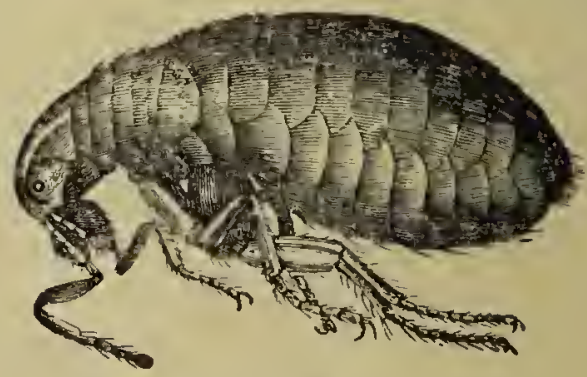

A pulga 


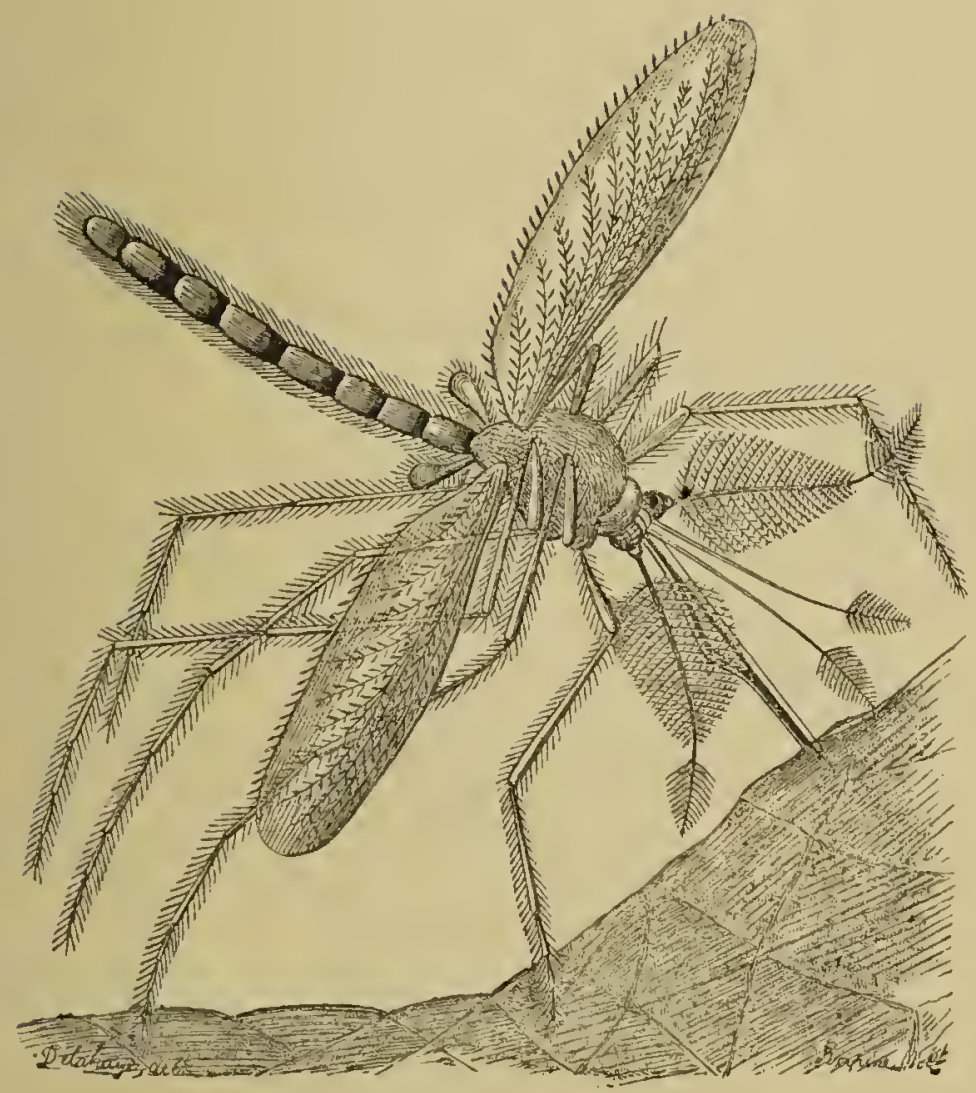

o mosquito trombeteiro

Os lepiloptéros, que sĩo, sem contradiç̧ão, os mais bellos dos inseetos, e que toda a gente eonheee sob o nome de borboletas.

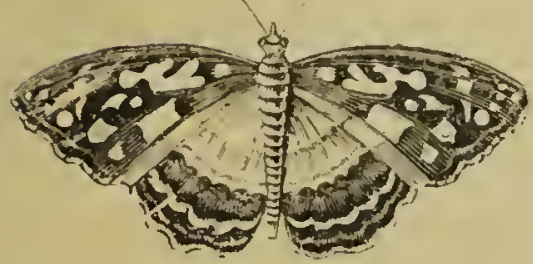

A borboleta

Os hymmenoptéros, que teem por earaeter distimetivo dous pares d'azas, sendo as inferiores menos desenrolvidas que as superiores e em parte unidas a ellas pelas extremidades. 
Pertencem a esta ordem as formigas, as respas e as abelhas.

Os nevroptéros, que, eomo os hymenoptéros, possuem dous pares d'azas, porém de risposição differente, pois, emquanto as azas dos hymenoptéros sĩo reunidas pelas extremidades, de sorte que os dous pares d'azas apenas pareeem fazer uma só, as dos nevroptéros são inteiramente distinctas e fortifieadas por solidas nervuras, origem do nome seientifieo da sua ordem. Toda a gente eonheee o mais rieo ornamento do estio, as formosas libelliuhas, essas aereas dansarinas, que se elleontram em grande numero por toda a

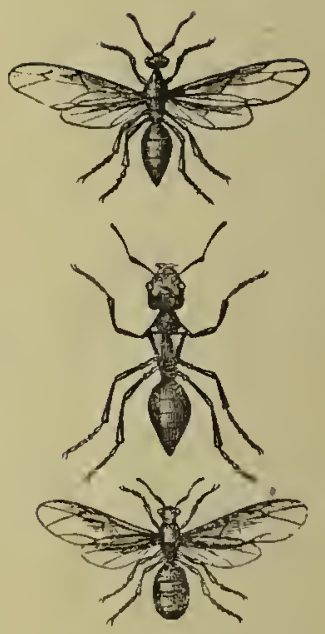

As formigas

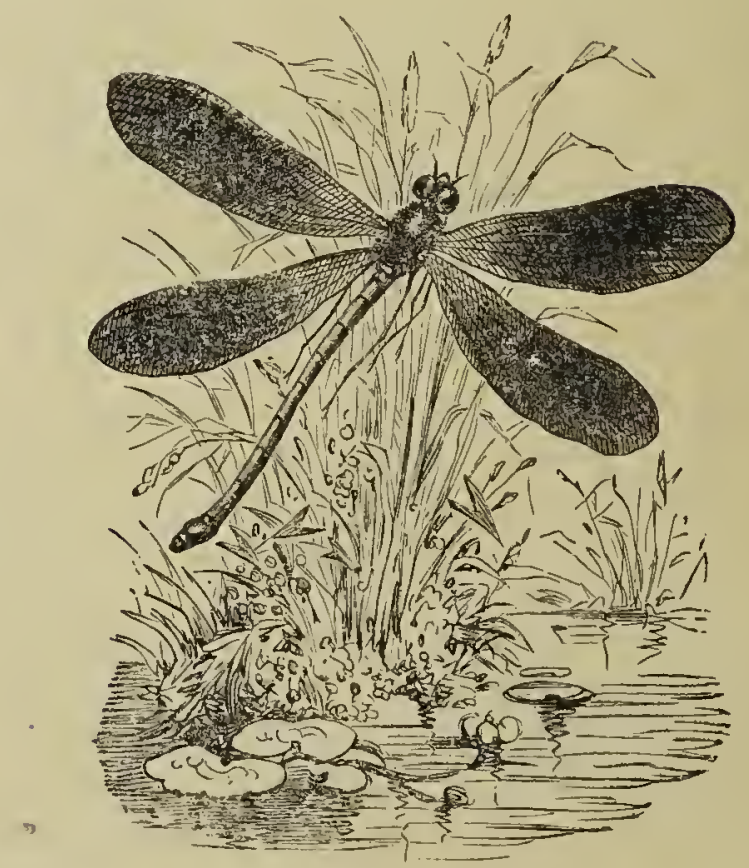

A libellinha 
parte oude ha agua doce, e a que o vulgo dá o nome do tira olhos.

Os hemiptéros, cujo nome significa semi-ulados, designnagão esta devida á curiosa e notavel particularidade de, n'um grande numero de generos e especies, sú o macho possuir azas. É nesta ordem que estão agrupados os pulgões, os perserejos, a cochonilha, os liydrometros, etc.

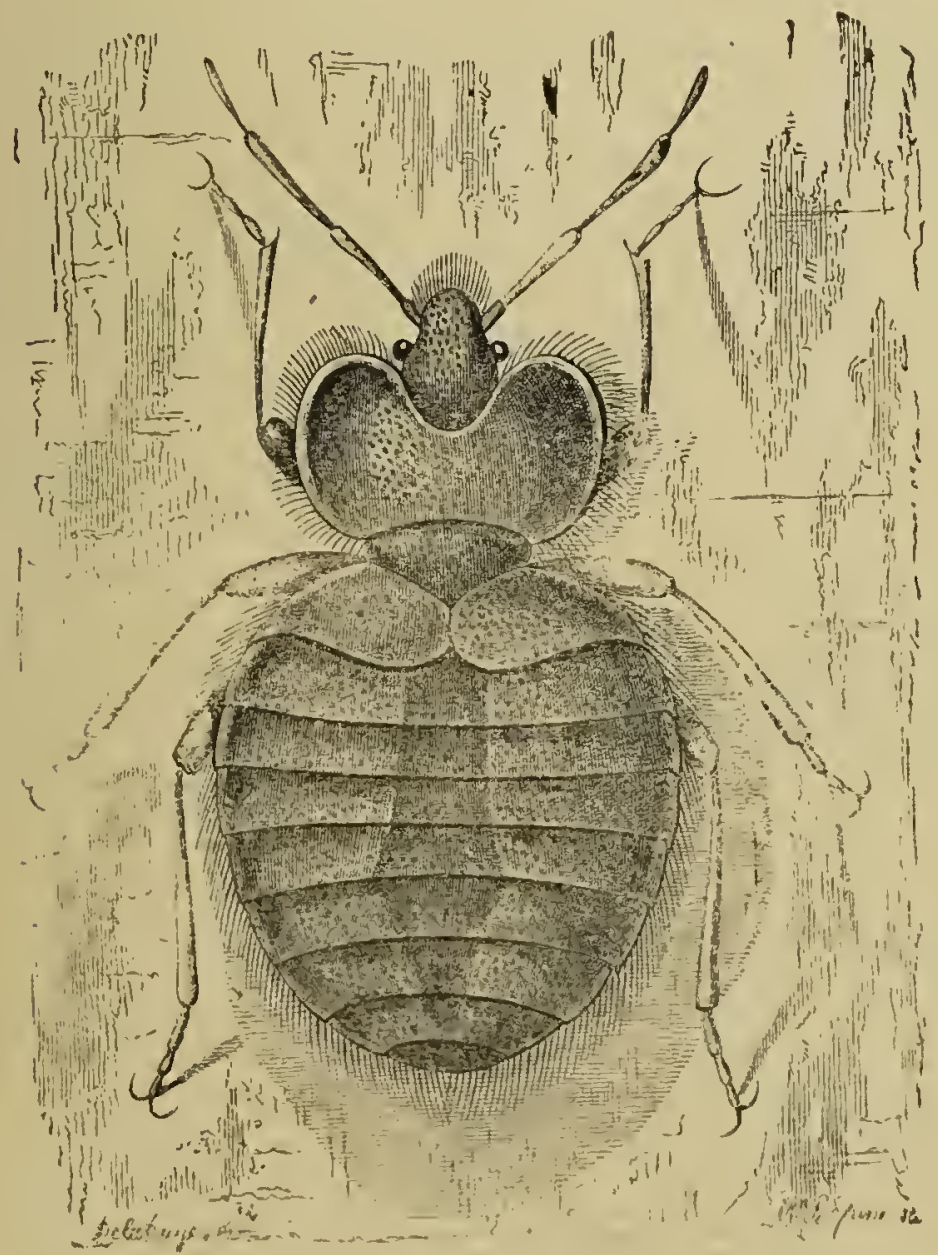

o persevejo 


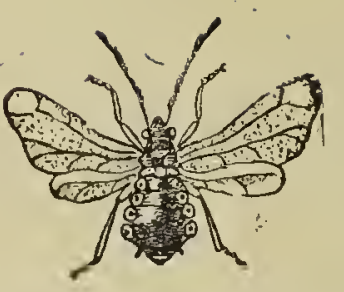

0 pulgào do pecegneiro

Os orthopléros, insectos muito activos e rorazes. Teem as azas em parte cobertas por upa substancia cornea a que os naturalistas chamam elytros. As patas trazeiras são mais longas que as dianteiras, o que os dispõe mais para o salto do que para o caminhar. Os mais notareis d'esta ordem são os ralos, os variados gafanhotos c os grillos.

Os coleoptéros compõcm a ordem mais numerosa, pois conhecem-se hoje perto de vinte e cinco mil especies distinctas. Possuem todos o caracter commum das azas serem complctanente cobertas con duas placas corneas.

Ha-os de uma belleza notarel descle a cabra loura e os escaravêlhos, tão abundantes

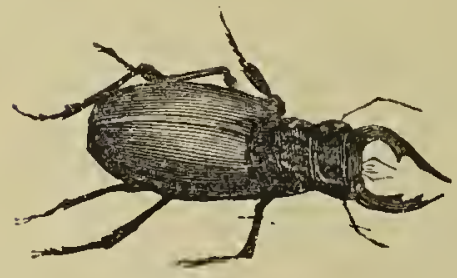

A cabra loura

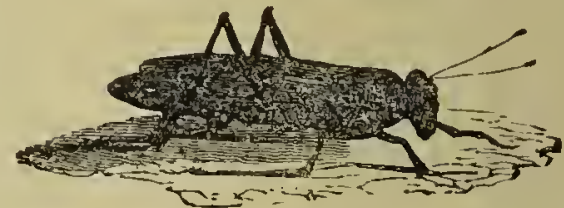

o gafanhoto nos nossos jardins, até ao pyrilampo, esse brilhante animado, cuja phosphorcscencia se faz notar nas bellas noutes de estio, illuminando as balseiras com mil fogos fatuos de arrebatador aspecto.

Os hymenoptéros, a cuja orden, como já dissemos, pertencem as abelhas, são, d'entre todos os insectos, os mais intelligentes sociareis e de organisação mais perfeita. Fazem parte dos insectos de metamorphoses completas, d'aquelles cuja maior evolução é fóra do ovo. Ás larvas desprovidas d'azas, succedem nymphas immoveis, sem alimentação externa, e por ultimo o individuo adulto. As femeas constroem o ninho, sustentam a progenie e empregam-se em todos os rariados trabalhos da colheita; os machos, esses, apenas servem para as funcções da reproducção.

Alguns hymenoptéros possuem um aguillaão communicando 
com uma glandula venenosa. Este aguilhão é, n'umas especies, apparello de defeza, n'outras serve apenas para entorpeeel as vietimas que derem servir de sustento ás larras, on para auxilial a postura. Os maehos nunea possuem ağnillıão.

Os hymenoptéros dividem-se en duas sub-ordens, liymenoptéros de abdomen sessil e hymenoptéros de ablomen pedicelludo.

Os primeiros tecm o abdomen unido ao thorax pela maior parte da base, e as larras, munidas le patas e olhos simples, vivem sob as follats dos vegetaes ou no interior das liastes. -

Os segundos tecm o abdomen unido ao thorax por um pcdicello muito estreito, ora eurto, ora bastante longo. As larvas, sahidas do ovo, imperfeitas e sem pernas, fieam inmoreis em eellulas e sĩo geralmente sustentadas pelas mães. A esta divisão, superior a todas as outras, é que pertencem as abellas.

Grande numero de hymenoptéros, e partieularmente todas as abellus, são os auxiliares eontinuos e obrigatorios da feemdação dos vegetaes, dependendo por isso a riqueza de muitas colheitas do maior numero de colmeias espalhadas pelos eampos. Introduzindo o corpo erriçado de pellos no ealix das flòres, afin de reeolher o pollen e o nectar, a abella coneentra en si o thesouro d'amor do pequeno regetal e trausporta á esposal ausente os suspiros, os desejos e os pcrfumes do amante solitario, sob a fórma do pollen que lhe vae depôr nos estigmas.

E uma sacerdotisa sublime que, diariamente, celebra mil easamentos, recebendo em troea dos seus beneficos scrviços o perfume e o mel das flôres, que docilmente line facultam o intimo sanetualio dos seus affectos.

Tambem a abcha não inutilisa a planta; sem a damuifiear, liviando-a até do excesso de produç̧ão, collue o material necessario para o sustento da larva, construção das cellulas e fabrieação do mel. ILuitos vegetaes ficariam estereis sem o auxilio das abellus. Por exemplo, cutre muitos, os que teem a corolla tubular ás avessas e pendente, o que faz com que os estames fiquem mais baixos que o pistillo. 
Não podiam estes vegetaes ser fecundados se as abellas, para attingirem os nectarios que existem na base da flôr, ao passar, não roçassem pelas antheras levando d'este modo a fecundação ao pistillo.
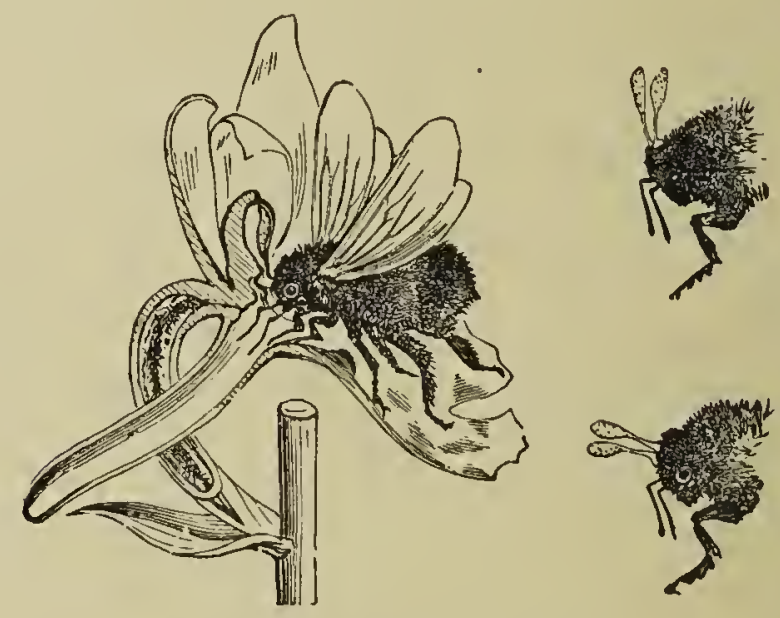

Abelhas fecundando orchideas

Algumas orchideas tambem devem ás abelhas a sua fecundação. Mas, afóra estas plantas, as abelhas augmentam a fecundação de muitas leguminosas e cruciferas, e fazem desenvolver a produç̧ão pela fecundação crusada, distribuindo indistinctamente o pollen e misturando por isso, ao mesmo tempo, as especies e os generos. 


\section{Resumo historico das descobertas sobre as abelhas - Taraldi, Swammerdan, Reammur, Schirach e Huber}

A patria do amor, a ardente Asia, que nos legou 0 cavallo arabe de rapida carreira, nos opnlenton as noutes com o suave cantico do rouxinol cnamorado, e nos den a corpo c á intelligencia mais vigor e aninação com o café ardente c o assucar doce, sinthetisou nos productos de dous insectos todas as opulencias do sen sólo privilegiado, dando á sêda, a esse tecirlo leve c impermiavel, o fogo das pedrarias mais luminosas, o nacararlo das perolas, a transparcncia do ambar e a suaridade dos mais suares arminhos, e ao mel a ambrosia dos deuses, o aroma de todas as flòres, o colorido fascinador do oiro, o balsamo que mitiga o ardor da sède, refresca, fortifica a mente abrasada pclo trabalho, e nos dá a saude, a bclleza e o rigor da mocidade.

O bombyx e a abella sĩo as duas mais prcciosas conquistas hmmanas, aquellas de que mais nos derenos orgullar, por isso quc os insectos são indomarcis por excellencia, como o prova as poncas especies que o homem até hoje tem sujeitado ao sen poder.

Mas quantos recursos não nos prestam esses a que se alcançou dar uma domesticidade relativa, c que immensa pcrspectiva de auxiliares não temos ainda a conquistar no mundo dos infinitamente pequenos!

Só hoje ó que bem se começa a estudar o insecto e a conhecer-se perfcitamente a sua estructura e o seu modo espe- 
cial de rida. Só hoje é que se the deu a importancia de que é merecedor, tratando de desviar da sua historia as fabulas disparatadas que por tanto tenipo correram como verdades indiscutireis.

Da abella, d'essc insecto curioso, conservado na domesticirlade desile os mais renotos tempos, só lá muito ponco ó que está completamente lerantado o reu que, clurante seculos, encobriu a curiosa organisação das suas republicas, que teen por base o consularlo materno, ou antes, presidencias femininas de eleição temporaria, a ignaldade do trabalho e a suppressão dos inuteis.

Os antigos da abelha só conheciam noçôes inteiramentc erradas, encobrindo a sua crassa ignorancia com aquelle apliolismo, que infelizmente ainda hoje entre nós vigora $-\dot{E}$ segredo de abellea-. Diziam isto, para significar que era impossircl desvendar os mysterios de que se cercara este curioso insecto, e conlsecer ben o seu modo de virer e de produzir. Pensaram que as abellas nasciam espontaneamente, ou que sahiam, como narra Virgilio, das entranhas dos touros inmolidos em honı dos deuses. Tambem não desdenhavam a hypothese de que as abelhas não tinham fillıos c procuravam, em algumas flôres, as sementes que deriam produzir os zangãos. Quc colhiam o mel já preparado em flòres especiaes, que só ellas conheciam, e que havia na colmeia um individuo unico, maior que os outros, a que chamaram rei, risto ser clle quem, indiscutivelmente, inuperara sobre todos os seus alados subditos. Os zangãos eram ollados como insectos estranlios associarlos ás abelhas.

E para chegarcm a estas conclusôes grandes sabios passaram annos e annos a estudar os canceirosos insectos fabricadores do mel e da cêra, a dar'se credito a Plinio, que narra, n'um dos seus livros, que um homem passon cincoenta annos a estudar as abclhas, e que outro se retirou paral o deserto para mais fructuosamente se entregar ás suas pesquizas! Acreditou-se n'estes disparates durante seculos, e talve\% ainda hoje fossem materia corrente, scm o nascimento d'um 
rerdadeiro genio, d'um martyr da seieneia, do immortal Swammerrlan. Mas antes de Swammerdan já 1 m lueidissimo espirito tinlıa previsto alguma eousa de verdadeiro. Referinı-nos a Maraldi, esse astronomo distineto que, eomo disse d'elle Fontenelle no elogio historieo, «apesar de ter passado a vida fechado no ecu, tambem não destenlava as mararilhas terrestres, redieando-se espeeialmente ao estudo das abelhas, que muito o eaptiraram .

Maralrli nos seus trabalhos publieados em 1712, distingue já tres espeeies de abelhas: as abelhas propriamente rlitas, os zangãos e o rei, apesar de já saber que esse rei era uma femeá feeunda e a mãe de todas as abellias.

Maraldi, pelo rapido exame dos orgãos sexuaes, prevê que os zangãos podiam ser maehos, mas nada deseobre relativamente ao mysterio da geração das abellas, não sabendo mesmo o papel eapital que na eolmeia desempenham as abelhas propriamente ritas, nem a que genero perteneem. Julgava-as individuos nentros, sem sexo definido! Deve-se a cste sabio a invenção das eolmeias de vidro que the permittiram esturlar o morlo de eonstrueção dos faros, postura e armazenamento do mel.

Com Swammerdan, o observalor attento, o anatomista mais profundo e perspieaz que até hoje tem existido, tudo mndou.

Swammerdan naseeu em 1637 e norreu em 1680. Era filho de 1 m botieario de Amsterdam, eolleetor enthusiasta de lisstoria natural.

A Hollanda então ela o rasto repositorio de todas as preeiosilarles da India. Os inmumeros narios, que diariamente aportivam a Ansterlan, trazim enriosos exemplares da fama asiatiea e mil variatlos artefaetos que eram ariramente eomprados pelos negoeiantes opulentos, para adomo das suas huxuosas habitacioes. A easia toda do. pae de Swammertan aehara-se repleta d'esses mil rariados objeetos, mas espalhados sem ordem, sem methodo de qualidade alguna. Swammerdan enthusiasta por temperamento pelos estudos naturaes, rledicou-se desde mui joven a elassificar as riquezas amontoadas pela paixão paterna, 
não saliindo, para isso, das salas do muzeu, senão o tempo indispensarel para comer, o que sobremodo the arruinou a saude e the deu aquella morbidez qne precocemente o arrastou ao tumulo.

O pae, querendo proporcionar-lhe $1 \mathrm{~m}$ futuro, e conscio talrez dos desgostos' que a sua paixĩo de colleccionador já lhe tinha acarretado no curso pratico da vida, obrigou-o a seguir os estudos medicos. E, n'essa phase que Swammerdan, então, invertendo o maravillıso invento de Galileu, descobre o micruscopio e aperfeiçoa-o em seguida, dando-lhe successiros augmentos con vidros de diversas curvaturas.

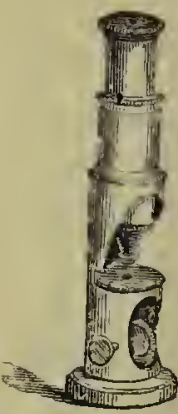

Microscopio simples

Un, deria arroubar-se na contemplação

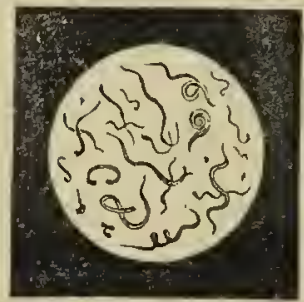

Infusorios do viuagre do infinitamente grande, abysnar-se nas maravilhas do mundo dos astros, o outro, estremecer de assombro e pasmo ao examinar os animalculos que poroam uma gotta dagua, ao contemplar os infusorios do vinagre, os monadas e os rotiferos, ao vêr a surprehendente estructura da aza do insecto, as myriadas d’olhos d'uma mosca ou as armas potentes d'uma formiga!

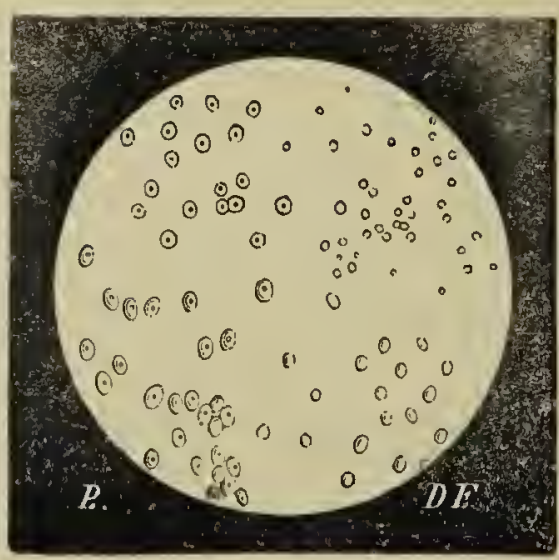

Monadas

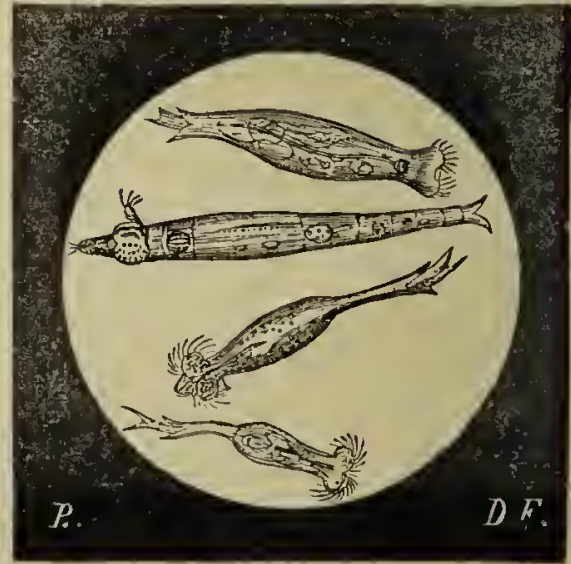

Rotiferos 
Com o auxilio do sen invento determina a metamorphose dos insectos e faz descobertas capitaes para a anatomia e physĩologia da abelha.

Cria-se, até então, que um insecto, quanło se metamorphoseara, era um corpo que se mudara n'outro, sendo portanto a larva, a nympha e a borboleta, sêres dirersos com vida propria. Swammerdan provou que a borboleta está conticla na crysalida e esta na larva, que todos são um mesmo e unico sêr,

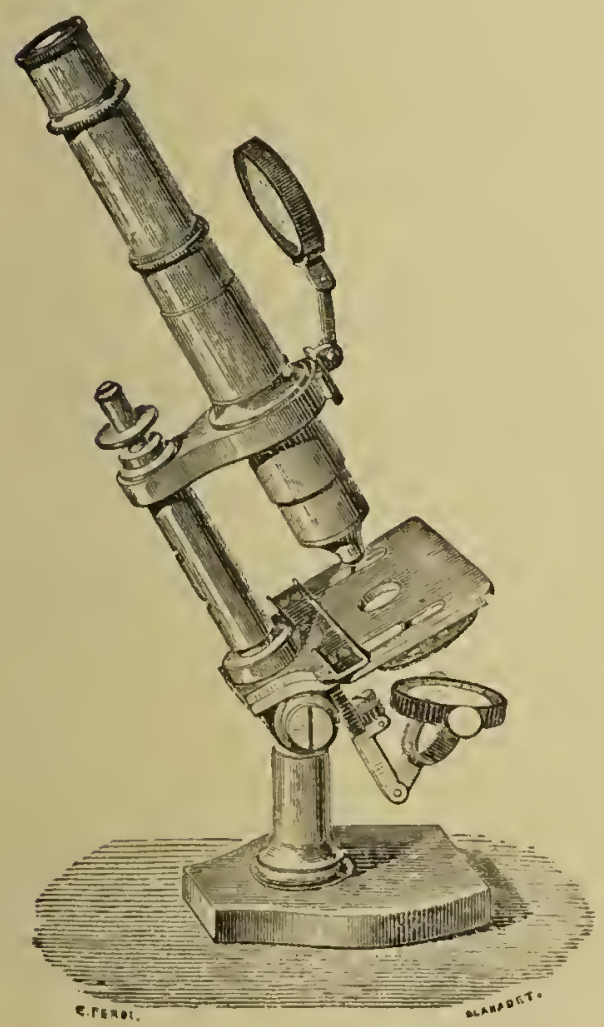

Virposcupio composto que não havia metamorplıses, mas sim uma simples evolução de orgãos que se formam, desenvolvem e manifestam. Para chegar a este admiravel resultado, não fez mais que examinar as differentes partes da nympha e da larva. Na larra descobriu não só os rudimentos das azas da borboleta mas tambem os oros que ella no futuro lavia de rir a pôr! Toltando-se em seguida parar o estudo das abellias, fa\% a anatomia da abelha mâe e cncontra-lhe un ovario chejo d'oros; estuda-lle a postura que rae de trinta a cem mil oros, e passa em seguida á anatomia dos zangãos, que descubre serem maclios. mas tropeça ante o escollo das obreiras, a que cliama neutras, julgando-as desprovilas de sexo. V'è que lia uma só femea, que as abellias obreiras é que sustentam e cuilam das larvas, que os machos nada fazem, sendo mortos após a fecundação da rainha, e que todas as abellıas, excepto os zangãos, são providas de aguilhão. 
Como the não foi possivel vêr a copulação concluc, erradamente, que o rapor dos machos é o sufficiente para fecundar as femeas.

As suas surprehendentes descobertas, fructo de um estudo insano, foram ridicularisadas e despresadas pelos praticos hollandezes, que o alcunliaram de louco, seguindo-se-llie, como consequencia, o ser cxpulso da casa paterna, visto que ao cspirito mercantil do boticario hollandez the repngnara alimentar a ociosidade do filho, que, em lugar de se apaixonar pelas trapaças do commercio licito, ousava pensar só no mundo surprchendente dos infinitamente pequenos.

De porta em porta, sobrecarregaro além d’isso com uma immcnsa colleção de preparados anatomicos, viveu Swammerdan algum tempo do auxilio de rarios amigos, até que rccolveu transportar-se a Paris, onde foi magnificamente acolhido. Mas os desgostos, as pricacões, a vida sedentaria que tinha levado, abreviaram-lhe a rida, matando-o aos quarcnta e tres annos, e obrigando-o a deixar inedita a mais admiravel das suas obras a Biblia naturae, que Boerhaave publicon em 1737, isto é, cincoenta c sete amnos depois da sua morte.

Parecc que com os elementos deixados por Swammerdan sc devia fazer em breve una completa luz nas menores particularidades referentes ao virer das abelhas.

Pois tal não aconteceu. O eminente sabio francez Reaumur, que the succedeu, consagrou os seus especiaes disvclos, n'este ponto, em certificar-se unicamente das descobertas de Swammerdan. Para, saber se existia uma sú rainha no enxame, divide um enxame em dous que colloca em colmeias distiuctas, e examina as abelhas uma por uma, encontrando apenas nma rainha n'uma das fracçoes. Para examinar as abelhas mergulhara-as $\mathrm{cm}$ agua, calculando matlematicamente o tempo para que ellas ficassem sem rigor; mas com vida, tendo a assombrosa paciencia de contar d'este morlo até vinte e sete mil abclhas. Sabido que do exame dividido, uma fracção tinha uma rainha e outra não, o que ó que succerleria? O enxame que tinha rainha continuava a trabalhar e a pro- 
gredir, emquanto o outro morria todo em poucas semanas. Logo não podia admittir duvida a conclusão de que um enxame sem rainha é um enxame perdido.

Reaumur, apesar dos dez annos de estudo que dedicon is abelhas, ponco adianton as descobertas feitas. Confirmou-as, 6 verdade, mas ainda se fez echo de erros, asseverando quc as abelhas ordinarias eram sères neutros, que a abelha mãe põe oros differentes para o nascimento de outras abelhas mães, e de rerdadeiro só anteviu que a abelha mãe necessita de uma fecundação apenas para a sua postura de milhares d'oros.

O allemão Shirach immortalisa-se pouco depois pela descoberta de que a abelha mãe não põe oros especiaes para as futuras abelhas fecundas, mas sim que as operarias, as chamadas neutras, é que gosam da faculdade de transformar um ovo qualquer em oro real, dando maior desenvolrimento á cellula e fornecendo-lhe um sustento especial, podendo, d'este modo, fazer tantas mães quantas fôrem do sen agrado. Para chegar á prora pratica d'esta rerdade, metteu em caixas separadas abelhas vulgares com cèrn, mel e faros com ovos. Estas caixas tinham orificios sufficientes para a circulação do ar, mas por onde não porliam salıir as abelhas. Estas abelhas começaram logo a trabalhar, a applicar-se a obter uma rainlıa, desenvolvendo-se e transformando-se d'estc modo em tantos enxames, cada um con a sua rainha, quantas eram as caixas onde tinham sido encerradas. Esta descoberta, que hoje está geralmente adoptada para a creação artificial das rainhas, produziu immenso ruido e soffreu a zombaria de muitos sabios d'então.

Do conlecimento de que de qualquer oro destinado a produzir uma abellia obreira se póde obter uma rainha, deria necessariamente concluir-se que as abelhas obreiras são femeas. Mas Shirach morre sem poder provar tal conclusĩo, gloria esta que estara reservarla a Huber.

Francisco Huber foi um naturalista distincto, nuna intelligencia excepcional, mas plyysicamente cego. E como pôde este homem, a quem faltara o sentido indispensavel para as variadas experiencias, vêr tão claro e fazer tantas e tão almirareis 
descobertas? Ajudarlo primeiro pelos olhos da esposa, e pelos d'um creado intelligente, Francisco Burnens, e mais tarde pelo tacto, talento superior c disposições especiaes de M. elle Jurine, a filha de um medico de Genova, que foi a sua mais assidua e intelligente collaboradora e anxiliar.

Huber uasceu em Genora em 1750. O pae era ao mesmo tempo um musico, um pintor, e $\mathrm{nm}$ esculptor distincto. 0 filho desile muito joven patenteou a sua precoce paixão pelo estudo e, quando tudo the sorria, quando ante elle se desenrolara um seductor futuro de esperancas, uma fatalidade rouba-lhe a rista aos dezesete annos de idade. Parecia que tudo estara perdido para elle, quando uma joven distincta, uma alma rerdadeiramente superior se apaixona pelo pobre cego, e, desposando-o, consagra-lhe todos os seus affectos, insufla-lhe nova rida e dá-lhe noro ardor para o trabalho em que elle se immortalisou. A esposa foi o seu secretario, a sua ledora e o seu collaborador assiduo. A dedicação d'esta senlora durou quarenta annos, deixando, pela morte, o marido mergulhado na mais angustiosa desolação.

Huber referiudo-se aos elevados dotes intellectuaes, ao amantissimo coração e á delicadeza de fórnas, que a faziam parecer uma creança, define-a assim n'um dos seus mais preciosos trabalhos «Mens meande in corpore parvo.»

Swammerdan acreditara que o simples rapor dos machos bastava para fecundar as femeas, e Shirach que as femeas se multiplicaram sem macho. Huber, duridando d'estas opinives, inicia os trabalhos conı a descoberta da fecundação das abelhas. Colloca rainhas, logo em seguida ao nascineuto, e por consequencia virgens, en colmeias onde não havia um só nacho. Já se vê que as colmeias estaram fechadas de modo que era impossivel ás rainhas o sahir e communicar com o exterior.

Todas estas rainhas ficaram estereis. Logo a fecundação da rainlia é necessaria.

Mas tornava-se preciso a experiencia eni sentido contrario. Essa fêl-a introduzinclo rainlıas virgens em colmeias cheias de machos, mas todos prisioneiros, e do mesmo modo ellas ficaram 
estereis. Evidcntemente a haver fecundação tinha de scr feita ao ar lirre, fóra da colmeia; mas como provar-se isto? D'um modo ben simples. Examinando diariamente as colmcias e a sahida das rainhas. Um dia, no mez de junho, ás onzc horas da manhã, uma rainla sahiu da colmeia seguida de torla a lcgião de machos, e, quando voltou, ao resto da tarde, trazia comsigo os signacs evirlentes da fecundação, isto é, os fragmentos dos orgão sexuaes do macho. E, d'ahi a dous dias, esta fcmea mãe comcçou logo a postura.

Prorou portanto Huber que as femeas mães precisam de fccundação, que ella se opera ao ar livre, e que, n’uma hora de amor, rccebem a maternidarle para toda a vida.

A estas succederam-sc logo novas e mais surprehendentes descobertas, das quaes a principal é a do scxo das abelhas obreiras, que até entĩo passaram por ncutras. Huber reparou que as abchlhas duma colmeia expulsaram $n 11$ dia certas companhciras, c quc esses individuos proscriptos não differiam dos cxpulsadores seño em serem um pouco mais escuros na cố do abdomen. Este caso reproduziu-se pouco tempo depois em varias outras colmeias. Huber suspeitou desde logo que estas abcllıas, a que deu o nome de abelhas negras, podiam muito bem ser verdarlciras femeas que, com a sua fecundidade, causassem inquietaça ao enxame por causa das rainhas. Havia um meio de se certificar da rerdade das suas suspeitas c esse meio cra dissecal-as. Mas onde deparar com um anatomista bastante habil e de conhecimentos precisos para trabalho tão mclindroso? Felizmente encontra em M.elle Jurine, a que já nos referimos, a sua mais potente e instruida auxiliar.

IL. elle Jurine era apaixonarla pclas sciencias naturaes, possuindo ao mesmo tempo os conlecimentos necessarios para, sob a direcção do cego perspicaz, fazer os mais rapidos e fructiferos aprovcitamentos. Entrega-se com arror á tarefia c descobrc não só nas abelhas negras dous ovarios perfeitamente distinctos, e analogos aos das rainhas, mas, estendendo as suas pesqquizas ís abellas obrciras, encontra cm todas cllas este signal caracteristico do seu sexo. Não havia pois individuos 
neutros na colmeia: só machos e femeas. D'aqui á confimação radical da descoberta de Shirach, de que o sustento c o desenvolvimento do alveolo é que transformaram o individuo sahido do oro em femea fecunda ou não fecunda, em virtude do atrophiamento dos orgãos, distara apenas um passo que foi bem depressa transposto pelas subsequentes experiencias de Huber.

Mas primeiro era preciso saber-se se haria abelhas obreiras fecuudas. Para isso enche com ellas bocetas de vidro contendo cellulas rasias; d'ahi a pouco essas cellulas possuem ovos, d'onde com o tempo sahem zangãos, mas sempre zangĩos, isto é machos e nunca femeas. Uma obreira é agarrada quando se dispunlua a depôr um ovo n'uma cellula, e M.elle Juriue, dissecando-a, encontra-lhe ovarios pequeninos, frageis, mas ovarios com oros. Havia pois abellas obreiras fecundas, c Huber nota, ao mesmo tempo, que só apparecen d'essas abellıas nas colmeias onde morreu a rainlıa mãe.

Shirach tinha descoberto que toda a larva de abelha se póde transformar pelo sustento em larva real; logo, Huber, aprovcitando csta descoberta, conclue que, tendo, por qualquer casualidade, morrido a fenea fecunda as abelhas fabricam grande quantidade de manjar real, para sustento das larras que querem transformar. Algunas parcellas d'esse manjar calıem nas cellulas proximas e as larvas, que lá habitan, ficam com uma meia fecundidade. Para verificar isto separa seis cellulas que se achavam proximas d'una cellula real, e d'estas seis cellulas sahen, com o tempo, seis obreiras, que elle faz pintar de vermelho para as poder distinguir das outras. Introduz estas obreiras n'uma colmeia onde não havia rainha e d'ahi a pouco apparecem oros, d'oude sahem zangãos. Uma abella é agarrada quando estara a pôr, e, examinada, verifica-se que é uma das vermelhas. Estara pois provado que as abelhas ordinarias eram femeas, e que essas femeas pódem ser fecundas, ponclo apenas ovos de zangãos e que só as rainhas é que gosam da faculdade de pồ ovos machos c femeas, sendo, para isso, inclispensarel seren fecundadas nos primeiros dezeseis dias após o 
nascimento, porque se passarem dos vinte só põem ovos de zangãos.

As descobertas de Huber vieram fazer uma rerolução na historia das abelhas. Os erros, que por tanto tempo correram sem discussão, foram substituidos por verdades irrefutareis, por isso que eram inteiramente baseadas na experiencia. Depois d'elle pouco mais se tem adiantado, e a luz produrida por $\mathrm{nm}$ cego illustre é a que mais completamente illumina a historia das abelhas. 


\section{Anatomia e physiologia das abelhas}

Com as descobertas de Huber determinaram-se os seguintes pontos até então obscuros. Que havia na colneia una

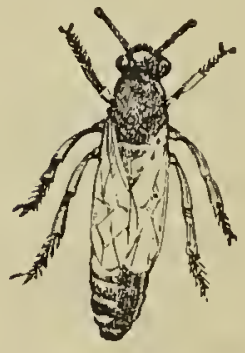

Mestra on mĩe

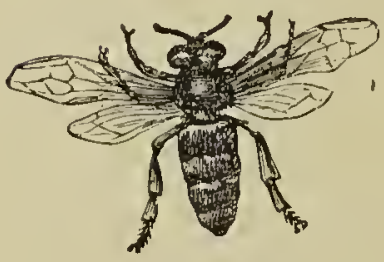

Obreira

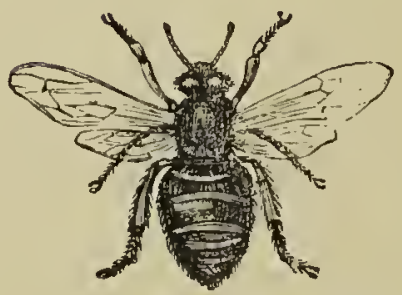

Macho ot Zangào abelha fecunda a que se podia dar o nome de rainha, nestra ou mãe commum, abellas obreiras ou femeas geralmente infecundas por atrophiamento systematico dos orgãos sexuaes, e, emfim, zangãos ou machos, servindo apenas para a fecundação da abelha mãe.

Como já dissemos, lıa nos insectos o predominio do sexo feninino, mas nos hymenopteros sociaveis ha mais alguma cousa, a dedicação das virgens que se sacrificam ao interesse commum.

0 principio social na republica das abelhas é a maternidade e a fraternidade; o soberano poder não ó dado á ma's formosa, nenı á mais fórte, mas sim á mais fecunda. 0 trabalho é distribuido segundo as forças e aptidões de cada um, e a retribuição proporcional a esse traba- 
1ho. Mas o principal papel ó representado na colmeia pelas obreiras, por essa populayão laboriosa e activa que trabahta sem descanço para o ben commum.

A obreira ó d'um pardo escuro. O corpo, composto de cabeça, thorax c abdomen, é, em parte, coberto rle pellos, a cabeça, quasi triangular, tem as antennas, os olhos, os stemattos e as peças bocacs. As antennas, a séde do olfacto e du ourido, são compostas de doze articulos. Os machos teem as antennas mais desenvolvidas, e ć por isso que correm atraz das femeas atrahiclos pelas suas cmanações.

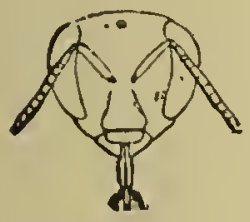

Cabeca de rainha

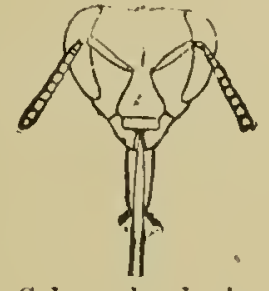

Cabeça de obreira

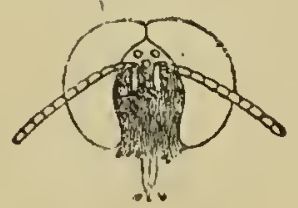

Cabeca de macho

Huber pensava que as abelhas recebiam a percepção do cheiro pela bôca e Lehmann pelos estigmas; as expericncias de Lefcbre provaram porém, á evidencia, que o orgão do olfacto cxistc nas antemns. Lefebre approximou das antennas d'uma abelha occupada a lamber assucar, uma agulha inodóra, e o insecto não fez morimento algum, mas approximando-the cm seguida uma agulha cubebida em ether, a abcha agitou as antemnas, que roltou para a agulha, dando ao mesmo tempo os mais sensireis signacs de incommodo e desagrado.

E commum tambem o rèr-se duas abelhas, quando se encontram, tocar as antennas, palparem-se e trocar entre si o santo c a senlaa. Privadas das antenuas, e portanto do ouvido e do olfacto, as abelhas não só cessam completamente de trabalhar, mas tambem não pódem orientar-se no interior da colmeia.

Os olhos immoveis, collocados dos lados da cabeça, são compostos de grande numero de ollos simples voltados para 
todos os lados, o que lhes permitte vêr em todas as direcções. Cada olho simples é composto d'uma verdadeira sclerotica e uma choroide de pigmento escuro e espesso, e são desprovidos de vasos sanguineos, cujo serviço é feito por tubos finissimos para a circulação do ar.

O modo como se opera a risão nos insectos não está sufficientemente esclarecido; mas o que se sabe é que os insectos vêem a pequena distancia, e a formação da imagem é multipla e uma por cada faceta.

Além dos olhos de facetas teem as abelhas um potente microscopio em ocellos dispostos em triangulo, de cornea muito convexa e crystallino conico. Os nerros d'estes ocellos estão ligados directamente ao cerebro; o nervo optico é largo, desenvolvido e emanando do cerebro insere-se na sclerotica, o que $6 \mathrm{um}$ dos principaes traços caracteristicos da intelligencia dos liymenoptéros.

A abertura da pharinge é cercada de peças bocaes; compõe-se de labio superior, de mandibulas curtas e espessas, sem dentes, mas unindo-se como duas colheres que se juntassem pela parte concara. A abelha, na rigorosa accepção da palavra, não suga nem clupa os liquidos das plantas, flôres ou fructos, como fazem as moscas e muitos outros insectos, lambe-os, levando-os assim á cavidade bocal. Com as mandibulas é que a abelha abre as antheras das flôres para colher o pollen, e é com ellas que amollece a cêra e tritura tambem algums regetaes.

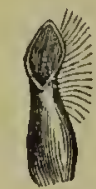

Mandilsula de obreira

A trompa, que se the segue, é constituida pclo embainhamonto do labio inferior, e servc para fazer chegar á pharinge, por pressão ondulatoria, os succos apanhados pela extremidade terminal alongada do labio inferior. Este labio está collocado na região posterior da pharinge; a base é uma peça cornea, curta, pequena e unida á hypoglotte.

A lingua nas abellıas obreiras é longa, para llıcs facilitar o accesso aos nectarios situarlos, especialmente nas flòres tubulares, nos mais reconditos recessos. 
A região média do corpo da abellha, a que se chama thorax, é formada de tres amneis unidos entre si, o prothorax, o mesothorax e o melathorax; o prothorax, on collar, é apenas uni estreito annel; o mesothorax e o metathorax são os que compōen a parte principal, onde inserem, inferiormente, os tres pares de patas e, superiormente, as azas. O mesothorax é na parte superior bastante conrexo, formando o que se clama escudo, conrexidade esta derida aos potentes musculos das azas.

A aza é um orgão especial, destinado ao vồ, e d'una resistencia que vae gradualmente decrescendo do bordo anterior ao posterior, condição esta necessaria para o rôo. As azas são primeiro umas vesiculas ou saccos achatados e nma rêde de tubos contendo as tracheas que formam as nerruras; estas tracheas, enclienrlo-se d'ar, ajudam a distender as azas quando o insecto passa ao estado adulto, e as vibrações, que se the seguem, seccam-as e tornam-as resistentes. São as nelvuras das azas uma das grandes bases para a classificaç̃̃o dos liymenoptéros.

A abelha possue quatro nervuras principaes que conieçam na base da aza e são a costal, sub-costal, a externo-media e a nerma anal, seguindo-se a transverso-media, a radial, as cubitaci e as recorrentes. Entre as nervuras, e limitadas por ellas, encontram-se cellulas importantissimas tambem para a classificação.

As azas das abelhas teen dous movimentos; o das azas grandes, de cina para baixo, sustentam o insecto no ar e fazem-o arançar, o das azas pequenas, batendo o ar que está na rectaguarda, faz arançar on recuar mais rapidamente o insecto, e dá-lhe a faculdade da direção do vôo. Arrancadas as azas pequenas ás abelhas estas ou não rôam, ou o vôo 6 fraquissinio.

As azas, pela disposição espiral das nervuras e pela conrexidade 11 a parte superior, sĩo dispostas a actuar sobre o ar, obtendo o maximo apoio e o maior deslisamento.

As abelhas pódem voar até distancia de tres kilometros, 
se bem que, geralmente, só percorram a distancia maxima de dous kilometros.

Tem havido exemplos de, arrastadas pela necessidade de sustento e falta de plantas proprias, voarem até distancias enormes, fóra de toda a expectativa. Mas os vôos longos fatigam-as, sujeitam-as a mil accidentes, fazcm-ns perder tempo, o que equivale a uma diminuição sensivel de colheita. É por isso que é muito recommendavel a plantação de todas as flôres proprias para a collıeita, nas risinhanças dos colmeaes.

Passando das azas ás patas, vemos que ellas estão implantadas no lado inferior do thorax, e que se compõem de anca, coixa, perna c tarso.

Offerece comtudo a pata posterior da abella curiosas e notabillissimas modificações. A perma é achatada e clilatada em triangulo alongado, inserindo a extremidade aguda na coixa e a larga no tarso (palleta triungular). Ha uma cavidade na parte externa, a que sc dá o nome de cesta, colhér e alforje, onde a abelha retem, por meio de pellos semelhantes a ancinlos, o pollen e o propolis. O primeiro articulo do tarso, nuito maior que os outros, $\mathrm{c}$ de fórma subrectangular (peça quadrada), implanta-se no angulo interior cla perna, e prolonga-se, exteriormente, sob a fórma d'uma pinça, que serve para desligar as. laminas de cêra, segregadas por orgãos proprios, situados no abdomen. Inferiormente á pcça quadrada estão series transversaes de pellos cylindricos parallelos, d'um

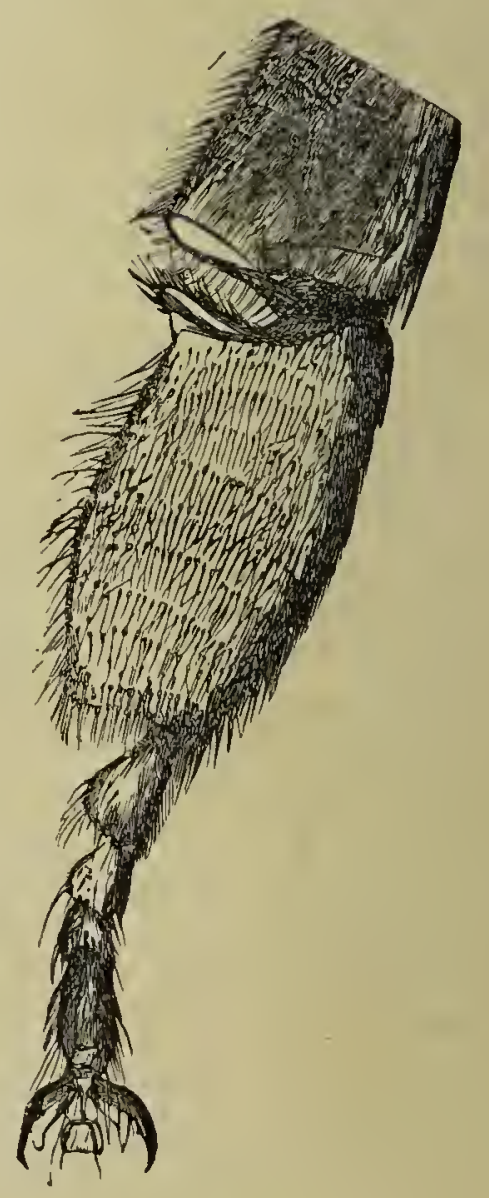

Pata da abelha 
amarello dourado, constituindo a cscoria, que serve para reter e remir o pollen das flòres, on retirar o que fica adhcrente no corpo das outras obreiras.

A parte inferior d'esta mesma pcça quadrada é lisa e offerece apenas uma depressão triangular com pellos longos e finos.

As patas do par intermedio são semclhantes ás tercciras, mas menos curtas, triangulares e sem caridade; a cscova 6 imperfeita. As pernas do primeiro par não são aclıatadas, nem triangulares, e não possuem cscova.

Na colheita a abellıa recolle o pollen e o propolis com o primeiro par de patas, que lhe serve de mãos, e transmitte-os ao segundo par que os depõe na cesta, calcando-os fortemente. Esta operação 6 feita com uma rapidez que mal se póde seguir com a vista, demandando $\mathrm{um}$ attento exame para ser perceptivel.

O abdomen cstá suspenso do thorax por um delgado pcdunculo; é composto de doze laminas escamosas, sobrepostas como as tcllas d'um tecto, e encerrando dous estomagos, um, o papo, que é onde a abellia armazcna o mel que colheu, e outro, o estomago propriamente dito, que é o laboratorio onde se faz a digestão. No abdomen encoutram-se os orgãos da respiração, figurados cxternamentc por quatorze pequenos orificios infileirados simetricamente e communicando com as trachcas, que distribucm o ar aspirado por todo organismo.

Sob os segmentos do abdomen, e cobertos pelo bordo do segmento precelente, vìem-sc quatro pares de glaudulas revestidas de mm tecido ntricular secretor, molle, d'um branco amarellado. S̃̃o as glandulas segregadoras da cêra, descobertas por Huber. Estas glandulas teem a fórma de pentagonos muito irregulares, chcios de laminas de cèra, e abertos por o lado de baixo. 


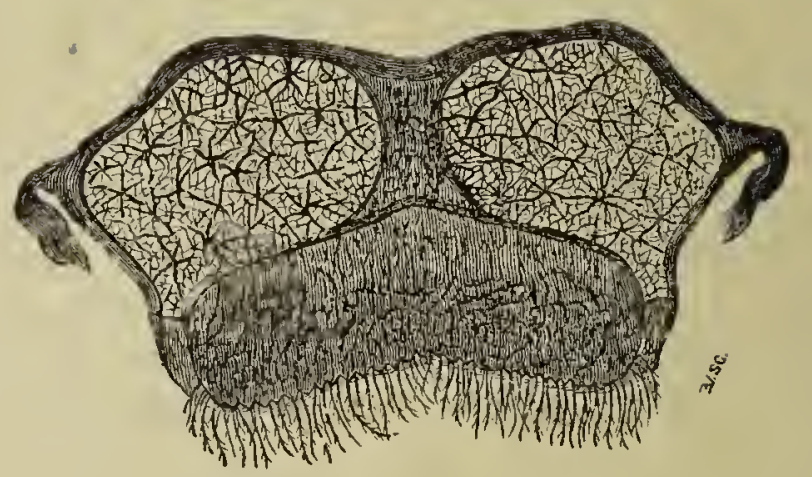

Glandula segregadora da cêra

O primeiro e o ultino segmento do abdomen são desprovidos d'estas glandulas, que não existem senão nas obreiras.

As laminas cerificas, ao salıirem das glandulas, são mais frageis e menos brancas que a cêra dos alreolos acabados de construir, e mesmo differem d'ella tratadas com certos dissolventes. A saliva da obreira morlifica um pouco a cêra, que retira das glandulas com a pinça das patas posteriores e leva em seguida á bôca, para a mastigar e tornar niais propria para o emprego que se llie quizer dar.

Passemos agora dos orgãos externos para os internos, de que vamos dar rapida descrip̧̧ão.

O apparelho digestivo da obreira é cercado de tres pares de glandulas salivares, rudimentares no macho, visto este incorrigirel mandrião, que não amassa cèra nem sustenta as larras, em nada as utilisar; tamben possuem as obreiras glandulas salivares thoracicas e cervicaes superiores e inferiores.

Estas glandulas são todas nuito grandes e desenvolvidas.

O tubo digestivo, sete rezes curvo e dobrado sobre si, está ligado por musculos ás paredes do esqueleto tegumentar, pelo lado de cima da cadeia nervosa e por baixo do raso dorsal. Nasce na bôca, atraressa o pescoço, o collar nerroso, o thorax o o peciolo, e pelletra no abdomell para formar uma vesicula que serve para reservativo elaboratorio do mel, que é depois 


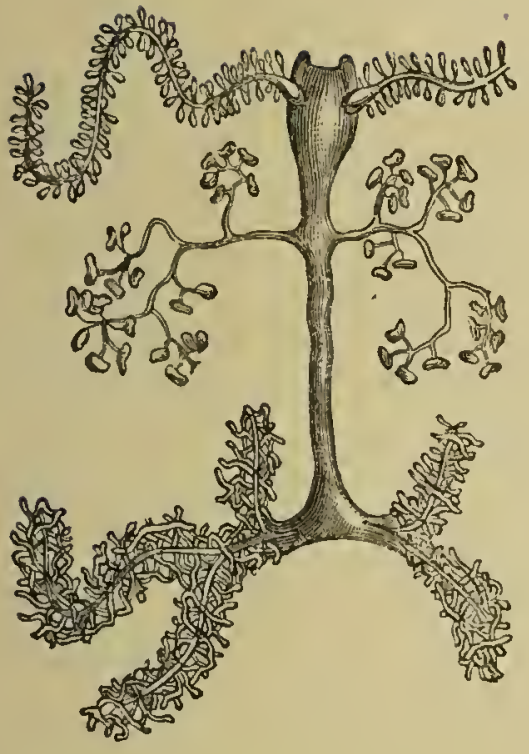

Glaudula salivar da abelha obreira

expellido nas cellulas por meio de contracçũes musculares. $O$ estomago, on intestino medio, é de circumroluções completas, apresentaudo até vinte e tres faxas bem pronunciadas e circuitado de canaes na extremidade posterior. $\mathrm{O}$ estomago dirige-se para traz do corpo, ao terço do comprimento curva-se para a direita e depois para a esquerda, seguindo-se rarias curvas até se estreitar na extremidade e formar a parte delgada do intestino terminal.

O systcma nerroso é deréras curioso. A abella, que na organisação superior é um dos insectos mais perfeitos, na organisação inferior, isto é, quando larva, está abaixo de muitas larras, de generos e especies diversas, especialmente das de todas as das borboletas.

A cabeça da abella apresenta um cerebro muito desenrolvidlo con ganglios ovaes, e largos nerros opticos. Os machos, que teem a cabeça muito maior que a das obreiras, tecm o cerebro relatiramente menor, o que explica a sua estupidez, ao passo que as obreiras sĩo dotadas d'uma grande intelligencia. Possnem taubem rarios outros ganglios d'ondle se espallam pelo corpo innumeros pares de nerros. O cmbriãn tem dezesete ganglios nerrosos abdominaes, a obreira adnlta cinco, e a rainha e os machos sómente quatro.

Os insectos superiores, a cuja ordem pertencem as abelhas, alén d'este systema nerroso central tecm mais dons systemas nerrosos reduzidos, que serrem para enviar filetes nervosos para os orgãos da digestão, circulação c respiração.

A circulação da abelláa é lacunar, sem rasos de paredes proprias, excepto uma norta anterior com un orgão impulsor 
ou coração, a que se dá o nomée de vaso dorsal, e que, pelas contracções musculares das camaras, impelle o sangue de traz para deante. O coração está no abdomen, e é formado de cinco camaras alongadas; as paredes são compostas de tres camaras e cada camara tem de cada lado da parte inferior duas aberturas. Cercam o coração cellulas pericardicas, filetes nerrosos e numerosas ramificações tracheanas; as cellulas pericardicas fazem o papel de pulmões, para a purificação do sangue.

O sangue da abelha é incolor, contendo corpusculos sólidos e sem côr, de differentes fórmas, mas com todos os caracteres de cellulas. O apparelho respiratorio, como o de todos os hymenoptéros, está espalhado pelo corpo e compõe-se de tracheas resiculares e tubulares.

Do cada lado da cavidade abdominal lia um saceo tracheano membranoso que se junta do lado externo, por meio de um collo tubular, aos cinco estigmas abdominaes, que são pequenos crificios respiratorios por onde penetra 0 ar e que 0 animal conserva á rontade abertos ou fecliados, por meio da epiglotta. Os saccos tracheanos abdominaes tecm em reserra 0 ar necessario á producção da força muscular e calor preciso para a elevação da temperatura na colmeia. Servem tambem para ajudar a propagação visto as abelhas mães serem fecundadas no ar, angmentar a resonancia do zumbido, diminuir on accelcrar o vôo segundo o peso do ar accumulado, e para resistir á asphyxia. Todos sabem quão difficil é asphyxiar um insecto e o tempo que elle póde pormanecer, sem o menor incommodo, n'um recinto privado de ar respiravel.

Os hymenoptéros e dipteros são insectos sonóros. O orgão que produz o zumbido é um veu membranoso situado entre os bordos das fendas estigmaticas e tendo na parte cxtrema uma resicula tracheana reforçadora do som.

Se collocarmos um zangão dentro d'um copo, ouvimos logo um fórte zumıbido, e, examinando as azas, apenas as vèmos tremer. Sc taparmos com cèra os estigmas o zumbido do insecto ou cessa ou se torna quasi nullo, pois o som produzido pelas azas 6 pequenissimo. 
Os iuseetos devem ter uma audição exeessivamente desenrolvida, pois não só se reconheeem pela tonalidade dos seus variarlos sons, mas tambem por elles distinguem os sexos e as especies.

As abelhas, quando ourem ao longe o trovão, fogem apressadaurente para a colmeia, prevenindo-se a tempo das consequencias da tempestade.

Este receio das abelluas pela troroada ó aproveitado pelos nossos larradores que, quando querem apanhar unı chxame fugido e não o deixar desviar-se para longc, costumam imitalcom um tambor o ruido longinquo do trovão; o enxame an primeiro som abate loggo o vôo e pousa na arvore ou habitação mais proxima.

O ultimo e prineipal apparelho que falta deserever 60 renenoso. O apparellı renenoso eompõe-se de vasos secretores communicando por meio de longos fios tubulares eom o reservatorio accumulador do rencro, que é le fórma bifurcada e tem um canal excretor que termina no dardo ou aguilhão, formalo por peças exsenciaes e peças accessórias e que cstá fixo ao corpo por museulos poderosos. As primeiras são de textura cornea e polida e occupam o eentro do systema eoustituido pelo aguilhão e gorgerete.

O aguilhão é eonposto de dous estyletes muito delgados encostados um ao outro, formando ponta acerada e tendo $\mathrm{um}$ pequeno entallıo medio por onde corre $n$ reneno. $O$ aguillıão é munido de ilentes mieroscopicos, voltados para traz, c que the impeden a rapida sahida da ferida, onde por isso, geralmente fiea, o que faz com que, na maior parte das rezes, a pobre da abella, ferindo, morra. O aguilhão da mãc ó eurro e mais longo que o da femea obreira, que é recto. O da obreira tem nove dentes e o da rainha eineo. Na base possue o aguillão duas laminas formando hastes dircrgentes, que serrem para o impellir on recoller. 


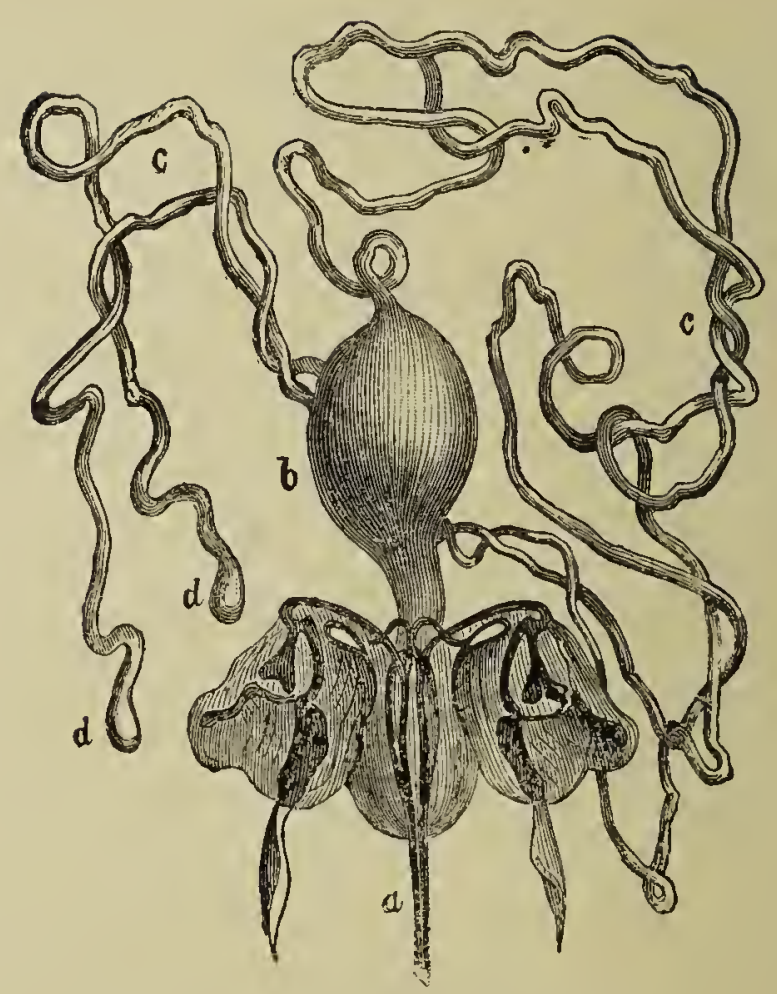

Apparelho venenoso da abelha obreira

$a$, aguilhăo $-b$, resorratorio de roneno $-c, c, d, d$, tubos segregadores do veneno

O gorgerete é constituido por uma goteira de duas valvulas unidas, envolvendo o aguilhão; a base liga-se de cada lado com uma escama ventral. A ponta é acerada e os morimentos do gorgerete e do aguilhão são quasi simultaneos, mas independentes. Primeiro sahe o gorgerete e depois o aguilhão, e ao ferir, o reservatorio do veneno abre-se e este corre pela goteira até á feridá.

*A acção do aguilhão, diz Paley, é um claro exemplo do que póde fazer a chimica ajurlada pela mechanica. A chimica prodızin 0 veneno de effeitos tão poderosos, a mechanica creon o dardo de effeitos tão complexos. Esta arma teria sido quasi inutil, sem o trabalho chimico que, no corpo da abelha, converteu o sustento em reneno, e 
por outro lado o veneno não poderia produzir effeito sem um instruinento capaz de furar e lançal-o na ferida.

Se examinarmos ao mieroseopio a lamina de 11 ma navalıa de barba, parece-nos tão rômba como as costas de uma faea, grosseira, desigual, eheia de dentes e de chanfraduras a tal ponto que parece impossivel que possa servir nesmo para eortar madeira; uma agulha mnito fina, examinara ao mieroscopio, semella uma barra de ferro sahicla da forja de $1 \mathrm{~m}$ ferreiro, emquanto que o aguilhão d'uma abellia, visto atravez o micioscopio, mostra, por todos os lados, $11 \mathrm{~m}$ polido de inna belleza maravilliosa, sem o menor defeito, a meupor fenda, a mais pequena designaldade, terminando por unia ponta finissima de que mal se deseobre a extremidade.»

O reneno da abelha é composto principalmente de acido formico misturado com outras varias substancias toxicas. Além de ser uma defesa, um meio do insecto sc libertar de numcrosos inimigos que o perseguem, tem o principal merito de servir para conservar o mel, dando-lhe aquelle sabor especial que o caracterisa.

Á medida que cada ccllula fica cheia de mel a obreira encarregada de a tapar com um operculo de cêra, antes de proceder a esta ultima operação, mergulha no liquido o agnithão, afim de misturar ao delicioso nectar uma gotta de veneno, impedindo-o assim de se corromper e estragar.

A picada da abelha póde ser mortal quando feita na parte superior do corpo; em casos d'estes são numerosos os excmplos de morte em poucas horas, pelo que convém que o principiantc acautele especialmente o pescoşo, cara e cabeça, com a mascara propria, sempre que vá proceder a qualquer trabalho nas colmeias. Referimo-nos, propositadamente, ao principiante, por isso que, para os vellos apicultores, as picadas são innoffensiras, em virtude das repetidas inoculaçóes thes darem uma especie de raceina que os torna refractarios ao veneno das abellias.

Gubler, nos Commentarios therapeuticos escreve o seguinte respeito ao reneno das abclhas:

"Se alguns dos numerosos remedios aconselhados com tanta afou- 
teza déssem bom resultado ponco lavia a recear das picadas das abelhas. A primeira coisa a fazer, ¿ retirar o aguilhão o mais depressa possivel. Quando a resicula do reneno, com os musculos que a acompanham, se deshiga da abelha juntamente com o dardo, este, que de per si penetra mais e mais profundamente na carne, injecta constantemente veneno na ferida. Se so extrac o dardo inmediatamente, a picadnra raras rezes tem conscqnencias sérias; mas, para o cxtrahir, é preciso uño o apertar cntre os dedos, por isso que, d'esta fórma, lançar-se-hia o vencno na picadmra. É prcciso raspar fórtemente com a unha, para impedir que a vesicula, que se contrahe ao contacto do ar, envie mais veneno á ferida. Quando o dardo está tirado, vão convém irritar a ferida esfregando o logar onde ella foi feita. Qnalqner que seja o prurido é preciso resistir a este desejo, por isso que, d'esta fórma, espalhar-se-hia o reneno n'uma maior parto dos tecidos, harcudo, por conscquencia, uma major inchaç̃o e um maior angmento de clòres.

É por o mesmo motivo que mun picadnra de mosquito, sc fôr esfregada algmus dias depois, ineha de novo. Como a maior parte dos remedios indicados reclamam fricçōes, são peores do que não fazer natla. Quando a pelle sía, as picalnus fazem ponco mal, por isso que o suor nentralisa o reneno, trazendo-o para fóra. Não se deve, como erroneamente aconselham alguns anctores, sugar a ferida; pótcm d'ahi resultar consequencias desagradaveis, por isso que, emquanto o veneno dos reptis, que só actua sobre a circulação, póde ser engulido impnncmente, o veneno das abchlas actua podcrosanente sobre os orgãos digestivos. Ganha-se com este acto grandes dòres de cabeça e fortes incoumodos de cstomago. Para nós a agua fresca é o melhor remedio contra a picada das abelhas; com clla o veneno dissolve-se depressa e a frescura da agua impede a inflammação. Á falta de agua fresca, póde-se esmagar algnmas plantas aquosas e applical-as sobre a ferida. Bevals recommenda o ammoniaco (alcali volatil) c diz que, en casos graves, se pólé mesmo tomar internamente. A dóse a tomar em $\mathrm{um}$ liquirlo pórle variar de cinco a vinte gottas para um adnlto, menos para uma creança, proporcionahmente á sua idade. Prodız mua transpiração abundante e neutralisa os cffeitos do veneno.»

Cowan, além do ammoniacó, aconsella contra a picada das abelhas, fricçoes de tabaco molhado, e Hamet preconisa o acido phenico, uma gotta sobre a ferida, e o laudano. Em todo o caso a agua fria e o ammoniaco parecem ser os melhores de todos e os de mais fructnoso resultado. 


\section{A mãe commum, as obreiras, e os zangãos - População e temperatura das colneias}

O papel que a abelha mãe desempenla na colmeia é unicamente do multiplicadora e mada mais; não manda, é apenas respeitada no uso das funcęões divinas, quadrando-llıe bem pouco, por isso, o titulo de rainha ou abelha mestra por que o vulgo geralmente a designa.

As obreiras, a que vulgarmente dão o nome do abellas carreteiras, acompanham-a e defendem-a como se defende uma mãe, por isso que sabom que d'ella dependo a riqueza, o desenvolvimento, o bem estar e, sobre tudo, a vida da republica. Esta mãe é excessivamente timida; ao menor signal de perigo esconde-se no mais recondito da colmeia, emquanto as obreiras arremettem furiosas a affrontar 0 inimigo. Se uma abella estranha se introduz na colmeia e a ataca ella não se defende. procurá só fugir.

Se a agarrarmos não é capaz de ferir como faz uma obreira cm circumstancias identicas: fica immovel como paralysada pelo susto. Apenas é valente para se desembaraçar das rivaes, isto é, das outras femeas fecundas prestes a saluir do alveolo. Quando duas femeas fecundas se encontram, lançan-so furiosamente 1 ma de encontro a outra, com as mandibulas procuram agarrar as azas, saltar sobre o dorso e introduzir o dardo nos ultimos anneis do abdomen, o que é a morte instantanea da mais fraca. 


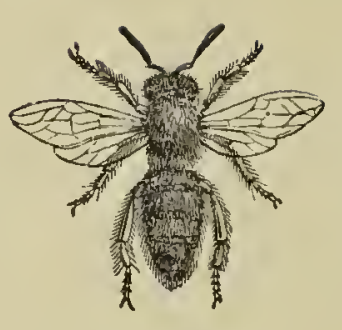

Abelha mãe da -tpis mellitica

A abellia mãe é maior que as obreiras. Tem menos caracterisadas as escovas dos tarsos, a perna do terceiro par não possue cesta, e as patas são desprovidas de pinças. As mandibulas são curtas, a trompa ó menor, as azas mais curtas que o abrlomen, o aguilhão maior e mais curvo; esta curvatura do aguilhão, que não existe nas obreiras, parece derer servir para ajudar a pustura, dando direcção ao oro.

As abellıas receben com custo una mãc cstranha; quando sc fornece alguma ao enxame, sem que este esteja para isso preparado, as obreiras agarram-a, mutilam-a e matan-a en scguida. Ás abelhas vellıas é difficil fazcr-lhes acceitar una mãc que não seja a da sua escolha, mas ás noras pódc-se conscguir isto mettendo uma mãe n'uma gaiola de teia metallica de morlo quc as obreiras the não possam chegar. Essa gaiola com a femea màe, introduz-se na colneia durante tres dias, até as obreiras se affazerem a ella.

Sem mãe as abelhas não trabalham. Entreganl-se ao desespero, migram ou morrem ell pouco tempo.

A mãe, ou ahelha mestra, nos scus primeiros dias depois de nascirla conserva-se na colmeia, mas, chegado o tcmpo quente e bello, do meio dia ás quatro horas, quando os zangãos voaul no ar em eroluções sonoras, clla sahe, e, se rolta fecundada, nunca mais procura sahir. A fecundação opera-se no ar, e uma só é bastante para toda a postura de millares d'ovos. O macho paga com a morte a felicidade de um segundo, por isso que, deixando os fragmentos dos orgãos sexuaes no corpo da femen, não sobrevive á mutilação.

As obreiras, logo que vêem entrar a femea mãe conı os cridentes signaes da fecundação, deixam-a matar as outras mães nascidas de poucos dias, cousa a que até então tinham terminantemente obstado, e d'uhi a pouco essa mãe começa a postura. 
Ha aqui a notar uma cousa. As obreiras nascidas proximo da cellula real põem oros. As femeas fecundarlas põem, a rontade e segundo a necessidade, oros de femeas ou de machos, mas as femeas virgens $e$ as rainhas não fccundadas ou relhas põen só oros de maehos. A faeullade que as femeas mães teem de pôl oros machos on femeas depende dos museulos de que está guarnecirlo o oriductı, c que, aetuando no reservatorio que contém o liquido seminal do macho, faz á vontade do insecto, ou á posição que este tem de tomar na oceasião da postura, fecundar on não os oros.

fi antigo na entomologia a reproducç̃̃o feita por femeas não fecundadas, a que se dá o nome de purthenogenese. Foi isto rescoborto no principio do seenlo XVIII no bicho da sèda e depois em rarios lepidoptéros, liymenoptéros e hemiptéros. Mas, o que é curioso, é que as fcmeas d'cstas especies nĩo fecundadas, põem oros d'onde só nascen femeas, isto é, a fóma menos perfeita, mas nas abelhas ó o inverso; as virgens só produzem machos.

A introdueção da Apis liguslica ${ }^{1}$ na Silezia, en 1853, permittiu a Dzerzon fazer curiosas experiencias a este respeito. Nos eruzamentos obserrou que uma femea

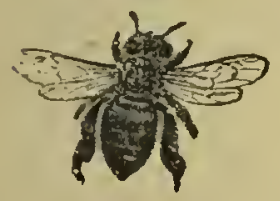

Olureira la abellua italiana

(Apris ligustica)

lignstica (abellıa italiana), que ó amarellada, unida a $n$ macho mellifica (abella europeia), que é negro, produziam minhas 0 obreiras hybridas, mas machos amarellos, isto é, ligustica puros.

Cruzando uma femea mellifica eom um macho ligusticu, as obreiras e as mães eram igualmente hybridas, mas os machos pretos e mellificas puros. Este facto, dado do mesmo modo no eruzamento com a Apis

I A Apis ligustica Spin, ó uma raça moridional muito fórto o trabathadora, mals corpulenta que a nossa abolha, que se oncontra abundantomente nas regiüos septentrionaes 10 Italia, no Tyrol, na Sulssa italiana, donde tem sido exportada para toda a linropa o parto da Asia. A femea mâo d'esta rạa tem o ablomen do um triguoiro avermolhado o as pernas de nin vermelbo intonso. Tos maclius e nas obreiras prodomina o amarello, com tons averuo. lhados. 
fasciata (abelha egypcia), e outras espocies 1, prova que os machos ficam sem pae, sendo unica e exclusiramente provenientes das femeas. A postura da mãe começa geralmente dous dias depois da fecundação. Antes de pôr os oros, a mãe percorre os faros, e, entrando de cabeça nas cellulas, examina-as intermamente; achando-as limpas de qualquer destroço, voltase, introduz o abdomen, e depõe um ovo braneo, viscoso, que fica collado no fundo pela substancia adherente de que elle está untado. Ás ve-

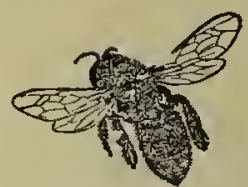

Obreira da abelha egypeia

(Apis fasciata) zes, com a precipitação, a abelha mãe deixa cahir mais que um ovo na cellula; mas, após ella, seguem as obreiras, que lhe vigiam o trabalho, limpando a cellula dos ovos excedentes, dei-

1 A Apis fasciata Latr., ou abelha egypeia ó indigena do Egypto o da Arabia $\theta$ do Ifimalaia até á China. Foi importada em 1864 na Allemanha, em 1868 em Inglaterra $\theta$ em 1873 em França.

E de un triguoiro anegrado com as nervuras das azas armivadas; o escudo do thorax é do uın amarollo avermelhado assin como os primeiros sogmentos do abdomen. Maurice Girard dá d'ella a seguinto e curiosa noticia: «A Apis fasciata foi domenticada no Egypto desie as epochas mais remotas. As colmeias eran trausportadas em bareos poio Nilo acima, por isso que, ficando o Alto Egypto dosembaraçado mais cedo da inundaçăo, o dosenvolvinento das plantas melliferas era alli muito mais precoce. Tornavam a trazer as colmeias aos propriotarios do Baixo Erypto no principio de fevereiro, $\theta$ as do Alto Egypto, que pormaneciam nos mesmos barcos, ficavam em face dos pastos visinhos do mar, regressando, só em abril, cheias de mél. Identicos trausportos ainda hojo se fazeın no Nilo.

«Os barqueiros páram cada dia nos logares onde vêem maior abundancia de flòres; Niebuhr diz ter encontrado no Nilo, entre o Cairo o Damiota, um comboio de quatro uil colmeias.

*Hojo os Arabes agricultores ou follahs, sĩo os unicos quo possuem abelhas, principalmente no Alto Eyypto.

"As colmeias são çlindros de barro fabricados com lodo do Nilo, tendo approximadamente $0 \mathrm{~m}, 40$ de diametro por 1 metro de comprido e fechados, em cada extremidade, por um disco da mesma materia, em um dos quaes la uma ontrada muito pequena proporcionada an tamanho da A. fasciata. Os cylindros são dispostos horisontalmente á sombra das arvores. A plauta favorita d'esta abolha é o trevo do Egypto (Trifolium Alcxandrium).

A Apis fasciata é muito mansa no seu paiz do origem, pelo que as manipulaşões apicolas são alli feitas sem mascara. No Alto Egypto a eluxamagem tem logar om fevoreiro, $\theta$ en março no Baixo Esyzpto; năo se conheco a enxamagem artificial nem a calottagen. No verão as colmoias săo guardadas por creanças para afugentaren os Besouros ou Vespõos. Para obrigarem as abolhas a fazer os favos perpondicularmento no eixo dos cylindros, dispõem parallelamente a este e ao sou comprinento, um pequeno pau fendido, e como isca, pedaços de favos velhos. Cortos follahs sorvem-se tambem de lavos em parte moveis, tornando parallolos nos favos inseridos os fabricados de novo, afien do facilitar a extraçăo do mol. 
xando apenas um só enı eada cellula. A mãe põe durante os mezes quentes e só cessa a postura no inverno. A maior postura é na primavera, epocha em que ha muitas flores, e portanto muito mel, d'onde se deprehende o haver, com o excesso de sustento, un excesso de postnra.

Os maclios e as femeas são produzidas segundo as neeessidlades da eolmeia, mas os oros das obreiras sño sempre os primeiros postos, pois a republica neeessita, antes de mais nada, de membros activos e laboriosos; os ociosos, os zangãos, virão depois.

Se a colmeia está muito numerosa, se existe um excesso de obreiras reclamando uma emigração, ha entĩo a postura de femeas mães, o que deixa de dar-se no easo de fraqueza.

* O vallo do Nilo estanlo perfoitancuto isolidu, a Apis foscuta guardou alli toda a sua pureza. E provavel que ella soja uma das raças yno se oncontrau na syria o na Palostina, ondo rive nus tioneos das arvoles o fendas dos rocholus. Fra talvez ella qno dava, no desorto, " mel solvagou a Sansão, ans prophetas, $\theta$ a S. Joâo Baptista. A possililidale de neclinar a fuscicta om Berlim resultou de uma comparacăn do climas. 0 periodo le grande actividide d'esta abelha no Egypto tom logar nos mezes do janoiro, foveroiro o março; ora na Allemanla a gramlo prodıçào do mol tom logar om maí, juılıo o julho, cuja tomperatura é sousivoluente a mosmir que a dos mozes do inverno no Erypto. Tem-so visto na Allouanlua, ostas abelhas, cm pleno vio, ans primoirus caloros primavoris, sahindo om massa ta colmeir, cono formigrs, quando ainda as nossas abolhis negras ostão hibernando. São muito valontos, do voo mais fúrto quo as mellifica o ligusticn fazculu ainda colhoita em novombro, o q110 rarits vezes acontoce com as noksas.

- As rainhas da d. fascirla correm muito, omquanto quo una mão europcia ou italiana cauiuha lenta o pesidauchto. Nos grandes caloros do vorio a A. fascuila fica inactiva na Allomanla assim como no bigspto; con effoito toda a espocio de abella cossa do traballar $\theta$ fica immovel quando a tomperatnm interior da colmoia attingir $36^{\circ}$ cont.; so, entīo, ellas traballassom, dusenvolvorian calor, angmostarian a tomperalura o os faros de cira aublloceriau o cahirian dorretidus no funte da colueia.

* A L. fasciala supporta os infortus na colmeia, da mosma fórma gne as nutras abolbas, em polotas, no contro dils quaes a tomperatura ó sempre do +90 ou $+10^{\circ}$. Quanto mais o frio angmentar tanto mais alimonto cousomon accelorando a respiragão. *

Lu facto curioso quo ton obstako á larga lirulgaçio da Ajis fosciala ua Europa, 60 sen caracter riolonto o intratavol, entro nós, polo yno as oporaços apicolas com olla exigom (1) unis meticuloso cuildado.

A mansilăo no Esspto tranffurma-so om vordideira ferocilado na Turopa!

Alem da mellifin, lignstica o fasciatr conhocom-so mais as soguiutes abelhas: A. Alansoni Latr., do Senoral, a 1. uniwolur Latr, do Matagascar, A. caffra o A. scutpluta l.ep. St.

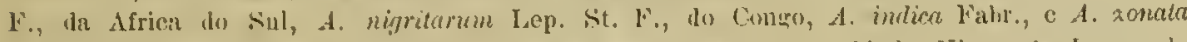
Perez, da India, A. dorsata Fitbr., A. nisgripentis Latr., e A. bicolor Klug., do Java 0 do Japato, A. sucialis Litr., da China, -1. Ieroni Littr., do Timor, O .1. rufesecns, da Tasmania. " 
Uma mãe vigorosa póde pôr tres mil ovos por dia, sessenta mil por mez, trezentos mil por anno, e um milhão, approximadamentc, nos cinco annos da sua existencia.

Esta excessiva postura é nccessaria para contrabalançar a perda das obreiras, que se calcula em trezentas por dia; d'ella é que depende a sorte da sociedadc, pois, se não fosse assim, a colmeia estara em pouco tempo descrta.

Os ovos, a quc o vulgo dá o nome de vareja, desenvolvem-se em virtude do calor da colmeia, que não desce nunca abaixo de $33^{\circ}$ centigrados, podendo-se elevar até $36^{\circ}$ cent. Logo que a larra, ou pulo na linguagem popular, apparece, o que acontece no decimo terceiro dia, é diariamente sustentada com unra mistura de mel, pollen e agua, fornecida pelaś obreiras. Esta mistura é, nos primeiros dias, branca c insipida, mas, á medida que a larva cresce, as obreiras rão-a mudando, augmentando-lhe cada vez nrais as quantidades assucaradas. A larra assimila de tal modo a nutrição que

Larva da Apis mellifica nunca se lhe encontra na cellula a menor particula excrementicia.

Logo que as larvas, que ao principio são ovaes, molles e d'um branco pardo, soffreram dirersas mudas e chegaram ao termo do seu desenrolvimento, as obreiras cessam de lhe dar a papa e fccham as cellulas com $\mathrm{nm}$ operculo de cêra um pouco arqueado, differindo n'isto do que cobrc as cellulas do mel, que ć chato.

A larva fia então, dentro da cellula, uma especie de casulo $\mathrm{cm}$ que se envolve. No fim de trinta e seis horas para a obreira, e vinte e quatro para a mãe, que é o tempo que lhes leva a fiar o casulo, a larra repousa dous ou Nympha tres dias e, findos elles, roe o operculo e apparece no estado de insecto perfeito. A duração de toda a plrase evolutira ć, para a mãe, de quinze a dezeseis dias, para a obreira, de vinte a vinte e um, e, para os machos, de vintc e quatro. 


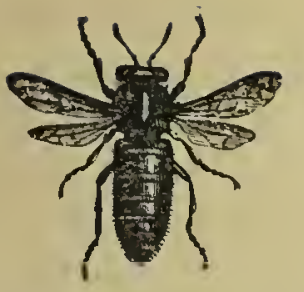

Obreira da abelha europeia (Apris mellifica)

Como a obreira sahe do casulo completamente molhada. pousa n'um favo, sendo então cercada pelas tias manas que lhe dão mel e a ajurlam a limpar e a enxugar. Soffie então uma espeeie de exame. Se é defeituosa é logo sacrificarla, mas, se se apresenta robusta e bem conformada para as diarias lides, é recebida com alegria, acariciada pelas companheiras e, em ponco, aprende a cantar aquelle sublime hymno do nosso Castillıo:

'Trabalhar', mens irmãos, que o trabalho

É riqueza, é virtule, é vigor...

Se as obreiras essas rirgens estereis, sóbrias e laboriosas sĩo o jdeal do traballıo e da dedieação, os maelıos, os zangãos pareeem ser o do oeioso, que se estende eommodamente ao sol a fazer a digestão das pantagruelicas refeições, cantando ineessantemente para afugental o tedio eausado por aquelle viver inutil.

Segundo a opinião mais geral, os zangãos só sabem eantar, eoner e dornil. Sño elles maiores do que as obreiras, mas menores que as femeas mães. A cabeça é grande e eireular, derido isto ao exerssivo desenvolvimento dos olhos. As antennas compõenı-se de doze artieulos, as patas são negrras e pelludas, sem pinças nem cestas para a apanha do pollen, o abdomen, obtuso na extremidade, 6 desprovido de agnilhĩo e eoberto de

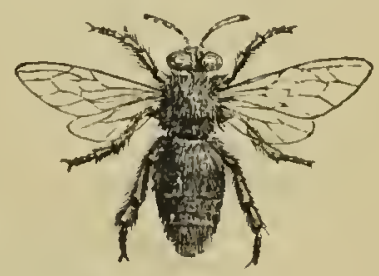

Mrelso on zangão da spis mellifica grossos pellos. Não teem tambem trompa para reeolher o mel das flôres, nem glandulas para segregar a ec̀ra.

Operada a fecundação da femea mãe, que, como já dissemos, é realisada en pleno ar lirre, pois dentro da colmeia os maehos, por mais numerosos que sejam, não importunam nunca 
a abelha mestra, teem desempenhado os zangãos o seu mais ralioso e importantc papel.

D'ahi para o futuro parecem ser membros inuteis, que só servem para consumir uma importante parte das provisũes amontoalas para o inscrno, pois cada um derora diariamente a colheita de quatro obreiras.

Demais é causa de constante magua para as laboriosas operarias, quando recolhem do trabalho fatigador, rerem os ociosos n’um dulce fur niente á porta da colmeia. Isto desgosta-as, fal-as ollar com desprezo e odio para os radios, até que um dia reunem consello, proclama-se a guerra civil e a necessidade da suppressão dos inuteis; e os machos, que 1 ão são trucidados, são expulsos para longe da colmeia e condemuados ao supplicio de Ugolino, visto não serem aptos para angariar o diario sustento.

Frequentemente, quando o alimento é em demasia, as obreiras consentem os parasitas; ontras vezes expulsam-os e cm seguida tornam a admittil-os. É porque á fome succedeu a abundancia.

As obreiras a quem morreu a fenca mãe conservam os machos durante o inverno. Portanto uma colmeia que conservar os machos quando nas outras todas elles foram destruidos, é signal de que está orphã, de que the morreu a mãe, não deixando creação em estado de poder dar nova fcmea fecunda. É preciso acudir-lhe fornecendo-llie faros com oros e creação nova, que as obreiras possam transformar en rainhas, ou cntĩo juntal-as a outra colmeia.

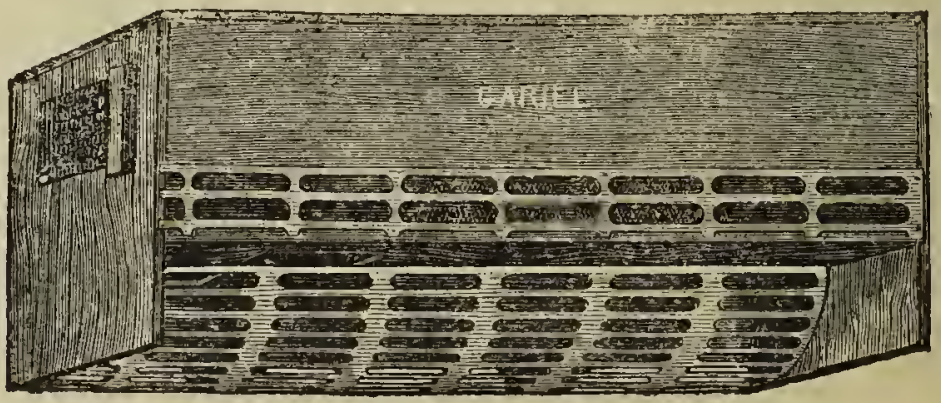

Armadilia para apanhar os zangàos 
Póde-se proeeder artificialmente á suppressão dos machos, agarrando-os em pequenas armadilhas e matando-os no fim do dia, ou collocando laminas de zinco furado á entrada da eolmeia, cujas aberturas permittem o accesso ás obreiras, que são pequenas e magras, e não aos maclıos que são mais corpulentos e gordos.

Mas isto é de pequena importancia e pouco empregado, pois, eomo já dissemos, as obrciras sabem, sem compaixão, desfazer-se d'elles quando assim lhes é preciso, e ineonmorlam-se muito eom us obstaeulos que lhes não permittem facil aeeesso. á colmeia.

Nem todos os auctores são eoncordes porém relatiramente a inutilidade dos zangĩos depois da fecundação da femea mãe. Frarière, no seu Traité de l'Educalion des Abeilles escreve o seguinte respeito aos zangãos:

"Sabe-se hoje que todas as abelhas obreiras sĩo do sexo feminino e que todas possuem ovarios; em virtude de un atrophiamento propositado estes ovarios nĩo tiveram o desenrolvimento necessario para produzir oros; mas, póle-se voncluir d'isto, que, como se tem acreditado ate hoje, ellas sio insensiveis ao sentimento d'amor eommun a todas as ereaturas? As observaçoes que pule fazer eontradizem eompletanente esta opiniĩo, e considero certo que, na epoeha em que sc vê $u$ tho graude numero de machos, as obreiras, na maior parte pelo menos, copulam com elles, em pleno ar, apesar a espeeial disposiçio orginica das obreiras tormar esta copnla eompletamente inutil. Śó depois que estas viagens aereas cessaran é que as obreiras experimentam a neessidacle de se desfazercm de sères, que, para ellas, já não teem attractiros; é então que ellas se atiram, com furor', sobre tudo quanto é do sexo proseripto, mesmo sobre as larvas, nymplas e até oros que devem prodızir zaugãos.

Um intelligente apicultor do Uruguay, o snr. E. Parod, eommunieava, não la muito, ao Apiculleur; as suas seguintes obserrações sobre o papel los machos nas colmcias:

"Eu considerava os zangios, eomo muitos apicultores, simples eomedores de mel, que, fúra da sua principal funç̧ìo, nào servian para mais nada; a pratica, auxiliada pela obscrvação, provon-me porém. 
o contrario. Possuindo umas poncas de colmeias approximadamente com a mesma população e força, dividi-as em dnas metades. Na primeira metacle colloquei ratoeiras para caçar zangãos, e a ontra deixei-a completamente livre; a balauça da collheita inclinou-se fórtemente para o lado d'esta ultima, com notavel differença. Além l'isto vi, em uma colmeia ridrada pelos quatro lallos, não uma só re\%, mas muitas, os zangãos, na mesma posição que as obreilas, todos no mesmo sentido fazenido a mesma manobra com as patas solre o mel operculado. D'onde concluo, que não serve para consa alguma, pelo menos n'esta região, supprimir os machos, por isso que cada insecto a men rêr, desempenha o papel que the foi estabelecido por Dens na natureza. Demais a collocaço de armadilhas para a apanha de zangãos á entrada das colmeias, é $11 m$ obstaculo (esagradabilissimo para as obreiras.»

Para Olivier des Serres os zangãos desempenham o papel de abelhas chocadeiras, em virtude do grande calor que possuem no corpo ser muito superior ao das obreiras.

Apesar de os termos risto repetilas vezes nos faros de criação juutamente com as obreiras, não nos parece que desempenhem o mesmo papel que ellas, pois os machos só vivem n'uma epocha do anıo em que o calor é pouco preciso nas colmeias.

Parece tambem que, na força do calor, auxiliam as obreiras na tarefa da rentilação; n’isto não fazem mais do que, em proveito proprio, dar á habitação commum uma temperatura mais agradarel e evitar que, com um clemasiado aquecimento da colmeia, a cêra dos alveolos comece a derreter, perdendo-se o miel já armazenado.

O que é inquestionavel é que, como diz Derosne, a surprehendente multiplicidare dos machos serve para mostrar a profusão immoderada com que a natureza accumula os germens para assegurar a conservação das especies. E como a fecundação da femea mãe 6 feita no ar, ć importante que possa encontrar, de prompto, un macho que a fecunde, por isso que, sendo maior que as obreiras e de rôo mais pesado, se fosse obrigada a sahir muitas vezes, estava mais sujeita a ser apanliada pclas aves insectivoras ou morta por qualquer ventania fórte. 
O peso das abelhas varía com os mezes, com a alimentação, a qualidade dos terrenos, e mesmo eom qualquer pequena influeneia local; mas a média mais geral ć que, cada dez mil abelhas, pesam um kilo, e eada dez mil pequenas eellulas de obreiras pódem conter quatro kilos de mel. T'res mil e cem abelhas medem approximadamente un litro.

Em boas estações, quando ha muitas flòres. dez mil abelhas eolhem, nor viagem, trinta grammas de mel. Caleulando seis viagens por dia, um enxame de dez mil abelhas póde eolher quatro mil e quinhentas grammas de mel n'um dia. Em paizes muito abunclantes cm flòres, ha eolmeias fórtes que chegam a eolher diariamente de tres a dez kilos de mel, mas isto é rarissimo. Se o anno correr man pódlem não eollier o necessario para o sustento do inverno, e ser entĩo preeiso sustental-as durante elle a mel on assuear reduzido a xarope, assumpto este de que nos oecnparemos en capitulo especial. N'essa oecasião, levadas pcla fome, devoram fruetos e substancias completamente inadaptaveis ás suas funeçôes digestivas.

Se se tirar o mel dos faros por meio do extraetor, operação de que tratarcmos em tempo opnortuno, fornecendo outra vez os faros vasios ás abelhas, estas produzem rapidamente mais, por isso que, não necessitandó de gastar o tempo a armazenar cc̀ra e eonstruir novas eellulas, dedicam-se cêdo á apanka do mel, aproveitando para esse fin o tempo que deviam empregar na celificação dos reservatorios.

E quasi impossivel calcular os habitantes de uma colmeia. Naseeudo oitocentas e cineoenta obreiras por deeimetro quadrado de faro, eomprelicndidas as duas faees, póde haver n'uma boa colmeia morel de eineoenta a oitenta mil obreiras e dons a tres mil zangãos; mas isto é simplesmente approximado.

A maxima população de um eortiço, - de um dos nossos antiquados corticos - e de oito a quinze mil abelhas. A femca mãe começa a pôr cm janeiro termiuando a postura em outubro. A maior postura é porém na primavera, em que põe tres mil oros por dia, 
Eis, segundo o dr. A. Dubini, o tempo que as femeas mães, obreiras, e machos, levam a desenvolver-se:

\begin{tabular}{|c|c|c|c|c|c|}
\hline & & & Мลัo & Obreira & Nacho \\
\hline Oro : . . . & & rias & 3 & 3 & \\
\hline Crescimento da larva. . & . & $»$ & 5 & 6 & $6^{\circ}$ \\
\hline Fiação do casulo . . & . & * & 1 & 2 & \\
\hline o de repouso . . . . & . & ” & 2 & 2 & 3 \\
\hline Metamorphose em chrysallida & . & » & 1 & 1 & 1 \\
\hline uração do sell aperfeicoamento & & $»$ & 3 & 7 & 9 \\
\hline$r_{C}$ & & & 15 & 21 & 24 \\
\hline
\end{tabular}

Como a visão das abelhas é prineipalmente diurna, ellas não salıem da colmeia durante a noute, mas nem por isso descançan, trabalhando incessanteniente na construcção das cellulas e armazenamento do mel.

As abethas beben agua para diluir a papa que dão á creação e para liquifazer o mel antigo crystallisado nas cellulas. De rerão colhem a agua nas fontes e regatos, e, de inverno, servem-se do vapor d'agua que sempre la na eolmeia.

Na colmeia reina uma primavera perpetua, o que é indispensavel para a vida das abelhas; se a temperatura baixa, ficam inactiras, incapazes de trabalho algum, accumulam-se unıs de encontro ás outras n'um pequeno espaço e assim desenvolvem ealor. Se porém houver calor em demasia, estabelecen rentiladores, isto é, colloeam pela eolmeia além, desde a abertura, filas de obreiras, agitando incessantemente as azas, conı uma rapidez rertiginosa.

A temperatura d'uma abellia isolada eleva-se sempre aeima da atmosphera. O thorax está tambem a nuaior temperatura do que o abdomen, por causa da energica respiração necessaria para os movimentos que dão o vôo. É lei geral para os insectos clotados de loconoção aerea, a eoncentração do calor no thorax, n'una intensidarle proporcional á potencia effeetiva do rôo. 


\section{A irritabilidade das abelhas}

f́ variavel a irritabilidade das abellhas. Muitas pessoas passam por diante de colmeaes, chegam mesmo a tocar em colmcias, sem screm atacadas, emquanto que a outras e-the mesmo difficil passar a larga distancia d'ellas sem serem picadas. A cxplicaçĩo d'estes factos apenas se póde attribuir á enorme variedacle de emanaçoes corporeas, pois não ha outro, para nós, mais plausirel.

As abellıa são sociareis en extremo, mas é preciso approximarmo-nos sem ruido, sem gritos, nem grandes movimenlos, para as não atemorizarmos. Se pousam deremos fazel-as roar soprando e não com movimentos precipitados, o que, atemorizando-as, as obrigaria a picar.

'lodo o animal se dóma e subjuga com carinhos e doçura. Se bem que seja un prejnizo o dizcr-se que as abelhas conhecem as pessoas de casa. sĩo ellas comtudo susceptiveis do uma semi-domesticidadc. Se cobrirmos as mãos $\mathrm{com}$ mol ellas rem-no lamber, sem nos cansarem o menor mal, e, quando estão uccupadas a collher o mel das flôres, porlemos andar proximo d'ellas, afugental-as, sem que se lembrem de atacar. Iras, como todos os insectos do genero, proximo do ninlio, para defenrler a prolc, atacam furiosamente ao minimo signal de perigo.

A abella, quando estí completamente abarrotada de mel, ó inoffensira, risto então ser-lhe impossirel fazer sahir o 


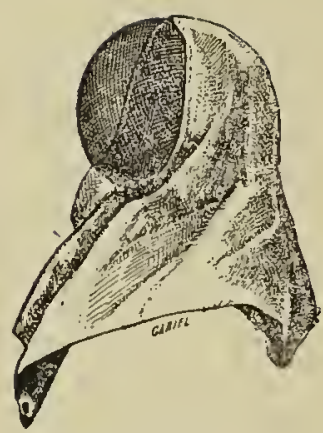

Hascara de rêle metallica

dardo do abdomen; mas, fóra d'este caso, não é prudente irrital-a.

Para evitar picadas, mais ou mellos prejudiciaes, e sempre desagradaveis, é conveniente usar-se, em todos os trabalhos apicolas, de mascara e luvas. Ein gravura aprescntamos o modelo das duas melhores e mais simples mascaras, uma conposta de uma rède metallica gramecida dc panno, para nsar sem chapeu, c outra consistindo em um reu de tule branco e tule negro na frente, com elastico, que se adapta ao chipeu, e de umas luvas de algodão, duplas, scndo as superiores muito finas, tapadas e lisas, e as inferiores mais grossas e de tecido raro, luvas que resguardam, melhor que as de pellica, e permittcm maior liberdade de morimentos.

Assim, embora a abella pique na luva, o ferrão não chega á pelle, ficando na espessura do tecido; com estas luras de algodão tem-se completa facilidade de movimentos, o que não acontece

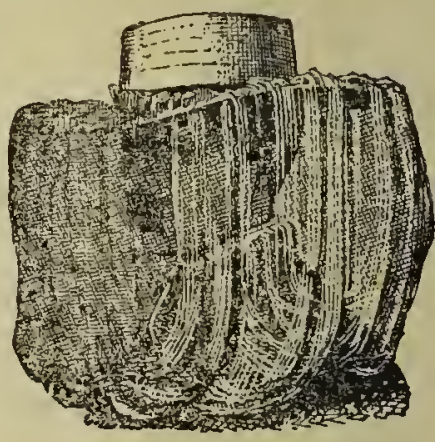

Ven de tule com as luvas de pelle que, precisando de ser muito grossas para cvitar a introducção do aguilluão, tormam-se demasiado incommodas e desagradaveis, causando, além d'isso, um calor insupportarel no verão.

As luvas de algodão tecm tamben o merito de podereu ser lavadas, o que não acontece com as de couro, que, conservando depois de algum tempo de uso o cheiro. de mel, fazem com que as abelhas procurem insistentcmente as mâos, o que causa certo enıbaraço aos traballıos e faz com que inutilnıente sejam esmagadas muitas.

As luvas de pellica fina não servem para resguardo das mãos, pois a abelha trespassa-as facilmente com o aguilhão. 


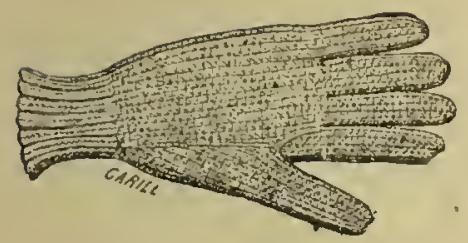

Lavas de al godào

Com este simples material, que deixamos apontado, não ha receio das picadas, e traballia-se melhor, mais á rontarle, pois o cuidarlo em evitar o ataque das abelhas não deixa, nas operaçôes apicolas, quando feitas sem resguardo, que o opcrador preste á sua tarefa toda a attenção que ella requer.

A irritabilidade das abcllas tem, por mais de uma rez, sido aproveitadil, com o melhor cxito, como meio de defesa.

Numa narrativa de viagens na America, lè-se que a muHer de um colono, vendo a casa atacada por indianos, cm occasião em que o marido estara ausente, terc a presença de cspirito de atirar sobre os assaltantes uma colmeia de abclhas, o que os pòz immediatamente em fuga.

Della Rocer no sen Tratado complcto sobre as alselhas escreve o seguintc a este respeito:

"Lm pequeno eorsario de quarenta a eincoenta homens de equipagem, e tendo a borlo algnmas eolmeias de barro cosido, de que se tinha munido propositadamente nas ilhas visinhas, e conservara enicladosamente fechadas, formon o projecto de ahnorlar nma galera turea, que o persegnia, e onde haria quatrocentos a quinhentos homens. No momento do ataque atiron as colmeias do alto dos sens mastros para dentro da galera, onde, quebrados os reeeptaeulos em mil pedaços, deram liberdade ís abelhas, que sahiram furiosas das eolmeias onde as tinham retido prisioneiras durante tanto tempo.

Os tureos, que ao principio tiuham olhado a approximaçĩo do corsario eom ar de desprezo, e que não esperavam de fórma alguma um ataqne de uma especie tro singular, vendo-se sem defesa enntra a picalura dos pequenos mas terriveis iuseetos, ficaram tão aterrados que só pensaram em pôr-se ao abrigo do sen furor; a equipagem do corsario, porél1r. que se tinha prevenido enm luvas e mma especie de mascara, lançun-se sobre elles a golpes de sabre, apoderando-se da galera quasi sem resistencią.

Os hespanhocs, diz o sur. Pingeron, experimentaram o furor das abelhas no cerco de Tanly. Quanto se dispunhan1 a dar assalto á praça, os eereatos guarneceram as hrechas com eolmeias, sendo impossivel aos assaltantes passar além d'ellas. 
Amurat, imperador dos turcos, tendo cercado Albella Grecqne, e destruido os baluartes que a defendiam, encontrou, ao ordenar o assalto definitivo, as brechas defendidas por abclhas, cujas colmeias tinham sido trazidas por os ccrcados para as ruinas. Os Janisaros, apesar de sercm a milicia mais valentc do imperio ottomano, não ousaram transpòr o obstaculo que lhe oppuzeram.»

Schweinfurt conta, na narratica da sua viagem em Africa, que a corda que the arrastara o barco pelo Nilo acima, tombou, por acaso, uma colmeia cheia de abclhas, que, furiosas, atacaram os passageiros do barco, ferindo-os a todos, e em especial a dous negros, que morreram $\mathrm{cm}$ virtude das picadas.

Na batalha de Sadora, em 1866, um obus atirado pelos canhõcs austriacos cahiu en uma casa occupada pelos prussianos, e dcitou por terra uma grande porção de colmeias que alli haria. As abelhas atiraram-se aos carallos, e aos soldados, de tal fórma, que dous homens e muitos carallos morreram em poucas horas, e, a maior parte dos soldados, tiveram de recolher á enfermaria, onde cstireram en curativo durante semanas.

Na batalha de Beaumont, em 1870, os soldarlos prissianos, tendo invadido a aldeia de Warniforêt, quizeram roubar o mel de numcrosas colmeias que alli encontraram em uma granja. Com os sabres tiraram os tampos ás colmeias e começaram a extrahir os favos. Porém as abelhas, que se não conformaram com a espoliação, cahiram denodarlamente sobre elles, de tal nodo, que quatro soldados ficaram logo alli mortos; quatro outros morreram mais tarde, em consequencia das picadas e o resto ficou incapaz de fazer serviço algumdurante mais de nm mez.

No rerão de 1891 presenciamos tambem o seguinte facto, n'uma propriedade de familia proximo da villa de Paredes. Ao lado de uma eira, em magnifica exposição, estaram dous cnxames, carla um em seu cortiço, os relhos e antiquados cortiços. Havia muito que as duas colonias alli trabalhavam pacificamente, sem se importarem com o bulicio da eira, nem teren nunca picado uma unica pessoa. Uma tarde porém, un 
malhador de milho, em desastrado morimento, baten com o mangoal em un 'dos cortiços, tombando-o. As abelhas sahem en tropel, em larga nuvem, picando quasi todas as pessoas que se encontravam no local do sinistro. Apesar de ser immediatamente reparado o mal, n'aquelle dia a ninguem mais foi possirel approximar-se da eira, e nos seguintes, logo que os aldeãos começaram a malhar, ans primeiros morimentos dos mangoaes, as abellas ataearam denodadamente, pelo que foi preeiso mudal-as de logar. Mas, o que é mais eurioso, é que, emquanto procediam assim as abelhas do cortiço que reecbeu a pancada, as do nutro, que nada tinla soffrido, continuaram a suluir e cutrar soeegadamente cntregues ao seu labor, sem prestarem a mais leve attenção an que an redur d'ellas se passava, sem se importarem com o que faziam as visinlas, entregues só á sua ocenpação, e de nada mais querendo saber. Não tinham bolido com ellas para que haviam pois de intrometter-se em querelas de estranhos?! 


\section{O enxame. A apanha dos enxames. Enxames naturaes e enxames artificiaes}

Se "a colmeia 6 muito grande raras rezes as abelhas a tentam deixar. Na America, no estado de pura liberdade, encontram-se enxames immensos nas caridades das arvores, com os faros amontoados até á altura de nulutos metros.

Nas colmeias pequenas, na epocha de abundancia, com o. demasiado desenrolvimento da populą̧ão produz-se a tendencia de enxamear, que não é outra cousa senão a necessidade dla propagação natural da especie.

E geralmente a femea mãe do anno anterior que sahe com a nova colonia, para se estabelecer n'outra parte, ficando na velha as femeas noras ainda nos alreolos. $\hat{\mathrm{E}}$ este o enxame primario.

Os outros enxames, que sahem dias depois, com femeas mães virgens, que estiveram retidas no alveolo, e só vão obtendo liberdade das obreiras que as guardaram á medida das partidas das rainhas mais velhas, teem o nome de enxames secundarios.

O primeiro enxame secundario sahe oito ou nove dias após o primario, e o segundo e terceiro, quando isso se dá, tres ou quatro dias depois. Algumas rezes, mas raro, sahem dous enxames secundarios ao mesmo tempo, o que torna um pouco mais difficil a sua apanlaa. Estes enxames secundarios, a que entre nós se dá o nome de garfos, teem insignificante valor e 
raras vezes ringam, servindo só para enfraquecer a colmeia mão que, com cada uma das migrações, perde a terça parte dos seus habitantes.

É geralmente na força do calor, das onze ás duas horas da tarde, que os enxames sahem, o que não quel dizer quc não possam partir antes ou depois d'aquellas horas. É preciso que o tempo esteja muitissimo quente, para sahirem de manhã cedo, ou ao cahir da tarde. Isto porém é pouco frequente assim como o sahirem com dias chuvosos, de nevoeiro on muito vento.

"Nós temos mais de uma rez, diz Langstroth, segnido, nas nossas colnneias de observação, as acços e os gestos dos enxames. No dia fixalo para a particla, a rainha está inquieta, e, em logar de pôr, corre pari um larlo e para ontro, sobre os faros, communicando a sna agitaç̃̃o a toda a população. As abelhas, que se preparam para partir, abarrotan-se de mel no momento da sahida. Comtudo notamos já $11 \mathrm{~m}$ caso, em que ellas se abarrotaram mais de duas horas antes de deixar a colmeia. Alguns instantes antes do enxame sahil vê-se de ordinario $11 m$ pequeno numero de abelhas voando diante da colmeia, com as cabeças voltadas para o lado da entrala; afastam-se e depois entram como impacientes pela demora. No fim dá-se uma violenta agitação na colmeia; as ahelhas estão como loidas, rolteando solre os faros, em circulos que se alargam mais e mais, conro os que prouluz mma pedia ar'emessada com força sobre a agua dormente, até que toda a populaçĩo entra en $11 \mathrm{~m}$ estado de grande fermentação; então, as abelhas, corremdo para a entrada, com impetuosidade, sahem em jacto contimo. Nem uma só abellia olla para traz, todas se ar'remessam para fóra, como se voassem para salvar a vida, ou como se, impellidas por qualquer potencia invisivel, fossem olrigadas a ir para a frente.

Muntas vezes a rainha não sahe senão quando um. certo numero de operarias a deixaım, acontecendo ató, quando está mnito pesada pela quantidade de oros contidos no abdomen, a não poder voar, cahindo ao. chão.

As abelhas apercebem-se ben depressa de que a mãe as não segnin; entĩo é-se espectador de nuna scena muito interessante. As obreiras procuram com ancia a măe perdida, dispersando-se o enxame em todas as direccões. As follias dos arbustos proximos colrem-se cle abelhas anciosis, tĩo proximas numas das ontias como as gottas d'agı após $1 \mathrm{~m}$ aguaceiro. S'e não conseguem encontral-a voltam para a colmeia, de orlinario cinco a quinze minutos depois." 
As abelhas, sahidas da colmeia, elevam-se em turbilhão, assegurando-se da presença da femea fecunda. O vôo não é geralmente longo, principalmeute o do enxame primario, que leva a femea màe fecundada cheir d'oros, e portanto pesada. Os elxames secundarios, com a femea rirgem, sem oros, vôam para nuito mais longe.

Quando cançadas, pousam n'um ramo d'arrore, ligando-se umas ás outras pelas forquilhas das patas anteriores encaixadas na das patas posteriores das que estão na fila superior, e agarrando-se ao ramo e folhas do vegetal pelas patas diantei-

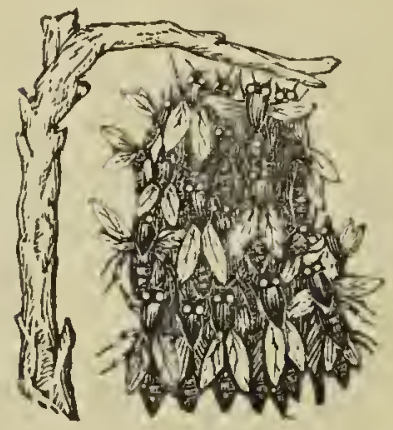

0 enxame ras: este modo de suspensão evita qualquer fractura vas delicadas membrauras das azas. A fórma que o $\mathrm{cn}$ xame então apresenta ó a dc um cone roltado, fechado de todos os lados por abelhas, excepto no.vertice, onde deixam una pequena aberturia para a sahida dos insectos que se encontram do lado de dentro.

Este enxame, se não é recolhido pelo honem, vae estabelecer-se na tóca de uma aryore, n'uma parcde arruinada ou qualquer cavidade aberta no sólo. Um homem completamente resguardado com a mascara e luras proprias, on mesmo sem mascara alguma, pois, geralmente, em virtude de, antes de sahirem da colmeia as abellias se terem abarrotado de mel, é raro procurarem ferir, agarra o enxame facilmente, logo que as abelhas reunidas estiverem tranquillas, collocandothe por baixo um cortiço on receptaculo identico feito de palla, bem fresco, e internamente untado de mel, sacudindo o ramo e voltando depois o cortiço e pousando-o no clião. Se entre as abelhas que cahiram dentro, foi a femea mãe, toda a colonia entra logo, estabelece-se definitivamente e começa a traballiar.

Mas se a mestra fica fóra, é então necessario recomeçar a operação, pois todas, as abelhas correm a juntar-se á mãe 
feeunda. Se o enxame sahe da primitiva eolmeia scm femea mãe, depois de roar durante algum tempo, torna noramente a eutrar, para sahir d'ahi a dias, fazendo o que em apicu!tura se channa uma falsa sahida.

Aeontcce muitas rezes que os enxames pousam n'um alto ramo d'arrore, ou se abrigam na caridale de uma arvore ou reho muro. No easo de estar en ramo alto fixa-se a comeia de palha ou o cortiço em uma rara comprida, da altura precisa para ehegar an enxame, e, emquanto uma pessoa conserva assinı a eolmeia sob o enxame, outra, por meio de uma rara com un gancho na ponta, sacóde o ramo.

Quando o enxame está em qualquer cavidade trata-sc de abrir uma sahicla na parte mais elevada do local onde elle se encontra, e, por o orificio inferior; que servia de entrada ás abelhas, projeeta-se fumo até ellas passarem todas para o eortiço.

Se o enxame está pousado no sólo, ou cm qualquer saliencia proximo d'elle, põe-se-the a eolmcia por eima, e as abelhas immediatamente entram todas n'ella.

As abelhas do noro enxame, logo em seguida á sua installação, começam a traballıar, eonstruindo rapidamente os alveolos. É provavel que leven já eomsigo a eêra preparada no abdomen, pois, muitos dias antes do enxame sahir, as abellias suspendem os trabalhos e permanecem amontoadas em eaeho, immoreis, na elevaçĩo de temperatura requerida para a elaboração da eèra, armazenando assim a quantidade indispensavel para os primeiros trabathos.

A eolmeia vella fica eom larras nães nos alreolos. Sc ella está muito fórte e ha tencheneia para a salıida de novo enxame, as abelhas dão liberdade á primeira femea mãe e eonservam as outras enidadosamente sequestradas nos alveolos, onde as sustentan abrindo $u m$ pequeno orifieio no opereulo para deixal passar a comida; ó então que estas mestras prisioneiras fazem ouvir uns doees queixumes, eonhecidos pelo nome de canto das rainhas; no caso de não sahil mais enxame algum, livrentente deixam a que primeiro unsceu, depois de fecuudada, desfazer-se das restantes rivaes. 
A sahida de muitos enxames d'uma colmeia, ainda que fórte, como já dissemos, debilitam-a bastante, e ás vezes levam-a ao completo amniquilamento, durante o inverno, pela falta de provisões. Mesnio, muitos dos enxames sahidos com femea não fecundada, perdem-se, disseminam-se, ou pela morte d'esta, ou pela sua não fecundação a tempo.

Por isso la toda a utilidade ein eritar que as colmeias enxameiem; quanto mais numerosa fôr a população tanto naaior quantidade de mel armazena, fim principal a que dere tender todo o bom apicultor.

Com o velho cortiço é impossirel evitar fructuosamente a sahida de enxames, o que só se póde realisar praticamente con as colmeias moreis.

Para isso, no principio de maio, visitam-se as colmeias-e vê-se se os quadros cstão cheios de crenção on não. No caso affirmatiro, procuram-se as cellulas reaes, e, logo que se encontran, inutilisam-se. Estas cellulas são faceis de conliecer, pois semelham, no aspecto externo, as glandes dos carvallos, e estão gerahnente situadas ao lado e na parte inferior dos favos dos quadros. Isto porém nem sempre dá o resultado requerido por isso que, muitas vezes as abelhas, não levando a bem a inutilisação das cellulas de mães, constroem logo outras, geral-

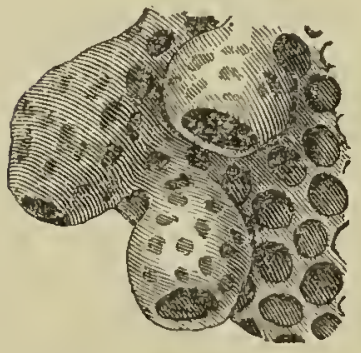

Cellulas reaes ou de abellhas mães mente em muito maior numero que as primeiras.

O melhor é tirar meia duzia de quadros com creação, que se levam para uma colmeia fraca, fortalecendo-a, e substituil-os por outros apenas com cèra moldada na parte superior; para dar mais serviço ás obreiras, e ventilar bem a colmeia. Tambem é conveniente então, pôr-lhe a alça, ou um andar, com seções completaniente separadas do corpo principal por meio de uma lamina de zinco furado, e com aberturas que só deixam passar as obreiras, e não os machos e a femea mãe, que são muito mais corpulentos. 


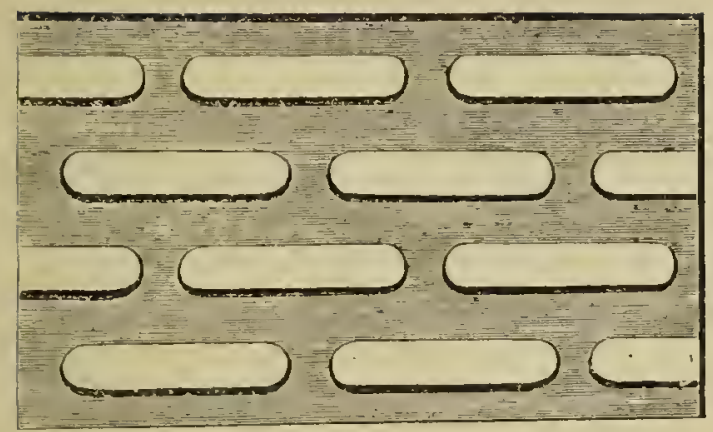

Zinco furado para deter os machos e femeas mães

Isto faz com que a femea mãe não possa proceder á postura llos novos quadros on seç̧oes e que, portanto, as obrciras se vejam obrigadas, depois dos

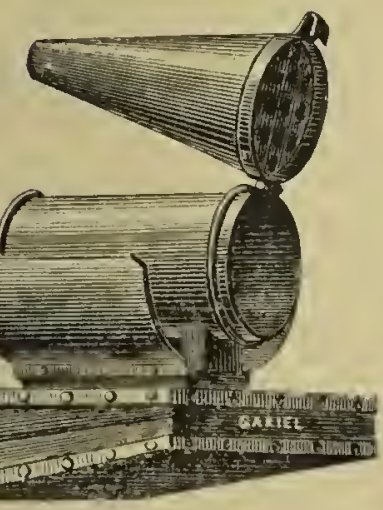

Folle lingliam faros construidos, a enchel-os de mel, tarefa em que empregam uma grande parte, senão todo o verão, não necessitando assim de ellxamear.

Conrém recordar que todas estas operaçōes se fazem auxiliadas com pequenos jactos de, fumo que, por meio do folle, se lançam de tempos a tempos sobre as abelhas. O mais apreciavel de todos os apparelhos para tal fim 6 o folle Bingham.

O melhor meio de obstar á enxamagem natural, que muito cufraquece as colonias, é a creação artificial de enxames. A enxamagem artificial parte do principio de que as abellas, quando lhes falta a mestra, transformam immediatamcute $\mathrm{cm}$ fentea mãe toda e qualquer larva de obreira que não tenha chegado ao seu completo desenvolvimento.

Portanto, liavendo faros com creação recente e bastantes machos, póde fazer-se, com toda a segurança, a enxamagem 
artifieial, na eerteza de que as obreiras obterão de prompto uma femea mãe, que, depois de eonrenientemente feeundada, fará a riqueza e a prosperidade da eolonia.

A enxamagem artifieial tanto se póde fazer eom as eolmeias fixas eomo eom as moreis; estas porém facilitam e tornan mais fructuoso o trabalino, que se pócle seguir e rigiar enidadosamente, emiquanto que n'aquellas é mais rudimentar; mais grosseiro e defeituoso.

E regra geral que se deve operar en plena primavera, o na força da eollıeita e da posturi, escollıendo sempre, quando se tratar de eolmeias fixas, um eortiço fórte, pesarlo, bem povoado, e que tenha muitos machos.

Estando o tempo freseo póde-se proeeder ao trabalho das dez da manlıã ás eineo loras da tarde; se porém fizer muito ealor, só se dere operar das oito ás dez da manlıã, on duas horas antes do pôr do sol, afin de evitar que haja extravasamento de mel 110 cortiço, o que teria o mau resultado de natar muitas obreiras e prejuliear o bom exito da operação.

Pega-se na colmeia d'onde se quer extrahir o enxane, deita-se-llie internamente um pouco de fumo, afim de fazer eom que as abellas se abarrotem de mel, e, uns dez minutos depois, rolta-se unindo-a bòea eom bòea a uma ontra eompletaniente rasia ou, eono eostumamos proeerler, sempre eom bom resultado, unindo-as só n'una extremidade e deixando, durante toda a operação, uma pequena abertura do mesmo tamanho, formando angulo, que se eonserva eerta por meio de duas eavilhas ou dous $S$, abertura esta que permitte o seguir a passagem das abellas e rerifiear, na maior parte das rezes, a existeneia da rainha. Dispostas assim as eolmeias, bate-se eadeneiada e vagarosamente na eolmeia velha, obrigando duas terças partes das abelhas que a poroam a passar para a nova; se porém ellas estiverem teimosas em não fazer a mudança, aetiram-se por meio de pequenos jaetos de fumo, estimulo vjolento a que não resisten.

Convém reeordar que o fumo dere ser projeetado eom methodo e en pequena quantidade, não só para não prejudiear 
as abelhas, mas tambem para não asphyxiar a creação que está nos faros.

Installadas as abelhas na casa nova rerifica-se sc com ellas foi a femea mãe, ponsando a colmeia sobre um panno preto e, depois rle se lhe ter bem tapado torlas as sahidas, batendo n'ella fórtemente umas poncas de vezes. Retirando-a em seguida le sobrc o panno, no caso da mestra estar na colmeia, rè-sc sobre clle pequenos pontos brancos a que os nossos lavradores dão o nome de vareja, pela semelhança que tcem com os oros da mosca da carne a Calliphora vomitoria, e que não são mais do que oros que a femea mãe, sobresaltada, deixa caliir no panno.

No caso de não havel a certeza da femea mãe ter acompanhado o novo enxame, ó melhor leixal-o recoller á colmeia antiga e recomeçar a operação dias depois. Tendo ficado porém a mestra na colmeia nora, colloca-se esta cm sitio distante, e, a que ficou com os faros e a creação, no seu logal usual.

Assim as abelhas, que andam por fóra atarefachas na cotheita, poroam o cortiço relho, e, sabendo que um berço grande e um sustento abmudante desenvolrem o organismo e fazem salii de uma abella obreira uma abellıa mestra, logo que se rêẹm privadas da sua, rĩo a tres on quatro cellulas e transformam-as em uma só com un só oro. Nutrem depois a larva que fica n'essa cellula maior, com um sustento abundante c especial, uma especie de geleia formada de uma mistura de mel, pollen e oros, que far com que todos os seus orgãos se desenvolram c robusteçam por completo. As propriedarles prolificas d'esta geleia são tão fórtes que qualqner obrcira provando-a, ainda que em pequena quantidade, fica por esse unico motiro fecundarla.

$\hat{\mathrm{E}}$ devido a isto que as obreiras nascidas proximo das ccllulas das mestras são, en geral, dotadas de mais on menos fecundidade, pondo porém apenas oros de zangãos.

Se se vir que as obreiras, que andavam fóra, não são sufficientes para cobrir e aquecel a creação que ficou no cortiço velho, augmentam-se collocando os dous, o cortiço da 
creação e o cortiço novo ao lado um do outro e trocando-os duas ou tres vezes durante o dia seguiute ao da mudança.

Assin as abelhas dividem-se proporeionalmente pelos dous cortiços, ficando em um sufficientes obreiras para tratarem da creação, e no outro as indispensaveis para a rapida construcção de faros onde a rainha, que as acompanhou, possa procedor á postura.

A enxamagen artificial com as colmeias moveis essa ó simplicissima e o melhor de todos os meios de, eln pouco tempo, se poder conseguir, con toda a segurança, boa e fórte reproducção.

Na foręa do traballıo da colonia, ao meio dia, tira-se a colmeia sobre que se quer operar para longe, e, no logar d'ella, colloca-se una vasia, e com as paredes internas levemente untadas de niel, para que n'ella se demoren as abelhas que forem entrando.

Do ceutro da colmeia povoada retiram-se tres quadros, que tenham creação nova, sacudindo d'elles, por meio das barbas de uma penna de pato ou perú, tollas as abelhas que trouxerem adherentes. Estes tres quadros levam-se para a colmeia desporoada e collocam-se-lhe a centro, enchendo depois os espaços rasios de quadros conı cềra moldada. Assim, as abelhas que andavan fóra, poroam a nova colmeia $e_{\text {; }}$ em vinte e tantos dias, teem uma fenea mãe fecunda, pois leva doze a treze dias a obtenção da mestra e, seis ou sete dias depois do nascimento, a fecundação, começando a postura quarenta e oito horas depois.

Para facilitar o traballıo das abellias convém alimental-as artificialmente durante os oito ou dez dias que se seguem á enxamagem artificial.

O grande apicultor francez snr. G. de Layens descreve da seguinte fórma o processo por elle seguido para fazer os seus enxames artificiaes:

"Escolho, por exemplo, duas colonias nuito fórtes, que designo por A e B. T'iro da colmeia B todos os favos, limpando d'elles todas 
as abellias para dentro dla colmeia. Á medida que tiro os faros, substituo-os por quadros largamente iseados. Em logar d'estes quadros iseados póde-se pôr quadros construidos, com as cellulas dos machos supprimidas. Utiliso assim faros eontenlo ao mesino tempo cellulas de obreiras e cellulas de maehos. Tenho todo o cuidado em, colloeando sueeessivamente os faros, alternar os que possuem mais eêra, eom os que teem menos. Os faros sem abelhas, tirados da colmeia $B$ são collocados provisoriamente nas caixas de quadros.

A enlonia $B$ é, em virtnde d'isto, tornada a levar ao estado de enxame: segundo a força que ella possujir cleve eollocar-se n'esta colmeia $B$ até dezoito qualros iscados, e, não longe de uma das extremidales d'esta mesma colmeia B, 11 m favo de ereação e de mel. Esta creação serve para reter o enxame na eolmeia, e n mel é ntilisado nelas abelhas no easo de man tempo.

Terininada esta primeira operaçăo, os faros que estiverem nas caixas são collocados, sem the mudar a ordem que oecupavan na colmeia B, em nuna nova colmeia C. Depois d'isto resta só collocar a nova colmeia $\mathrm{C}$ que não eontém abelhas, no logar da colonia $A$, a qual é transportada para outro sitio no eolmeal. Dero fazer notar que, 1 'este processo de enxamagem, o enxame possue todas as abelhas la colmeia mãe $B$, o que the dá 1 mo podel de trabalho consideravel; vi assim cuxames de quatro a cinco kilos eolher cineoenta a sessenta libias de mel em algumas semanas, e acatar quasi completanente quinze a dezoito quadros iseados.

Quanto á nova eolmeia $C$, que se reporoa eom a ajuda das abethas da colonia desloeada $A$, năo dá, senăo raras vezes 11 m enxame secunclario, o que é uma rantagem.

Para que a colmeia sem abclhas C, se reporoe sufficientemente, é preciso operar a enxamagem na manlĩ de $\mathrm{um}$ dia relativanente quente $\left(18^{\circ}\right.$ a $\left.20^{\circ}\right)$, que é quando as ahelhas são muito activas. Emfim, para clar tempo ao enxame de construir novos faros, antes da grande colheita, o necossario operar una duzia de dias antes da epocha provarel da sahicla dos enxames natıraes na região."

Tambem se obtem facilmente um enxame artificial da seguinte fórma:

Tira-se de uma colmeia fórte o quadro em que estiver a femea mãe, com ella e com todas as obreiras que a acompanharem, e colloca-se en uma colmeia rasia, enchendo o resto com quadros de cêra moldada, e installa-se esta colmeia no logar que occupara a antiga, que se leva para longe. Assim, 
as abelhas que andaram por fóra, véem reunir-se á mãe na nora colmeia, e as que ficaram na relha, como teem creação em abundancia, de prompto fazem uma.

O celebre apicultor inglez snr. Th. W. Cowan, no seu Bec-lieeper's guide book, ensina da seguinte fórma a fazer tres colonias de duas:

"Este methodo é muito simples, dá muito bom resultado e póde ser praticado por aquelles que desejarem obter muito mel angmentando moderadamente o numero das suas colonias. É impossivel, sem que haja mma mui grande habilidade, obter ao mesmo tempo, e na mesma estação, una grande quantidade de mel e muitos enxames.

Em um dia magnifico, quando o maior parte das alellias andarem por fóra atarefadas no sen trabalho, tira-se de uma colonia fórte cinco quadros contendo crcação e oros, sacudindo. on deitando con uma penna na colmeia, todas as abelhas que elles trouxcrem; dispõem-se estes quaxlros em uma nova colmeia e enchem-se depois as duas de quadros com cêra moldarła ou faros vasios. Destocia-se em seguida nma ontra colonia, que se leva para longe, e põe-se a nora colneia no logar que ella occupara.

D'este inodo una colonia dá os favos emquanto que ontra fornece as abellas, por isso que, as abellas pertencentes á colmeia deslocadia, que andavam por fóra, voltam an sen antigo logar, fornecendo assim á nova colmeia a precisa população, que começa immediatamente a fabricar cellulas reaes.

No caso de se possuir rainhas já fecundas, adianta-se muito o noro enxame fornecendo-lhe uma dentro de uma gaiola d'onde se solta passado trinta e scis horas.»

Segundo o snr. Ch. Derosne, o habil auctor da Colmcic-Album, o meio mais simples de obter bons enxames artificiaes consiste em, na epocha da maior producção mellifica, de abril a maio, tomar en uma colmeia bem populosa cinco ou seis favos contendo creação e pollen:

"Esta operação, feita n'um dia magnifico, das dez ás duas, emquanto a maior parte das obreiras andarem pelos campos, deve ser praticada com todo o cuidado para não incommodar as abelhas quc cobrem os faros. Collocam-se, com precaução, estes quadios no centro da colineia que se quer povoar, juntando-lhe, de cada lado, tres ou 
quatro quadros com favos vasios on cêra moldarla. As entradas tendo sido anticinadamentc fecharlas por meio da rêde metallica, transportase esta colmcia a $11 \mathrm{~m}$ logar obseuro, para lima arlega mesmo, onde se deixa tres on quatro dias, administrando-lhe, por meio do alimentador, tanto mel quanto porlerem consumir. No fim d'este tempo as abellias tecm perdidn a ideia da sua antiga habitaçĩo, e apenas algumas velhas obreiras se escapam quando, tendo sido installada a colmeia no sen logar definitivo, sc the abre as portas.

Seria vantajoso tomar, para formar o enxame artifieial, o quarlro onde existe a rainha e deixar orphã a colmcia-origem? Se se não podér descohrir a rainha divide-se entre as duas colmeias o que se encontrar de eriação tendo mais de tres dias de idade. Comtanto que nem na nova nem na antiga colonia falte eriação recente, o bom resultado é ecrto.

É facil reconhecer a ollıo nú a idade dos ovos depostos nos alreolos. No primeiro dia o oro apparece no fundo da cellula como nma bilharda voltadla verticalmente contra a divisão media; no segundo dia a billıarda, já um ponco enrra, toma uma posição obliqua; no terceiro dia vê-se deitada horisontalmente; no quarto o ovo está naseido salindo d'elle uma larra.

Nos dias seguintes á divisio da colonia em duas seceñes, as abellas da colncia orphĩ transformam uma ou muitas cellulas de obreiras em cellulas reites e, por meio de nm sustento mais succnlento, determinam o desenrolvimento dos oros de obreiras em larras de rainhas. A primeira rainha nascida mata as irmãs no berço e, poreo depois de feeundada, eomeça a encher com a sua postura os alreolns rasios da eolmeia, onde não tolera rivaes, e onde, eom mais verdarle que Luiz XIV, pótle dizer: O Estarlo son en!

Este processo tem o inconreniente de deixar durante quinze llias, ou tres semanas, uma colonia sem femea mãe, por isso que é preciso ponco mais on menos este tempo para formar uma mãe. Para evitar isto muitos apicultores preferem educar as rainhas em pequenas enlmeias especiaes e, esperar que sejam nascidas e fecundadas, para formar o enxame artificial de que acialamos de fallar:»

De tortos os methodos de enxamagem artificial, o mais preconisado e seguido no estrangeiro é o de Tignole, que o auctor descreve da seguinte fórma:

"Um lom methodo de cultura leve poter applicar-se a todas as fómas de colmeias e a todas as locialidades, exceptuando, já se vê, as modificaçues aecessorias que reclamam as exigeneias dos instrumentos 
empregados e dos recursos do sólo: o principio é immutavel. Se a colmeia de quadros moveis não se presta ao acossamento das abelhas por meio do bater compassado n'ellas, ainda que isto seja possivel com as colmcias bem construidas, tem comtudo grandes e apreciaveis facilidarles de execução; mas nào se trata agora d'isso, mas simplesmente de tirar, com a mãc, dous quadros, possuindo juntos dez mil alveolos de creação e outras tantas abelhas. Estes dous quadros são collocarlos no centro da colneia destinarla a recebel-os. O enxame assim feito é posto immediatamente no logar da mãe, e este vae occlipar o logar de uma colmeia fórte, que é levada para longe.

Treze dias depois, por isso que a larva mais nova que as abelhas pódem escolher, é sahirila de um oro posto de tres clias; por conseguinte estes tres dias de incubação do ovo juntos aos treze dias, constitucin o tempo normal consignado ás metanorphoses da abelha femea, que é approximadamente de dezeseis rlias, tiram-se ainda dons quadros bem fornecidos de creação c de obreiras; estes dous quadrós constitnem o segundo enxame, que é tratado sempre empregando a permutaçũo. A permutação é o acto pelo qual una colmeia cede o seu logar a outra. Aqui a colmcia operada cécle o logar an sen enxame e vae occupar o dc uma colmeia fórtc; as obreiris que andam nos campos, véem em multiclão fortificar a estranha, que repara assim a perda soffrida e adquire, pela leunião d'estas obreiras traballhadoras, uma potente forẹa d'acção para a colheita, que the permittc desenvolver-se rapidamente.

D'esta segunda extracção de quadros é preciso rerificar se a joven mãe nascidla está conı o enxame; ú uma necessidade, porque sem isso o enxamc não teria bom exito, visto que a creação não cstá já nas condliçoes requeridas para ser transfornada. Se se quizer evitar o cuidado de assegurar a presença da mãe no enxame, é preciso anticipar dons dias a operação, afim de haver alveolns maternos fechados, fazendo-o no decimo primeiro dia, on mesmo no decimo; n'este caso é prcciso supprinir todos os alveolos maternos, que se encontrarem no enxame e na colmeia d'onde elle foi tirado, menos um. Pela nossa parte preferimos esperar até ao decimo terceiro clia, por isso que, então, estamos seguros de possuir uma joven mãe viva, vautagem que não existe tirando os alreolos aindla operculados, por isso que se póde dar o caso dos alveolos operculados năo valerem nadla.

Esta colmeia, l'onde forem tiraclos os cnxames, poderá ser guardarla completamente, do vigesimo primeiro ao vigesimo quinto dia a partir da sahida do primeiro enxame, no momento em que ella năo tem ainda nadla a recear. dos inconvenientes da sıa posiçăo perigosa. A tinha não pódc apoderar-se d'ella, por isso que a população é ainda muito poderosa; as vespas estão por nascer; as abelhas das outras 
colmeias, occupadas na colheita, não pensam em atacar as suas visinhas desorganisadas, senão quando não encontrarem mel nas flòres seccas; e por outro lado, livre de toda a creação, e tanto quanto possivel de materias estranhas ao mel, dá um producto mais puro e torna a manipnlação mais facil.

Póde pois ser conservada para a estação seguinte, no caso de assin se desejar, depois de se ter verificado n'ella a presença de uma joven mãe. O renovamento das niães póde igualmente fazer-se com simplicidade e facilidade. O meio eil-o: guardar completamente as colmeias possuindo mães velhas on defeitnosas, e conservar as que as teem novas.

Ha no mundo processo mais simples e mais facil?» 


\section{Obtenção, renovação e transporte de abelhas mĩes}

Um dos pontos capitaes para o bom desenvolvimento de uma colonia é que a abelha mãe seja fecundada, fórte, rigorosa e nova. Uma abelha mãe põe de quarenta a cem mil oros por anno, postura que pórle, em casos extraordinarios, pouco frequentes, subir a quinhentos mil; põe mais nos paizes quentes e temperados, mais ainda nas colmeias grandes e quentes, e muito mais na cêra nova do que na relha. Como já tive occasião de dizer, a abelha mestra vive quatro a cinco annos, mas depois do terceiro anno, envelhecendo, a postura começa a diminuir, o que é um grande inconveniente, ou a pôr só oros de machos, o que é a completa ruina da colonia. Muitas rezes, chegada esta occasião, as obreiras desfazen-se implacavelmente da mestra; mas não devemos só fiar-nos n'isso, e rigiar antes cuidadosamente pelo estado da postura, afim de substituirmos de prompto a femea mãe, logo que isso seja preciso.

Aqui se recouhece mais uma rez a superioridade das colmcias moveis, pois facilmente se rê, lerantando e examinando os quadros, se a postura se mantem normal, ou se as cellulas dos machos predominam, emquanto que com as colmeias fixas isso só se poderia verificar passando a colonia de uma para outra colmeía.

Acontece tambem morrer a abelha mestra, sem deixar creação em estado das obreiras poderem obter outra mãe, nem 
haver, na occasião, nas ontras colmcias, creação propria para isso. Teriamos a contar um enxame perdido sc, em tempo competente, não tivessemos feito a conveniente provisão de abelhas mestras em quantidade sufficiente, conforme o desenvolrimento do nosso colmeal.

Póde tambem ser uma boa fonte de receita a renda de abelhas mães aos apicultores que d'ellas necessitarem, e 1 m meio de obter obreiras fórtes e robustas, obstando á consanguinidade pela troca de mestras com outros apicultores da localidade.

Como se rê, é na creação artificial da mãe que reside todo o admirarel principio mobilista.

Geralmente, cntre nós, com a réles e detestarcl cortiço, a reprodução ó feita por meio dos enxames primarios, que, levando comsigo a mestra velha, cuja idate se ignora, e que, na maioria dos casos, já está no declinar da postura, não progridem, dando motivo a constantes insuccessos desagradareis.

Com o mobilismo está isso remediado, não só com a creaç̃̃o de enxames artificiaes, mas tambem com a suppressão e a substituição da abellıa mãe.

Nada mais simples.

Mas para se poder apanhar e substituir a mestra relha é preciso haver outras novas, rigorosas e fecumdadas que a substituam.

Eis como isto se consegue.

Escolliem-sc duas colonias fórtes c que trabalhem bem, dando mostras de que a mestra é prolifica e activa, visto que a descendencia possuirí sempre as qualidades boas da nãe. Na primavera, tiram-se os quadros que ellas tiverem, substituindo-os, a uma, por outros com cêra moldada só com alreolos de fomeas, e ál outra, por quadros com cêra só com alveolos de maclios, dando em seguida a ambas uma alimentação boa e constante.

Isto tem por fim fazer com que ao tcmpo da sahida das abelhas mestras haja machos promptos a fecundal-as, e machos 
de uma colmeia differente, para eritar os inconvenientes da consallguinidade.

Obtida a postura dos machos, e, logo que elles estiverem prestes a sahir dos alveolos, procura-se e apanha-se a abelha mestra da colmeia que só tere cêra com alreolos de obreiras, abelha que ou se supprime se é vellıa, ou se guarda para ser fornecida a outra colonia. Terifica-se se nos alveolos ficaram oros recem-postos, e, 110 caso affirmatiro, deixa-se ás abelhas proceder ao fabrico de cellulas reaes de salvação, que são geralmente numernsas, em numero de dez a vinte.

Se então as abelhas não colleven o sufficiente pollen e mel para alimentar fórtemente a creação, ó preciso dar-lhe um bom xarope que as fortifique.

Se o numero de cellulas de mestras, crcadas pelas abelhas, fôr inferior á quantidade de que o apicultor carece, tiram-se os quadros que as contiverem, os quaes se introduzen en outra qualquer colnıeia, e forneccm-se á colmeia noros quadros con creação recente, onde ellas immediatamente formarão novas cellulas de mães.

Para que as abelhas da colneia, onde se introduzirem os quadros com cellulas de mestras, as não destruam, resguardam-se estas por meio de uma rêde de tela metallica, que cobre o alveolo e, sem impedir a alimen-

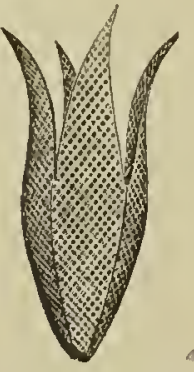

Resguardo metallico dos alveolos de mestra tação da larra n'elle contido, o preserva de qualquel má rontade das abellias a quem é fornecido.

Feito isto teem-se pequenas colmeias proprias, colmeias nucleos, tantas quanto o numero de rainhas a obter, onde se colloca um ou dous favos com creação, com as obreiras que tiverem adlierentes, mas a que se tere o cuidado de exaninar que não tragam a mãe. Deixa-se estar um dia fechada esta pequena colonia, para que as obreiras tenham a certeza de que estão sem mestra, e, no dia seguinte, tira-se da colmeia, que tem os quadros com cellulas 
reaes, todos estes quadros, e, eom uma penua de pato ou perú, sacodem-se-lhe as abclhas que trouxerem adhercntes; em seguida, con uma navallıa muito afiada, cortan-sc as cellulas reacs, menos uma que se deixa ficar, para toruar a introduzir com o quadro na colmeia d'oude sahiram.

Estas cclulas reaes cortan-se com todo o cuidado, deixando-llie ficar á volta algumas ccllulas de obrciras; é preciso não as apcrtar com os dedos para não matar as nymphas n'cllas contidas, nem, pelo mesmo motivo, deixal-as cxpostas ao sol oul ao frio.

Cortadas as cellulas tira-se o quadro da colmeia nucleo, sacodem-se dentro d'ellas as abelhas e, immediatamente, cortase-lhe do centro um pedaço de favo do tamanho do que se tem a introduzir com a cellula real, o qual se fixa n'essa abertura por meio de pequenos alfinctes de arames passados nas cxtremidades, com a cellule da mestra coltada sempre para baixo.

Introduz-sc o quadro na colmeia nucleo, onde dous ou tres dias depois estíl a mestra llascida. D’ahi a uma semana estas nestras salem para ser fecundadas, e então, para isso, e preciso ter proximo d'ella a colmcia onde se auxiliou um excepcional nascimento de machos, aptos para promptamente descmpenharen a sua missĩo.

Para que as obreiras das colmeias nucleos nĩo sáiham todas com a mestra, no momento de ella procurar a fecundação, é preciso, no easo de não torem ercas̃o, fornecer-llıe um quadro coll clla, pois tendo creação nunca a abandonam.

Verificada a entrada da rainha, c que ella rem fecundada, está prompta para ser aproveitada ou mesmo para ser enviada para longe, pelo correio, para o que ha caixas apropriadas, das quaes a melhor é a caixa Benton eom repartimentos para provisôes, um repartimento abrigado e $n m$ arejado, no caso de mudança de temperatura; nos repartimentos de provisícs póde collocar-se mel, faros com mel e, na falta d'estes, assucar candi, com que as abelhas se alimentam pcrfeitamente. 


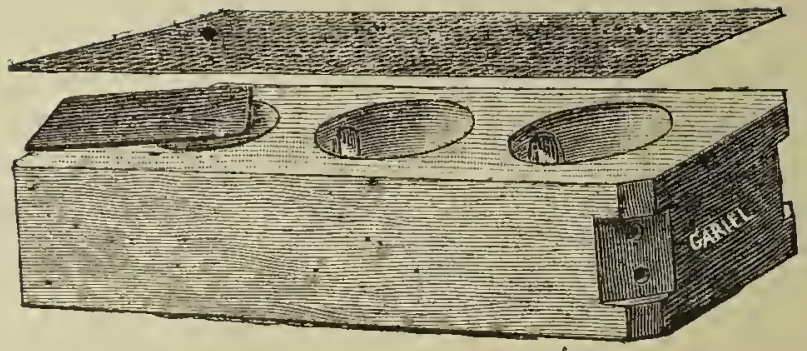

Caixa Benton para transporte de mães

Obtidas as rainhas possue-se o elemento principal para operar as substituiçoes, que devem ser feitas depois das abelhas terem realisado a colheita de mel. Tem isto a conveniencia de deixar que a mestra a substituir tivesse feito a postura, e a creação esteja nascida, não havendo perda de tempo, que se daria, fazendo-se a substituição na primavera.

Nas colmeias moreis é facil encontrar a mestra; depois de se the ter deitado algum fumo tiram-se os quadros, que se examinam um a um, nas duas faces, e, logo que se rê a mestra, apanha-se, agarrando-a pelas azas e introduzindo-a em seguida na gaiola armadilha, ou supprimindo-a immediatamente. Geralmente a mestra encontra-se em um dos dous quadros do centro da colmeia.

Nas colmeias fixas, sobretudo no nosso relho cortiço, é bastante difficil encontrar a mestra.

Hamet no Cours pratique d'apiculture aconselha a proceder então da seguinte fórma:

*Sacode-se a colmeia docemente e successivamente em cinco ou seis pequenos receptaculos; as abelhas cahem e estendem-se sobre as paredes interiores; voltam-se os pequenos receptaculos e, um quarto de hora on meia hora depois, os grupos começam a agitar-se, uns, um pouco mais cedo, e outros, um pouco mais tarde. Un só fica socegado; é o que possue a măc, e é lá que é preciso procural-a. Deita-se fumo a uma das partes que estão agitadas, e sacode-se a trinta centimetros de distancia o grupo que tem a mãe; as abelhas, ouvindo 
o zumbirlo visinho, dirigem-se para esse lado, e, algmns jactos de fımo, obrigam todas a seguir o mesmo caminho.

Qando se vêem em marcha, para transpồ os trinta centimetros que as separam das imãs, ollia-se attentamente, e, logn que se rề a màe, eobre-se com 1 m copo le vichro, que se tem para esse fim na mào.

E curioso vèr entio as abelhas, pois semelham um rebanho de carneiros eom pressa de entrar no curral. Póde-se fazer esta eaça á mãe em numa sala a toda a hora do dia; em pleno ar só deve ser feita de tarcle, uma hora antes de pòr o sol, on de manhã antes clas seis horas.

Olhando attentamente para o panno de linho onde se saeode o enxame 110 momento da reeepcão, póde-se tambem descobrir a mãe e apoderar-se d'ella, ponsando um vidıo por cima; ella fiea a maior parte das vezes acompanhada de abellas que mais tarde pódem ser afastadas facilmente. »

Vinte e quatro horas depois de supprimida a fenca mãe vella, introduz-se a nova, que se tem de reserva. Para isso mette-se csta em uma gaiola cylindrica de rèle de arame, tendo nas extrcmidades dous pequenos reservatorios com ali-

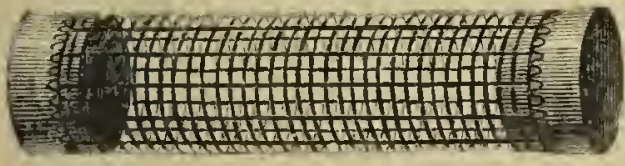

Gaiola rylindrica para introduzir as màes mento, para a não tornar dependente das obreiras, e critar que ás rezes morra á fome.

Abre-se a colmeia, e, com a bòca, borrifa-se levemente de xarope, introduzindo então a gaiola no quadro celltral e fixando-a no meio d'elle.

No fim de vinte e quatro horas verifica-se sc as abelhas cercam furiosas a gaiola, on se prestam carinhosos cuidados á nora mestra. No primeiro caso é porque teem já alveolos de mestras, que ¿ preciso procurar e destruir, conservando depois a mestra presa na gaiola mais nun ou dous dias, e no segundo caso, substitue-sc immediatamente a rolha que tapa um dos lados da gaiola por uma grossa lamina de cèra, untada de mel, e torna-se a collocar a gaiola no primitivo logar, bonifando noramente as abelhas com xarope. Em um dia as obreiras 
teem roido a divisão de cêra, soltando assim a mãe, que então acceitam gostosa's.

Se a mestra tiver de ser dada a uma colmeia que esteve muito tempo orphã é preciso, para que ella a acceite, introduzir na colmeia dous ou tres quadros com creação, e, n'um d'elles, a rainha, que só deve ser solta tres ou quatro dias depois. 


\section{Passagem e reunião de enxames}

A reunião de dous enxames impõe-sc quando ambos cstão fracos, oll quando la algum orphão, isto é, sem abelha mãe, sendo então preciso, para que não se perca irremediarelmentc, juntal-o a uma outra colmeia fraca, afim de, coll duas, uma fraca e outla pcrdida, obtel-se uma colonia populosa e fórte. A reunião de cnxames tanto se póde fazer com as colmeias fixas cono com as moveis, mas ć muito mais facil com estas do. que com aquellas.

Como o nosso traballıo é essencialmente mobilista, - 0 unico systema de resultado certo e seguro, - só accidentalmente é que nos referiremos ao fixismo, vello e de defeitos

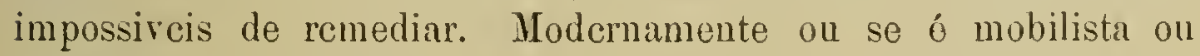
então não se .e apicultor.

Encontrada uma colneia orphã e verificado que clla não tem creaçấo que lhe permitta obter uma mãc de salvação, ou tendo a colneia uma mestra infecunda, isto é, que já não póde pôr ovos de obreiras mas só de zangãos, o unico remedio que ha $e ́$ ir enriquecer com clla outra que d'isso precise, obtendo-se assim uma colonia valente e apta para fazcr magnifica colheita.

Como ó sabido as abellas de cadil colmeia teem um cheiro caracteristico, que as distingme umas das outras, cliciro que é devido ao aroma especial das respectivas rainlıs.

Portanto a primeira cousa que ha a fazcr quando se quer 
reunir dous enxames, é dar-lhes o mesmo aroma; para isto, na vespera da reunião, colloca-se no interior de cada colmeia uma bóla de naphtalina, ou uma perlra de camphora, ou, una hora antes da operação, borrifan-se as abelhas com xarope de assucar aromatisado com essencia de hortelĩ-pimenta.

A remuião deve fazer-se nos mezes de março e abril, ao cahir da tarde, para evitar a pilhagem, isto é, o assalto ás provisões de mel. Se ambas as colonias estão fracas mas teem mãe, procuram-se estas e supprine-se a mais vella e já esgotada; no caso de se não saber qual das duas abelhas mestras é a mellor, deixa-se ás obreiras o cuidado de sacrificarem aquella das mães que llies não agradar, no que geralmente procedem com o maior criterio.

As duas colonias devem ser mudadas para uma colmeia nova, aproveitando-se, sempre que seja possivel, os quadros que tiverem creação, sendo indispensavel não esquecer de os agrupar ao centro; esta colneia colloca-se n'uma mesa coberta com 1 m lençol ligado por um dos lados á entrarla da colmeia, e, sobre este lençol, despejam-se as abellias das duas colmeias a supprimir, sacudindo-as cuidadosanente com uma penna de perú ou pato. Estas abellıas encaminliam-se logo para a nova casa, dentro da qual estão em menos de uma hora.

Se se tiver de reunir a uma colonia com rainha outra que a não tenha, ou só possua algumas obreiras fecundas mas uão fecundadas, e produzindo por isso apenas oros de macho, não é preciso procurar supprimir estes sères prejudiciaes. As obreiras da colonia com mãe encarregam-se d'isso, pois taes especies de abellas fecundas só virem em colmeias onde não hourer mãe, ou onde esta se tormon infecunda e portanto produzindo tamben apenas machos.

Havendo a conveniencia de juntar duas colonias sem mãe, reunem-se pelo processo que indicanos, e, no momento em que as abelhas estão agglomeradas no lençol, polvilham-se levemente de farinha muito fina, e introduz-se-lhe no centro a mestra tambem polvilhada, que ellas acceitam logo, sem a menor reluctancia. 
Tambem se the póde dar a mãe dentro da gaiola propria para tal fim, operando entĩo segundo o processo que já fizemos conhecer.

Se depois de remidas as duas eolonias hourer lucta, deita-se-lhe um poneo de fumo, o que immediatamente as fará soeegar e entrar ua ordem.

Tambem é conveniente, depois da reunião, alimentar as abelhas durante oito dias, afim de thes farorecer a construeção das eellulas para que a femea mãe possa logo começar a postura.

Nunea se deve reunir dous enxames em uma eolmeia pequena, risto que é indispensavel, para o bom desenvolvimento de tão prestimosos inseetos, uma easa grande e ben rentilarla. Una mestra põe na força da postura tres a quatro nil ovos por dia; como o espaço de tempo que deeorre entre a postura e a sahida do inseeto perfeito do alveolo, é de vinte e $\mathrm{um}$ dias, sĩo preeisas setenta mil cellulas vasias para uma postura regular, o que de per si elama bem alto a favor da habitação grande, ampla, onde não haja, por falta de espaço, estorvo a uma boa postura da abelha mãe.

A passagem das abellas de uma colmeia fixa, do nosso detestavel eortiço, para uma eolmeia morel, apesar de se poder fazer todo o anno, deve tambem realisar-se no começo da primavera, quando a ereação ainda é pequena.

Esta operação, faz com que a colonia progrida espantosamente, exeitando-lhe fórtemente a sua actividado.

Procede-se eomo deixamos apontado para as eolmeias moreis, eolloeaudo unı d'estas novas habitações na extremidade de uma mesa larga, um ponco mais alta, visto as abelhas tenderem sempre a subir, e ligando á abertura um lençol, formando lampa, lençol que deve eobrir o resto da mesa. Um quarto de hora antes de eomeçarmos o trabalho, deita-se um poueo de fumo dentro do eortiço para farer eom que as abethas se abarrotem de mel, e untam-se as paredes internas da colmeia movel com xarope ou agua e mel. Despejan-se depois as abelhas sobre o lençol, batendo ragarosa e cadenciadamente 
110 cortiço, e, por ultimo, tira-se o tampo a este, e, com jactos de fumo, obriganı-se a sahir as retardatarias occupadas a dar assalto ao mel.

Se o cortiço a mudar estiver con bastantes faros conı mel procede-se d'outra fórma. Volta-se o cortiço clieio, de bôca para o ar e pousa-sè en cina um cortiço rasio. Batc-se cadenciadamente no cortiço cheio até todas as abellias passarem para o vasio, que, por ultimo, sc despeja eln cina do lençol.

Despejadas no panno as abelhas, com as barbas de una penua de pato guiam-se para a entrada da nova colmeia, sendo curioso rêl-as caminhar methodicamente, umas após outras, até ficaren todas installadas na nora habitação. Quenı as vigiar attentamente rê a abellia mestra entrar na colneia, e, após ella, algumas obreiras scguirem vertiginosamente atropellando-se.

Quando tiverem entrado, o que leva de quarenta a sessenta minutos, desfaz-se o cortiço e aproveitam-se os faros com creação, que se introduzen em quadros, havendo o cuidado de verificar que as cellulas fiquem sempre voltadas para cima, isto é, que a sua base scja menos elevada que o orificio, prendendo-os com um arame nunito fino, que se lhe passa á volta nas extremidades.

Basta que o arame apenas os ampare, pois as abellias fixam-os depois cuidadosamente. Estes quadros com creação collocam-se no centro da colmeia, e o espaço que fica enchc-se com quadros com cêra moldada. Em seguida dispõe-se a nova colmeia no logar occupado pelo cortiço, afim de recolher as restantes abellas que sempre ficam dispersas.

Não deve esquecer, dcpois da passagen, alimentar as abelhas durante oito dias com xarope de assucar ou nel dissolvido em agua.

Langstrotl indica o scguinte processo, que nos parece magnifico, para a passagem de um enxame, processo que aprendeu com Heddon, tambem notarel apicultor americano.

Um pouco de tenipo antes da enxamagen, faz-se passar a rainha e uma parte das obreiras para a nova colmeia, cheia de 
quadros com eêra moldada; a qual se colloea no logar da antiga, que deve fiear dous ou tres metros atraz.

Vinte e um dias depois d'esta prinıeira traspassação reunem-se as primeiras ás restantes abelhas da colmeia relha, onde não fica então señ̃o mel e pollen, visto a ereação estar toda nascida. D'esta fórnı não se perde uma só obreira, ficando a colmeia excessivamente fórte e populosa. 


\section{A alimentaçño artificial}

Quando se introduz um enxame em colmeia nova, on se faz a passagem de uma colonia, é necessario fornecer-lhe, duraute dias, alinıentaçăo artificial, assim como o ó tambem na primarera, quando a colmeia está fraca, e no inverno, quando as abelhas não teen as provisões precisas para poderen passar bem o tempo frio.

Para que a postura da primavera seja constante e em abundancia, é indispensavel uma alimentação certa e regular, assim como o é no inverno, para que as abellas possuam o calor necessario para arrostar os frios excessivos da epocha.

As abellas durante o inverno consomen pouco. Uma colmeia fórte gasta approximadamente seiscentas grammas de mel por mez, mas na primavera, com a creação, necessita de muito mais, visto que, faltando-lhe o alimento preciso para manter a temperatura normal, as abethas teem de abaudonar os faros, que até então cobriam, chocando a creação, para se agglomerarem afim de obter calor, o que faz com que a terrivel loque, que é a cholera das abelhas, invada a colneia, - destruiıdo-a em curto espaço de tempo.

Portanto, quer 110 inverno, quer na primarera, é preciso risitar-se as colmeias e verificar-se se a alimentação n'ellas contida é sufficiente para as respectivas colonias. No caso do 0 não ser não deve haver a menor hesitação em lh'a fornecer.

Se se possuir favos com mel, introduzem-se na colmeia, 
pois é o que ha de melhor, mas na sua falta recorre-se aos xaropes, ao mel misturado eom assuear e ao assuear candi.

Os xaropes e assueares derem ser dados ás abellias só á tarde, e mence de manhĩ on durante o dia, na força do traballo, e, sempre que seja possivel, dentro da eolmeia, ao cimo dos quadros, para evitar a pilhagem.

As abelhas, como nós os tristes humanos, são susceptiveis de se tornarem riciosas, e uma vez fóra do eaminho digno e recto, difficilmente se regeneram. Assim as abellas que se habituarem ao roubo e á pillagem, abandonam a colheita dos eampos, o doce neetar das odoriferas flôres e entregam-se ao assalto das outras eolmeias, para se saciarem de mel, eausando o desespero e a ruina das atacadas, qne, vendo-se perdidas, fazem eausa commum eom as assaltantes e, pela sua vez, transformam-se em ladras tambem.

Para evitar este mal muitos apienltores, em logar dos xaropes, estão empregando o assuear eandi, que introduzenı na colneia, suspenso por finos arames, ao eentro dos quadros. Este assuear, que as abclhas saboreiam gulosamente, prepara-se da seguinte fórma: Dissolve-se mma dada quantidade de assuear em agna e far-se ferver vagarosamente até que a agua crapore, nexendo sempre para que não queime, o que estragaria o preparado e seria muito prejudieial ás abelhas.

Quando, mergnllando um dedo en agua fria e depois latpidamente no assucar, a substancia que adherir ao dedo fòr quebradiça, está o eandi prompto. Deita-se cntĩo em uma rasilha, larga mas pouco alta, eujas paredes foram prériamente untadas com manteiga fina, e. deixa-se alli erystallisar, o que tem logar logo que acabar de arrefecer.

Scholt\%, apicultor da Silesia, reeommenda muito o preparado segninte eln vez do assucar eandi: Aqueee-se meio litro de mel e, logo que estirer quente, junta-se-lhe dous kilos re assuear em pó, misturando bem as duas substaneias. Tira-se depois do lume e eorta-se aos pedaços enrolvendo-os em um panno fino de linho, e introduzem-se nas colmeias suspensos entre os quadros. 
A alimentação liquida faz-se por meio de xaropes que derem ser mais espessos no inverno e mais liquidos na primavera, pois então as abelhas necessitam de maior quantidade de liquidos para dissolrer o pollen com que alimentam a creação.

Tambem ó convenicnte juntar a todos os xaropes um pouco de sal, ou mesmo pôr ao alcance das abelhas agua salgada, dissolvendo uma boa mão cheia de sal $\mathrm{cm}$ dous ou tres litros de agua, pois as abclhas são muito vorazes por o sal, indo procural-o aos esgotos ou aos nuais immundos 'logares onde o pódem encontrar.

A proporção usual de xarope é de cinco kilos de assucar para tres litros de agua e uma pitada de sal. Faz-se ferrer

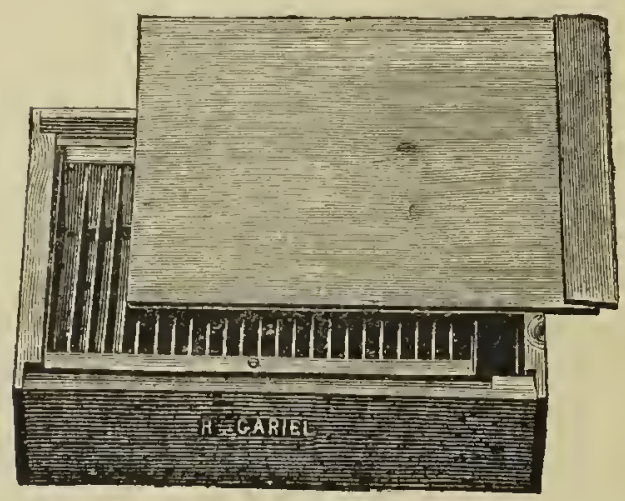

Alimentador rapido tudo, juntando, quando a ebullição estiver a terminar, duas colheres de vinagre para conservar 0 xarope sempre liquido. Isto para a alimentação obrigatoria, quando escasseia a alimentação natural das abelhas.

Para a alimentação estimulante, isto 6 , para a alimentação que se fornece ás abellias na primavera, apesar de ellas terem ainda alimentos sufficientes na colmeia, e que tem por fim activar-lhe a postura e fazel-as mais fórtes e rigorosas, é préciso que o xarope seja muito liquido, empregando-se um litro de agua para dous kilos de mel, ou um litro e micio de agua para dous kilos de assucar e uma pitada de sal.

Quando a primavera é precoce, o que geralmente acontece entre nós, dando então a natureza ás abellias um bom sustento estimulante nos renovos dos salgueiros e arrores de fructa, torna-se inutil o formecimento do xarope estimulante.

Langstroth aconselha preparar o xarope para a alimenta- 
Çĩo obrigatoria dissolvendo dez kilos de assucar branco em cinco litros de agua a ferver e reunindo-lhe dous a tres litos de mel.

Mnitos apicultores preparam um xarope misturando to mel um quinto de agua, ou metade mel e metarle assucar.

Estes xaropes a que, quando as abellias estĩo inradidas pela loque, convén juntar uma gramma de acido salicilico por litro de xarope, deitam-se em alimentadores proprios,

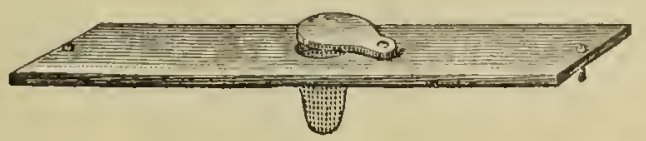
entre os quaes se salientam o alimentador rapido com o interior de lata, podendo conter quatro kilos de xarope e que serve para as applicações durante o inverno, o alimentrulor de cutrada, que se adapta á entrada da colmeia, nĩo impedindo a ventilação nem a entrada e a sahida das abellas, e o alimeutudor aperfeicoado, que mede e regula o consumo do xarope, e que é muito proprio para ser introduzido internamente sobre o centro dus quadros.

A falta d'estes alimentadores póde dar-se o xarope ás abelhas em um prato largo e chato, co-
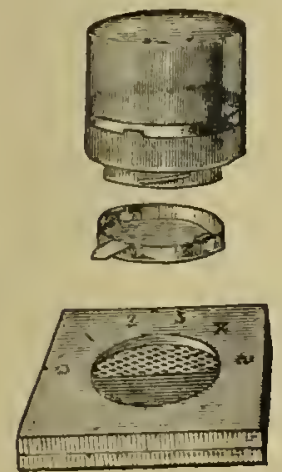

Alimentador aperfeiçoado berto com um panno de linlo muito fino, on cheio de palha triturala, para que as abelhas não se afoguen no liquiclo, ou em uma garrafa com o gargalo fechado primeiro por um panno de linho e rlepois por uma fina rêde de arame, afim de que as abellias não roan o panno e a colmeia fique inundada com o xarope. Esta garlrafa introduz-se na colmeia com o gargalu para baixo, e o peso do ar faz salile o liquido que as abelhas réem lamber. 


\section{A architectura das abelhas}

Quando se introduz um enxame $\mathrm{cm}$ una nova colmeia, as abelhas a primeira consa que fazem é tapar todos os orificios. restindo internamente as paredes com propolis; em seguida principiam a lançar os alicerces do edificio social, isto é, começam a construç̧̃̃o dos favos, conr a cêra, que é apenas o resultado da elaboração no estomago do insecto das materias primas, mel, pollen c agua.

Nas colmeias fixas é sempre na parte supcrior que a construcẹ̃o começa; nas moreis é ao longo dos quadros, em contiInnação das pequenas tiras de cèra moldada, que é geralmente costume collocar nas extremidades, on ampliando os alveolos esboçados na cêra moldada, sc com ella se cnchcı completamente os qualros.

Chegadas da colheita pclos campos, com o estomago cheio, um certo numero de abclhas prendem-se umas ás outras pelas patas trazeiras e ficam assim suspensas em grupos, immoveis, até o mel contido no estomago se lhe transformar em cêra. Obtido este resultado, uma abelha obreira solta-se da cadeia de que faz parte, tira com a escora as palletas de cêra do abdomen e leva-as á bôca, triturando-as com as mandibulas e juntando-lhe ao mesmo tempo um liquido espumoso que lhe dá a ductibilidade necessaria. Então applica a cêra á parte elerada onde dere começar a erguer-se o favo, e continua 0 
traballıo ate se the esgotar o deposito eerifico, sendo logo substituida pol outra abelha, e assim sueeessiramente.

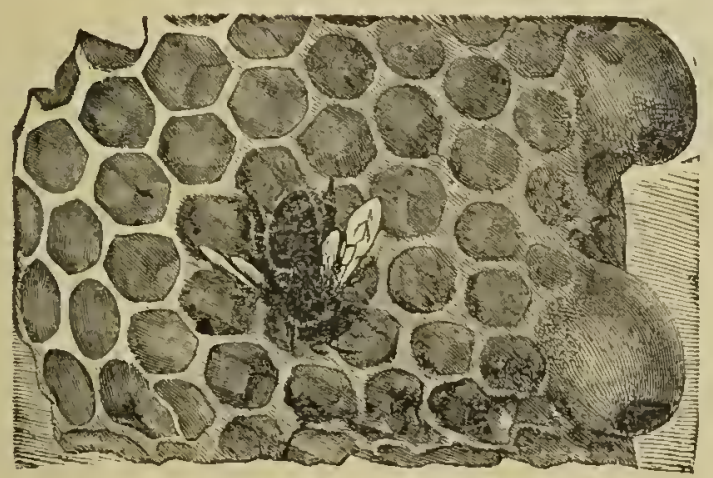

Abelha coustruindo um alveolo. A dỉeita estão alveolos reaes

Reina então na colmeia uma actividade immensa. As abelhas entram e saliem eom uma rapidez vertiginosa, eomo a da torrente que do alto violentamente se preeipita, espumante, sobre os roehedos que lhe formam o leito. As que ehegam earregadas eom o pruducto do diario labutar dão o santo e a senhar ás sentinellas, e penetran em seguida na eolneia, onde são despojadas da earga pelas companheiras solieitas.

E uma agitação rivissima, uma desordem apparente, simplesmente apparente, pois, quer dentro quer fóra da colmeia, está sempre tudo na mellor ordem, desempenhando carla abella o mister que oeeupa na soeiedade. Umas fazem guarda, promptas a repellir qualquer inimigo que appareça, ontras sĩo os delegados de saude que desembaraçam o edificio soeial dos corpos mortos e objeetos prejndieiaes. outras estão enearregadas do systema de rentilação, emquanto as restantes ou andam atarefadas a eolher o mel o o pollen pelos montes e valles, ou segregam ec̀ra. ou aqueem e alimentam a ereação.

Ein rinte e quatro horas de trabalho activo as abclhas obreiras eonstruem quatro mil eellulas; os faros ereseem a olhos ristos, e, em poucos dias, tudo está prompto para receber os oros.

Os faros acham-se geralmente dispostos parallelamente 
entre si, e fixos ás paredes, havendo apenas, entre cada um, um intervallo de um centimetro que são as entradas para a circulação do poro.

As faces dos favos são formadas de cellulas hexagonaes regulares, $\mathrm{nm}$ pouco inclinadas. Não ha vacuos entre as paredes das cellulas; cada parede é commum a duas cellulas, de modo que as seis faces d'uma cellula são as outras seis cellulas que a circuitam. As cellulas das duas faces não são oppostas umas ás outras pois não terminam por fundos chatos, mas simı por pyramides caradas compostas de tres losangos iguaes, de modo que um fundo de uma ccllula pertence a tres do lado opposto. Os lados das cellulas e o fundo pyramidal cavado ó feito assim para economisar cêra. Cinco cellulas de obreiras medem uma pollegada de largura, e uma pollegada de raio contém, em cada face, vinte e cinco cellulas; quatro cellulas de machos, que são maiores que as das obrciras, medem uma pollegada, e uma pollegada quadrada de favo contém dezeseis d'estas cellulas de cada lado. Um decimetro quadrado de faro de obreiras contém approximadamente oitocentos e cin-

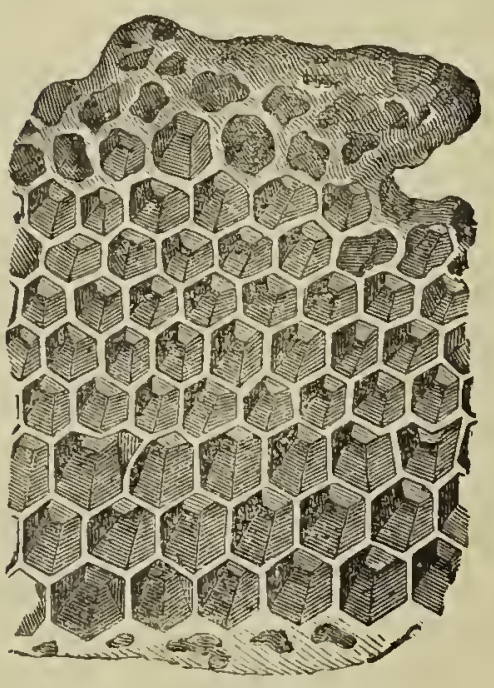

Favo com alverbs irregulares, alveolos pequenos de obreiras e alveolos grandes de machos coenta atveolos, c do faro de machos quinhentos c trinta alveolos.

O vasio das cellulas $\dot{e}$ aproveitado não só para a postura mas tamben para receptaculo do mel. Os bordos das cellulas são reforçados com bordeletes de cèra para resistirem mais.

As cellulas apresentam apeuas tres figuras geometricas, o quadrado, o triangulo equiateral e o hexagono. regular, pois são estas as tres unicas figuras planas que se pódem justapôr sem racuos.

Nos faros ha, cumo dissemos, dous tamanhos para as cellulas lıexagonaes. 
As menores são para as obreiras e as maiores para os maclos; depois da creação fieam torlas indistinetamente para armazenagem de mel e pollen. Além d'estas ha, ás vezes, no mesmo favo, mas quasi sempre nos extremos, eellulas ovoides en fórma de glandes, de paredes espessas, feitas eom eèra sufficiente para dez eellulas de obreiras. São as eellulas

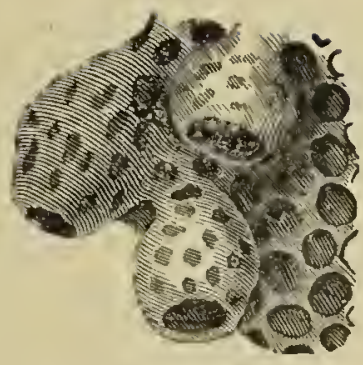

Alveolow de abellia mestina reaes destinadas ás femeas mães. Estas ccllulas tambem appaleeem ás rezes no centro dos faros, formarlas pela destruição de muitas eellulas de obreiras. São entĩo cellulas artificiacs para mües de salvaçuo, quando a femea feeunda morreu e as obreiras tiveran de transformar os oros communs cm ovos de mestra.

Logo que as abelhas mestras sahem das cellulas são estas immediatamente destruidas, para darem logar a cellulas usuaes. As cellulas das obreiras teen uma profundidade normal de doze a treze millintetros, e cineo de largo, e as dos zangãos quinze millimetros de fundo, seis e meio rle largo, o que dá rinte e quatro millimetros de espessura para os alreolos de obreiras e trinta para os de maehos. Quando os alveolos são unieamente destinados a armazenar mel, as abelhas augmentam-os em altura e largura, dando-lhe tambem una leve inclinação para evitar o escoamento do liquido.

Do tamanho da cellula é que depende o tamanho e, ató certo ponto, o sexo das larvas. 


\section{As substancias collidas - 0 nectar, o pollen, o propolis e a agua}

Ao passo que as abellas rão creando a prole occupan-se tambem na colheita do nectar, pollen, propolis e agua indispensaveis para o seu viver animal. Enı todas as flôres que necessitam, para a fecundação, do auxilio dos insectos, encontram-se nectarios, isto é, pequenos orgãos situados gerahmente no fundo das flôres, algumas rezes nas petalas, ou formando verticillos especiaes de folhas transformadas, orgãos que segregam o nectar.

0 nectar abunda com o bom tempo sereno e pouco liumido; o vento norte e o tempo frio obsta á scereção, assim como depois das cluvas as flôres nĩo dão nectar, excepto as pendentes.

O nectar é um liquido incolor, mais denso que a agua e completamente ueutro aos reagentes. Encerra setenta e sete por cento d'agua e partes quasi iguaes do assucar incrystallisarel e assucar crystallisavel.

0 nectar não possue gommas nem glucose livre.

As abelhas além do nectar, tambem colhem substancias assucaradas segregadas por varios vegetaes tacs como os rebentos dos carvallos, salgueiros, faias e freixos, e

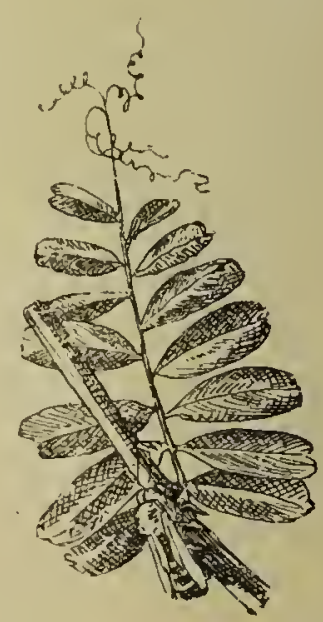

Abella lambendo o nectar ma base de una folha de ervilhaca 
mesmo as secreções provenientes das picaduras de alguns insectos n'estes mesmos vegetaes.

O pollen das plantas,

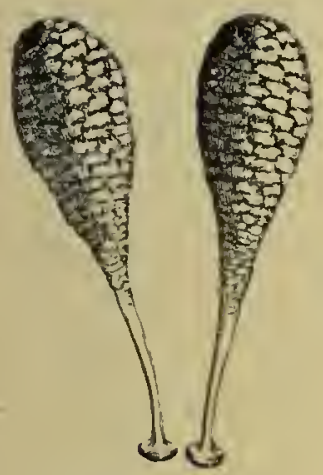

Massa polliuica

da Orchis mentate é constituido por os granulos fecundantes machos, contidos nos saccos pollinicos das antheras e que são mais on nrenos riscosos em virtude da cêra de que se acham untados.

O pollen sêcco das urtigaceas, gramineas e cyperaceas não é colhido pelas abelhas. Os grĩos do pollcn são brancos,

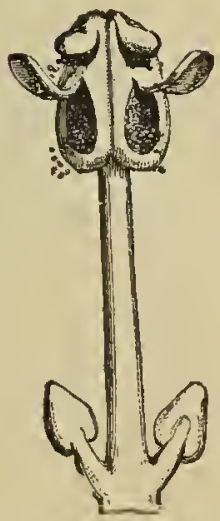

Anthera do lonreiro com os sens saccon pollinicos

vermelhos, amarcllos, negros c bronzeados. Compõem-se extc-

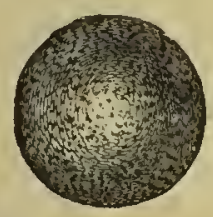

Grĩo de pollen

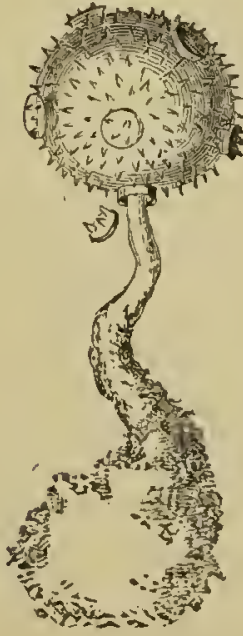

Grũo de polleu do melũo

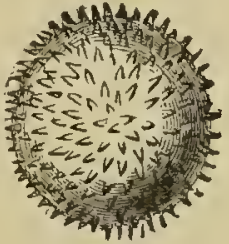

Grão de pollen da alcea

riormente de cêra conglutinante analoga ás cèras vegetaes, e interiormente de uma materia gorda hydrocarbonada, d'um oleo gordo hydrocarbonado, de amido, e um protoplasma viscuso e azotado. $O$ amido $\theta$ a materia azotada são as partes 
essenciaes da alimentação animal e as indispensareis para 0 desenvolvimento da larva.

As abethas collem o pollen na primavera e conduzem-o, reunindo-o, como já dissemos, em pequeninas espheras nas' cestas das peruas posteriores. Segundo Reaumur uma colonia fórte póde colher e gastar cincoenta kilos de pollen por anno.

Qnando acaba o deposito de pollen em epocha em que não pódcm fazer nova colheita, por não estarem ainda abertas as flôres, as abelhas aproveitam então as farinhas de varias leguminosas e gramineas, para alcançarem as necessarias substancias amylaceas e azotadas.

Póde-se-lhe, n'essa occasião, fornecer artificialmente farinha de ervilhas, lcutilhas, trigo, areia, etc., que se colloca em um prato, ao sol, em logar abrigado. Convém misturar

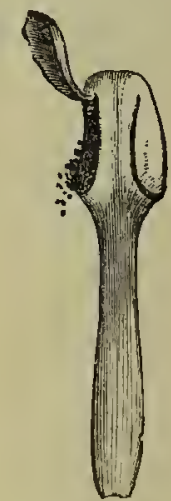

Estames lançando miriades de grãos de pollen a fariuha com serradura de madeira, pois assim torna-se mais facil ás abelhas o apanhal-a sem ficarem sujeitas a moŕrer asphyxiadas na farinha.

Ignoron-se por muito tempo o emprego que as abelhas davam ao pollen. Hunter foi o primeiro que aventou que elle poderia servir para sustento da prole, conjectura esta que Huber transformou n'uma realidade.

Sabia-se por experiencias cuidadosas que, se o mel era indispensavel á producção da cêra, não acontecia o mesmo com o pollen.

Logo para que colhęriam as abelhas tanto pollen senão para o sustento da colonia?

Um dia Huber colloca n'uma colmeia fechada, onde havia mel e agua, abelhas obreiras com favos e ovos; nos dous primeiros dias ainda as abelhas cuidaram da prole, mas, no terceiro, arremetteram desesperadas de encontro á porta, forcejandio por sahir, o que só lhes foi concedido no quinto dia. o enxame todo voou direito ás flôres que estavam mais pro- 
ximo, onde activamente procerlen á colheita do pollen. Examinados durante este tempo os alreolos, nenı uma só larra estara riva; todas tinhan morrido á fome. Ao mesno tempo n'outra colmeia, nas mesmas condições, onde só tinham posto agua e pollen, as abellıas não fizeram csforço algum para saliir, continuando sempre a cuidar das larras, que se foram descuvolvendo cono se as obreiras estivessem em toda a sua plena

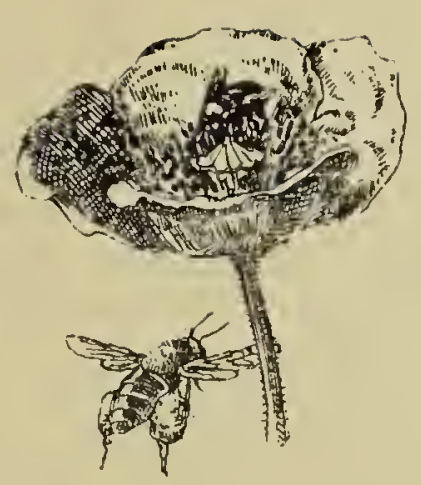

Uma abelua colhendo pollen na flor da paponla, e outra voando já coun pelotas de pollen nas cestas das pernas trazeiras liberrlade.

Logo as conjecturas de Hunter e Huber eram uma verdarle e o papel que o pollen desempenlıa na colmeia acha-se inteiramente determinarlo.

O propolis, a terceira das substancias regetaes colhidas, 0 una materia riscosa, d'um pardo amarellado exhalando ao minimo calor um aroma semelhante ao benjoim. O propolis é duro ao frio, mas amollece com o minimo calor; e arde facilmente, lançando vapores odoriferos. O alcool dissolve-o en parte e dá-lhe un colorido vermelho escuro. É geralmente collido uos rebentos dos choupos, salgueiros e olmos, e transportado pelas abelhas, como o pollen, nas patas trazeiras. O propolis, misturado com cêra, é cmpregado pelas abelhas como betune para tapar as fendas da colmeia, impedir o accesso da luz e do ar frio, enrolver os cadareres dos animaes introduzidos na colmoia e que, pelo seu tamanlio, ellas não pódem triturar nem arrastar para fóra, e construir á entrada da colmeia trabalhos defensivos contra os inimigos externos.

Bertrand diz que o propolis, outr'ora muito utilisado na medicina popular, é ainda bastante empregado como reboco, verniz e mastic para enxertar. Na Russia a baixella de madeira, para ficar resistente á agua quente, $\theta$ coberta com um rerniz composto de oleo de linhaça, propolis o cêra. 0 
propolis ô purificado em agua quente com acido sulfurico. Em seguida é deitado no oleo de linbaça quente, nas proporções seguintes: propolis dous, cêra um, oleo quatro.

O oleo deve ter anticipadamente soffrido, durante quinze a vinte dias, o calor de um formo, para passar pelo estado de ebullição. A baixella de nadeira é mergulhada na mistura quente, onde permanece dẹ a quinze minutos, após o que se retira, se keixa arrefecer e se esfrega com um panno de lã afim de ficar excessivamente brilhante.

Por ultimo, é muito conveniente que, proximo do colmeal, haja agna, de que as abelhas se possam utilisar, mas disposta de fórma que ellas não possam n'ella mor'rer afogadas. Para isto deitam-se, em uma tina baixa, mólhos de palha, ou quaesquer substancias fluctuantes, plantam-se em uma pequena taça plantas aquaticas e em especial agriões, onde as abelhas pousam e d'onde, sem perigo, pódem lamber o liquido, ou cobre-se a rasilha, que contóm a agua, com un panno assente sobre o liquido.

A agua é indispensavel ás abelhas para dissolver o mel crystallisado nas cellulas e para humedecer o pollen com que alimentam a creação.

Segundo Langstroth quarenta colmeias cousumiram, de 10 de abril a 31 de julho, cento oitenta e sete litros de agua, tendo n’um só dia absorvido approximadamente sete litros do mesmo liquido. 


\section{As substancias produzidas - 0 inel}

As substancias produzidas pelas abellas, isto é, o mel e a cêra, são o resultado modificado das substancias collhidas.

O mel, elaborado no tubo digestivo das abellias, é o producto exclusivo de substancias assucaradas. Se a abelha se nutrir só do nectar das flòres o mel ć aromatico e magnifico; mas se absorver tambem residuos assucarados, on xaropes de assucar; o mel ó desprovido de aroma. É por esta razão que o mel produzido pelas abellas estabelecidas proximo das fabricas de refinação, não tem cheiro e é muito mais liquido que o mel dos montes.

O mel, á medida que rae sento collido, ó armazenado, a partir da parte superior da colmeia, o mais perto possivel da creaç̃o.

Geralmente o mel não é deposto na cellula pela abelha que o colleu, pois esta, mal chega, passa-o para uma nova companheira que tenlia o estomago vasio, e parte a continuar a apanha nos campos.

O mel contém varias materias assucaradas. Encontra-se n'elle glucose, assucar de mel, alguma saccharose, um acido live formado no corpo do insecto, e que serve para operar as transformaçoes do assucar crystallisavel em assucar de mel, una materia córante amarclla analoga á cèra, substancias aromaticas, substancias gordas e algumas materias azotadas, prove- 
nientes da presença do pollen; são estes principios azotados que farorecem a fermentação.

O mel, ao ser guardado pelas abcllas nas cellulas, leva ainda comsigo bastante agna, pelo que as obreiras activan então a ventilação da colmeia, fazendo uma maior corrente d'ar, desde a porta até ao interior. Assim que o mel está en estado de ser conservado, as obreiras, depois de llie terem addicionado o preciso acido fórmico, cobren as cellulas cheias com um operculo de cèra, chato, cm opposição aos operculos da creação, que são conrexos.

O operculamento do mel tem por fim amadurecel-o, isto é, fazer collı que soffra na cellula as precisas modificações chimicas que o tornam duradouro. Quando se extrahem faros cujo mel ainda não está maduro, é conveniente deịxal-o nos faros até elle ficar proprio para ser aproveitado, ou deital-o em frascos d'onde se tira a parte aquosa que rem á superficie; se isto não fòr feito o mel fermenta rapido, estragando-se em pouco telipo.

A parte aquosa que salıc do mel, póde ser dada ás abelhas como alimento.

Os operculos de cèra que cobrem as cellulas do mel são inipermeaveis?

A este respeito escrere Langstroth o seguinte:

*A qucstão apcsar de muito debatida, não reccbeu ainda, até hojc, uma solıção incontestavel. Os operculos das cellulas das clırysálidas, feitos de cèra e de pollen, são, sem contradicção, bastante por'osos para permittir á larva que respire, e alguns apicultores pensam que o mcsinu se dá com os operculos do incl nos favos. O proprio sur. Cheshire, apesar dc estar persuadido que as abellias se esforçam em fazer para o mel operculos que o tapem liermeticamente, diz que não ha mais de dez por cento d'cstes operculos que sejam completamente impermeaveis; comtudo, a descripção que nos dá da causa da brancura dos operculos, brancura proveniente do ar contido cntre elles e o mcl, sem lhe ser possircl escapar, dcmonstra quc os operculos são ao principio tão impermcaveis quanto o póde fazcr uma leve camada de cêra. O facto do mel experimentar na cellula dilatações e contracȩõcs, mostra que contém fermentos que pódem actuar a certa tempcratura, mesmo nas cellulas fechadas. 
A experiencia realisada pelo snr. Cheshire, de mergullar favos eom mel na agrla, para reconheeer se as cellulas são impermeareis, foi tambem repetida por nós com resultado diverso. Estas divergencias de opinião respeito ao mesno assumpto, véem de que os operculos sendo muito delgados e frageis, pódem fender de uma fórma impereeptivel, quando são expostos a variaçues de temperatura fóra da colmeia.»

Ten, por alguns auctores, sido admittida a identidade do mel e do nectar, por o mel conservar o aroma das flòres d'onde $\hat{o}$ extrahido, quando essa identidarle não existe realmente.

A aguardente, apesar le extrahida do viuho ć bem differente d'elle, embora, depois de soffrer as transformaçòes operadas pela temperatura elevada na distillação, conserve o aroma typico do rinho. Unm caso identico dá-se com o mel, cuja proporęão aquosa é muito menor que a.do nectar. O famoso mel do Hymetto tão celebre na antiguidade, e que foi outr'ora cantado por todos os poetas, tirava o sen aroma especial das Labiades muito abundantes n'aquellas montanhas da Asia.

O de Regio na Italia, o de Valencia na Hespanha e o do nosso Douro, devem as suas intensas e preciosas propriedades aromaticas ás flôres de laranjeira e congeneres, que alli constituem o principal pasto das abellas.

Mas, so lia plantas que dão preciosos aromas ao mel, tambem as ha que the commmnicam propriedarles nocivas e até renenosas. O trigo mourisco, a esteva, o Aconytum lycothomme, $A$. napellus, e o Cucculos suberosos tornam renenoso uma grande parte do mel asiatico. Na cclebre retirada dos dez mil, n'aquelle feitu sublime, sem riral atć hoje, e que ainda nos causa allmiração e assombro, deu-se $u$ d'estes casos, que nos é narado pelo heroico chefe d'aquellc memorando exereito, o immortal Xenophonte.

Conta elle que um dia cliegou com os sens soldados a uma aldeia da Colchida, ponco antes abandonada pelos naturaes. Os gregos, semi-mortos de fadiga fizcram alto e resolveram descançar alli uma nonte; na aldeia hariam numerosas colmeias cheias de mel, que foram postas a saque pela solda- 
desca faminta. Mas, d'ahi a pouco, todos os que tinham comido do mel sentiam todos os symptomas de envenenamento, nauseas, romitos, dôres de cabeça e uma fraqueza uas pcrnas que os não deixara conservar de pé, obrigando-os a, estendidos no sólo, gritarem desesperadamente com lôres horriveis no estomago. No exercito reinava uma consternação immensa, pois todos julgavam que os soldados en renenados estaram completamentc perdidos. Este incommodo durou dous dias, findos os quaes os doentes recupcraram a primitiva sande, não morrendo um só!

Toumefort, risitando mais tarde o Oriente, certificon estes factos e attribuiu os referidos accidentes ás abellias colherem o nectar da Aralen e Rhodorlendron ponticum muito abundantes n'aquelles paizes.

Galiano, n'um dos seus livros, assevera que morreram em Roma dons medicos envenenados com mel. Talve\% esse mel fosse colhido nas Kalmia angustifolia, latifolin, hirsuta e Andromeda mariam, de propriedades nociras.

O mel varía de qualidade, com as epochas de florescencia. Este facto, confirmado pcla experiencia, mostra-nos a possibilidade da acquisição de mol medicinal plantando á volta dos colmeaes plantas proprias cujas propriedades beneficas queiramos que deem ao mel. Tambem se póden susbstituir as plantas por xaropes purgativos, collocados junto dos colmenes, transformando assim o mel em um remedio nuito proprio para as creanças.

O mel, que Virgilio considerava uma dádiva do cóo, Plinio a salira dos astros, e Mofet a expectoração das estrellas, é um magnifico e sandarcl manjar que devia figurar em todas as mesas.

Infelizmente, no commercio, o mel completamente puro não é frequente, pelo que se torna necessario uma violenta campanlı contra as falsificações que o desprestigiam, afim de que elle renla a gosar os justos creditos de que é merecedor.

Sabios medicos e especialistas illustres teem em todas as 
epochas tecido os maiores e mais calorosos elogios ao uso do mel.

A Abcille Bourguignome enton assim o seu enthusiastico hymno ao delicioso producto das boas abellas:

«O mel, que na antiguidade sulistituia o assucar, formava 1 m ramo tão importante da alimentação que todas as narrativas religiosas los antigos poros fazem d'elie menção. Era cutre os antigos o sustento celeste, a mais pura e a mais importante alimentação dos denses. Offcreeiam-n ás divindades snperiores e constituia especialmente a offerenda destinada aos denses infcrnaes.

Deitavam-o ıa cóva para purificar os manes dos mortos e esfregaram eoun elle a bôca do defuncto, para adoçar Cerbéro on o gnarda dos infernos.

O mel servin sempre para sustento dos sìres divinos; foi assim, dizem, que Jupiter educado eom mel, em signal de reconhecimento, deu an producto das abelhas a rirtude de tornar os ollos claros e puros.

A my-thologia egypeia ensina-nos igualmente que o mel era empregado nos maiores saerificios do Egypto. O mais antigo manuscripto dos egypcios é, sem dusida alguma, o papmmus, que trata de medicina, e que, conscrvarlo ontr'ora no templo de IIempiris, se encontra an presente ua Bibliotlicea Real de Berlim. Vê-se, u'este eseripto, que a mais alta sabedoria dos egypeios consistia em preparar o mel para fazer com elle remedios salutares eontra muitas doenças.

Voltemo-nos agora para os hehrens. As sagradas Escripturas dizem-nos que o patriarcha Jaenb envion mel de presente an govemador Egypeio. Para exaltar a Terra da promissĩo, representaram-a como 1 m paiz onde eorriam o leite e o mel. Embora não existisse mais nada, bastava esta citação para mostrar a grande importancia do mcl entre os helrens.

Ias ha mais: na historia da revolta da Corèa os cliefes da sediçĩo censuraran da segninte fórma o divino icgislador: Não é bastante o ter-nos tiralo do paiz onde correm o leite e o mel? E MLoisés, para apaziguar os rcheliles, recorda-lhe os termos da promessa:Haveis de herdar muna terna onde correm o leite e o mel. - Esta linguagem a respeito do mel é repetida trinta $c$ oito vezes na Biblia.

Segundo as eitarões liblicas o mel não era para os lichrens uma gulodice de que se podia prescindir em easo de necessidade, mas sim, pelo eontrario, seguudo numa citaçio particular da Biblia (Siraeh $39 \mathrm{e}$ 31), III alimento importante.

O mel era para o lebren tão indispensavel como o leite e a farinha. Cousideraram-o $\mathrm{nm}$ alimento dos mais delicados, comparado 
ao maná, que os seus antepassados tinham comido no deserto, como sustento vindo do céo. Dava áquelle poro força na fadiga e na fraqueza; constituia o sustento das creanças e offerecia-se aos hospedes que se desejara receber com honras.

0 mel tiula entre os hebrens uma importancia commercial, por isso que era um artigo precioso exportado para o estrangeiro. Ezéchiel diz que Jnda e Israel, com o vinho, o azeite e o balsamo, enviavam ignalmente o mel a Tyro, a velha eidade commercial dos phenicios, e deixa-nos perceber que forneciam tambem d'elle ontros mercados.

o mel era o melhor prescnte que se podia dar quando se pretendia attrahir o favor de quaiquer.

É o que fizeram, como é sabido, o patriarcha Jacob e a esposa do rei Jéroboam, que enviou uma cantara de mel ao propheta Ahia, para obter nina resposta favoravel ao filho ferido de mina doença mortal. Quando o israelita queria fallar da excellencia da sabedoria dirina comparava-a ao mel.

O melhor mel passava por ser o que corre de per si dos faros, e de que se faz menção na Biblia.

o Talmut refere que o mel era tambem compregado como remedio contra a gotta. as doenças do coração, o croup, a tosse, para arloçar o rinho, perfumar e cicatrisar as feridas dos homens e dos animaes. Nos artigos 4 e 8 o Talmud declara ainda que os defrandadores falsicam o mel mistnrando-lhe agina e farinha. $O$ que ha de notarel é que entre os antigos hebrens o mel falsificado năo podia, como o mel puro, conservar o mesino nome. Emquanto que o mel puro era chamado Debasch, o mel misturado com agua e farinha tomava o nome de Debasch hasiphim. Na epocha de Christo o mel parece ter sido empregado para a conservação dos mortos, não no proprio culto judaico, mas por Herodes $1 .^{\circ}$, estrangciro detestado, que conservou sete annos no mel Marianna, tanto a amara, mesmo depois de morta.

0 mel symbolisa para o Arahe a remiăo da magnificencia e da sumptuosirlade do Paraizo, a syuthese do mais puro sustento celeste.

Assim, representa na vida d'este povo, deste os tempos mais remotos até ans nossos dias, $11 \mathrm{~m}$ papel historico. - "Come mel mell filho, diz Mahomet no Alcorão, por isso que o mel não é só $11 \mathrm{~m}$ bon sustento mas ainıla $\mathrm{nm}$ remedio muito util contra variadas doenças.» - Lế-se no coligo d'Istam que $\mathrm{nm}$ homem reio ter $11 \mathrm{~m}$ dia com Mahomet e the conton que o irmão estava flagellado com violentas dôres no corpo e prestes a morrer. O propheta aconselhou-o a que lhe désse mel. 0 homem seguiu o conselho, mas, passado tempo, 
volton a Mahomet e eonton-lhe que o remcdio indicado parecia ter angmentado o mal. O propheta responden-lhe - "Volta e dá a ten irnão mel, ainda mel e sempre mel, por isso que Deus disse a verdarle e o corpo de telı irmão mentin.»

E o doente, depois de ter seguido os conselhos do propheta, sentin bem depressa rcnascer n'elle a força e a saudle.

Segundo a crença dos maliomctanos, os justos, em seguida á resurreição, deliciam-se com mel no Paraizo. A erença dos mussulmanos eollocou tambem as abellas no Paraizo, por isso que sem abelhas não h่a mel e sem mel แão ha Paraizo.»

Uma consideradissima rerista franceza tecia, não ha muito, os seguintes elogios ao mel:

«Os gregos misturaram mel ao rinho, e prepararam eom elle nma bebida deliciosa cuja reccita se perden. Os luctalores e os athletas da Grecia e de Roma não entravam nunca na arena sem terem absorvido uma grande quanticlade de mcl. Pythagoras sustenta ra-sc eom um pioo de esprecic na persuasão que era cstc um meio infallivel de prolongar a existencia e conservar o espirito sc̃o. Democrito, que morren com cento e nove annos, e Anacreonte, que attingin a idale de ecnto e quinzc annos, attribuiam a sua longevidade ao uso frequente que faziam do mel. Hippoerates, o celebre medieo da antiguidalc, proscrevia o uso do mol áquelles que descjavam uma longa existeneia, reeeita que the deu a elle proprio o mais fructuoso resultado, pois morreu velhissimo.»

Froissard, o celebre apicultor francez, diz:

"O mel exeeree sobre a sande uma faroravel influcncia, o que se eoncche perfeitamente attendendo á sua origem c composição. É indieado para eombater differentes affeeções, sendo muito de aconselhar 0 sen uso prineipalmente para as ereanças e pessoas delicadas. Faz parte do men frugal ordinario: absorvo uma eolher on dnas no fim das minhas refeiçōes, eom un bocalo de pão, e bebo por cima meio copo de agua. É uma infusão por excellencia. Experimentae este regimen, earos leitores, e rereis como ros daes perfeitamente com elle.»

O abbade Voirnot, o enthusiasta propagador das virtudes do mel, escrere a tal respeito:

"Julio Cesar jantando eom Pollion Rumilius, para festejar o annirersario do sen centcsimo anno, pergnntou-lhe quic meio tinla empregado ${ }_{7}$ para conservar o vigor de eorpo e de espirito que possuia. Pol- 
lion responden-1he:- "Interius melle, exterius oleo"-mel para o uso interno, azeitc para o uso externo.

Todo o mundo conhece o quadro que representa S. Martinho a carallo, partindo o manto com a espada e dando a $11 \mathrm{n}$ mendigo a parte maior; o que porém é mellos sabido é que elle accrescenton:«Tu tens fome, disse desprendendo da sella o pesado alforge, toma pois e come; bebe tambem um trago d'este hydromel para te aquecer.» Estara-se então no inverno c a neve cahia en espessos flocos.

A lenda accrescenta que o céo se abrin para contemplar este generoso auto de caridade, e que as nuvens pardacentas se desviaram bruscamente para dar logar ao mais radioso sol que nunca illuminou um dia de verão. D'ahi a expressão o verũo de S. Martinho.

Em uma epocha mais recente, no seculo XIII, nas mesas dos ricos, serria-se o mel no fim do jantar, como em nossos dias á sobremesa servem os fructos e os doces, dizendo-se no momento en quc o mel passava de mão em mão: "Eis mel e quc Deus nos dè sande!»

Uma amavel castellã, originaria da Hollanda, onde o chá é de nso diario, offerecia uma tarde uma chavena da beberagem donrada a $11 \mathrm{~m}$ dos sens caseiros, que tinha vindo pagar-llue a renda: "Obrigado, senhnra. - disse elle - mas não estou doente.»

Ás pessoas que, da mesma fórma, acreditam que o mel só é bom para os doentes, Newman responde:

«É uma ideia lrastante corrente que o mel é um objecto de lixo, não possuindo nenhum principio nutritivo. É $11 \mathrm{~m}$ erro. O mel é um sustento concentralo; não faz crescer os musculos como o biffe, mas possue ontras propriedales não menos necessarias à sande e ao vigor intellectual e physico. Augmenta o calor do systema, excita a acção nerrosa e dá rigor a todas as funcẹões ritaes. Ao operario dá energia, ao homen de negocios força mental; os selus effeitos nào se assemelham aos dos outros estimulantes taes como os alcoolicos, etc., mas exercem uma aç̌̃o salıtar cujos resultados agradareis e duradouros, são una amarel disposiçũo e uma intelligencia limpida.»

O sabio medico italiano dr. Dubini, que foi durante quarenta annos director de $1 \mathrm{~m}$ dos principaes hospitaes do Milão, entre outras expressões elogiosas, diz do mel o seguinte:

"Os principios aromaticos e acidos que o mel contém dão-llıe o sabor picante e o perfume que estimulam as glandulas salivares, determinando uma maior secreção, $\mathrm{cm}$ um maior gran do que nenlumna outra substancia assucarada. É assim que faz con que haja na bòca um maior fluxo de saliva, que, sendo engulida com o mel, ajuda a digestão dos outros alimentos, que teem nccessidade de uma transfor- 
mação para se converterem em chymo e em segnida em chylo. O assucar, sc encontra no ventriculo uma quantidade sufficiente de snccos gastricos para operar a sua conversão total, é absolvido como o mel; mas se nio è bem assinilado decompõe-se, fermentando, em virtude da indolencia do estomago, para formar outros elementos, que irritam os intestinos, e sĩo a cansa de numerosos embaraços nas creanças. Em ontros termos, dii-se uma verdadeila indigestão de assueal.

Quando o mel entra no estomago, o acido particular que elle contém une-se aos acidos rastricos, para excitar e favorecel a digestão, excrcendo assim as snas virtudes antisepticas pelas quaes se oppõe ás fermentaçoes gastricas. Porém a sua acçòo physiologica mais importante realisa-se no figado, onde se consomem tolos os principios assucarados que elle contém, os quaes entram em seguida no sang"ue para se oxydarem e produzirem calor. O assucar toma a mesma direcção por as vias hepaticas, mas deve primeiro soffrer a sua conversão cm dextrina e livulose, emquanto que o mel não necessita nenhuma reconstituição cm lazão de conter tanto dextriur cono lérulose, substancias que entram directamente no figado, para de lál passarem a sangue. $O$ mel é pois $m$ alimento essencialmente hepatico e digestivo, produzindo um cffeito laxativo e diuretico.»

Dennler resume assim as propriedades beneficas do mel:

"O mel puro ó $11 m$ alimento são no mais alto grau. Não exige trabalho especial de ensalivaçĩo e de digestão estomacal, por isso que tem já, no estrdo natural, todas as condiçōes requeridas para a alısorpção e assimilação, desenvolvendo em nós a saulle c a vida. Dovia pois ser de um uso frequente em todas as familias: comido com pão de trigo é muito agradavel e util á saude. As creancas preferem no pão o mel á mantciga; um kilo de mel terái quasi tanto prestimo comp dous kilos de manteiga. O mel é muito superior em sabor; alén d'isso conserva-se indefinidamente, emquanto que a manteiga se torna rançosa depressa e póde causar então muitos estragos no estomago, taes como vomitos, azia e diarrhéis. A diggestão, que influe tanto no espirito como no corpo, denende principalmente do sustento.

Alimentos de má qualidade causam, em um estomago fiaco, males irreparaveis. 0 mel puro nào occasioni nunci incligestões. Algumas colheres de mel tomadas todas as manhìs ao almoso aquecem e fortificam o corpo. pelo que o recommendamos ás pessoas de idarle arancada, a quem geralmente falta o calor natural do corpo. Para viver muito tempo é preciso tomar cala manhã leite com mel e n'clle molhar o pão. Era este o sustento favorito dos nossos antepassados.

As creanças gostam em geral de mel, mas são sobretudo aquellas 
que, em virtude de $u m$ rapido desenvolvimento do corpo, tcem $\mathrm{um}$ aspecto pallido e definhado, que sabem instinctivamente o que póde fazer-lhe bem, procurando as doçuras e principalmente o mcl. Paes não recuseis a vossos filhos este alimento delicioso que os fortifica, os preserva de numerosas doenças, e lhes procura o melhor de todos os dons - a saude.»

Por ultimo Langstroth, o venerando apicultor americano diz, referindo-se ao mel:

"A historia não falla na primcira descoberta do mel pelos liumanos. Quer o homem primitivo tenha conhecido o mel por um incidente, tal como a fenda feita pelo raio em uma arvore contendo abelhas, quer tivesse notado que varios animaes o comiam com prazcr, é certo que a primeira rez que saboreou este liquido espesso e transparente renceu o receio das picadellas e tornou-se caçador de abelhas. Descle cssa epocha o modo de obter mel, soffreu muitas mudanças, progressos e retrocessos, mudanças que nos mostram os escriptos que sobreviveram. A asphyxia das abcthas para se the extrahir o mel, foi, sem duvida, uma invenção dos seculos das treras, quando a familia humana tinha perdido em apicultura, como em toda a outra sciencia, o saber das idales precedentes, pois no tempo cm que viviam Aristoteles, Varrão, Colunella e Plinio, não existia una pratica tão cruel. Os apienltores então, extrahiam ás abellias o mel que ellas possuiam em demasia, não matando senão as que eram fracas e doentes. Os methodos modernos abandonaram as praticas barbaras, e tempo veio em que o cpitaphio seguinte, tirado de um livro allemão, póde ser collocado no orificio da cavidacle onde as abcllias fôram mortas pelo enxofre:

Aqui jaz

Interrompida no sen trabalho uti?

Uma colonia

De abehlhas laboriosas

Vilmente mortas

Por o seu

Ingrato e ignorantc

Proprietario.

Os methoulos actuaes são tão superiores ans antigos como o rail de aço o é ao caminho lamacento, como o trem de primcira classe o é á diligencia. Todos os esforęos do apieultor devem tender á produeção do mel, e o problcma apicola póde formular-se assim: Como fazer produzir mais mel, com a menor despeza possivel, ás colonias que possuimos?" 


\section{Extracção do mel-Falsificaçồes do mel}

Nada mais defeitnoso e prejudicial ao virer das abelhas do que a fórma por que, geralmente entre nós, ć feita a colheita do mel nos cortięos, colheita a que o vulgo dá o nome de cresta. N'esse momento os pobres dos bons e laboriosos insectos, ou são asphyxiados pelas espessas nurens de fumo de trapo queimado, ou afogados pelo mel que thés inunda o cortiço.

Ha duas epochas de eresta, ou pelo S. Joño, ou no fim do rerão; poucos crestam na segunda quinzena de maio, a melhor epocha para essa operação entre nós, em que se deixa á abelha espaço e tempo para poder fazer a sua colheita durante a estação boa, e reunir os precisos alimentos para 0 inverno.

Quando o proprietario das abelhas, ou em geral o abelheiro, um homem especialnente dedicado ao assumpto e que, por um salario fixo ou por a retribuição da eêra produzida, anda. de casia em easa a extrahir o mel, se resolve a proeeder á operação, tira o tampo ao cortiço, depois de the introduzir uma enorme quantidade de fumo, que muitas vezos asplyxia não só als abelhas mas tambem a ereação, eórta, eom uma faea ou uma colher de ferro, os faros, quando os não arranea eom as mãos, até á primeira ou segunda eruz de pau existente no cortiçu, eonforme a valentia do enxame.

Este processo ó o que la de mais ineonreniente e detestarel, por isso que o mel extravasado, que corre pelas paredes 
internas e pelos favos, afoga muitas abellıas e muita creação, incita as obreiras á pilhagem, prorocando até o assalto das estranhas e, além d'isso, sendo todos os annos extrahida a cêra nova da parte superior, fica na parte inferior sempre uma cêra relha, que se torna negra, e que é facil presa da tinha ou traça das abellus, que tantos estragos causa nos cortiços que invade.

Para evitar isto seria de estimar que se seguissc entre nós o systema dos lavradores allemães, que extrahem a terça parte do mel dos seus cortiços, um anno na parte supcrior e 110 anno seguinte na inferior, pelo qre teem sempre cèra nova e boa.

Dos cortiços nunca é possivel tirar favos perfeitos e apresentareis, como acontece com as colmeias moreis, ou mesmo com as alças moreis que se augmentam ás colmoias fixas, o que cada dia accentua mais e mais a necessirlarle de se pôr de parte o rellıo cortiço, substituindo-o por uma boa colmeia movel, creando assim a apicultura portugueza, que nos ha-de inundar de mol e fornecer cêra que evite a importação annual das centenas de contos que fazenos d'aquelle producto, que tão facil c tão proveitosamentc podiamos obter em Portugal, quasi sem despeza alguma.

As colmeias moreis alóm do grande merito que tecm de permittir que se extraha um favo magnifico de belleza e perfeição, que póde ser servido na mesa mais opulenta, evitan a morte da creação, pois se, no quadro que fờmos tirar, existir alguma creação, ou muitos alveolos com pollen, torna-se cste a collocar no mesmo logar até que esteja em estado de ser aproreitado.

Deixando para o capitulo competente o explanarmos o modo de se obter quadros e sccções com mel, vamos occuparnos, por agora, do meio de extrahir o mel.

Como os faros saluidos dos cortiços são irregulares e véem geralmente fragmentados, desoperculam-se dos dous lados com a faca propria, passando-a levemente á 
superfieie dos favos, de modo que todas as cellulas fiqnem abertas, e collocam-se sobre $11 \mathrm{~m}$ plano inelinarlo. ao sol, eseorrendo para dentro de uma vasilha de ridro, porcellana oll barro vidrado, ou em um peneiro ou eoador de metal. Esecrido o primeiro mel, a que dão o nome de virgem, que 6 o mais puro, limpo e portanto o melhor, espremem-se os favos atravez um pamno de tecido fino, oll na prensa, o que completamente faz sahir todlo o mel que a cêra contiver.

Este segundo mel 6 sempre ordinario, mais earregado na eôr, de má qualidacle, e eom bastante cèra.

O mel das colmeias moreis é sempre igual, em virtude clos faros poderem ser submettidos ao extractor e o mel recolhido limpo de toda e qual-

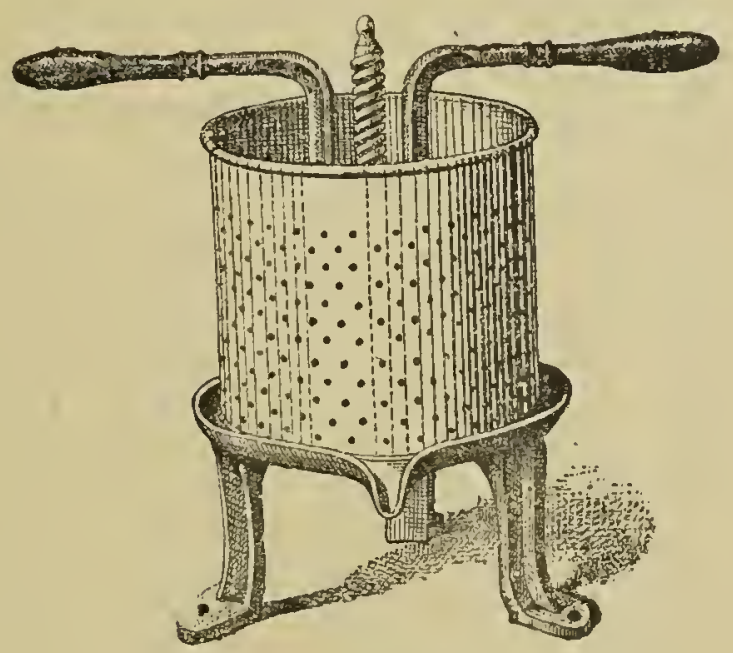

Prensa fala expremer os favos quer impureza.

0 apienltor mobilista preeisa, quando vae fazer a colheita do nıel, de ir munido de um caixão de lata que feehe hermetieamente, para guardar e transportar os quadros com favos,

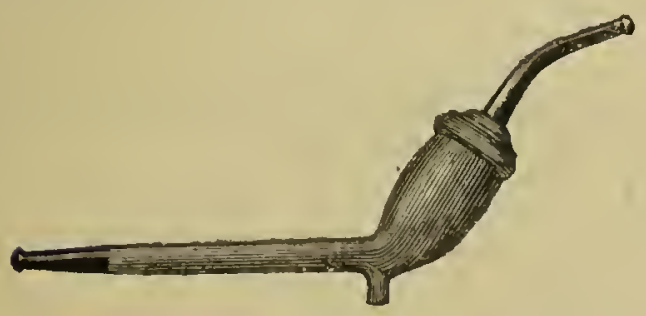

Caehimbo proprio para deitar Pumo nas colmeias un folle para applicar o fumo, ou, no easo de ser fumador, um eachimbo proprio, o que simplifica a operaçĩo, permittindothe ter as mãos livres e poder, a routade, deitar o fumo que quizer na colmeia, uma faea fórte ou ciuzel para despegar os quadros, algumas pennas de perú 
ou pato para limpar as abelhas dos faros, e uma pequena vasilha com agua, para lavar as mãos quando estiverem muito cheias de mel, o que, alćm de causar incomnodo, attrahe as abellıas, difficultando a operação.

Munido com este material, de manhã cedo, ou mellıor á tarde, que é quando ha menos receio da pilhagem, diminue-se um pouco a cntrada da colmeia e procede-se á collıeita. Se temos só a recolher o mcl das alças, levanta-se a tampa e tiram-se un a um os quadros da alça, limpando as abelhas para dentro do corpo da colmeia e guardando immediatamente os quadros, á medida que vão sahindo, dentro da caixa, que se deve fechar logo.

Assim que se tem tirado todos os quadros, projecta-se com o folle, ou com o cachimbo, um pouco de fumo nas paredes da alça, para fazer descer todas as abelhas para o primeiro curpo da colmeia, e, logo que alli estão, tira-se a alça, cobre-se bem os quadros que constituem o primeiro andar com um pamo, e colloca-se a tampa no respectiro logar.

Se na alça ha só secções, e estas, conio deve sempre ser, estaram separadas do corpo principal por a grade de zinco furado, o que não deixa a femea mãe passar e portanto fazer postura nos pequeninos quadros unicamente destinados ă armazcnagem do mel, tiranl-se as secções com as abellas que tirerem e guardam-se na caixa, tapando, como já deixamos dito, os quadros que ficam.

Se pretendermos extrahir algum quadro do corpo principal da colmeia, desviam-se as abelhas com fumo, desprende-se com uma faca ou com un cinzel - quadro, que geralmente está muito adherente ás paredes da colmeia por meio de uma fórte camada de pro-

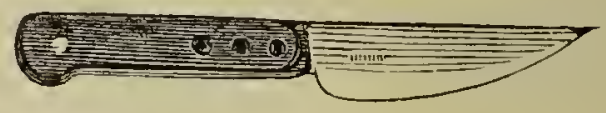

Faca para despegar os quadros polis, limpa-se das abelhas com uma penna, e substitue-se por outro simplesmente iscado ou todo cheio de cêra moldada, conforme se quizer apressar ou não o traballıo das abelhas e o desenvolvinento da colonia. 
Se não houver uma sala proximo, abre-se um pouco distante da colmeia a lata que contém os quadros on secções, tiram-se um a um, limpam-se, com as barbas de uma penna, de todas as abelhas e guardam-se em outra caixa. Se houver sala proximo, transportam-se para lá, e faz-se então a limpeza aos quadros fóra de uma janella, sacudindo com uma penna as abelhas, que seguem immediatamente para a respectiva casa.

Limpos os quadros póde-se-lhe logo extrahir o mel, ou guardar esse traballıo para d’abi a dias. Ás secções raras rezes se the tira o mel, pois rendem-sc perfeitamente assim, visto seren de um attralıente aspecto e magnificas para apparecerem ell ıma mesa.

No estrangeiro é já uma bella fonte de receita para os apicultores a venda de secções com mel, que, sem duvida, lã̃ode ser tambem a tentação do nosso publico quando apparecerem, todas appetitosas, nas exposições das confeitarias.

A cxtraç̧ão do mel convém que seja feita em uma sala bem fechada e longe das colmeias, para evitar que as abellas, attrahidas pelo cheiro do mel, a inradam, assaltando gulosas o delicioso nectar, incommudando e picando o operador; esta extraç̧̃o realisa-se por meio de uma machina propria, quc não só permitte quc o mel saiha puro e sempre igual, mas que os faros rasios d'elle, fiquem perfeitos, de fórma a poderem ser outra re\% restituidos ás abelhas.

Isto tem um alto alcance, pois, sendo na epocha da grando colheita fornecidos ás abelhas os quadros já com os alreolos promptos, em condições de receberem mel, ellas produzem muitissimo mais mel, pois nĩu perdem um tempo precioso na elaboração da cêra e fabrico das cellulas.

A descoberta do Melo-extractor foi derida ao acaso.

O apicultor italiano Hruschlia tenlo dado um pedaço de faro com mel a um filho, este collocou-o n'um prato, que pousou em uma mesa, fazendo-o, por brincadeira, girar com toda a velocidade.

A força centrifuga desenvolvida pelo movimento expelliu o mel dos alreolos, espalhando-o pelo prato e pela mesa. 
Baseados n'este principio da extraç̧ão do mel pela força centrifuga, existem hoje numerosos typos de extraetores de mel, que todos consistem em nma caixa cirenlar de metal com uma abertura na parte inferior para salida ro mel, e tendo, ao centro, uma engrenagem onde se collocal a secção ou o quarlio com os favos desopereulados, e que, por meio de uma manivella, se faz girar rapidamente, projectando assim o mel de encontro ás paredes do appareilo, com um ruido semelhante ao de uma fórte ohuva cahindo $\mathrm{em}$ um telhado de zinco.

Para recolher o mel sahido

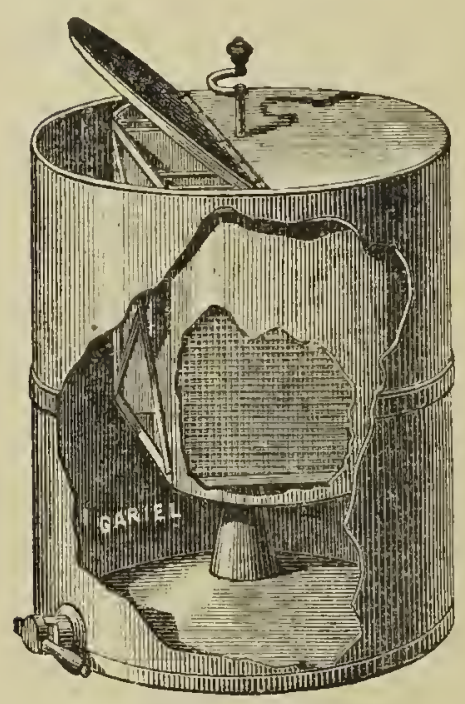

Extractor de mel do extractor, deve utilisar-se una vasillıa de louça vidrada, de vidro ois de folla de flandres, e nunca de madeira, assim como o mel nunea deve ser eonservado senão em fraseos de vidro ou potes de barro vidrado, liermeticamente tapados.

Os quadros com faros vasios só devem ser introduzidos nas colmeias ao fim da tarde, para evitar a pilhagem; as abellas obreiras levan, a limpar de mel e a concertar estes favos, tres a quatio dias. Como todos os generos de grande consumo, o mel é objecto de rariadas fraudes. Misturam-lle assucar, glucose, farinha de millo, de abobora, féeula, amido, gesso e muitas outras substancins, algumas das quaes nocivas, e que transformam aquelle magnifico manjar em alimento prejudieial.

Como é tambem muito apreciado na Europa o mel o mais claro possivel, quasi branco, essa braneura é-lhe artifieialmente dada pelos negociantes da especialidade, que, para isso, 0 expõem á neve, durante semanas, em vilsos opacos e maus conductores do calor.

O mel, quando puro, crystallisa logo que se fazem sentil 
os primeiros frios, aclarando e endureeendo. Para o tormar liquiclo põe-se ao sol, ou proximo do fogo, con o frasco, ou vaso de barro onde estiver, desarrolhado, ou o melhor, mette-se a vasilha que o contiver em banlıo maria.

Quando se submette o mel crystallisado ao fogo, para o liquifazer, é preciso fazel-o de fórma que não aqueça em demasia, o quc the póde causar a evaporação dos oleos essenciaes, dando-lhe um detestavel gosto de melaço.

O mellor meio de conhceer o mel falsificarlo é o sabor; quem uma vez tiver comido mel bom, não mais se cngana.

A juneçĩo do assuear ou da glucosc reconheee-se faeilmente, dcitando em um frasco cincocnta grammas de mel e a sufficiente agua filtrada para o dissolver.

Agita-se bem, e, logo que estiver dissolvido, deita-se pouco a pouco na mistura algumas gottas de alcool puro; agita-se de novo e dejxil-se reponsar. Sendo e mel puro a dissolução fica clara; e turva tendo ghucose ou assucar.

As addições de farinha, fécula e amido descobrem-se facilmente dissolvendo algum mel cm bastante agar, pois as substaneias estranluas formam logo deposito no fundo da rasilha. 


\section{O mel como bebida - o hydromel - O mel no vinho - Vinagre, alcool, cerveja e licores de mel}

Com o mel fabricam-se, desde tempos remotissimos, numerosas bebidas magnificas, entre as quaes occupa primeiro e proeminente logar; o classico hydromel.

Hydromel vem de uma palarra grega que significa agua e mel; era a bebida farorita dos deuses, e, como diz eloquentemente Froissard, «certos poros nĩo conheciam prazer mais suave do que saborear esta bebida pelo craneo dos seus inimigos».

Na mythologia escandinavica os guerreiros, no paraizo de Odin, comiam javali e bebiam hydromel.

Nos paizes do norte, onde o vinho escasseia, ó ainda hoje justamente considerado o hydromel, a mais pura, suave e a melhor de todas as bebidas.

Ao presente, na Europa central, devido ao vinho e á cerveja, não gosa o favor de outr'ora, favor que póde e deve readquirir quando a producção de mel attingir o seu maximo, tornando-se baratissimo em todo o mundo, e ficando assim o saudarel e refrigerante hydromel ao alcance de todas as bulsas, mesmo as mais pobres.

o hydromel, que é excessivamente digestivo, póde ser secco como o Madeira, licoroso como o Porto ou espumoso como o Champagne, e, envelhecendo em garrafa, adquire finas propriedades boas que o tornam estimadissimo. 
Já um velho e raro Tratado historico e figsico das abelhas composto pelo padre Francisco de Faria Aragão, e publicado em Lisboa, pelo grande naturalista Fr. José Mariano Velloso, em 1800 , se occupa detalhadamente do hydromel, dizendo entre outras coisas interessantes o seguinte, que mostra a importancia que outr'ori, mesmo entre nós, se dava ao hydromel, hoje quasi por completo esquecido em Portugal:

"Nos paizes do Norte, aonde naõ cresee vinho, on he muito raro, se usa por bebida eommua a agua mel, esta bebicla, ainda que desagradavel a quem naõ está aeostumarlo, naõ deixa de fazer bom estomago, e sêr sandavel a quem a bebe; dissolve as fleumas, ajuda a digestaó, e he suavemente clinreetica: he aeonselhada rle muitos para o mal da gota, la pedra, iterisia, e geralmente para os velhos.

A agoa mel foi conhecidla dos antigos pelo nome de IIydromel, ou Mulsum; linje na Russia, Curlandia. Polonia, Prussia e outras provincias de Alemanha, se chama Meht. Ella he melhor, on peior, segunclo he o mel, e o modo, eom o qual se faz. Para ordinario, e simples Melıt nsaõ da agoa aeima dita, das lavagens, ou de ontra composta de sorte, que contenha huma parte de mel, e sete, até.oito partes de agoa; esta mistura se coze a fogo brando, espumando sempre, até que se faça elara. O signal de estar eozida, he quando nella nada hum páo, que se lhe lança dentro, on lum ovo fresco, o qual dere fiear na superficie meio dentro, meio fóra; outros a provaõ com lum ferro quente, se elle torna a sahir em hraza he signal de estar mricla: dentro no fervor se lhe lauça luma maõ eheia de huma planta semelhante á madre silva, e que em Francez se ehama houblon, eu nai a tenho aehado por estas terras, os Ingle\%es e Alemães a metem ua eerveja, ella the enmmmica hum amargor, e a eonserva sem se azerlar; onço dizer que se acha em Vizen; em lugar della as flores da arvore Tillic fazem melhor effeito. (O Meht assin cozido se mete em lum pipote, deixando-o aberto, en quanto fermenta, e depois taparlo se eonserva para beber.

O mel, assim enmo tambem as de mais snbstancias regetaes, e doees, he sujeito á fermentaçó em geral, e partienlarmente a espiritnosa; para isso basta dillni-lo eom hastante quantidarle de agoa, e expo-lo a lium grío de ealor sufficiente. Para fazer portanto o bom Mcht, ou hydromel rinoso, mais singular, e agralavel ao gosto, pode servir o seguinte methodo: tome-se limma parte de mel bom, e puro, v. g. lumma canadi, ajuntem-se seis partes, on canadas de boa agna, faz-se tndo ferver mui lentamente a lumn fogo doee, e sem fumo em hum tacho, ou caçoula vidrada, apenas começa a ferver se lhe lança. 
- houblon, on flores de Tillia dentro de hum saqueto, on bolsa de linho, com hum seixo dentro bem lavado, para que desça, e nañ nade em eima; tirem-se as espumas, o o ferver durará até que tenha diminuido hum terço: no fim se lhe pode lançar huma clara de oro, a qual serve muito a separar a espuma; entañ se lhe ajuntaõ algumas especies, e erras cheirosas, v. g. canella, eravo, noz muscada, flores de alfazema, aleerim etc., eouforme o gosto de cada hum; tudo isto em bolsa tambem de linho, e deixado ferver mais algum tempo, e logo coado se deita $\mathrm{cm}$ vaso de púo, ou barro até que pereça o calor. Em tendo arrefecido se enche com elle hum barril, o qual se tiver servido a vinho será melhor, este barril, naõ muito eheio, deve-se colocar em sitio aonde o calor ennstante seja entre os vinte, e vinte oito gráos do Therm. de Reaumur. Os fenomenos da fermentacao com este calor, viráo mais depressa, e depois de acabados se lavará bem o barril para - conservar fresco na allega. Elle sc eonserva, e se faz sempre melhor até hum anno, perdendo sempre mais o sabor do mel, que a mnitos os faz dezagradarel. Póde-se tambem tirar do barril, e encher a garrafa, como se faz com o rinho para o conservar. Durante a fermentaçaó se lhe deixaõ ainda as especies dentro, e depois se tira o saqueto para fóra. Tambem de tempo em tempo se enche o barrilote com huma poręaó de Neht cozido, a qual se cleixa para supprir a quantidade de espuma, que a fermentaçaó lança fóra do barril. Ontra receita reccbi eu de hum Alemão, a qual naö provei: elle conserva a mosma proporçaõ de huma parte do mel, e seis de agoa; fazia ferver da mesma sorte, metia-lhe dentro em logal de houblon, Lumulo dos salgueiros (Lupulus salictarius) on Tinha do norte, botoens de rozas vermelhas: depois de cozido este Meht, fervia á parte huma canada de mel, mexendo sempre até que adquira côr rnça, on rermelha, entao se misturavaõ bem estas duas consas, c the metia dentro bagas de lomrciro pizadas em vez de especics.

Finalinente o embarrilava ete.»

O hydromel fabriea-se con agua, mel e um fermento que transforme o assucar do mel em alcool. Quando a agua é suffieiente para transformar todo o assucar, o hydromel é secco, quando fica assucar para transformar, é licoroso, e quando se lhe addiciona acido carbonico, on substancias que o produzam, é espumoso.

Partindo do principio de que $\mathrm{mm}$ kilo e oitocentas grammas de assucar, depois da fermentação, dão um grau de força alcoolica a um hectolitro de agrua, e sabendo-se que o mel tem oitenta por cento de assucar fermentiscivel, fixa-se que, para 
se obter um hydromel a dez graus, se deve usar duzentas e vinte e eineo grammas de mel, por cala litro de agua, que deve ser de naseente, por cansa dos caleareos que contém.

O mel custa a fermentar em virtude do acido formico que as abelhas the addicionam, exactamente para obstar ao desenvolvinento dos fermentos.

O pollen que as abelhas colhem destinado á alimentação propria e da próle, póde tanbem servir de fermento, para o que se deitam dezoito a vinte grammas d'elle por hectolitro d'agua eom mel; tambem ć cmpregado, para o-mesmo fim, o fermento das uvas na razão de um litro por heetolitro, o fermento de cerveja, as levaduras de rinho selcccionalas, de que basta un deealitro por heetolitro, e com as quaes se póde dar ao liydromel o aroma dos vinhos mais preciosos.

O fermento das uras prepara-se, assim como o dos fructos, colliendo alguns cachos de uras brancas. ou tintas, que sejam bons e perfeitos, sem os lavar nem alimpar, pois assim desappareeeria o fermento rinoso que lhe eobre a pellicula, e pizando-os por meio de esmagamento com as mãos, em uma rasillıa de madeira ou louça vidrada muito limpu.

Logo que tiverem dado todo o suceo passa-se estc por uma peneira de sêla e junta-sc ao hytlromel, ao qual lera os germons bons que o hão-de fazer fermentar como precisa.

Não havendo uras freseas, fementam-se as wras passis, a não se qucrel aproveitar para tal fim os fructos frescos on seeeos, especialmente as eerejas, os morangos, as peras, as maçuis, as amoras, ctc.

Quanto maior fòr a grarluação aleonlica do hydromel tanto mais elle se conserva. É preeiso, porém, haver muito euidarlo cm que a fermentação não seja incomplcta ou irregular, pois em tal caso póde o liquido estragar-se.

Sendo a fermentacão boa eonserva-se indefinidamente, envelheeendo e elegando a riralisar eom o bom vinho vello; mas para isto é indispensarel que possua uma graduação de $13^{\circ}$ a $16^{\circ}$.

O celebre apieultor francez sur. Georges de Layens, resu- 
midamente expõe da seguinte fórma o sel methodo de fabrico do hydromel :

«Em uma rasilla de cem litros, por excmplo, deitam-se vinte e cinco litros de mel, que, se cstiver crystallisado, se põe antes proximo do fogo para o fazer derreter, e setenta e quatro litros de agua. É preciso não encher o tonel, deixando $11 \mathrm{~m}$ vasio approximadamente de ım litro, para evitar que a primeira fermentação faça sahir o liquido da vasilha. Em seguida introduz-se na vasilla cincoenta grammas de acido tartrico e dez grammas de sub-nitrato de bismutho, productos que se eneontram faeilmente á renda. Por ultimo tira-se de uma eolmeia um faro contendo pollen do anno, de que se deita na mistura approximarlanente cincoenta grammas, dissolvidas antes $\mathrm{cm}$ um pouco de liquido tirado da vasilha.

O acido tartrico serve para activar a fermentação, o sub-nitrato de bismutho para impedir as fermentações secundarias e o pollen para forneeer o fermento natural; são pois tres sulsstaneias preeisas para o bom resultado da operação.

Com nm pan mexc-se o liquido bem, c, em segnida, eolloca-se 1 m panno molliado sobre o batoque, e por eima do panno areia molhada.

lieconhece-se que a fermentação, que dura de cinco a seis mezes, está completa, quando, encostarlo o onvido á vasilha, se onvir uma leve crepitação; então substituc-se o panno e a areia por um batoque. D'ahi cm diante, até ser elarificado e engarrafado, não dá mais cuidados.

Se se prova de tempos a tempos o hydromel em via de fabrico, encontra-se-lhe algumas vezes, no fim da fermentação, $11 \mathrm{~m}$ sabor levemente amargo. Isto năo deve causar inquietação por isso que o gosto desappareee eom o tempo.

Póde-se resumir assim este simplicissimo processo:

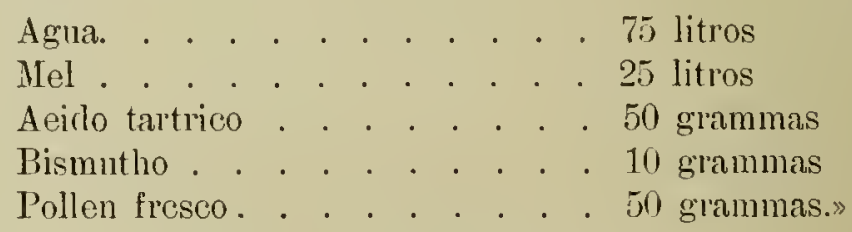

A agua onde se dissolve o mel dere ser morna, mas não a ferver, afim de não matar os fermentos. Com o glucometro Guyot, um pequeno peza-mosto de vidro, toma-se a graduação do bydromel, o que é indispensarel quando se quer aproveitar as aguas de lavagens dos favos, dos extractores, ete., pois elle dá-nos a eonheeer a quantidade exacta do mel que é preciso 
reunir á referida agua de laragem afim de obter um hydromel com sufficiente graduação alcoolica.

Estas agnas de lavagens são geralmente fracas, sendo forçoso a junção de uma porção de mel, para que depois o hydromel se conserve e não se estrague de prompto.

A fermentação do hydromel dura de dous a scis mezes e só depois d'ella acabada é que começa a aclarar, scndo então conveniente clarifical-o con gelatina, claras d'oros, ou tanino dissolrido em alcool 11 proporção de dez grammas por hectolitro do hydromel.

Estanclo limpo e claro é melhor engarrafal-o, pois assim envelhece mais vagarosamente ć verdade, mas muito melhor do que na rasilla.

Se o hydromel fồ sccco, qualquer garrafa serre; mas sendo licoroso é preciso garrafas fórtes afim de que as não rebcnte.

Se so quizel conservar antes o hydromel em eascos, estes devem ser guardados em adegas muito seccas e ben rentiladas, pois nas adegas humidas o hydromcl está sujcito a corromper-se.

T'endo o mel a empregar algum matu sabor, póde este ser facilmente modificado no lydromel, suspendendo durante quinze dias, na rasilla onde o liquido estiver fermentando, um sacco com sementes de zimbro, ou ajuntando ao liquido algumas gottas de essencia de zimbro, dissolvida em alcool, ou fullus de salva transmarina (Sulvin sclarea), ou flòres de sabugueiro, que lhe dĩo o gosto de muscatel, ou hortelì-pimenta, aniz, funcho, canella, noz muscada, coentro, etc.

O snl. Gastine nudificou proveitosamente o processo de fazel lydromel, substituindo por saes as substancias oryanicas e mincries que se encontram nos mostos completos.

Assim junta á agua e mel os scguintes elemcutos uteis:

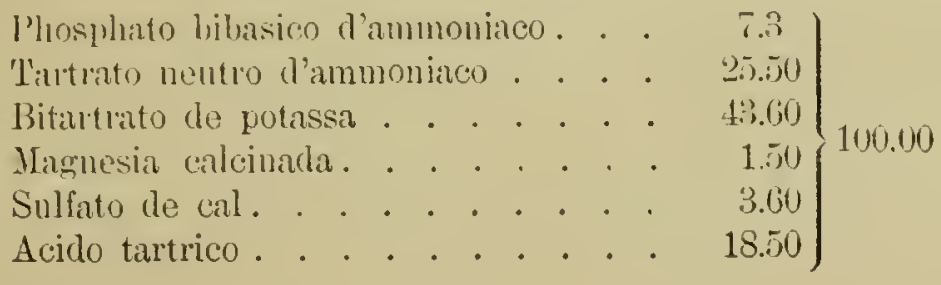


É preciso que os saes sejam puros e bem brancos. Esmagam-se em un almofariz, passam-se por uma peneira fina, e os residnos que ficam trituram-se de fórma que tudo passe. Mistnra-se por ultimo bem e leva-se ao almofariz para acabar de triturar e reunir.

Empregam-se cinco grammas d'este pó por litro de agua cont mel, mas antes esterilisa-se o mel, juntando-lhe uma pouca d'agua, para que não queime, e levando-o ao fogo, onde se submette a uma temperatura de $90^{\circ}$ a $100^{\circ}$; a agua restante, que tem de se lhe addicionar, póde ser tepida ou mesmo fria.

Para se obter fermentaçoes completas e rapidas não se deve ultrapassar as proporẹves de duzentas a trezentas grammes de mel por litro de solução.

Duzentas grammas dão $8,85^{\circ}$ alcoolicos e trezentas $13,27^{\circ}$.

Quando a agua com mel estirer fria semeiam-se-lhe as leraduras, quer de mosto de vinho, quer as seleccionadas, que já se encontram facilmente á venda no nercado, principalmente em França e Allemanha.

Ch. Derosne, o intelligente anctor da curiosa colmeia album, prepara o hydromel da seguinte fórma:

Tira dos favos das abelhas duzentas granmas de pollen, fresco e puro, que desfaz em duzentas grammas de agua morna. Eun vasilha á parte dissolve trezcntas grammas de mel em trezentas grammas de agua, juntando-llie duas grammas de acido tartrico para a inversão do assucar, e leva ao fogo, onde ferve durante um quarto de hora, tirando a espuna á medida que apparece. Retirado do fogo este mosto esterilisado, e com todo o assucar fermentiscivel, reune-the seiscentas grammas de agua, e, $\log$ o que estiver frio, addiciona-lhe a levadura do pollen.

Este mosto guarda-se em vasitha tapada com um panno de linho, vasilha que se deve conservar á temperatura regular de $28^{\circ}$ a $30^{\circ}$. Para isto, no inverno, mergulha-se a vasilba em um recipiente com agua quente, agua que se muda de maulıã e á tarde; no verão basta conserval-a em sitio quente. $\Lambda$ fermentação começa no segundo dia, e ao setimo ou oitavo 
está o preparado em estado de servir para semear de dez a vinte litros de agua com mel.

Para cada liectolitro de hydromel ć preciso preparar, conforme as dóses e na fórma indicada, cinco litros de lcradura. A agua com mel a que o mosto é addicionado, precisa de tel sido anticipadamente acidulada pelo acido tartrico, na dóse do sessenta grammas por hectolitro, e depois esterilisada pela ebullição: é preciso tambem que esteja á temperatura de $25^{\circ}$ a $30^{\circ}$ centigrados quando lhe fòr reunido o mosto, afim de mais prompta e facilmente sc desenvolver a fermentação.

F́ conveniente não encher o casco onde se deitar o hydromel, pois o liquido augmenta com a fermentação, conserval-o sempre á tempcratura de $25^{\circ}$ a $30^{\circ}$ e mexel-o diariamentc com um pau, para fizer sahir o acido carbonico e permittir a entrada de bom ar puro.

T'crminada a fermentação trasfega-se c introduz-sc-llıe dez grammas de tanino dissolvido em meio litro de aguardente e dez grammas de sub-nitrato de bismutho por hectolitro, agitando bem o liquido.

Oito ou dez dias depois trasfega-se para o barril onde dere ficar.

O apicultor Péquart tem tambem um methodo sen de fabricar o hydromel, methodo a que deu o nome, e quc consiste cul preparar um mosto composto de rinte kilos de mel, duzentas grammas de bitartrato de potassa, duzcntas grammas de acido tartrico, duas grammas de tanino c cem kilos de agua. Faz ferver o todo, para matar os germens maus que o liquido possa conter, e, depois de fervido, deita-o $\mathrm{cm}$ uma rasilla bem lavada e tapada por meio de um obturador proprio, que deixa sahir os gazes desenrolridos dentro da vasilha mas nãi cntrar o ar, afim de não contaminar o liquido com as bacterias que scmpre conduz e, quando a temperaturat do lyviromel rlesce a $20^{\circ}$ centigrados, junta-lie um litro le levadura pura, deixa passar uns trinta dias, trasfega para nova rasillia onde soffre nma scgunda fermentação, aclarando depois, o que tem logar no fim de tres ou quatro mezes. 
Depois do largo emprego no fabrico do hydromel, o mel é utilisado, valiosa e proveitosamente, para melhorar os mostos provenientes de uras mal maduras e pobres en alcool, ou nos vinhos de segunda lagarada. Aos vinlos assin modificados dão em França o nome de Oenomel.

A quantidade de mel a reunir aos mostos varía com a quantidade de assuear que possucm. Para o verificar é preeiso fazer-se uso do glucometro Guyot que indica a graduação Baumé, a quantidade de assucar existente no mosto e a quantidade de alcool que se ha-de produzir após a fermentação do referido mosto.

Supponlamos, por exemplo, que o glucometro Guyot, merguthado em um mosto, indica a divisão 9,0 que mostra na tabella propria que o vinho devé vir a ter approximadamente $6^{\circ}$ de aleool. Querento elevar essa graduação alcoolica a $10^{\circ}$ deita-se em uma rasilha dez litros de mosto, mergulha-se n'elle - glucomctro e vae-sc-lhe dissolvendo mel até 0 instrumento fluctuar entre as dirisões 15 e 16 que correspondem a $10^{\circ}$ de alcool. Conhecida a quantidade precisa para dez litros, facil é saber-se a que ó indispensavel a toda a lagarada.

Gcralmente emprega-sc nos mostos fracos rinte e einco grammas te mel por litro ou dez lilos por hectolitro.

o mel dissolve-se em ağla quente, que se reune assim ao mosto, logo que a fermentação tumultuosa principiar. O mel nâo só dá alcool ao vinho, mas tambem lim bello sabor especial, que muito lhe angmenta a qualidade.

Para o rinho da segunda lagarada procede-sc da seguinte fólllia:

Tirarlo o rinho da primeira pisa, na quantidade, por cxemplo, de dez liectolitros, junta-se immediatamentc ao bagaço identica quantidade de agua com mel, quente, c preparada na proporção de rinte kilos de mel por hectolitro de agua. Deitada a agua com mel no bagaço dá-se uma rapila pisa, e deixa-se fermentar o todo, fazendo, por meio de grades de madeira, quc se collocam sobre o lagar, que o bagaço subsista sempre debaixo do liquido, para evitar a fermentação acetiea. 
Em seguida opera-se como com o vinho commum.

0 . Tinagre de mel obtem-se dissolvento o mel em agrua na proporção de cem a duzentas grammas de mel por litro de agua, eonforme se quizer o rinagre mais ou menos fórte, e, depois da fermentação alcooliea ter terminarlo, o que leva semanas, e mesmo alguns mezes, como aeonteee com o liydromcl, fazcr-llie soffrer a fermentação aectiea. Quando um hydromel salie ordinario o melhor, tambem, é transformal-o em vinagre, que fica sempre magnifieo, de primeira ordem.

Se se tem uma rasilha já arinagrada, uma mãe rinagre, deita-se n'clla a agua eom mel, depois de fermentada, ou o hydromel, e colloea-se ao sol, eom o batoque abcrto.

$\mathrm{Na}$ falta da mãe vinagre, deita-se em uma vasillaa qualquer e junta-se-llic borras de rinagre, on fermento de pão de milho, c pue-se ao sol, ou junto rlo fogo, até fiear eompletamente azerlo. Depois de bem arinagrado trasfega-se para uma nora rasilha e aromatisa-se com estragão, pimenta, eraro da Inclia, ou gengibre, que se suspende na rasilha dentro de um pequeno saceo.

No easo do vinagre ficar muito branco póde-se-lhe dar còr com amóras bem maduras, que se the juntam em quantidade proporcional á intensirtade do eolorido desejado.

Para preparar a rguardente de mel distilla-se o liydromel, as aguas de lavagens, ou mesmo o mel dissolvido $\mathrm{cm}$ agua. Cada litro de mel, que pesa, termo médio, mil e quatrocentas grammas, dá un litro de boa aguardente.

Segundo Froissard um kilo c duzentas grammas de mel granulado dão um litro de aguardente a $50^{\circ}$.

Para fazer desappareeer da aguardente o clıciro caraeteristico do mel, deita-se no alambiquc, afim de absorrer os oleos essenciacs do liquido a distillar, um pouco de hortelĩ-pimenta, de zimbro, de carvão ou mesmo um litro de créme de leite por eada cem litros do liquido.

Eum França envelhecem a aguardente extralida do mel juntundo-llıe, por litro, um centilitro de infusão de easea verde de $110 \%$, um centigramma de essencia de amendoas amargas, 
dez centigrammas de cachou em. pó e uma gotta de alcali volatil.

Alguns negociantes addicionam-lhe tambem uma duzia de grammas de calda de assucar por litro de aguardente, o que a torna mais macia e the dá o aspecto xaŕopento da aguardente rellia.

Com o mel tambem se póde fazer cerveja. Na Belgica utilisam-o muito para tal fin com o mellor resultado.

Eis como o snr. Arthur Devos, apicultor de Houdeng, ensina a preparar a cerreja de mel:

"Para se obter cento e sessenta litros de boa cerveja de mel, depois de se tor bem lavado $\mathrm{nm}$ harril de cento e sessenta litros, e se ter disposto na adcga, prompto a receber o liquido, fervem-se noventa litros de agua com duzentas e cincoenta grammas de lupulo durante meia hora a tros quartos d'hora, en uma qualquer caldeira; após a fcrvura passa-se esta agna por uma peneira, afim de ser extrahido complctamente o lupulo. Emquanto esta agna estiver quente dissolvem-se treze kilos do mel; depois deixa-se arrefecer.

Á parte levam-se outros noventa litros de agua á temperatura de ebulliçĩo, e, logo que isto se der, deita-sc-lhe duzentas e cincoenta grammas de lupulo, mexe-se e passa-se logo pela peneira.

Quando as aguas estivercm já um pouco frias, entre $22^{\circ}$ a $18^{\circ}$ dcita-se a agua com mel no barril e acaba-se de cncher com a segunda agua, que só esteve em rapido contacto com o lupulo, havendo, porém, o cuidado de se deixar o liquido a dous on tres centimetros abaixo do batoquie.

Dissolvem-se então quarenta centilitros de boa levadura de cerveja usual, bem fresca, em um litro de liquido tirado do barril, deitase a levadura assim preparada na rasilla, e agita-se-lhe fórtemente 0 conteúdo com um pau.

Inclina-se um ponco o casco, de lado, afim do liquido chegar ao nivel do batoque e colloca-se uma cella sob o barril, para recolher os productos da fermentação, que póde durar approximadamente de seis a oito dias.

Quando a fermentação está em plena actividade, quer dizer quando o liquido corre para fóra do barril, é preciso harer o cuidado de encher o barril de manlã e á tarde com agua lupulisada, da que crescen, por isso que se fizeram cento e oitenta litros ao todo, em vez dos cento e sessenta que leva o barril.

Terminada a fermentação, o que se conhece quando o liquido não 
extravasa, nem se desenvolve acido carbonico, endireita-se o barril e tapa-se com o batoque, mas $11 \mathrm{~m}$ ponco ao de leve.

Passado uma ou duas semanas póde-se clarificar a cerveja com gelatina e, depois rle bem clara, engarrafal-a.»

Com o mel ó facil confeccionar soberbos refrescos para o verão. Eis a receita de tres dos mais apreciados em França.

IVel aromatico. Em rinte e cinco litros de agua deitam-se eineo kilos de mel e tres claras d'oro. Faz-se ferver o todo durante uma hora e depois junta-se-lle canella, gengibre, cabeças de craro, noz muscada e rosmaninho. Deixa-se arrefecer, còa-se atravez um panno e serre-se.

Limonada garosa. Quando se quizer beber uma boa limunada gazosa para auxiliar a digestão, deita-se en meio copo d'agua, uma colher de mel, algumas gottas de summo de limão e uma pitala de bicarbonato de sóda. Dissolve-se bem tudo, e, logo que o estirer, junta-se-lhe meia pitada de acido tartrico em pó, que produz immediatamente uma fórte fermentação.

Champagne de mel. N'um recipiente aberto deita-se em dez litros cle agua a ferver um kilo cle mel, um poueo de levadura de cerreja, e o aroma que se pretender. Mistura-se bem e, dous dias depois, quando a fermentação está em plena aetivilade, engarrafa-se en garrafas fórtes. O acido earbonieo que se desenvolve dentro da garrafa, torna depois o liquido muito espumoso, semelhando ehampagne.

O Tarope de mel obtell-se deitando em um tacho proprio para o fabrico de doces, quatrocentas grammas l'agua, dous kilos de mel e quarenta grammas de greda. Deixa-se ferver durante dez minutos e, em seguida, junta-se-lhe una clara d'oro e eineoenta grammas de negro animal (earvão d'ossos).

Logo que levantar fervura tira-se do lume e deixia-se arrefecer durante um quarto d'hora, lepois do que se passa o xarope, ainda morno, por $11 \mathrm{~m}$ panno, repetidas vezes, até ficar claro; em estando limpo engarrufa-se.

Para que este xarope so couserve é preciso que fique a $31^{\circ}$ Baumé. 
A todos os licores de fructos, flôrés aromaticas ou de essencias pódc juntar-se proveitosamente, em vez de calda de assucar, mel, ou melhor, o xarope de mel, cuja' receita já indicanıs. Envelhecem assim mais de prompto e ficam mais perfunados e agradareis ao paladar.

Em especial preparam-se exclusivamente com mel os seguintes licores:

O Chrysomel que é um precioso licor, que se obtem dissolvendo quatro litros de mel em agua ató formar oito litros da mistura. Levam-se ao lume e deixam-se ferver até ficarem reduzidos a metade; addiciona-se-lhe, por ultinı, tres litros de alcool aromatisarlo com a cssencia ou fructo que sc preferir e engarrafa-se.

Licor de amcixas. Cozem-se rinte e cinco ou trinta ancixas em quatro litros de bom vinlıo branco sccco. Depois da primeira ferrura junta-se-lhe um kilo de mel, un litro de aguardente e dez grammas de canella; dá-se-lhe mais duas ou tres fervuras, retira-se a rasilha do lume, cobre-se com um panno e deixa-se cstar de infusão durante cinco dias, depois do que se filtra e chgarrafa.

Licor de cerejas. Deita-se em um litro de aguardente um kilo de cerejas pretas, bem maduras, ou ginjas e deixa-se macerar durante vinte dias. Passado este tempo tiram-se as cerejas, filtra-se o alcool e addiciona-se-lhc um kilo de mel.

Licor de morangos. Esmagam-se dous kilos de morangos n'uma peneila, e deita-se-lhc por cima, no estado de ebullição, um xarope feito com dous kilos de mel dissolvido en tres litros d'agua. Faz-se passar tudo atrarez a peneira, deixa-se arrefecel por completo, e, logo que o estiver, junta-se-lhe dous litros de aguardente de $18^{\circ}$ a $20^{\circ}$, filtra-se e engarrafa-sc.

Licor dos namorados. Em um litro de aguardente macera-se, durante um dia, cen grammas de flôr de laranjcira, filtra-se e mistura-se com trezentas grammas de mel dissolvido em $u m$ quartilho de agua.

Licor de ribes. Juntam-se em um frasco quinhentas graulmas de fructos de ribes-pretos, muito maduros, uma gramma 
de cravo, uma gramma de canella, litro e meio de aguardente e quinhentas grammas de mel.

Deixa-se estar de infusão durante quinze dias, mexendo cuirladosamente o liquido duas rezes por dia e, depois, côa-se atravez un panno de linho bem tapado, espremendo para que todo o liquido passe, e engrarafa-se. Este licor é muito estomacal e digestivo.

Krambambmi de mel. Este preparado allenĩo obtem-se misturando de\% litros de alcool a $90^{\circ}$, duas grammas de essencia de casca de noz muscala, duas grammas de essencia de cardanomo, dez grammas de essencia de cravo, tres gottas de essencia de pimenta, seis gottas de essencia de rosa, quatro kilos de mel, meio litro de xarope concentrado de cerejas pretas, para lhe dar còr, e, agua precisa para levar o licor a $45^{\circ}$.

Chartrase de mel. Dissolrem-se oitocentas grammas de mel em meio litro de agua e misturam-se com um litro de aguardente, duas gottas le essencia de rosa, duas gottas de essencia de canella e dez gottas de essencia de absintho; deixa-se estar dous dias de infusĩo e depois filtra-se.

Curaçco. Durante quinze dias macera-se, em um litro de aguardente, cincoenta grammas de cascas de laranjas, sem 0 branco, uma pitada de canella, um putco de casca de noz. muscada, duas cabeças de cravo e depois reune-se-llue seiscentas grammas de mel dissolvidas em seiscentas grammas de agua, filtra-se e conserva-se em garrafas.

Tangerinada. Em um litro le aguardente põe-se de maceraçĩo, uns oito ou nove dias, as cascas de seis tangerinas cortadas aos bocadus, mistura-se depois esta aguardente com du\%entas e cincoenta grammas de mel liquido, filtra-se e guarda-se.

Créme d'Augelica. Pezam-se duzentas e cincoenta grammas de hastes de Angelica, cortudas de fresco e sem follhas, cortam-se aos bocados e deitam-se de infusĩo, durante dous mezes, em tres litros de aguardente, juntamente com um kilo de mel, meio litro de agua, doze grammas de noz muscada, quatro granmas de canclla e seis cabeças de craro. Findo o tempo de infusão filtra-se c engarrafa-se. 
Créme d'anir. Deitam-se eineoenta grammas de semente de aniz em dous litros de boa aguardente. Após oito dias de infusão, eôa-se atravez um panno de linho bem tapado e juntase-lhe $1 \mathrm{~m}$ kilo de mel dissolvido en meio litro d'agua. Deixa-se repousar durante dous dias, depois to que é eonveniente filtrar antes de guardar em garrafas.

Ratafia de Angelica. Este lieor é um magnifico exeitante, estomachieo e sudorifieo. Fabriea-se do seguinte modo: Hastes verdes de Angeliea quarenta e eineo grammas, aguardente mil duzentas e eineoenta grammas, agua setecentas o cineoenta grammas, mel mil grammas. Deitam-se as hastes de Angelica em um fraseo grande eom a aguardente, e, depois de oito dias de maeeração, junta-se-the o mel o a agua. Mistura-se o todo bem, e, passados oito dias, filtra-se e engarrafa-se.

Ratafia de cerejas. A $1 \mathrm{~m}$ kilo de eerejas pretas, ben maduras, extralıe-se-llıe os pés e os caroços, e põe-so de infusão, durante um mez, em tres litros de aguardente. Esmagam-se metade dos earoços tirados e deixam-se, tambem durante o mesmo espaço de tempo, de infusão em um litro de aguardente. Por ultimo filtran-se os dous liquidos e reunem-so juntamente eom um kilo de mel.

Ratafia de craro. En um quarto de litro de agua filtrada, põe-se de infusão, durante rinte e quatro horas, vinte e cineo grammas de eabeças de eravo da India e vinte e cineo grammas de eanella; decorridas as vinte e quatro loras passa-se a infusão atravez $\mathrm{nm}$ panno e addiciona-se-lle tres litros de vinlio fino e $\mathrm{um}$ kilo de mel, e leva-se a ferrer juntamente eom o eravo e a eanella, que ficaram de infusão, mettidos dentro de um saquinho de panno. Depois de ferver levemente mistura-se eom meio litro ou $\mathrm{nm}$ litro de boa aguardente, engarrafa-so e lacra-se muito bem. Quanto mais velho melhor é este lieor.

Ratafia de cuminhos. Este ratafia é verdadeiramente precioso eontra as indigestões. Confeceiona-se maeerando, durante quatro dias, trinta grammas de semente de euminho em um litro de agnardente e depois addieionando-lhe mejo kilo de mel e filtrando. 
Ratafia de framboczas. Em um frasco grande deita-se um kilo de framboezas, bem maduras e sem pes, e quatro litros de aguardente fórte, arrollia-se e expõe-se no sol durante dous mezes. Findo este tempo reune-se-llie um kilo de mel, eôa-se e guarda-se em garrafas.

Tiatafia de groselhas. Reunem-se bem quinhentas grammas de suceo de groselhas, quinhentas grammas de mel e meio litro de aguandente, filtram-se e engarrafam-sc.

Ratufia de Loresa. Em dous litros e meio de aleool a $20^{\circ}$ põe-se de maeeração, durante vinte dias, quarenta grammas de açafrão, oitenta grammas de açofeifa, sessenta grammas de tamaras, sessenta grammas de passas d'ura, tres grammas de eoentro e tres grammas de canella. Terninada a maceração eòa-se, reune-se no liquido mil e trezentas grammas de mel dissolvido em seiscentas grammas de agua e filtra-se.

Ratafia de marmelos. Cozem-se os marmelos, depois de tirada a casca e as pevides extrahe-se-lhe o sueco, a eada tres kilos do qual se ardieiona mil e trezentas grammas de mel, mil e quinhentas grammas de alcool a $35^{\circ}$, quinze grammas de amendoas amargas esmagadas, doze grammas de canella, oito grammas de coentro, quatro grammas de easca de noz museada e uma gramma de eraro da India. Deixa-se maeerar uns vinte dias e depois filtra-se.

Ratrific de aimbro. Põe-se de infusão durante oito dias em um litro de aguardente, trinta grammas de baga de zimbro e eineo grammas de easca de eanella. Findos os oito dias remem-se-lhe duzentas e cincoenta grammas de mel, filtra-se e guarda-se.

Lacope dé cachou. Este xarope, muito adstringente, é um magnifico tonico para o estomago. Manipula-se dissolvendo uma onça de extracto de eachou em meio litro de agua, juntandolhe $u m$ kilo de assuear, e levando em seguida a ferrer ao lume.

Punch de mel. Ferve-se uma garrafa de bom vinho braneo e, quando estiver em ebullição, addieiona-se-lhe trezentas grammas de mel e um limão cortado aos boeados.

Serve-se emquanto quente. 


\section{O mel como alimento - Iguarias e doces fabricados com mel}

Com a descoberta do assucar de canna, foi progressivamente diminuindo, em todo o mundo, o consumo do mel, a deliciosa e salutar substancia doce extrahida gotta a gotta de milhares de flòres pelo canceiroso cuidado das laboriosas abelhas. Nós os portuguezes, seguindo a corrente geral, fomos tambem substituindo as velluas iguarias e doces temperados com mel, que, dle geração em geração tinhamos recebido dos romanos, e muito principalmente dos arabes, por guisados francezes que são o tormento do estomago e a ruina da saude.

Felizmente não se extinguiu ainda por completo o uso do mel em Portugal; nas aldeias, onde a tradição se conserva mais firme e duradoura, onde as modernismos custam a penetrar, o mel continua a ser utilisado na confecção de variadissimos pratos que são a delicia dos rudes filhos do campo nos seus dias de festa.

Procuramos reunir, o mais que nos foi possivel, as receitas das iguarias e doces preparados no nosso paiz com mel, no que fomos dedicadamente auxiliados pelo nosso bom amigo e erudito continuador do Portugal antigo e moderno, dr. Pedro Augusto Ferreira, abbade aposentado de Miragaya, e pelos ex. mos snrs. padre José Bernardo de Moraes Calado, prior de Miranda do Douro; padre José Raphael Rodrigues, abbade de Soutello do Valle; padre José Augusto Tarares, abbade de Ligares; padre 
Joaquim José da Rocha Espanca, prior de S. Bartholomeu de Villa Viçosa; padre Manoel Joaquim Soares de Figueiredo, abbarle de Arouca; dr. Luiz de Figueiredo; conservador em Ponte da Barea; Antonio de Barros Costa, proprietario em Taboaço; padre José lzidro Brenha, da Poroa de Varzim; Faustino Sarmento, do Gerez; padre José Manoel Cordeiro, arcypreste de Alfandega da Fé; commendador Delfim José de Oliveira, de Penella e J. Nunes, do Alemtejo, a quem, aqui, tributamos o nosso profundo reconhecimento pelos valiosos subsidios foruccidos.

Para não alterarmos o largo valor das informações recebidas transcrevemol-as tal qual nos foram enviadas:

"Na noite de Natal, depois do tradicional bacalbau, são muito usadas, em Arouca, tortas de trigo desfeitas em agua temperada com adubo, en que deitam, tanto n'una cousa como na outra, uns assucar, outros mel. Nos logarejos distantes da rilla é nel, por o terem de casa; na villa é mel e assucar.»

(Arouca - P. Wermol Joaquim Soares de Figueiredo, Ablade do Arulaca.)

"Na povoação de Guillado, freguezia de Tilla Pouca de Aguiar, no dia de Natal, comc-se cabra ensopada com mel e feijão branco. Em Téllòs, concellio de Villa Punca rle Aguiar, azeitouas com mel, e rabanalas de trigu com mel. Em TresJlinas, fregruezia do mesmo concello de Villa Pouca d'Aguiar, bòlo rle pão centeio, quente, ao sahir do förno, molharlo com mel, e de mata-bicho, pela manlan, aguardente com mel. Na Lixa do Alvĩo, aldeia da freguezia de Soutello do Valle, concelho rle Villa Punca de Aguiar, e povoaçũes risinlıs, arroz cozido con mel substituindo o arroz doce de assucar e canella. No Bragarlo e porvaçoes visinhas, chouriço e bueho de porco cheio de trigo e mel, posto a funo e cozido pelo anno adiante. E un prato farorito d'esta gente.

Em Codeçoso, freguezia do concellıo de IIonte-Alegree, e terra do muito mel, ó prato forçalo o mel rellı, partido ás fatias como marmelada. Em Soutello do Valle, concello de 
Villa Pouca de Aguiar, usa-se caldo de mel para as mulheres de parto.»

(Soutello do Valle $-P$. Jose Raphael Rodrigues, Abbade de Soutello do Vallo.)

"Sopa peitoral. Ferre-se bem, em bastante agua, duas mâos de vacca até ficarem completamente cozidas, côa-se o liquido por um panno raro, addiciona-se-lhe meio arratel de passas, sete colheres de mel, um pouco de funcho (herva doce) e deixa-se ferver ató que fique reduzido a dous quartilhos; então junta-se-lhe um quartilho de leite, tres oros batidos, dá-se outra ferrura e serve-se.»

(Extremadura.)

* Sarralulho doce. Depois do sangue de porco estar bem cozido, espreme-se e separa-se aos pedaços, deitando-o $\mathrm{cm}$ um tacho com um pouco de pingue, algumas amendoas cortadas aos bocados e mel confórme o desejado grau de doçura. Mexe-se cuidadosamente e serve-se o mais quente possivcl.»,

(Penafiel, l'aredes e norte do pai\%)

"Nos dous concelhos lemitrophes Miranda e Mogadouro, não se usam lambarices de mel senão nos seguintes casos: na consoada do Natal applica-se ordinariamente o mel nas fritas de massa, mas isto não póde dizer-se que seja uma usança antiga, geralmente seguida.

Usam isto muitas familias do poro, porque não pódem ou não querem comprar assucar para preparar a calda para essas fritas, o que n'outras casas de certa ordem se prefere. As familias do poro tambem fizem essas fritas por occasião do entrudo, applicando o mel ou o assucar conforme teem uma cousa ou outra.

Quando ordinaria e geralmente se usa mais o mel, ó por occasião da matança dos porcos. Passados dous dias, ou no dia immediato ao da matança, trata-se de derreter o unto do porco ou porcos, convidando-se usualmente para essa festança os amigos, visinhos e conpadres. É então (e é quasi sempre para a noite que reservam essa patuscada), que comem os torresmos em grandes pratos ou barranhões cheios de mel. Os torresmos, 
a que se chamam rijoes, são os pedaços de unto derretidos na panella, e que já deixam menos apurados ou derretidos, para melhor se poderem comer.

Estes rijões são sempre servidos no fim, como prato de honra, depois dos petiseos de lombo e outras iguarias.

Além. d'isto o mel usa-se para comer pcras assadas ou cozidas, ás quaes, partidas no prato, se thes deita mel em rez de assucar.

Tambem entre o poro, em vez de assucar, se usa bastante o mel em umas fatias de pão, chamadas torradas de mel e que consistem em pão primeiramente cozido e depois frito em azeite, sendo antes molhadas ou passadas por ovo batido, e por ultimo amollecidas en mel ao lume. Este petisco não é mau de todo.»

(Miranda do Douro - P. José Bermerdo de Moraes Calado, l'rior de Miranta do Douro.)

"No sul aprecia-se muito assar as batatas no fôrno, tirarthe a pelle, abril-as ao meio emquanto quentes, e enchel-as de mel. Ficam assim com um sabol e aroma especial. É comer e nuorrer por mais. »

(Aleintejo-J. Nuns.)

"Com a agua da lavagem dos favos já espremidos e das rasilhas que serviram para os conter, faz-se n'estas localidades um ingrediente chamado agua mellada, que a gente pobre costuma utilisar para as bolas, fritas, torradas, etc. Com o mel fazcm lambarices, taes como filhós, millio, arroz doce, etc. »

(Ligares-T. José Augusto Tavares, Abhale de Ligitres.)

"Nas freguezias da serra da Peneda e da Amarella, temperam ainda hoje as bebidas com mel, como o faziam outr'ora, antes da descoberta da America, e do assucar estar tão rulgarisado. Além d'isso o mel, nas localidarles referidas, e comido sobre o pão de trigro nas occasiões de festas ou bòdas. »

(l'unte da Baren - Dr. Inix de Figuriredo.)

- Vinho quonte. Tempera-se em frio o rinho com assucar e algum mel, indo depois ao lume até ficar quente, mas sem 
ferver, porque então azéda. Usa-se na noite de Natal em todo o Minho.»

"Oros mexidos do Natal. Amollece-se o pão em bastante leite, juntando-lhe sufficiente assucar e algumas gemmas d'ovos com umas poucas de pedras de sal; estando bem amollecido o pão põe-se ao lume em un tacho, com bastante mantciga e mel; em fervendo junta-se-lhe o pão amollecido, continuando a mexer-se sempre até enxugar e ficar louro. São optimos estes oros mexidos muito usados no Alto Minlıo.»

(Ponte da Barca - O mesmo.)

"Outra rariedade de mexidos. Parte-se o pão aos bocadinhos e deita-se em uma taça, cobrindo-o com leite (que se póde destemperar com agua); junta-se-llie ovos, sendo metade inteiros e outra metade só as gemmas, e mais o assucar preciso para adoçar. Tudo isto fica amollecendo o pão durante algumas horas antes de ir ao lume.

Em um tacho deita-se mel com bastante manteiga, e, logo que levantar ferrura, junta-se-lhe o pão amollecido, mexe-se senpre até aloirar, servindo-se entĩo este bello prato, que de preferencia se usa na vespera do Natal, dia de Annu novo e vespera do dia de Reis.»

(Ponte da Barca - 0 mosmo.)

"Formigos. Os fornigos, a que tambem dão o nome de mexidos, preparam-se em Paredes, e visinlanças, da seguinte maneira:

Tempera-se com o preciso sal uma certa quantidade de agua a ferver, e, por cada litro de agua, deita-se approximadamente um quarteirão de vinho fino branco, nma ou duas colheres das de sopa cheias de manteiga e o mel preciso para adoçar. Parte-se pão aos bocadinhos e bota-sc dentro até que chupe o liquido todo, ficando completamente abeberado. Tem-se seis gemmas d'oros bem batidas, deitam-se sohre o pão, mexe-se bem, e leva-se an lume para cozer os ovos e o pão, depois do que se deita em travessas, servindo-se quente ou melhor em frio, no dia seguinte.»

(Paredes.) 
"Formigos. Outra reccita. Reunem-se um litro de mel e uma canarla de agua, e fervem-se até ficar em ponto, addieionando-lhe então dous ou tres pães trigos coltados aos boeados e mexendo até absorrerem a calda.»

(Taboaçn o Pescrueira - Antonio de Barros Costa.)

"Millo com mel. En rarias localidades do norte do paiz, costumam, quando o milho ainda não está completamente maduro, assal-o e depois comel-o misturado com mel.»

(Vianna do Castollo.)

* Antes da introduç̧ão do assucar de canna era geralmente usado o mel para adoçar todas as confeções; linje, por estes sitios, o seu uso, entre as elasses abastadas, está restricto á agua mel, torrão brancon, bôlo pôdre, bòlos saloios, mồas e nógados.

Os pobres fizem ainda com mel outras lambarices, como as arorins, e temperam com elle as papas de farimha de trign, que thes serve de eeia. Tanto os pobres como os rieos adogam eom elle o rerpucijuo.»

(Villa Visosa-P. Jonguim Josë da Rocha Espanea, I'rier de S. Bartholonen de Villa Tięusa.)

" Ayur mel. Esta resulta das lavagens la cêra dos faros já espremidos; vae ao lume em tacho e ferve até se pòr em ponto. Tende-se barata pelas ruas a cem e cento e vinte reis D litro. Alguns negociantes, quando o mel não tem procura, reduzento a agua mel, para the darem extraccĩo.»

(Villa Viçosa - O mosmo.)

"Tomrio branco. O torrão braneo, de origem hespanhola e fabricado por liespanloes, é uma lambarice muito popular; indispensavel nas feiras do Alemtejo. Rapazes das villas e cidades, mulheres do povo e camponezas, dĩo o eavaquninho por este duce, e quem nâo púde comprar dous vintens ou um rintem d'elle, consola-se em adquirir uma lasea de dez reis.

Ha em Villa Viçosa uma andaluza, que eliega a render 
na feira de maio d'esta rilla, e na de S. João, d'Evora, cincoenta arrobas (setecentos e cincoenta kilogr.) de torrão branco. O seu preço actual é de quatrocentos reis o kilogrr.; sómente por'ém o fabricam por occasião das feiras.

Prepara-sc assim: Ao mel, depositado em caldeiras grandes, en quantidade não inferior a uma arroba, junta-se grande porção de claras d'oros. Posta a caldeira ao lume, ć remexida por dous homens de pulso rijo, com espátulas ou pás de ferro, por espaço de vinte e quatro horas, revesando-se os dous, por não poder aguentar um só aquella faina.

Depois de extrahida. esta massa para caixotes forrados com papeis (ordinariamente de jornaes), é coberta com amendoa doce, descascada e torrada ou com pinhões e assucar pilé. Toma logo uma tal consistencia que fica parecendo una grande pedra anrarella; e, para se partir nas feiras sobre uma mesa de madeira, e ser rendido a retalho, ć necessario empregar pesadas cutcllas d'aço.»

(Villa Vicosa -0 mesmo.)

«Bôlo pǜlie. 0 bôlo pôdre, ou torta, ainda hoje se faz, segundo as medidas autigas, nas porções de um quarlilho, meia canada e canada, que é a quantidade de mel empregarlo. Junta-se-lhe pouco menos da mesma porção de azcite, umas seis ou oito gemmas doros por cada quartillo e pequena quantidade de canella e gergelim. Depois reune-se-llue farinha de trigo, quanto baste.

É primciro bem batido tudo isto e desfeito n'um alguidar, de que usam as confeiteiras; deita-sc depois n'um tacho de metal amarello, de tamanlıo proprio para a quantidade; leva-se a $\ln$ fồno de cozer pão, onde se lhe nĩo toca señão quando se julga estar já cozido, o que se verifica mediante uma palha de centcio, cravando-a no bôlo até ao fundo. Se não estiver bem cozido torna ao fòrno. Quando se quer levar á mesa, tallıa-se o bôlo aos pedaços com uma faca.»

(Villa Viçosa -- O mesmo.)

«Bôlos saloios. Fazem-se como o bôlo pôdre, salva a differença de se distribuir a massa em fôrmas de lata, recor- 
tadas, mais largas para eima do que para baixo, afim de poderem ser d'ellas extralidos depois de cozidos no fômo. Essas fồmas, pequenas, são postas em taboleiros de follıa de Flandres, e assim se mettem no fôrno.»

(Villa Viçosa - 0 mesmo.)

* Brôcıs. Das brôas usan prineipalmente os pobres por seren mais baratas. A um quartillo de mel junta-se pouco menos de outro de azeite e um ponco de canella. Bate-se isto eom a mão, n'um algnidar, reunindo-lhe farinlıa de trigo (ou milho) até ficar a massa em orden e manipulam-se bolinhos redondos e compridos, sobre os quaes se dão golpes de faca em esquarlia, ou em iier, on fazem eirculos eon derlaes, para eompostura; vão ao fôrno em taboleiros de lata e depois de cozidos são polvilhados com assucar. Estas bròas são as ordinarias.

Clamam-se esculdadas, quando, depois de tendidas na mão, são levarlas a $u$ m tacho de agua a ferver, por meio de uma escumadeira de metal amarello, e tiradas depois d'este esealdamento para o taboleiro do fômo.

Chamam-se fervidas quando a dissolıção e preparaçào da massa é feita ao lume n'um tacho.

As duas ultimas são as mais tenras. »

(Villa Virosa - 0 mesmo.)

«Nógados. Sómente estes fritos, usadlos no entrudlo, não dispensan o mel, porque, constando elles de pequenas tiras de massa, preparada com ovos em fórma de pinlaão, não pódem apegar-se uns ans ontros sobre uma taboa de tender pão, sen que se empregue o mel en ponto de pasta. Este gruda-os ou agrupa-os u'um grande bòlo, que depois se tallha com una faca, aos pedaços. »

(Villa Vip̧osa - U mesmo.)

* Vógudo. Oatra receila. Ein un litro de mel, deita-se dous litros de amendoas limpas da casca e partidas em bocadinlıos, meio litro de nozes tambem eortadas aos bocados e meio litro de pinlı̃es. Misturi-se tudo muito bem, e, depois, pũe-se ao lume mexendo sempre. Em o mel estando bastante 
grosso, retira-se do lume e estende-se a massa sobre uma taboa, onde se deixa ficar até seccar por completo.»

(Portimaัo.)

«Nas gulodices do Natal, tanto em Guimarães como no Gerez, o mel só entra nos mexirlos on formigos. Em Guimalães alguem o emprega tambem nas rabanadas, moda esta que parece ter sido importada de Amarante. »

(Gerez-Faustino Sarmento.)

«Pinhouda. No Alemtejo, nomeadamente em Alcacer do Sal, ó artigo de muita renda a pinhocula, doce fabricado con mel e pinhôes inteiros. Prepara-se como o nógado.

O nosso amigo e distincto philologo dr. José Leite de Vasconcellos, em $\mathrm{nm}$ artigo publicado a pag. 66 do $3 .^{\circ}$ fasciculo do Archoologo Portuguer (1894) diz, referindo-se ao commercio da pinhoada en Alcacor do Sal, «nas lojas de negocio, ás portas, está á venda, em caixinhas losanguicas, a pimhoada, doce composto do mel com pinhões inteiros. Este uso era novo para nim.» (Pova do Tarzim-P. José Izidoro Brenha.)

"Rabanadas com mel. São fatias de pão trigo enbebidas em agua, ou mais geralmente en vinho, passadas por oro, depois fritas, e empilladas nas travessas com camadas de assucar e mel para fazer môllıo.»

(Povoa do Varzin-o mesmo.)

"Rijōes. Usa-se em algumas casas, mandarem para a mesa, rijōes e um prato com mel, no qual molhan os rijões. Dizem ser muito bom. »

(Povoa de Tarzim - 0 mesmo.)

"Migas doces. Trinho aquecido com manteiga, on pingue onde não ha manteiga, e mel; só onde de todo em todo não ha mel é que o substituem por assucar. N'este viuho deitam sopas de trigo e até de pão de milho.

É a unica especialidade da Poroa.»

(Puvoa de Varzim - 0 mesmo.)

"Em Ribeira da Pena, terra de muito mel, emprega-se 
cste nas fillıós, nos bôlos de arroz, de chila, de abobora, e nas rabanadas, e nos pasteis de bacalhau, de carne, etc.. e ha ató quem o deite na sôpa. Em muitos logares d'exte concellio lá-se como merenda aos trabalhadores.»

(Riboira da Pona-I. Alearo Augusto de Carvalho Pimenla.)

"Bólos de arros. Deita-se em 1 m alguirlar um litro de agua, um kilo de farinha de trigo, e umas areias de sal; depois de bem misturado junta-se-lhe oito oros com clara e gemma, e rluzentas e vinte e cinco grammas de arroz, cozido só em agna temperada com sal. Bate-se tudo, fritando-se em seguida cm azeite ou manteiga, formando bòlos.

Á parte, em um tacho, deita-se um litro de agua e meio litro de mel: deixa-se ferver tudo, passam-se pelo liquido os bòlos, dispõem-se em uma travessa, e polvilham-se com canella, derramando-lhe por cima a calda que crescer.»

(Tuboaģo e Pesquoira - Intonio de Burros Costa.)

"Somhos de manjar-branco. Faz-se um créme fórte, de farinla de arroz, oros e leite, e deita-se n'elle o peito de uma gallinha ou perdiz, o mais picado possivel; tempera-se de sal, assucar e amendoa ralada. É preciso que tudo, junto e bem misturado, fique em uma massa, que se córta em pedaços do tamanbo de uma noz, e se fritam em azeite ou manteiga, e se dispõem, polvilhados de canella, em uma travessa, cobrindo-os com uma calda fabricada de metade e metade mel e agua, bem fervidos juntos. »

(Taboaŗo e l'esqueira - 0 mesmo.)

"Orellus de abbade. Amassa-se muito bem meio kilo de farinha, sessentas grammas de manteiga, oito oros, um pouco de fermento c o sal preciso. Deixa-se levedar durante duas horas e, depois, com um rôlo de madeira, estendc-se a massa, que não deve estar muito dura, até ficar bastante delgada, c córta-se da fóma que se quizer; frigem-sc os pedaços em um tacho em azeite a ferver, dando-lhes então com um garfo o feitio de uma orelha, e, depois de fritos, passam-se por mel e polvilham-se com canella.»

(Taboayo e l'osqueira-O nosmo.) 
"Filhores. Algumas pessoas dizem vélhores. Fazem-se no concellıo de Penella, por occasião do Natal, do modo seguinte: Toma-se a abobora menina, que é cortada em pedaços e descascada, lançada n'nm tacho com agua e depois de bem cozida passada para um alguidar, onde é reduzida a massa; a esta massa junta-se farinha espoada de trigo e uma pequena porção de fermento, amassa-se até ficar um pouco consistente e deixa-se levedar; depois vae-se tirando a massa ás collıeradas e deitando-se separadamente em uma frigideira que deve conter azeite bem quente; fritas as fillozes são depositadas em um alguidar, e por cima d'ellas deita-se o mel necessario para fical'en bem ensopadas.

E, principalmente, nos annos de safra de azeitona que estas filhozes apparecem em grande quantidade. Por antigo uso e costume, os proprietarios de olivaes, são quasi obrigados a dar as filhozes a varejadores e apanhadeiras. Retinem as vozes d'estas, repetiudo rarias vezes a velha cantiga:

Lá rem o senhor noss'amo

Com seu collete d'ilhozes,

Gorgulho the dê no trigo

Se não nos dér as filhozes.

A distribuição das filhozes realisa-se no ultimo dia de serviço e na occasião do jantar; logo em seguida ha dança descante e foguetorio.»

(Commendador Delfim Josi de Oliveira, auctor das Memorias de Penella.)

"Merendeiras. Bem cozida a abobora menina, e depois de escorrida a agua rae para o alguidar onde é reduzida a massa; junta-se-lhe uma porção de farinha, metade de trigo e metade de milho, meio quartilho de azeite, um quartilho de mel e uma pitada de erva dóce; amassa-se tudo até ficar a massa um pouco dura, e depois de levedada, estendem-se as merendeiras, em fórma ovada e un tanto aguçadus nas extremidades, collocam-se em bacias, polvilhan-se os bôlos com farinha de trigo e vão ao fòrno.

Fazem-se no concelho de Penella e são destinadas, prin- 
cipalmente, para brindar as ereanças na oceasião da festa do Natal.

(0) mosmo.)

"Bôlo pödre. Dous litros de mel e ums de azeite, duas colheres de canella e doze cabeças de eravinho em pó, uma pequena porção de erva doce bem pizada e rinte e quatro oros; deita-se tudo isto em $\mathrm{mm}$ alguidar, onde é bem batido eom eollier de pau, e ao mesmo tempo se llue vae misturando farinha de trigo até a massa formar costcllo; untam-se as bacias eom manteiga de raeca, lança-se n'ellas a massa e, depois de polvilhadas eom farinlıa de trigo, as bacias rão ao fôrno. Para se conheeer se o bòlo está eozido, espeta-se n'elle um palito e, em sahindo enxuto, póde letirar-se do fôr'no. Corta-se en pedaços, polvilla-se eom assuear fino, guardam-se em um vaso de folha, e no fim de dez a quinze dias estará o bòlo pôdre.

(O mesmo.)

* Clarificação do mel. Deitem-se tres litros de agua e seis kilogrammas de mel n'uma rasilha da capacidarle de treze litros; derreta-se o mel ao fogo; junte-se um kilogramma on mais de branco de Hespanla ben pulverisado, e as cascas de dous limões pequenos; misture-se turlo com a espumadeira; junte-se a essa mistura quinhentas grammas de earvão de elarifiear, sem deixar de mexer; batam-se bem tres ovos, e deitem-se em tres litros de agıla. Quando o mel eomeçar a agitar-se, regue-se com uma pouca d'essa agua, passe-se em seguida pelo coador de panno, torne a deitar-se n'aquelle, e continue a passar-se ató que fique (le uma limpidez perfeita.»

$$
\text { (Iisbon-P. Planticr - o Cosinheiro dos Cosinheiros.) }
$$

"Pudim de mel. Batem-se juntos, em um tacho, quatorze oros eour elara e gemmia, e quinhentas grammas de mel. Pôe-se ao fogo e, quando a pasta estiver um pouco eonsistente, reune-se-lhe quinhentas grammas de farinla de arro\% e eento e vinte e cinco grammas de manteiga. Deita-se em uma fòma ehata, bem untada com manteiga e enfariuhada, deixa-se cozer, tiris-sc da fôrma e serve-se em frio.»

(Algarve.) 
"Bôlos de milho e mol. Amassa-se em um alguidar quiulentas grammas de fariuha de milho, quinhentas grammas de farinha de trigo, quinhentas grammas de manteiga, quinhentas granmas de mel, algum cidrão e amendoas cortadas aos bocalos. Em estando a massa bem consistente, córta-se em bôlos, que se passan por gemna d'ovo, e se levam ao fômo a cozer.

(Algarve.)

« Bòlo do céo. Ferve-se juntamente cento e vinte grammas de amendoa ralada, quinhentas grammas de mel, uma colher de sopa de manteiga c outra de farinha de trigo. Deixa-se arrefecer e, depois, addiciona-se-the dez gemmas d'oro, duas claras, uma casca de limão (só o amarello) bem ralada; bate-se tudo, deita-se em uma fôrma bem untada com manteiga, e vae ao fôrno a cozer.

(Algarve.)

"Brôas de mel. Põe-se a ferver ao lume, em um tacho, litro e meio de azeite e cento e vinte e cinco grammas de herva doce bem pisada. Tem-se em um algnidar nove litros de fariulıa de milho, sobre a qual se deita o azeite a ferrer, niexendo até ficar em massa. Cobrc-se o alguidar com um cobertor durante um quarto de hora, após o que se reune á massa cinco litros de farinha triga, o sal preciso, kilo e meio de mel, cem grammas de canella em pó, quinhentas grammas de cidrão c trezentas grammas de anıendoa. Mistura-se bem tudo, e depois leva-se a cozer ao fòmo em fôrmas grandes. »

(Algarve.)

"Pão de especies (Pain d'épice). Não ć precisamente uma industria moderna o importante fabrico d'este pão. Os gregos, que o conheciam, chamavam-lhe métilate. Mais tarde temperaram-o com especies e o pão de mel tomou então o nome de pão de espccies. Ao presente ć fabricado mechanicamente, empregando-se para isso farinla de centeio ou de trigo, e mel da Bretanha ou do Chili.

O mel chega em barris de quatrocentos kilos da Bretanha ou oitenta a com kilos do Chili. É armazenado em adegas 
cimentadas com regneiras e poços, para recolher o mel rertido pelos cascos durante os calores. As farinhas são amassadas mechanicamente, em recipientes contendo cento e cincoenta kilos, deitando-se-llıe a mesmo tempo o mel aquecido em estufa e passado pela peneira. O trigo e o mel puro dão pão de especie do genero Dijou; o centeio e o mel puro o genero Iaris.

Alguns fabricantes deitam metade mel e metade melaço, manipulando uma massa que dá um pão duro, proprio para a gente dialdeia, e quo se vende nas feiras e festas dos arredores de Paris. A amassadura leva meia hora, depois do que se colloca em uma estufa, onde a massa fica durante vinte e quatro horas, em recipientes de lata, collocalos ao ar livre, por cima de caldeiras de fundo duplo, aquecidas a vapor. Em seguida a pasta é disposta em quadros de madeira, podendo conter quatrocentos lilos, e, finalmente, adégald, quer dizer, abaudonada durante seis semanas em una adega fresca. A pasta fica assim lomogenea e endurece a ponto le ser difficil quebral-a. Depois d'este repouso bem merecido, tritura-se a pasta, até ficar reduzila a farinlaa, que se mistura com um pouco de mel. Então retoma o seu primeiro aspecto e está apta a ser enfeitala. Dá-se-lhe a fóma quadrada, a de parallelipipede (precé), assin chamalo por isso que foi pela primeira rez rendido com este nome no tempo de Henrique IIT, na feira das Barricadas, on de fóma redonda, conhecida pelo nome de nomuclle, visto que foram as freiras (womnes) de Remiremont que a imaginaram.

Condensam-se as pastas com clara d'oro e guarnecem-sc com fiuctos seccos, amendoas, etc.; dispõon-se nos taboleirns de lata, e procede-se finalnente á coç̧̃̃o em grandes fòrnos especiaes, que muitas rezes funccionam noite e dia, o que prova 0 grande numero de amadores do relho pão dos Gregos. Este pão não necessita de fermento algum, pois o mel desempenlaa o papel de fermento, fazendo inchar a pasta.

São rerdadeiras fabricas os estabelecimentos que preparam em França o pão do especies. Possuem ammazens especiaes 
para o trigo, para o mel, para os fructos de doce, vindos em caixas de Clermont-Ferrand, para o assucar, para os ovos, etc.

Uma pequena machina cólta os fiructos das dimensões requerirlas.

As amendoas, pistaches, cidrão, angelicas, etc., são directamente expedidas dos respectiros paizes de producção.

O assucar é misturado com claras d'oros, em barricas espccines. As grandes fabricas teem sempre á sua disposição um leposito de mais de cincoenta mil oros, examinados á luz e conservados em tinas de cimento sob agna de cal. Cada tina, carada no sub-solo, contém approximadanente vinte mil oros, comprados geralmente em abril. São tirados do deposito um a um, e os operarios, collocados proximo de un bico de gaz, obserram-os antes de irem para a fabrica. Um só oro mau podia estragar todo o fabrico de um dia.»

(Paris.-Ilenri de Parille.)

"Püo de especies. O far cum melle dos romanos não ela mais que un pão de especies que os pobres offereciam aus deuses inmortaes; os egypcios e os gregos comiam-o á sobremesa.

Em França, sob a antiga monarchia, o pão de especies figurava em primeiro logar nos repastos, apreciando-o doidamente, dizem, Agnés de Sorel e Margarida de Nararra. M. ${ }^{\text {me }}$ de Sòrigné fazia expressamente viagens a Reims, para comer nomnettes á rainla. No seculo pássado, as donas de casa fabricaram este producto cada una a seu modo; o monopolio d'elle, existia, porćm, nas mãos dos padciros. Só no começo do seculo é que o seu fabrico se tornou una profissão, fazendo então as casas mais afamadas, como as de Dijon, pães de especies representando figuras mais ou menos grotescas. O impulso, porém, estava dado, e em breve as cidades de Reims, Dijon, Chartres, e mais tarde Paris, Beaurais, Orleans, Rouen e Blois tircram as suas fabricas especiaes do saboroso pão.

A invenção da nomette pertence á commmnidade de Remiremont (Vosges); as religiosas d'este estabelecimento fazian 
- pão de especies sob a fórma de pequenos pães redondos para seu uso; Dijon apoderou-se do modelo, dando-lhe o nome. Hoje as nomnettes fabricam-se em toda a França.

O parallelipipede (Puvé) de Chartres tem uma origem historica.

Henrique III, em recordação do sympathico acollimento que recebeu dos habitantes d'aquella cidarle, quando deixou Paris para evitar as perseguiçòs dos secturios da Liga, que erginam barricalas n'aquella epocha (1588), fundou a feira de maio, que tomou, por esse motivo, o nome de feira das barricadas.

Foi n'esta fcira que, pela primeira vez, appareceram pães de especies sob a fórma do famoso parallelipipede (paré) que se tornon legrendario, e que é muito apreciado pelos amadores.

Fabríca-se duas qualidades de pães de especies, que só. differem na farinha; $u m$ o feito com farinha de trigo, outro com farinha de centeio. Ha uma outra qualidade manipulada com farinha de areia, que é muito mais leve, mas mais ordinaria que as outras. Todos estes productos preparani-se com partes iguaes de farinha e mel de primeira qualidade.

A pasta assim feita conserva-se muito tempo; addicionase-lhe, no momento da cocção, trinta grammas de potassa por cada ciuco kilos de massa e aromatisa-se de differentes fórnuas. Eis todo o scgredo.»

(Fransa - Jowouhoy.)

"I'úo d'cspecies. Outra receita. Depois de se ter cozido - mel a unı fogo fórte, atć espumar, deita-se, a ferver, em uma cavidade fcita no mcio da farinha que estiver na masseira, e, conı uma colher de pau, mistura-se o mel com a farinha, até que fique reduzido a mma pasta consistente a que a farinha vão adhira mais.

Estende-se entĩo a pasta na masseira, e, depois de a ter deixado arrefecer durante um quarto dhora, reune-se-lhe uma infusão de potassa bem branca, preparada da vespera, por exeniplo quinze grammas de potassa para cada quinhentas gramuas de mel, e amassa-se esta mistura conıo o pão usual. 
Quando a pasta estiver prompta dá-se-llıe a fórma que se pretender, cozendo-a em um fómo de calor moderado. Á sahirla do fôrno, esfrega-se a superficie do pão, com um poueo de colla de peixe derretida en cerveja; cobre-se-lhe tambem então a purte superior eom amendoas, nozes, pinhõcs aos bocados, e fragmentos de todos os fructos, seccos ou crystallisados.

Para se obter um pão de especies de primeira ordem, basta reduzir em pó dez grammas de aniz, tres grammas de coentro, outro tanto de cravo e canclla, e incorporal-os na pasta, com perlaços de amendoa, cidrão, e cascas de laranja e limão de doee.»

(Paris - Sophie Wallel.)

"Pão de especies. Outra receita. O fabrico do pão de especies, reclama conhecimentos que só póden ser adquiridos pela pratica. As dóses a empregar devem variar segundo as circunistancias. Deve-se preferir o mel do outomno, mas serve perfeitamente o mel de colza, sanfeno, de tilia, etc. Póde-se empregar diversos fermentos, porém prefiro a todos a potassa da America.

Amontoa-se a potassa em um vaso de faiança vidrada e não em vaso de vidro, por eansa de ser transparente. Deitase-lhe por cima uma pequena quantidade de leite com uma pouca d'agua quente, para humedecer a potassa e faeilitar-lhe a dissolução. Se, depois de vinte e quatro horas, a potassa, que deve fiear em pasta sólida e não liquida, contiver grãos resistentes á lamina de uma faca, 6 de má qualidade e não deve ser utilisada. É preciso que fique macia eomo a manteiga.

Este fermento, eonservado em sitio escuro, dura indefinidamente.

Derrete-se o mel a um fogo muito modcrado, e, quando tiver attingido de $60^{\circ}$ a $S 0^{\circ}$ deita-se no local onde deve ser amassado. Convém não utilisar nem alguidares, nem masseiras, nem utensilios que tenham estado $\mathrm{cm}$ contacto com a massa de pão, por causa do fermento de que poderiam conservar vestigios. Mistura-se então ao mel farinha de trigo 
como se fosse para fabricar o pão. Faz-se lluna pasta bastante consistente, que se deixa cvaporar durante alguns dias, em um, logar fresco e arejado, antes de ser empregada. Póde-se fazer differentes qualidades de massa de pão de especies, segundo as variedades de especies empregadas, e não ats utilisar señ̃o á medida que fòr preciso, por isso que a pasta se conserva durante muito tempo.

Para fazer pão de especies fino toma-se esta pasta, mistura-se-lhe dez grammas de potassa por kilo e amassa-se com nm pouco de mel frio. A quantidade d'este mel póde rariar do tamanho de uma noz á de unn oro, para dons ou tres kilos de massa. Depois de bem amassada á mão, dá-se fórma á pasta por meio do rolo e de farinha, e coze-se em fôrno quente, se os bôlos são pequenos e delgildos, e em fòmo brando se são espessos. O calor proprio para o pão, póde ser tomado por base, augmentando-o ou diminuiudo-o segundo o tamanho dos bôlos.

Se se cmpregar muito mel o pão de especies incha no fồno e rolta-se; se tirel farinha em demasia, é pesado, compacto, tumescendo com difficuldade. É bom, antes de fazer os bôlos, metter no fồno um pequeno pedaço de pasta para liıe ajuntar, no caso de ser preciso, mel ou farinha.

Ans pães de especies de luxo, addicionam-se-lhe perfumes, marmelos rerdes, coentro, canella, casca de noz muscada, craro, gengibre e rapaduras de casca de limão e laranjas, pulrerisados.

Para os biscoutos deita-se mais, arellãs, nozes, amendoas cortadas ans perlaces e as especiarias que se quizer, quanto mais se the deitar melhor ficant dá-se-lhe a espessitra de $11 \mathrm{~m}$ dedo e cozem-se em latas untadas com manteiga on còra. É preciso separal estes biscoutos antes de arrefecerem e conserral-os em logar seceo e quente.

Não se deve rleixal cuzer muito o pão de especies, por isso que, sendo cozido demais, fica com $11 \mathrm{~m}$ sabor amargo detestarel. Se, pousando-lhe o dedo levemente por cima, elle resistir, estí cozido; se o declo se enterrar, ficando marcado 
por uma pequena cavidade, não está ainda bastante cozido. - Os bôlos de mel não teem necessidade de levedar como o pão, podendo portanto esperar que o fòrno cstcja convenientemente quente, e serem cozidos logo que a manipulação estiver terminada. »

(1'Apiculteur - S. Sigand.)

"Pão de especies hollander. Duzentas e cincoenta granımas de mel, trezentas e setenta e cinco grammas de fariuha, sessenta grammas de mantciga, uns ovo, cinco grammas de no\% muscada e cinco grammas de sóda. Mistura-se a secco com a mão e faz-se uma pasta consistente, que se dispõe da fórma que se quizcr e se coze no fôrno.»

(Denuler.)

* Bôlo ingler de mel. Addiciona-se a un kilo de mel duzentas e cincoenta grammas de manteiga fresca derretida, o succo de dous limões, e uma pitada de noz muscada; mexc-se tudo bem, junta-se-lhe um kilo de farinha de trigo e anassa-se.

Faz-se com a massa uma folha de um centimetro de espessura, córta-se aos bocados e coze-se levemente com manteiga.»

(O meswo.)

"Bôlo de fructos e mel. Um kilo d'uvas passas (de $\mathrm{C}_{0}$ rintho ou Damasco), quatro oros, cinco pequenas chavenas de farinha, duas charenas (charcnas de café on cluá) de mel, uma chavena de manteiga, uma chavena de leite, duas colhcres (das de café) de cremor tartaro, uma colher de sóda, uma colher de cabeças de cravo em pó, uma colher de canclla c uma pitada de noz muscada. O todo bem amassado e corido a fogo brando.

(0 mesino.)

"Bôlo francer de mel. Em meio litro de leite dissolvem-se cento e cincoenta grammas de assucar branco; quando o assucar estiver derretido junta-se-lhe trezentas e cincoenta grammas de mel, faz-se ferver o todo, escuma-sc um pouco, retira-se cm seguida do fogo e deixa-se esfriar; mistura-se então quinhentas grammas de farinha e duas grammas de potassa, e faz-se uma pasta, que se põe a cozer durante uma 
Lora en uma torteira, ou em um fồno, ou mesmo em uma formalla. No fôrno é preciso menos tempo para a cocção.»

(Abbé J. B. Joinnot, curé de Villers sous Prény - Franco.)

"Bôlo de flôr de lararijcira. Coze-se um kilo de mel em um. litro d'agua e depois escuma-se; quando o xarope começa a tornar-se mais espesso ajunta-se-llie trezentas grammas de flôres de laranjeira e mexe-se; depois de dez minutos de ebullição deita-se uma colher de claras d'oro batidas com assuear ell pó, mexe-se ainda até ficar consistente, deita-se em pequenas fômas, ou simplesnente sobre papel azeitado com bom a\%cite fino ou manteiga, e lera-se ao fôrno, depois do que se polvilha com assuear.»

(0 mesmo.)

"Bolo esponja $110 \mathrm{mel}$. Toma-se uma grande chavena de mel, mma grande charena de farinha e cinco oros. Junta-se as gemmas d'estes oros ao mel, e batem-se as claras em neve. Misturatso o todo, mexendo o menos possivel. Dá-se ao bòlo um sabor especial, addicionando-lhe um pouco de succo de limão.»

(O mesmo.)

* Fillós ou somhos de freira. Deita-se em uma eassaróla um quarto de litro de agua, alguns grãos de sal, tres colheres de sopa de mel relho, outras tantas de manteiga e uma casca de limão, rapada. Quando turlo estiver quasi a ferver, retira-se (lo fogo ardliciona-se-lhe bastante farinha para fazer uma nuassa, mexe-se fórtemente com uma colher de madeira afim de que nĩo pógue á cassaróla e fique miforme. No fim de alguns minntos deve estar prompta, sem adherir aos dedos; deixa-se então arrefecer um momento.

Quebra-se um oro e mexe-se ainda muito para o incorporar á massa, depois ontro ovo, o assim successiramente ató que ella fique manearel e escorra muito lentamente da eollier quando a levantarmos acima da cassaróla.

Em ultimo logar deita-se mais uma elara de oro batida em neve; ao todo tres ou quatro oros e uma clara. Se não 
hourer pressa, deixa-se repousar a massa uma ou duas horas, tir'a-se depois, eom uma eolher, pedaços de massa do tamanho de uma noz, que se fazem eahir em azeite on mateiga a ferver toeando-lhe eom o dedo.

Esta massa eresee muito ma frigideira se o azeite ou manteiga hão estiver demasiado quente ao principiar. Serrem-se quentes, bem dourados, polvilhados eon assuear; tambem não são maus frios. Póde-se, para tornar melhores as filhós, addieionar-se-the agua de flò de laranjeira hatida eom o primeiro ovo.»

(0 mesmo.)

«Biscoutos de mel. Uma charena de mel fresco, meia eharena de nata quente, dous oros, meia eharena de manteiga, duas eharenas de farinla de trigo, meia eolher, das de eafé, de sóda e meia colher de eremor tartaro. Amassa-se, córta-se da fórma desejada e eoze-se lentamente 110 fôrno.»

(0 mesmo.)

"Roussettes de mel. Faz-se uma nuassa eom um litro de farinha, tres ovos, eento e vinte e cineo granmas de mel, outro tanto de manteiga fresea, uma pequena pitada de sal, nata, unı enther grande de kirsch on mirabella e um poueo de agua de flôr de laranjeira; deixa-se repousar durante tres loras, e, depois, eólta-se em figuras, alinda-se a parte superior, se assim se desejar, frita-se e, por ultimo, polrilham-se os dous lados eom assuear. Este doee é excellente tanto quente eomo frio, e dura uma semana.

(O mosmo.)

"Croqueltes de mel. Cozem-se quatro decilitros de mel eon doze cabeças de eraro pisadas, e un poueo de eanella; junta-se-lhe uma elavena das de eafó, de aguardente de mirabellas ou ontras quaesquel ameixas, e mexe-se bem ao deitar o espirito. Emquanto o todo estiver ainda quente addicionase-the oito decilitros de farinha de aveia, e faz-se ma pasta espessa, que se estende em seguida, se eórta nos feitios desejados, que são cozidos em tórteira, tirando-os antes de arrefecer. »

(O mesmo.) 
« Pasteis de mel. Meio sestario de boa nata fresca, $11 \mathrm{~m}$ quarto de kilo de farinha de aveia, tres colheres de sopa de agna de flôr de laranjeira. Bate-se a nata com a farinha, e, quando a mistura estiver completa, reune-se-lhe o mel, a agua de flòr de laranjeira, e bastante nata para que a massa fique muito clara; fazem-se pasteis como de ordinario e só se retiram do fôrno quando tiverem uma linda côr.»

(0 mesmo.)

"Marmelada de peras, maçus, ameixus, ete., ete. É preciso, principalmente em casa dos apicultores, que o mel seja empregado em todos os preparados em quc póde substituir o assucar, e elle deve-o rantajosamente fazer sob o ponto de vista hygrienico, na preparação das marmeladas. Para as marmeladas de maçã, peras, etc., escolhem-se de preferencia fructos bem maduros, que se cortam aos pedaços, depois de the terem sido cuidadosamente tiradas as cascas, sementes, e todas as partes pôdres ou duras, e branqueam-se, cozendo-os em agua, para lhe fazer desapparecer o sabor acido; em seguida cozen-se em xarope de mel clarificado, de fórma que não fique um só pedaço de fructo sem ser penetrado pelo xarope.

Dere haver o cuidado de mexer a massa de tempos a tempos, sobretudo no fim da cocção, para que a marmelada não pegue ao fundo do tacho, e conservar o lume sempre moderado. Dere ferrer de tres a cinco lioras.

Conhece-se que a cocção é boa tirando uma colher grande da marmclada e deixando-a arrefecer; se, arrefecendo, ficar, pouco mais ou menos, em espessura e consistencia semelhante ao melaço, está cozida.

Póde turnar-se esta marmelada, que deve primeiro ficar muito bem cozida, mais delicada, arldicionandu-lhe, no momento da cocção, um pouco de baunilha cortala nos bocados. Dere-se tamben filtrar o xarope para o obter mais claro, e conservar o toro em um logar secco. Retirada do fogo deita-se em rasos de vidro ou louça vidrada.

A proporção a empregar regula em cinco kilos de mel por cada dez kilos de fructo.

(O mesmo.) 
* Moedas de mel. Lança-se em uma ganella, ou vaso côvo, duzentas e cincoenta grammas de fariuha; quebram-se em cima, ao meio, dous ovos, aos quaes se mistura ponco a pouco farintra, mexendo com uma colher. Deita-se em um prato côro, cento e vinte e cinco grammas de manteiga e cento e vinte e cinco grammas de mel, que se liquifazem na fornalha de um fogão, durante tres ou quatro minutos. Retira-se do fogo e bate-se bem, como para uma mayomnaise, a farinha onde se quebraram os ovos.

Em a massa estando bem homogenea, junta-se-lhe uma colher de agua de flôr de laranjeira ou uma colher, das de café, de alcoolato de baunilha, segundo o gosto de cada um.

Pega-se•em um funil, ou na sua falta em uma colher de sopa, e deita-se sobre uma placa de lata, bem untada com manteiga, pedaços de pasta de fórma redonda e do tamanho de moedas de duzentos reis, tendo o cuidado de as espaçar tres ou quatro centimetros en todos os sentidos. Mette-se a placa na fornalha, e faz-se um fogo moderado. Dez minutos. depois as moedas, que ficam louras, teem crescido até quasi tocarem umas nas outras; retiram-se para as collocar na parte superior do fogĩo, e metter na fornalha uma outra lata preparada duḷante a coç̧ão da primeira.

Tiram-se então as moedas cozidas fazendo-as saltar com uma faca. É preciso haver o cuidado de, quando salie do fôrno, não pousar a lata com as moedas em cima de uma mesa, visto que não seria depois possirel extrahir uma só intacta, pois quebrariam todas ao desprendel-as.

Logo que a lata estiver vazia, deixa-se arrefecer antes de llıe collocarem novos doces. Para a operação dar bom resultado dere possuir-se tres latas das dimensões da fornalla do fogão da casa. As pequenas muedas, depois de arrefecerem sobre unıa peneira ou un jornal, são conservadas em latas.

Uma dona de casa cuidadosa, póde manipular e cozer um kilo d'estas moedas en duas horas. Para este kilo tem de se empregar duzentas e cincoenta grammas de manteiga, quatro- 
centas grammas de mel, quinhentas grammas de farinha e quatro ovos.»

(O mosmo.)

«Qucijo branco com mel. Para se obter uma das mais deliciosas sobremesas, adoça-se com mel liquido, extrahido de fresco, queijo branco créme, rega-se com um pouco de kirsch e amassa-se.»

(O mesinn.)

* Bôlos de Milĩo. Mistura-se duzentas e cincoenta grammas de mel, tres ou quatro ovos, meio kilo de farinha e uma casca de limão; bate-se bem tudo, e, logo que a massa estiver prompta, estende-se sobre uma mesa em camadas não muito delgadas e córta-se de feitios diversos, em estrellas, corações, corôas, etc., que se dispõem a pequena distancia uns dos outros, sobre uma lata untada com manteiga, douram-se com gemma d'oro batida com mel, e cozent-se a fogo brando.»

(Do Apiculteur Suisse.)

"Bôlo de mel á americana. Com oito a dez dias de antecedencia prepara-se a seguinte massa: Mel escuro scte kilos e quinluentas granmas, ovos quinze grammas, fermento em pó oito grammas, ammoniaco liquido dez grammas, amendoas cortadas aos bocados um kilo, limão $1 \mathrm{~m}$ kilo, canclla vinte grammas, cabeças de cravo dez grammas, noz muscada de\% grammas, farinha nove lilos.

Aquece-se o mel e espuma-se deixando-o ferver um pouco; logo que arrefecer reune-se-lhe o resto. Córta-se, coze-se e gela-se, ainda quente, com assucar e clara d'ovo.» (1. Muth.)

"Filhós de marẽ̃. Tira-se a casca a boas maçãs reinettes, cortam-se ás talhadas e mergulham-se duas ou tres horas em aguardente de fructos, depois em mel liquido e por ultimo passam-se por farinha, fritam-se em manteiga, polvilham-se de assucar e servem-se.

Fazem-se da mesma fórma filhózes de pecego, damasco, pera, etc. »

(Mademoisclle Chimence Weyland.)

"Castamhas de mel. Preparam-se da seguinte fórma: Põe-se mel a ferver em banho maria, e deita-se-lhe dentro 
castanhas descascadas e bem limpas. Logo que as castanhas estiverem cozidas, tiram-se e põem-se em taboleiros a seccar ao sol.»

(O mesmo.)

"Leckerlis de Bâle. Quinhentas grammas de niel, duzentas e cincoenta grammas de assucar en pó, cento e vinte grammas de casca de limão de doce, cortada em bocadinhos (on casca de laranja de doce), trezentas e setenta e cinco grammas de amendoas, igualmente cortadas aos bocades. Espccies: trinta grammas de canella enı pó, duas graumas de cravo en pó, uma gramma de noz muscada em pó; o amarello da casca de um limão, rapado, ou vinte gottas de esscncia de limão, uma ou duas colheres de kirsch, e approximadamente meio kilo de farinha. Toma-se metade da farinha e faz-se uma abertura ao centro, na qual se mettem as especiarias. Aquece-se o mel com assucar e deita-se, quasi a ferver, sobre as especies no meio da farinha.

Mistura-se com uma colher de pau, depois amassa-se ajuntando, pouco a ponco, amendoas cortadas aos bocados, casca de limão, kirsck e o resto da farinha. Quando a pasta estiver homogenea e sufficientemente consistente, addiciona-selhic oito a dez grammas de carbonato de ammoniaco, e outro tanto de carbonato de potassa pulvcrisados na occasião do emprego.

A massa-se de novo para que estes saes fiquem bem repartidos na massa, e, depois, com um rolo, lera-se esta a uma espessura de tres a quatro millimetros, que se dispõe em latas cobertas com uma fórte canada de farinha e coze-se em $\mathrm{um}$ fòmo em calor mediano. Loğo que sahir do fòrno divide-sc o bôlo, riscando-o com uma faca, sem atraressar a massa, gela-se com assucar frio, cozido on perlado, deixa-se arrefecer sobrc as placas, scparam-se os pedaços e conservam-sc em sitio secco.»

(Do Apiculture Eclcctique.)

"Tortas de peras. Coze-se em um quarto de litro de vinho fino doze peras, bem descascadas, mas inteiras e com os 
pćs, e, logo que eederem á pressão do dedo, tiram-se do lume c põem-se a eseorrer em uma peneira.

No molho que fiea na cassaróla deitan-se quinhentas grammas de mel e leva-se o torlo á eonsistencia de xarope, escumando sempre que fôr preciso. Durante a cocçâo far-se, com um oro e cento e vinte e cinco grammas de mantciga, uma massa folhada; estende-se com o rolo, e dispũe-se $\mathrm{cm}$ uma torteira de tamanho mediano. Enche-se a torta cun papel e eobre-se este eom uma pasta muito delgada, para obter uma especie de bandeja de massa.

Coze-sc a fogo brando, e, logo que a massa estiver bem consistente e loura, tira-se da fòrma, extrahe-se-lhe a cobertura de papel, e, no logar vasio, polvilha-se de assucar.

O mel, durante este tempo, transformou-se cm um xarope expesso, onde se mergulham uma a uma as peras, que se dispõem sobre a massa, com os pés para o ar. Se ficar poueo xarope augmenta-se com uma eolher de rhum; se creseer muito, reduz-se, e deita-se sobre a torta.

Serve-se a frio.»

(Do Bulletin d'stesnes.)

"Fruclos de doce a frio. Colhem-se uvas bem maduras, ou outros bons fructos tacs eomo cerejas, damascos, ameixas, grosellas, ete., tiram-se-lhe os pés, e deitanl-se em frascos, que se enehem de mel frio até que os fruetos fiquem eompletamentc cobertos. Arrolham-se hermetieamente os fraseos e conservam-se em um logar fresco. Os fruetos assin preparados duram mezes. »

(Dennler.)

"Fructos de doce a quente. Deitam-se tres kilos e quinhentas grammas de uras, ou outros quaesquer fruetos, en um vaso de boeal largo, tendo o euidado de os não esmagar. Faz-se em seguida um xarope de dous kilos de mel e meio litro de bom vinagre, ao qual se addieiona uma pitada de eabeças de eraro e eanella; aquece-se durante vintc minutos, espuma-se, deita-se quente sobre os fructos e, em seguicla, tapa-se hermetieamente o raso. Os fruetos conserrados d'esta fórma duram aunos.» 


\section{0 mel como remedio}

O mel foi largamente empregado na antiguidade, occupando logar proeminente quer no uso interno, quer no uso exterło. Era com o auxilio do mel que a medicina d'outr'ora debellara as mais perigosas doenças, e era devido ao uso constante de mel que os nossos antepassados attingiam, saudareis e fórtes, a mais longa relhice.

O devotado propagandista do uso do mel o abbade Vuirnot, escreve o seguinte relativamente á applicação therapeutica do delicado producto das abelhas:

«Devem todos lembrar-se: $10^{\circ}$ Que o mel é extrahido de variadissimas plantas das quaes conserva as suas propriedades beneficas especiacs; ora quem póde orgullhar-se de conhecer todas as virtules das plantas? 2. Que o mel, derido á sua composição, não tem necessidade de elaboração especial no estomago, actuando directamente sobre os orgãos internos, como o assevera 0 dr. Dubini. A botanica (as plantas) e a physiologia (o homem) não poderão conhecer toda a efficacia do mel senão quando a botanica e a physiologia já não tiverem scgredos.

0 uso do mel exerce uma influencia benefica sobre os orgãos interiores, a bòca, a garganta e o apparelho digestivo.

$A$ bôca. As aphtas da bôca das creanças cedem ao emprego do mel com pcdra hume ou borax. Na dentição das creanças fricciona-se as gengivas com um clecocto de althea, on linhaça, ou com tintura de açafrão misturado com mel. 
A garganta. Fazem-se exccllentes gargarejos com agua de salva fervida, uma colher de mel e uma colher de vinagre por chavena.

Orgâos resuriatorios. Os professores, os inusicos e todos os que usam e abusam da roz e cla palavra, deviam fazer uso fiequente do mcl. Em virtude do acilo formico que o mel contém é efficaz contra a rouqfidão, a tosse, catarho, grippe, bronchite, e, como derivativo, contra a angina o catartho pulmonar, a asma, etc. O uso regular do mel com tanchagem tem curado mais de um doente do peito.

O mel colhido nos pinheiros é o melhor de todos para as doenças d'este genero. Una poção agradavel e util para o mesmo fin, é um bôlo de vinho quente, de cidıa ou lcite, dulcificalo com mel e um pequeno copo de kirsch. Nais de uma pessoa teria prazer em tomar este remcdio sem estar doente.

Apparelho digestivo. 0 mel, em virtude das suas propriedades refrigerantes, levemente laxativas e purgativas, é muito bou contra as inflammações do estomago e mesmo da bexiga.

Nĩo ha, diz o dontor Guérin, medicamento mais faroravel contra as febres risceracs, medicanento que devia ser o alimento privilegiado dos temperamentos febris. Misturado com alho mata os vermes intestinaes.

Entre nós ó ainda hoje usado em muitos remedios caseiros, contra a colica, constipaçōes, dùres de cabeça, rheumatismo, tumores, inflammações de pulmōes, hemorrhagias, febres biliosas, queimadellas, etc.

A medicina reterinaria tambem se utilisa larga e proveitosamente do mel.

Eis as suas principaes applicações internas, quer em Portugal, quer no estrangeiro:

Chlorose. Segundo Jaccoud e frequente, no Hanover e na Dinamarca, o curar-se a chlorose por meio do mel. As doentes são enviadas para a aldeia, onde, juntamente com os bons ares do campo, são sujeitas a uma alimentação em que predomina o mel. Segundo Tselıman o effeito curativo do mel na chlorose, é devido á doença ser motivada por uma insufficiencia de assucar hepatico.

Doencas de gargunta. Gargarejos de agua e mel, e duas collieres, das de clá, de mel, todas as manliãs. Se a affecção augmentar, desenvolvendo-se inflammação, prepara-se una pasta com partes iguaes de farinha, gemma de oro, manteiga sem 
sal e mel, que se deita em un panno fino e se põe á rolta do pescoço, atando-a com um lenço.

Havendo tosse violenta emprega-se o oxymel, que se prepara cozendo, até á consistencia de xarope, duas partes de mel e uma parte de bom vinagre branco.

$\mathrm{Na}$ Boliemia tratam a diphteria com mel, tomado internamente ás collıeres, de dez en dez minutos, e friç̧ões externas com elle, no pescoço.

Hamet aconsella, para fazer desapparecer'a tosse mais rebelde, ingerir aó deitar na cama, um copo de vinho fino com mel, ou um grog com muito nel.

Aphtas. Curam-se untando-as repetidas vezes ao dia com mel, ou com o mel rosado, que se prepara pondo de infusão, durante rinte e quatro horas, um kilo de petalas seccas de rosa, em seis litros d'agua.

Filtra-se e depois evapora-se em banho maria, até ficar reduzido á terça parte, e addiciona-se-lhe então quantidade identica de mel.

Ás creanças de peito curan-se-lhe as aphıtas, e mesmo as constipações, deitando em um quadro de panno fino de linho, mel amassado com um pouco de miolo de trigo, atando e dando-lhe a sugar esta especie de mamadeira.

Doenças de bexiga. o Apiculteur pratique diz que o vinho branco, com mel, e o chá de abelhas (sessenta abelhas en duzentas grammas de agua a ferver) constituem um bello remedio para a retenção de ourinas e doenças inflammatorias da bexiga.

Insomnias. Evitam-se, tomando ao deitar meia duzia de collieres das de sopa, de mel.

Hemorrhoides. É bom contra este incommodo tomar todos os dias, ao jantar, algumas colleres das de sopa, de mel.

Dyspepsia. 0 mel é muito ntil aos dyspepticos.

Ha numerosos casos de cura de dyspepsias, rebeldes a todos os tratamentos, por meio do uso quotidiano do inel.

o Gleanings in bee culture citando factos de cura por meio de mel, de dyspepsias rebeldes, que nenhum medicamento 
tinha podido alliviar, diz que o mel é o mais são dos manjares assucararlos. Que os melhores medicos inglezes c allemães o recommendam ás pessoas que não podem tonar assucar nem xaropes. Os professores Root e Cook proclamam-o conio um nectar quasi digerido, propriedade esta derido á passagem do mel pelo estomago das abelhas; o mel ć facilmente digerido pelas pessoas quc não podem tomar nenhum outro assucar.

Influchser. Cura-se prompta e radiealmente eom mel, ou mesmo com o hyrlromel velho, que é mma bebida superior à todos os respeitos.

Apcritico. Prepara-se $u m$ soberbo aperitivo e $1 \mathrm{~m}$ bom remedio a applicar nos embaraços gastricos, pondo de infusão, durante dez dias, trezentas grammas de cerefolio, duzentas e cincoenta grammas de centaureas em dous litros e meio de vinho branco. Após alguns dias de infusão, reunem-se-lhe sessenta e cinco grammas de mel e rinte e cinco grammas de agua fervida ou filtrada, deixa-se macerar durante dez dias, côa-se e guarda-se.

Resfriamentos. O sur. Desquartiers escrere o seguinte a tal respeito:

"Ha algums annos apanhei un grande resfriamento: tinha enorme diffienldade em respirar, pontadas, arripios, ete. 0 dr. Stroëhlin, mma eelebridade medica, den-me conno remedio infuscies de hera e, eomo bebilla, leite; anbas as bebidas, eran adoçadas eom mel em rez de assuear. Usei dons dias este medicamento e fiquei completamente eurado."

Hôr de colica. Desapparece após a absorpção de algumas durias de colheres das de sopa, de mel.

Elcctuario anti-hemorhoidul Russ. Maná sessenta grammas, sulfato de potassa dez grammas, nitrato de potassa dez grammas, enxofre hydratado dez grammas, mel branco dez grammas. Usa-se na lóse de oito a quinze grammas por dia.

Tisma peitoral. Folhas seccas de avenca dezesete grammas, de veronica dezesete grammas, hyssopo dezesete grammas, 
hera terrestre dezesete grammas, escolopendra dezesete gramnuas, capsula de papoula branca dezesete grammas; fervem-se na agua precisa e reduz-se esta depois ao lume até cincoenta grammas, que se filtram e misturam com cincoenta grammas de mel branco.

Mel de borax. Este mel é muito proveitoso nas affecções aphtosas e um bom parasiticida e desinfectante. Prepara-se misturando trinta grammas de mel com quatro grammas de borax.

O Oximel simples, bastante usado como tisana temperante nas febres inflammatorias, obtem-se fazendo uma mistura de quinhentas grammas de vinagre branco com duas nil grammas de mel; leva-se, cozendo-o ao fogo, á consistencia de xarope e emprega-se na dóse de sessenta grammas de oxinel para cada kilo de agua ou tisana.

Mel de mercuriaes. Succo de mercuriaes e mel partes iguaes, evaporadas em consistencia conveniente. Applica-se na dóse de cincoenta a cem grammas em clyster.

Externamente o mel é usado nos seguintes casos:

Ulccras e abcessos. Mel quente amassado con farinla de centeio ou cebollas assadas. Dispôe-se este unguento sobre as feridas, envolvendo-as em seguida com um panno de linho.

Dôres de garganta. Amassa-se mel quente,-farinha de centeio, uma gemma de ovo e manteiga, e deita-se a massa em um panno, que se pôe ao pescoço.

Dồres sciaticas. Fricções repetidas e demoradas de mel e cal viva, misturados.

Doenças dollios. Se o mal fồr intenso applica-se, ao deital e levantar, duas on tres gottas de mel puro, nos ollos do padecente; se o incommodo fòl leve basta lavar os olhos meia duzia de vezes por dia, com uma mistura feita a quente de mel e agua em quantidades iguacs.

Conservaçáo do eabello. Para conservar o cabello, evitando-lhe a quéda, deve cmpregar-se usualmente a seguinte pomada: nieio kilo de mel, sessenta grammas de gordo de boi e cento e vinte e cinco grammas de balsamo de Perú, derre- 
tidos juntos e aromatisados, quando estiverem quasi frios, com uma gramma de oleo de cédro, uma gramma de oleo de noz muscada e tres decigrammas de almiscar.

Qncimaduras. As queimaduras e escaldadellas, curam-se de prompto, sem harer inflammação nem dôr, applicando, inmediatamente após o accidentc, uma camada de mel sobre a parte ferida, camada que se renora de hora em hora.

Verrugas. Voiblet aconselha para fazer desapparceer as rerrugas das mãos, esfregal-as com mel o maior numero de rezes possivel durante o dia; ao deitar esfregam-se tambem com mel e rcstem-se umas luras. Ein poucas semanas de tratamento a pelle está fiuissima e livre das tão desagradaveis e inconmodas excrecencias.

Ciciro. O cieiro dos labios, face e mãos desapparece de prompto com umas friç̧ôes ao dcitar e levantar, de una pomada fabricada de metadc e metade mel. e azcite, ou mel e tcrebinthina, ou mel e cêra, derretidos juntos.

Inflammação e foridas do naris. Tratam-se applicando-lhe, com uma penna, durante quatro ou cinco dias, mel puro, e, depois de bem lavadas com agua tepida, passando repetidas vezes sobre a parte doente, oleo de linhaça.

Conservaçono da cutis. Conserva-se perfeitamente a cutis com o uso do sabão de mel, que se manipula amassando cincocnta grammas de boul sabão branco com cento e trinta grammas de mel, dezeseis grammas de oleo de tartaro e setcnta grammas de agua de flôr de laranjeica.

Tumôres. Fazcm-se rebentar de prompto, pondo $\mathrm{cm}$ cima uma massa coniposta de uma nistura ben batida, de metade $e$ metade, gemmis d'ovos a mel.

Rhcumatismo. Quando não lesappareçam de todo, diminuem muito as dôres rheumaticas com friç̧̃es do mel, quatro ou cinco rezes durante o dia. Duas das friç̧ôes deven sel dadas, uma ao deitar e outra ao levantar da cama.

Mcl eyyptiaco ou cseharotico. Mel duzentas e oitenta grammas, vinagre cento e quarenta grammas, rerdete cen grammas. Mistura-se e faz-sc eraporar até á consistencia de mel. 
Mel mercurial. Mel cento e rinte grammas, mercurio doce cincoenta grammas. Topico nas uleerações venercas.

Mel terebinthinado Martinet. Mel rosaro cento e cincoenta grammas, essencia de terebinthina dez grammas. Usa-se na dóse de tres colheres por dia contra o rleumatismo lombar, as nevralgias e a sciatica.

Unguiento de Pilérit. Mel duzentas e rinte grammas, polpa de cebolla duzentas e vinte grammas, cêra antarella quarenta e duas grammas, resina quarenta e duas grammas, sabão negro quarenta e duas grammas. Contra as feridas rebeldes.

Na medicina reterinaria é que o mel tem uma constante e benefica applieação.

o Rucher Belge, celebra-lhe assim as suas propriedades boas na cura das doenças dos animaes:

«() mel é vantajosamente utiiisado na medicina dos animaes domesticos. No que não ha vautagem é empregal-o só, pois a sua efficacia accentua-se muito mais misturado com certos medicamentos, que são então mais faceis de administrar e prodnzem melhor effeito. O mel n'este caso alquire propriedades euratiras, que não teria de per si, de modo que a efficacia da mistura é superior aos effeitos das diversas substancias empregadas em separado.

$\hat{E}$ pois muito vantajoso reduzir a pó as substancias mredicamentosas mineraes ou vegetaes, para as associar ao mel, sobretudo nas doenças das vias respiratorias (anginas, pneumonias, plenresias, bronchites, ete.).

Certos animaes, depois de alguns dias de tratamento, véem muitas rezes de per si procurar o medicamento, attrahidos pelo sen sabor assucarado, evitando assim a applicaçĩo de beberagens difficeis de fazer engulir aos grandes animaes.

Os lavradores perdem frequentemente os vitellos, alguns clias depois do nascimento, en rirtude de uma diarrhéa que espantosamente os enfraquece e mata.

É um medicamento heroico contra esta doença, que a eura cm poncos dias, o uso de agua c mel.

O mel entra tambem na preparação de 1 m remedio que serve para o tratamento do sapo, a conhecila doença dos cascos do cavallo, tão tenaz e tão difficil de eurar.

Faz partc igualmente de certos unguentos proprios para conser- 
var a flexibilidade dos cascos dos pés dos carallos, esses bons animaes que são, inquestionarelmente, os mais preciosos auxiliares do homem. Eutra tambem em mnitas pomadas que favorecem a cicatrisação das feritas.

Em medicina veterinaria, o mel serve constantemente para nso interno e externo, e um proprietario cnidadoso com a sande do seu gado deve ter sempre em casa mma boa provisão d'elle».

Afóra estc uso geral, o mel entra na confeeção de numerosos preparados cujas formulas fơram por nós colhidas não só no nosso paiz mas tambem em dirersas publieaçôes estrangeiras da especialidarle, e que são as seguintes:

Febre aplitosa. Esfrega-se a lingua e rentas do animal com mel c as unlas eom uma mistura de partes iguaes de mel, rerdete e unto.

Laratorio emolliente. Cozimento de linhaça novecentas grammas, mel norenta grammas. Junta-se, eôa-se e administra-se cm lavatorios nas aphtas.

Laratorio ardstringente. Cozimento de easea de salgneiro mil o oitocentas grammas, mel sessenta grammas, acido muriatico tres oitaras.

Administra-se em lavatorio no euratico de feridas de mau caracter.

Carbunculo. Emplasto de papas de linhaça amassadas com mel.

Constipargão. Como belida adoraute: agua nove litros, ccralla trezentas e oitenta grammas, mel meio kilo. Em duas veres no dia. Como bebida emolliente: agua quente dez litros, linhaça cento e trinta grammas, mel cento e trinta grammas. De duas vezes. Como belide diuretica: agua quatro mil grammas, vinho branco quatro mil grammas, salitre noventa gramnas, mel cento e trinta grammas. Eim tres dóses.

Diarméu. Bebida opiada White: agua setccentas e cincoenta granmas, mel seteeentas e eincoenta grammas, opio eineo eentigrammas.

Docuras dollos. Derrete-se em banho maria duzentas grammas de mel e duzentas grammas de unto de porco; esfre- 
ga-se com a mistura o olho doente tres ou quatro rezes por dia, soprando fortemente, em cada applicação, sobre o olho, para bem estender o remedio.

Gosma, constipação, defluxo, etc. Pó de alcaçuz trinta grammas, pó de althêa trinta grammas, opio uma gramma, mel trezentas grammas.

Tosse. Ipecacuanha quatro grammas, camphora oito grammas, alcaçuz quinze grammas. Rcune-se-lhe o mel sufficiente para se poderem manipular doze pilulas.

Feridas dos amimaes. Curam-se de prompto cobrindo-as com uma pasta de mel e farinha de trigo.

Electuario. Assafétida duas oitavas, raleriana em pó oitcnta e quatro grammas, camphora em pó duas oitavas, mel duzentas e cincoenta grammas.

Em duas dóses contra as perturbações do systema nervoso.

Electuario aperitivo Hayne. Em caso de fastio nos grandes animaes mistura-se-lhe ans alimentos o preparado que segue: sal sessenta grammas, genciana trinta grammas, mel duzentas grammas, farinlıa trezentas grammas.

Electuario exeitante. Canella em pó vinte e oito grammas, raiz de angclica vinte e oito grammas, hydrochlorato de ammoniaco quatorzc grammas, mel duzentas e trinta grammas.

Administra-se por uma só vez aos animaes grandes contra a paralysia.

Beberagem vermifuga. Batem-se quatro gemmas d'ovo com trinta grammas de cssencia de terebinthina e duzentas grammas de mel e, depois de bem batidas, reune-se-lhe mil grammas de vinho branco.

Beberagem uterina Dorrault. Nos partos laboriosos das eguas e raccas applica-sc a seguinte bcberagem: cravagem (esporão de centeio), pulverisada, trinta grammas, vinho tinto mil grammas, mel duzentas e cincoenta granmas.

Bebida refrigerante. Agua mil grammas, mel cento e cincoenta grammas, vinagre setenta e cinco grammas.

Bebida peitoral. Figos passados cento e doze grammas, raiz de malvaisco oitenta e quatro grammas, agua duas mil e 
setecentas grammas; faz-se cozimento, còa-se e junta-se-lhe cento e doze grammas de mel. Administra-se aos animaes grandes em duas dóses durante o dia, e aos pequenos em quatro dóses.

Bebida tempercunte. Folhas de azedas seis mão-cheias, que se cózem en nil e quinhentas grammas de agua, côa-se 0 todo e junta-se-lhe sessenta grammas de mel. Applica-se em duas dóses, para os animaes grandes, contra febres, inflammaçũes, etc.

Bcbida refrigcrante. Folhas rerdes de borragem, seis mãocheias, que se põem de infusão en dous mil e setecentos litros de agua. Côa-se e addiciona-se-lhe cento e quinze grammas de mel. Em duas dóses contra molestias de peito e vias urinarias.

Bebida adstringente. Rosas vermelhas tres mão-cheias, casca de romã tres mão-cheias; coze-se tudo em mil e setecentas grammas de agua, côa-se e addiciona-se-Ihe vinte e oito grammas de borax e norenta grammas de mel. Em duas dóses contra congestões sanguineas, diarrléas e suores abundantes.

Bebida culstringente opiada. Com a mesma applicação prepara-se esta bebicla, mais fórte, do seguinte modo: raiz de bistorta sessenta grammas cozidas em mil e setecentas grammas d'agua; côa-se e junta-se-lhe extracto aquoso d'opio meia oitava, mel noventa grammas.

Bcbida drastica. Sulfato de magnesia cento e doze grammas e tartaro emetico meia oitara dissolvidos em mil e oitocentas grammas de agua; junta-se-lhe, por ultimo, sessenta grammas de mel.

Em duas lóses aos animaes grandes.

Belvida dimetica temperante. Vinagre cento e doze grammas, agua mil e quatrocentas grammas, nitrato de potassa oitenta e quatro grammas, mel cento e setenta grammas.

Applica-se por duas rezes em novecentas granmas de cozimento de grama, aos animaes corpulentos, contra as inflanmações agudas das vias urinarias.

Bebida peitoral expectorante. Agua mil e oitocentas gram- 
mas, mel cento e sessenta e oito grammas, malvaisco em pó oitenta e quatro grammas, kermes duas oitavas.

Em duas dóses, uma de manhã e outra de tarde, contra os catarrhos chronicos.

Pilulas purgativas. Aloes (azebre) trinta e cinco grammas, alcaçuz sessenta grammas, mel trinta grammas. Preparam-se as pilulas, que se applicam de manlãa, uma por dia.

Gargarejo. Infusão de rosas vermelhas mil e oitocentas grammas, acido chlorlhydrico diluido vinte e oito grammas, mel cento e setenta grammas. Contra a angina.

Injecrio temperante. Cozimento de cerada mil e oitocentas grammas, alcooleo sulphurico quatorze grammas, mel cincoenta e seis grammas. Applica-se em injeç̧̃es no curativo das ulceras fistulosas.

Excitante uterino. Cravagem (esporão de centeio), em pó, rinte e oito grammas, mel cento e sessenta e oito grammas, rinho tinto mil e oitocentas grammas.

Administra-se em duas dóses nos partos demorados por inercia do utero.

Clyster narcotico. Folha de belladona vinte e oito grammas, agua mil e quatrocentas grammas. Faz-se cozimento, côa-se e junta-se cento e vinte grammas de mel.

Administra-se em dous clysteres nas diarrhéas, superpurgação, nevralgias, etc.

Unguento adstringente e resolutivo. Seis claras d'oros, alumen em pó cincoenta e seis grammas, aguardente oitenta e quatro grammas, mel duzentas e trinta grammas.

Serve-se para applicar em fios, ou em panno, nas ulceras, e é rutil nas inchações edematosas.

Unguento para eonserrar os easeos. Oleo de mentastro, cêra amarella, banha de porco fresca, resina pura, terebinthina e mel sessenta grammas de cada substancia; misturam-se, derrete-se a fogo brando, côa-se e unta-se us cascos com una pequena porção d'cste unguento.

Unguento para endurecer os caseos. Alcatrão cincoenta e seis grammas, azeite de peixe cincoenta e seis grammas, cebo 
de carneiro cincenta e seis grammas, sabão ordinario rinte e oito grammas, mel cinco grammas, terebinthina cinco granmas, cềra amarella quatorze grammas. Derrete-se tudo a calor brando e côa-se.

Serve para untar os cascos.

Ferillas llos cascos dos curallos. Prepara-se para este fim o seguinte unguento. Aquecem-se mil grammas de mcl, e reunem-se-lhe pouco a pouco sessenta e quatro grammas de noz de gallia, sulfato de zinco e acetato de cobrc cento e rinte o oito grammas, retira-se o todo do fogo, deita-se-lhe trinta e duas gramnas de bichlorureto de mercurio pulverisado e mexe-se até arrefecer.

Masticulorios. Dá-se este nome ás substancias introduzidas em um pequeno saco de panno de linho, na bòca do animal, e presas com uma fita, quc, salindo dos dous lados da bòca, atam na cabeça do aninal. Estes masticatorios são muito usados nas épizootias e nas ulceras da bôca.

Masticalorio anlipulrillo Robiuct. Mel cento e rinte grammas, alho oito grammas, sal vinte grammas, pimenta trinta grammas.

Masticatorio adorqule. Quantidarles iguaes de mel, pó de alcaçuz, pó de althêa e pó de gomma arabica.

Masticalorio peiloral para os bois e carallos. Mel seis grammas, figos triturados duas gramnas, raiz de alcaçuz em pó cluas grammas. 


\section{As substancias produzidas-A cêra}

\section{- Extracẹ̃̃o, purificação, usos e falsificações da cêra}

Acreditou-se durante muito tempo que a cêra era proveniente do pollen das flôres elaborado no estomago das abelhas e expellido pela bôca. Reaumur sustentou esta opinião em 1740 e, atć 1768, foi ella geralmente seguida, mas n'esse anno Imm desconhecido, por intermedio de Wilhelm, participou a uma sociedade de apicultura allemã, que observára quc a cêra era segregada pelos anneis da parte posterior do corpo. Mas cstas observações foram rejeitadas como erroneas, por isso que iam de encontro ás expendidas por um sabio, então indiscutivel, o grande Reaumur.

Em 1792, o medico inglez Hunter, affirmando que a cêra mão ć proveniente do pollen, por isso que as abelluas que tinham os alreolos completamente construidos e com oros, é que recolhiam mais pollen, em maior quantidade do que as abelhas novas, que o deriam n'esse caso necessitar para a formação dos favos, chega á arrojada conclusão de que o pollen cra para sustento das larvas e a cêra não passara de uma secreção dos folliculos collocados sob os anneis inferiores do. abdomen.

Huber, que tambem scguia esta mesma opinião, resolven proval-a experimentalmente. Para isso alojou $11 m$ enxame sahido d'uma colmeia mãe, n'uma colnueia vasia com mel e agua; feclia-lhe as portas para que nenhuma abella possa 
sahir, deixando apenas pequenas passagens para a renovação do ar. Estas abelhas priradas do pollen segregaram comitudo eêra, fazendo em cinco dias cinco bellus faros. Podia-se comtudo objectar que as abellias, antes de serem encerradas na colmeia tinham absorvido pollen, e que, d'esse pollen assimillado, o que era produzida a cèra, e por isso Huber prolonga a experiencia nas mesmas abelhas tirando-lhe os faros cinco vezes sem que ellas parassem de os eonstruir. Em seguirla faz a experiencia em sentido contrario. Priva um enxame de mel e agua e dá-lhe sómente pollen. As abelhas vivem mas não segiregam eêra. Repete novamente as experiencias substituindo o mel por assuear reduzido a xarope e as abellas continuan ainda a produzir cêra, mas em quantidade muito menor do que quando eram sustentadas a mel. Logo a cèra não é mais do que um resultado da elaboração do mel ou substaneias assucaradas no estomago das abellias, sendo necessario, termo méclio, sete grammas de mel para produzirem uma gramma de cèra. As abelhas novas são as que segregam mais cêra.

A cêra da Apis mellifica e A. ligustica funde a $63^{\circ}$ e $64^{\circ}$ eentigrados, anollece a $35^{\circ}$ e a sua densidade é quasi igual á da agua 0,966 . É insoluvel na agua, muito soluvel nas gorduras, azeites, benzina e sulphureto de earbone. Pela destillação a seeeo produz varios acidos e muitos carboretos de liydrogenio.

Fazendo reagir acido azotioo sobre cêra produzem-se aeirlos margaricos, pimelicos e rarios muitos outros. A cèril, tratando-a eom lexirias concentrarlas rle potassa, transforma-se em sabões solureis, e, aqueeendo-i com cal potassada, produz um sabão d'onde se extrahe o aeido stearieo, que, por uma ulterior oxydação, se converte em acido margarico.

A unica differença que existe entre os corpos gordos ordinarios e a cèra é uma oxydaçio mais oll menos arançada. Purifieada pela ağua a ferver e pelo alcool frio, llá a cèra dous prineipios immediatos a crine, ou aeido cerotieo, que se derrete a $70^{\circ}$, é soluvel em dezeseis partes d'aleool ferrente, dá uma reaeção aeida sobre o papel de tournesol, emquanto a 
ontra, quasi insoluvel no alcool e mesmo no ether a ferver, se chama myricine.

Apparece tambem na cêra, mas em pequena quantidade a céroileme, substancia extremamente molle, derretendo a $28^{\circ}, 5$, muito soluvel no alcool e ether frio, e acidulando o papel de tournesol.

Ignora-se o que dá as côres variadas á cêra, que, na sua origem, é branca; presume-se ser as emanaçóes dos corpos das abelhas, emanações que, variando com o sustento e natureza lo sólo, fazem a cêra ora vermelha, ora amarella, com todas as differentes muances que vão do amarello limão ao verde.

A cêra é um producto de altissimo valor; que não abundla no nosso mercado. Portugal não produz cêra para o seu consumo interno, tendo de importal-a, de utilisar cêra vegetal, quando pódc e dere ser um bom exportador de mel e cèra, que hão le dar lucros seguros ao apicultor illustrado.

A apicultura mobilista, industria rerdadeiramente moralisadora, quando estiver larganente espalhada, como nerece, no nosso paiz, lia de concorrer para a cultura de muito terreno abandonado, para a creação de prados e florestas de essencias proprias para a alimentação da abetha. E, quando abundar o mel puro e bon, ha-de surgir a industria do pão de especies, dos rariadissimos doces de mel, dos licores de mel, do liydromel, etc., con que os francezes e os allemães opulentam as suas mesas. Parece-nos que tambem todos os consumidores anciarão pelo dia, em que a cêra seja tanta que substitua em torlas as casas as detestaveis velas de productos inclassificaveis, que sĩo o nosso martyrio e o nosso descspero.

A cềra cm bruto, quando não reduzida em pães fórtemente comprimidos, e atacada por duas especies de borboletas, a que vulgarmente dão o nome de timhas (Galeria cerella e Galeria alcenia), que, quando a não destroem de prompto, the firzem, pelo menos, perder bastante do seu valor commercial. Estas borboletas depõem os ơos na cêra, principalnente nos faros velhos; d'estes oros sahem larvas, que viven á custa da cêra, atravessando-a com galerias e reduzindo, em pouco tempo, 
enormes massas de cèra a uma massa esponjosa de cheiro nauseante.

Para evitar estes estragos, logo que os faros fican sem mel, lavam-se cuidadosamente en agua quente, e, issim que estão desembaraçados, das materias assucaradas que continham, guarlam-sc en caxas hermeticamente fechadas, onde se queima enxofre em pó, ou, mellıor, meehas de enxufre, para os rapores sulfurosos matarem us ovos de tinhas que possam existir nos favos.

Convém aqui recordar que as aguas de lavagem dos farus, aguas que conteem ainda muito mel, serven para o fabrico do liychomel, de vinagre de mel, ou podem ser aproveitadas para serem distilladas e produzir aguardente de mel, que é magnifica.

Guardados nas caixas, eomo acima deixamos dito, os faros pódem esperar pelo momento em que o apicultor tenha mais vagal para tratar cuidadosamente do preparo da cêra. Esta oeeasião eliega quando os primeiros frios reduzem a muito pouco os enidados a prestar ás colmeias e á sua população. Então, trata-se da purificação da cèra.

Como é sabido, os favos eonteen sempre impurezas, isto é, pollen, pó, fragmentos de larras, abellas mortas, ete.; impurezas estas que só se pódem tirar pela fusão.

Esta fusão, ou derretimento da eèra, faz-se por meio do ealor solar uu sob a influeneia do fogo. O apparelho utilisavel, no primeiro caso,

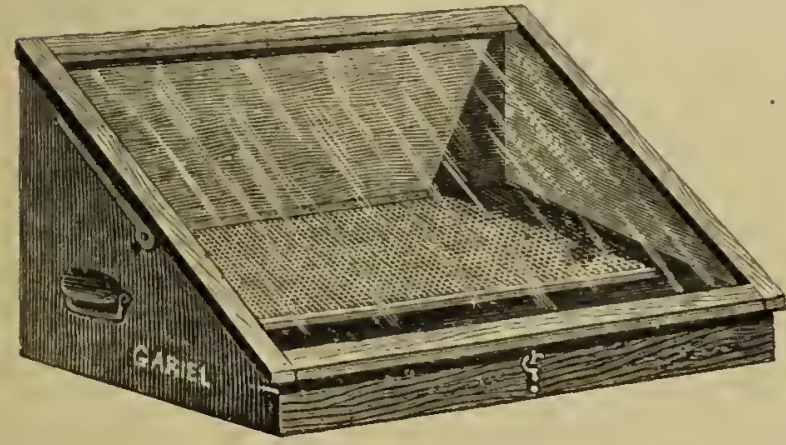

P'urificador' solax tem o nome de purificarlor solar e eonsiste em uma eaixa de madeira de fundo horisontal de $65 \times 50$ eentimetros, com parcdes verticaes de tamanlıos desiguaes, tendo a de traz a 
altura de trinta e dous centimetros e a da frente de seis centimetros, o que faz com que a cobertura, que ó de vidro, possua una considerarel inclinação de traz para a frente. $O$ quadro, quc serve de tampa, e que sustenta o vidro, tem atras dobradiças e na frente un gancho, que serve para a ter hermeticamentc fechada. Exteriormente a caixa é pintada de preto e gira sobre um eixo, para seguir o sol na sua marcha, e receber-lhe sempre os raios. Interiormente a caixa tem um fundo duplo mobil, de lata, de $62 \times 41$ centimetros, sustentado por travessas pregadas nas paredes lateraes e inclinado de traz para diante, com uma inclinação de dez centimetros por metro. T'res dos bordos d'esta folha de flandres são dobrados approximadamente um centimctro para cima e o da frente ć dobrado por baixo. A dous centimetros por cima d'este duplo fundo está collocado un quadrado feito de teia metallica; as dimensões da folla de flandres são taes que entre ella e a parcde dianteira da caixa póde collocar-se uma pequena tina de lata do mesmo comprimento que a caixa.

A cèra diridida á mão, en pequenos fragmentos, é deitada em cima da teia metallica; depuis fecha-se cuidadosamente a caixa e colloca-se em sitio bem exposto ao sol. Os raios solares, passando atravez do vidro, elevam a tenperatura do interior da caixa; a cêra começa a derreter a $64^{\circ}$ para correr liquida entre $73^{\circ}$ a $\$ S^{\circ}$. Derretendo, cahe sobre a placa de follua de flandres e corre para a tina, onde fica moldada em pães de tamanho regular.

Esta cêra é mais bella e de melhor aspecto do que a obtida pelo derretimento ao fogo, mas este processo só póde. ser aproveitado para o derretimento de pequenas porções de cêra.

Industrialmente, para a manipulação de grandes massas de cêra, ć preciso o tratamento ao fogo.

- Para isto é indispensavel uma caldeira grande, onde se derreta a cêra, vasos levemente conicos para derretimento da cêra, um coador com pć comprido ou duas azas, uma pá para mexer e uma colher de paụ. 
Deita-se agua na caldeira até metade da altura e põe-se ao fogo: $\log 0$ que a agua estiver a ferver, enche-se a caldeira de cêra, dividida á mão em pequenos fragmentus, até dous terços de altura; mexe-se até haver fusão cumpleta, tendo muito cuidado en que a cêra, que é muito inflammavel, nîo trasborde sobre o lume. Quando a cèra derreteu por completu, deita-se o liquido nos rasos conicos, mexendo sempre com a colher, e fazendo passar todo o liquido pelo coador, onle fieam as impurezas que, fincla a operação, se deitam fóra.

Os rasus conieos ou fôrmas, que pódem ser de barro vidlado, ou melhor, de lata ou zinco, de dimensões proprias para dar pães de cêra do peso de dous kilos, collocant-se en sitio abrigado, envoltos en palla ou pannos grossos, para que a eêra arrefeça lentamente, afin de fiear bem limpa.

No dia seguinte a eêra está solidificada e tira-se da fôrma; no fundo da forma de cêra retirada ha uma maior ou menor eamada de impurezas, que passaram atravez do eoador e que foram juntar-se no fundo do raso.

Estas impurezas, a que dão o nome de pé de cềra, raspam-se eom uma faca de madeira ou metal. Estes pães de eêra apresentan coloridos diver'sos eonforme a região e o sustento das abelhas. Na região onde predominar o sanfcno, a cèra é arermellada; onde abundar a estera é amarella; onde lowver muitos prados e pomares é escura. A coloração é, enı geral, derida ao pollen com que as abeltas se alimentam de mistura com o mel.

Tamben se derrete ferrendo-a eom agua da ehura; a ec̀ra, sendo mais leve que a agua, rem á superfieie, d'onde se retira depois que arrefece.

Para que a cèra derretida por este processo fique um pouco mais limpa, muitos apieultores introduzem-a em $\mathbf{m}$ saeo de panuo muito raro, que deitam lia agua a ferver. Assim, a cèra, que passa atravez o teeido e vem á superficie do liquido, 6 geralnente pura, fieando as impurezas e os residuos maus 110 saeo.

Pareee que, addicionando a cada kilograumı de eèra a 
dcrreter um pouco de alcool e uma gramma de pedra lume por kilo, se facilita o deposito das impurczas.

Nas grandes extraç̧os utilisani-se prensas de enorme força, semellıantes ás de espremer o bagaço, para fazer fòrmas dc cêra, compactas e livr'es de todo o mel.

Nas extracções médias são muito empregadas ats caldeiras e marmitas,

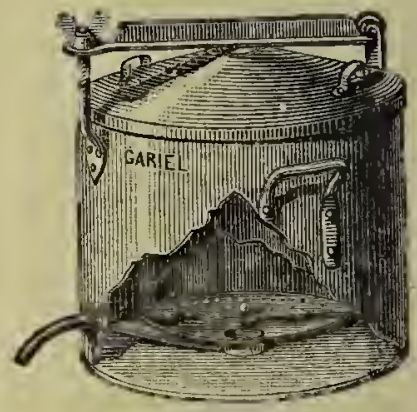

Caldeira Bourgeois para derreter a cêra a vapor quer para derreter a cèra a banlio maria, quer para a fundir a rapor. Esta cêra, salida das prensas ou calcadeiras, e cliamada cĉra bruta ou virgem, ć amarella e possue um cheiro de mel, rariavel segundo a qualidade das plantas que serviram de pasto ás abelhas.

Coino a industria reclama a cêra branca, é preciso, pois, quem quizer obter ainda mais lucro, clarifical-a, ou antes córal-a. Isto obtem-se, quel por nieios chimicos, quer por meios naturaes.

Climicamente emprega-se o acido sulfurico e o chlorureto de cal. A cêra, dividida em pequenos fragmentos, ć agitada com uma pequena quantidade de acido sulfurico diluido em duas partes de agua e alguns fragmentos de azotato re soda. A quantidade de acido nitrico que sc desenvolve, é o sufficiente para destruir o principio córante.

O embranquecimento por meio do chlorureto de cal é mais rapido, mas tem o inconrcnicnte de deixar na massa da cêra productos que desenvolvem acido chlorhydrico quando ardem as velas.

Os processos chimicos teem o inconveniente da cêra branca, assim obtida, ser muito sccea e quebradiça.

O processo natural, o unico usado entre nós, consiste na exposição prolongada ao sol. Córa-sc a cêra como se córa a roupa, expondo-a ao sol e conservando-a sempre hunida. Á cêra derretida en caldeiras proprias, addiciona-se duzentas e cincoenta grammas de cremor tartaro por quintal de cèra, 
depois faz-se cahir, liquida, em um vaso prismatico com uma ou muitas aberturas na parte inferior, pelas quaes a cêra corre sobre $\mathrm{nm}$ cylindro de madeira, cujo eixo é parallelo ao do raso, e estando em parte mergullado na agua.

Quanto a cêra chegáa á superficic do cylindro faz-se girar este lentamente. Por este meio a cêra estende-se em listões e solidifica pelo abaixamento de temperatura causado pela agna, que, molhando-a, impede as novas camadas de cèra de allierirem ás primeiras. Renova-se constantemente a agua da tina onde mergulha o cylindro, fazendo-a chegar ao fundo por meio de um tubo e trasbordar superiormente.

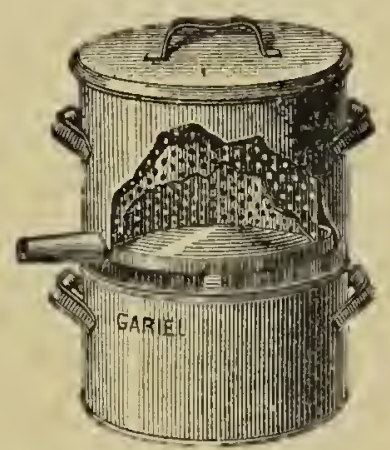

Marmita de lata parat derreter cêra a banho maria

A cêra assim preparada 6 disposta em eirados, durante semanas, dos raios do sol e ao orvatho, como se fa\% para o branqueamento das rompas.

A acçâno alternada do orvalio e do sol destroe pouco a pouco a materia córante tornando a cèra branca. Porém, se as laminas furem muito espessas, não brınqueam de uma só rez, sendo preciso derretel-as, laminal-as de novo e submettel-as a um segundo branqueamento.

Ha cêras que embranquecem rapida e facilmente em um ou dous dias e ha outras que levam tres, oito e ató quinze dias. Quanto mais tempo a cèra levar a embranquecer; tanto mais a sua qualidade ó inferior.

Depois de bem branca a cêra 6 disposta em pães, fórma em que usualmente se encontra no commercio.

Outr'ora, antes da descoberta do pergaminho e do papyrus, a cêra servia para cobrir as taboas onde se escrevia com o ponteiro, instrumento de metal aguçado de um lado para gravar as letrás e, largo e polido do outro, para as apagar.

'Tamben ela utilisada nos embalsamentos para encher as cavidades e cobrir externamente o corpo com uma especie de verniz, que o tornara incorruptivel. 
Hoje, além do largo emprego domestieo e religioso como substancia illuminadora, serve para confeccionar numerosos rernizes, 6 um bello auxiliar dos pintores, esculptores, gravadores, dentistas, - $\mathrm{c}$ até das costureiras - e magnifica para envernisal os soallos, para o que sc lhes applica uma levissima camada de cêra, esfregando depois com nuna escora fina até ficar brilhante.

A medicina igualmente se utilisa da cèra em muitos e rariados casos.

Eis alyumas das suas principaes applicações therapeuticas:

Ceroto para feridus inflammadas. Cêra uma parte, oleo de amcndoas doces, de linhaça, azcite, ou manteiga sem sal, quatro partes.

Dissolve-se a cêra no oleo quente c mexe-se ato arrefeeer.

Estc ceroto é muito bom para applicaçôes externas de rariadas substancias taes como quinino, camphora, opio, iodo, enxofre, jusquianı, etc. Histura-se com elle a substancia a empregar e fricciona-sc.

Pomada de terebintlina para as feridas sem inflammação. Cèra amarella vinte grammas, tcrebintlina vinte grammas, esseneia de tcrebinthina vintc grammas. Derrete-sc primeiro a cèra c reune-se-llıc a terebinthina e a esscncia.

Pomada para os labios. Cêra dez grammas, oleo de amendoas doces rinte grammas. Aromatisa-se emquanto quente eom qualquer esseneia.

Emplastro collunte para os golpes. Colophonia quarenta grammas, cèra quarenta e cinco grammas, resina elemi vinte c cinco grammas; derrete-sc e junta-se-lhe oleo de bergamota cinco grammas, oleo de craro duas grammas e oleo de limão duas grammas.

Cèru verde para os callos. Cèra amarella quatro grammas, resina branca duas grammas, terebinthiua de Veneza uma gramma, sub-acetato de cobre em pó fino uma gramma.

Derrete-se a cêra e a resina, junta-sc-lhe o acetato de cobre, anticipadamente bem misturado com a terebinthina, e mexe-se. 
Balsamo de Lausanna para o cieiro e fendas do seio. Azeite quinlientas grammas, resina de terebinthina suissa cem grammas, cêra amarella cento e trinta e tres granmas, raiz de soagen em pó vinte c cinco grammas; aquece-se a banhomaria durantc meia hora e addiciona-se-lhe balsamo de Perú dezeseis grammas, camphora nma gramma.

Cerolo simples para feridas. Cèra branca quatorze grammas, azeitc cincoenta e seis grammas. Derretidos e misturados a calor brando.

Ceroto de chumbo contra as ulceras fistmlosos. Cêra amarella cincoenta e scis grammas, sub-acetato de chumbo uma oitava.

Ceroto quinado contra as ulceras atonieas. Cèra amarella cento e quinzc grammas, extracto de quina trinta grammas.

Ceroto anodyno eontira as vleeras dolorosos. Cêra amarelta cento e vinte granmas, laudano liquido seis oitavas. Applica-se ell fios.

Unguento para as fendas dos caseos dos cavallos. Derrete-se em fugo brando partes ignuas de mel e cèra, que se misturam bem. Lavam-se os cascos dos cavallos com agua tepida e applica-se o unguento com um pincel.

Mistmra para eonservar o polido dos instrumentos diaço. Oleo de terebinthina oito grammas, cèra anarella uma gramma, oleo de linhaça fervido duas grammas.

O grande valor commercial da cĉra, faz con que ella seja objecto de numcrosas c constantes falsificaçōes. Misturam-lhe matcrias gordurosas, acido stearico, cebo, serradura de madeira, gesso, kaolino, ossos triturados, farinha, fcculas e tantas substancias rarias que scria difficil innumeral-as todas.

Ao lado da cềra das abellas tambem apparce a cêra de certos hemypteros e as varias cêras vegetıes, principalmente a êेra de palma provenientc da Ceroxilon andicola e a eêra do Brasil on Carmatba produzida pela Cmpernica cerifera, que são mais ou menos semelhantes á das abelhas, e diversas cêras mineraes on ceresinas provenientes da distillaçño de certos combustiveis fosseis. Mas, se estas cèras teem a còr, a consiş- 
tencia e a fractura da animal, não teem a sua densidade e fusão. Estas cèras, porém, misturadas com a cêra ordinaria e com stcarina, fazem com que seja muito difficil conhecel-as.

As cêras mineraes são hydrocarborctos, parentes proximos dos bitunes, produzidas por arrores resinosas sepultadas nas turfciras, e algomas, mas raras rezcs, das linhites ou furmaçôes hulhiferas.

Ha o osoliérite ou reresina (parafina natural) que se encontra em Inglaterra ou Caucaso e na costa occidental do mar Caspico; assemelha-se muito á cêra, mistura-se perfeitamente com ella en todas as proporçoes, molda-se facilmente o custa menos de metade. Dá esta cèra um bello gaz de illuminaçãu e, purificada, é mais proveitosamente cmpregada nas perfumarias e pharmacias que a cêra das abelhas, por isso que, além de gosar de propricdades antisepticas, impcdc os medicamentos de rancearem.

A hatchettine, que apparece cm Inglatcrra, Austria e Moravia, é pouco empregada assin como a neft-gil c a baïkerite do mar caspico.

Tambem apparece cêra em alguns bitumes, nas transudações de varias palmeiras, e nas picadas feitas nos vegetaes pelos inscctos hemiptéros-hontoptéros para lhe sugar a seiva, mas essa cêra é pouco aproveitada e sen valor algum comnercial.

A ceresina a substancia com que, como dissemos, mais usualmente falsificam a cêra, descobre-se derretendo em uma vasilla a cêra que se quer examinar c, em outra, pondo a dissolver a quente, em um pouco de agua, alguma sóda. Deita-se o liquido a fcrver sobre a cêra derretida e mistura-se. Se a cêra fòr pura fica por completo transformada em sabão. Sc, comprimindo um pouco entre os dedos pollegar e o indicador mollıados, um fragmento d'este sabão, elle não se desfizer por completo e ficar uma especie de massa mais consistentc, a cêra tem ceresina.

Igualmente se reconliece sc a cêra ó on não falsificada fazendo, por meio de um papel enrolado em um lapis, cylln- 
dros de papel, nos quaes se deita a cêra derretida deixando-a solidificar.

Depois de súlida introduzem-se os cylindros de cêra em um tubo de ridro que se enche de benzina.

Se a cèra fôr pura dissolve-se rapido e promptamente; se fòr falsificada a dissolução é imperfeita, ficando no tubo fragmentos mais on menos volumosos da substancia estranha, não atacavel pela benzina. 


\section{Inimigos e doenças das abelhas- A intelligencia das abelhas}

Como todos os animaes, e principalmente aquelles que vivem em sociedades numerosas, estão as abelhas sujeitas a varias doenças epirlenicas que, em annos pouco prosperos, as dizimam cruelmente, anniquilando colonias inteiras. A principal e mais commum é a disenteria, que grassa nos invernos prolongarlos, e que ataca geralmente as colmeias fracas. Esta doença é talrez derida á má alimentação e, principalmente, á imperfeita renoração do ar.

Os rapores aquosos são, no verão, expulsos da colmeia por meio de grupos de abelhas ventiladoras, mas esse trabalho não póde ter logar no inverno, por isso que as abelhas, entorpecidas pelo frio, se conserram amontoarlas no centro da colmeia, e então o ar, que não é renorado, rae-se saturando da humidade e acirlo carbonico que thes é muito prejudicial.

Este ar viciado, junto a uma alimentação deficiente ou constituida de mel corrompido ou muito aquoso, desenvolve-lhes a doença, fazendo com que, ao contrario dos seus habitos, pois normalmente as abelhas véem expellir os excrenientos fóra da colmeia, cubram as paredes da colmeia e os faros de materias fecaes, que exhalam um cheiro mephitico.

É preciso, quando grassar a disenteria em uma colmeia de população fórte, arejal-a bem, ou melhor, passal-a para nora 
colmeia. Se a colonia fơr fraca reune-se a una fórte e bem ventilada.

É $u m$ erro acreditar-se que o excesso de rentilação é prejudicial, mesmo na força do inrerno; pelo contrario ć util. A falta de ar é que, en regra geral, destroe numerosissimos enxames durante o inrerno.

Segue-se a loque ou podridño da ninhada, affecção que é, infelizmente, contagiosa em excesso. As larras on nymphas atacarlas tornam-se molles, côr de café com lcite, a pelle despedaça-se e o corpo decompũe-se rapidamentc, com um cheiro que enrenena, não só a colonia onde o mal primeiro appareceu, mas até as visinhas.

Como já dissemos, a criação, para se desenvolver, precisa de ser chocada com o calor das obreiras. Faltando este ellas morrem. Ora, havendo $\mathrm{nm}$ abaixamento inesperado na tomperatura, as obreiras são obrigarlas a agghlomerar-sc em um espaço restricto, deixando portanto sem calor uma parte da criação, que morre, decompondo-se, infectando o ambiente da colmeia, e fazendo com que o resto da criação, invadicla á sua rez pelo mal, apodreça tambem, o mel se corrompa, cnrenenando todas as abelhas que com elle se alimentarem. Estas, para fugir ao mal, abandonam rapidamente a colmeia, dispersando-se.

Tas o peor é que ficando a colmeia vasia é pilhada pelas abelhas das colmeias risinhas que, enchendo-se de mel, levam comsigo o contagio. Tambem muitas vezes parece que a loque é devicla ás obreiras alimentarem a criação, na falta de pollen fresco, com pollen velho e cormmpido; en regra geral, porém, o arrefccimento da criação é que parece ser a causa da sua morte e rapida corrupçĩo.

Reconliecido, pelo clieiro caracteristico, que se sente a distancia, que uma colmcia está invadirla pelo torrirel mal, se é um cortiço, passam-se as abellıas para um noro, queimando immediatamente o rello.

Se é uma colmeia morel mudam-sc só as abelhas para outra nora, tiram-se e queimam-se os quadros e faros e lavamse-lhe as paredes internas com potassa e depois com umas 
poucas de aguas limpas, deixa-se seccar, submette-se aos rapores de enxofre, e só se utilisa passado mezes.

É bom remedio para as abellas, quer atacadas pela disenteria, quer pela loque, unıa alimentação onde entre o boràx e o acido salicilico. Para isso fornece-se-lhe mel onde se dissolven, por cada meio litro, seis granmas de borax e seis grammas de acido salicilico.

Além d'estas duas doenças, as principaes e as que mais estragos causam, tambem as abelhas são invadidas pela constipação, pelo bolor, vertigem e narcotismo.

A constipação é devida a um abaixamento de temperatura na epocha de abundancia, quando estão com o estomago cheio de alimentos, que não pódem depois expellir.

Não thes é possivel então voar e vécm cahir, on fóra da colnueia, ou no fundo d'ella, onde morrem. Muitas vezes tambem concolre para a constipação, a alimentação feita con 0 mel armazenado tarde e que não foi operculado.

Descoberta a doença dá-se ás abelhas bom mel misturado com xarope de assucar espesso, e, no ultimo extremo, passam-se para uma colmeia nova.

O bolor é derido a uma decomposição dos faros pelo cxcesso de humidade e falta d'ar. Evitando as causas, como é de prevêr, cessam immediatamente os cffeitos.

O narcotismo c a rertigem, em que as abelhas não pódem voar c cahem entorpecidas por un certo espaço de tempo, parecem ser incommodos devidos á absorpção do nectar renenoso; produzen o narcotismo especialmente o nectar das flôres do linho e de certas umbelliferas, e a vertigem o nectar das tilias, e o nectar e pollen dos eucalyptos e das camellias.

Afóra cstas doenças, ha no mundo vegetal e animal numerosos inimigos, potentes saltcadores que atacam e matam as pobres abelhas, que a ninguem incommodam, contentando-se completamente com o bom sol de verão, e o pollen e o nectar que corre das flôres.

Mas, se de emboscada, são subjugadas e rencidas, apresentando-se o inimigo frente a frente, sem recorrer a ciladas 
nem a traições, as abelhas combatem-o imparidas mostrando, em sanguinolentas refregas, que as obreiras da paz são as mais valentes guerreiras quando defendem a familia querida e o lar amado.

Então é que ellas nos patenteiam a sua excepcional intelligencia, traçando planos de ataque e construindo trabalhos defensiros, que não é entĩo possivel attribuir ao instincto, mas unica e exclusivamente á intelligencia.

Naturalistas distinctos teem limitado simplesmente ao homem as manifestaçôes da intelligencia, que nos outros animaes substituem pelo instincto, innato, particular, cego, necessario e invariarel.

A intelligencia o electiva, condicional e modificarel segundo o meio e as circumstancias. Os animaes que aperfeiçoam as suas construccões, as adaptam aos variarlos terrenos, e receben a erlucação do homem mudando em virtude d'ella nĩo só o molo de viver mas tambem o organismo, fazem-o não instinctivamente, mas sim em resultado de actos puramente intellectuaes.

Ha comtudo un limite que separa a intelligencia do animal da do lomen, e esse limite é proveniente do animal ser desprovido d'aquella reflexão que, segundo a definição de Flomrens, ó «a fruculdade suprema que o csprivito do lomem tem de concentrar-se e estudar-se a si proprio.»

Quem é que não tem observado que os animaes rellos são muito mais astutos do que os novos, e risto as liçoes que os carnivoros dĩo aos fillos ensinando-os a caçar?

No viver familiar não vèmos nós, a cada passo, as liçóes que as gatas dão á prole, indicando-the as pessoas de casa, separando cuidadosamente aquellas que as tratan bem das indifferentes ou hostis e os graciosos ardis do que se serrem para a apanha das aresiuhas ou dos pequenos roedores?

Passando dos manmiferos ás aves, não vêmos n'estas reproduzirem-se factos identicos?

Os cuidados de que cercam os filhos, a aprendisagem do rôo, e o modo de se precaverem das armadilhas dos caçadores, 
são tambem manifestações claras do grande desenvolvimento intellectual dos animaes.

A sociabilidade é o signal da civilisação e da intelligencia.

As abellıns e as formigas não constroem habitações á semelhança das do homen, não teem governo estabelecido, não migram e fundam colonias?

Quando as abellas selvagens migram, antes de se darem ao trabalho de construir ninho, procuram as caridades de arrores já habitadas e abaudonadas por outros insectos da sua especie, e, só quando as não encontram, é que erlificam novas. Póde-se clamar a isto instincto, assinn como á engrenlosa distribuição do trabalho e da policia iuterna?

Não, mil rezes não.

As abelhas, nos casos ordinarios, dispõem os faros liorisontalmente, mas se estes, por um erro de calculo, ou por qualquer aceidente, soffrem uma dada inclinação, as abellıas, para aproveitar o pequeno espaço que fica rasio, constroen faros obliquos, chogando até a variar o desenho das cellulas.

Huber cobriu um dia uma parte das paredes internas d'uma colmeia fixa com laminas de ridro, de tal morlo dispostas que as abelhas tiveram de dar ıma grande inclinação aos faros para os poder fixar na maleira. Para, até certo ponto, compensarem o incommorlo e prejuizo que essa inclinação lhes tinha ido causar, mudaram o diametro das cellulas de modo a tornal-as maiores na parte convexa e menores na parte concara.

Has, un dia, faltando a $\mathrm{um}$ d'estes faros o apoio necessario, deslocou-se e ameaçou desabar, e logo os previdentes insectos construiram espeques, e ergueram columnas que eritaram o imminente desmoronamento.

As cellulas reservadlas para as prorisões são maiores que as outras, clıegando até vinte e dous millimetros; mas, quando o anno é fertil e a colheita abundante, augmentam as cellulas e dão-lhe um desenvolvimento em conformidade com o que lhes é necessario.

Quando o enxame sahe, ha um certo numero de abelhas obreiras que ficam vigiando cuidadosamente os alveolos reaes, 
não deixando salir as nymphas senão no momento necessario, e não permittindo á abelha mãe mais velha, matar as irmãs mais novas, senão depois de ter sido fecundida e estar, d'esta fórma, assegurado o futuro da colmeia.

As abelhas, reconhecendo claramente o inconveniento dos miasnas na saude publica, trazem para fóra tudo quanto morre dentro da colmeia. 'Mas, se o carlaver é corpulento, ellas, na impossibilidade de o arrastarem, cobrem-o de uma espessa camada de propolis, evitando assim o mau cheiro.

Teem no ultimo grau a faculdade de orientação; reconhecem a colmeia entre mil, e, agradando-lhe as flòres d'um campo, não só farem nesse amno a sua colleita exclusiramente n'elle, mas tambem voltam a procural-o nos annos seguintes. Maurice Girard eonta que $u m$ enxame se installou uma rez n'um tecto de uma casa começaurlo lá a construir favos. O

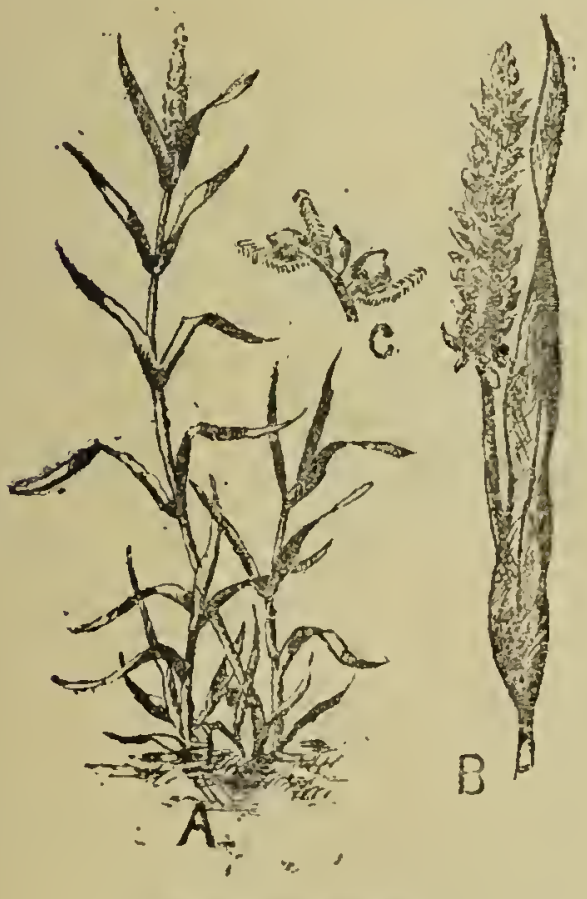

Setruia ereticillata

A Planta inteira $-\mathbf{B}$ Expiga $-\mathbf{C}$ Fraguento augmentadn da espiga mostrando as barbulas com arpõos dono do edificio recollieu as foragilas n'uma eolmeia propria. mas a primeira habita(iii) fôra tanto do agrado das abelhas que, durante oito annos, torlos os ellximes d'esta colmeia,-- só d'esta colmeia e nenlum dos das outras risinhas, - enviaram aniludadas rezes exploradores a reconhecel-o e visital-o. A recordaço do facto conserrou-se pois não só no primeiro enxame, mas foi igualmente transmittido a muitas gerações de descendentes.

Mas nãu sĩo micamente estes factos, ha muitos e muitos outros, especialmento as luctas com os inimigos, em que ellas mostram as 
maravilhas do seu engenho. São tantos e tão variados os combates a sustentar quantos os inimigos que teem a vencer e aniquilar.

Entre os vegetaes ha duas plantas destruidoras das abelhas, uma graminea a Setaria rerticillada ou Apanha abelhas, cujas paniculas são munidas de barbulas com finos arpões onde as abelhas ficam presas, e una asclepiade, a Arcuja cericifera, a

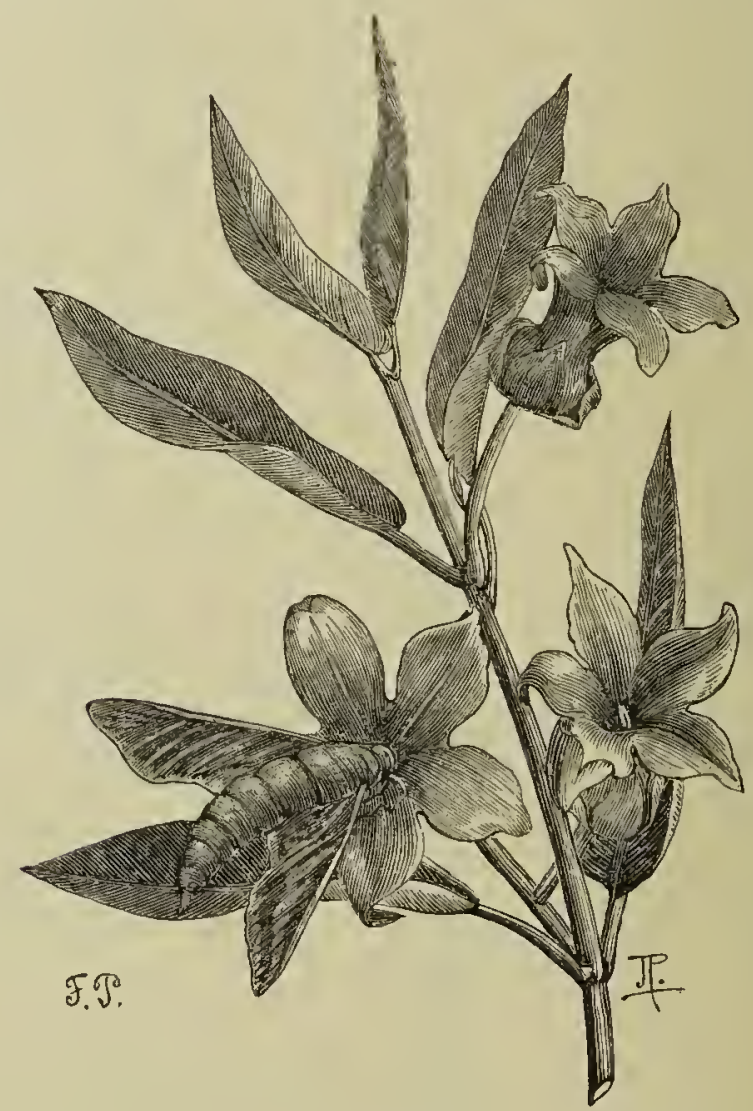

Ararja cericifera, com $n$ insecto preso na flôr

Summaúma, originaria do Brazil, ao presente muito espalhada entre nós como trepadeira ornamental. Esta planta cobre-se, durante grande parte do anno, de flôres, que produzem fructos grandes com numerosas sementes, terminando por corutilhos de natureza sedosa, muito utilisados para encher almofadas. 
A flôr d'esta Arauja cericifera é mortal para grande numero de insectos que, procurando colber o pollen e o nectar das flòres, fican presos no apparcho estaminal, na fenda do retinaculo, pela materia riscosa que elle contém.

Bellarochc referindo-se aos effeitos destruidores da Arauja cericifera nas abellias, diz:

"No verão, devido á abundancia das flòres as abelhas não procuram esta planta, porém em setembro e outubro a Arauja torna-se uma verdadeira apieida.

Obrigarlas pela fóme, e não tendo onde escolher, as abellias procuram esta flòr, e, apesar de lhes eustar a chegar ao retinaculo, tentann-se e, ou fieam presas, ou, após largos e eustosos esforços, conseguem sahir para eahirem eomo mortas no ehão, junto da planta. Observadas então as abelhas, parecem ador'meeidas, o que faz suppôr que a planta tem propriedades narcoticas. Esta hypothese é eorroborada pelo pronunciado eheiro de Stramonium que as follhas novas exhalam quando levemente

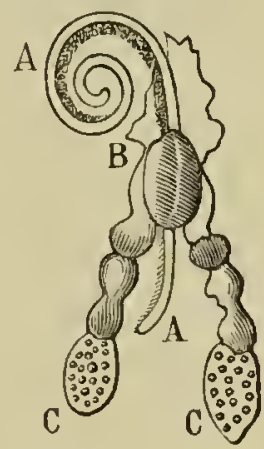

Apparello estaminal da Arauja cericifera

A. Tromba-B Retinaculo -C Massas pollinicas esinagadas entre os dedos. Estas abelhas, apparentemente mortas, no fim de alguns minutos agitam-se e fogem eom rôo ineerto e fraco, mas, eomo levam o retinaenlo preso á tromba, apertando-lli'a fórtemente, teem poucas probabilidades de virer.

Estamos eapacitados de que uma parede de certa extensão, forrada com esta trepadeira, é o bastante para dar cabo de uma colmeia. »

No mundo aninal encontram as abellas os seus nuaiores e mais pcrigosos ininigos em nns lepidoptéros do grupo dos microlepidoptéros, as tcrriveis tinhas, que põen os ovos nas flôres, entre o pollen, que as abelhas colhem e lcram para a colmeia; tambem, nutitas rezes, estas borboletas, quc são bastante corpulentas, zombando do aguilhão das abelhas, entram na colmeia e rão depôr os ovos nas proprias cellulas.

A timla, o lobo das abelhas como lhe chamara Swammerdan, ó tão antiga como as abelhas, c entre nós, os seus estragos são bastante perigosos, devido á doçura do inverno peninsular. 
Langstroth, diz, com razão, que a tinha vive ha milhares d'annos do trabalho das abelhas, e é um erro acreditar-se que é possivel exterminal-a.

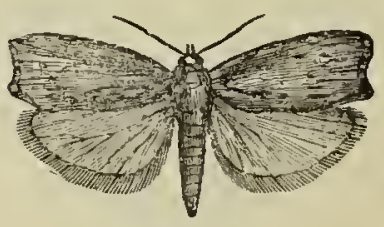

A tinha da cêra

A missão da tiuha na natureza, é destruir os favos abandonados pelas abelhas, os favos vellos e inuteis, ou os das colmeias sem rainha, cujas obreiras norreram. É raro a colneia que não tem alguma.

A tinha, conliecida e citada por numerosos anctores antigos, é uma borboleta nocturna, cuja larva on lagrarta se nutre de cêra.

Encontram-se em Portugal duas especies de tinlua, a Galleria cerella Fabr. e a Galleria alceria Dup.

A lagarta da $G$. cerella tem vinte a vinte e cinco millimetros de comprido por dous ou tres de dianetro, o corpo cylindrico annular, com dezeseis patas, ć de am branco sujo com pontos verrucosos isolados, e a cabeça preta. A larra da $G$. alcearia, assim

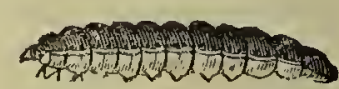

Larva ou lagarta da tinha como a borboleta, 6 um pouco mais pequena que a da $G$. cerella porém os seus estragos são identicos.

No estado adulto a $G$. cerclla tem quinze a dezenove millimetros de comprido, e as azas abertas vinte e sete a trinta e cinco millimetros de largura. Em repouso as azas superiores cobrcm as inferiores, mostrando-se quasi unidas sobre o dorso, e são erguidas nas extremidades fazendo lembrar a cauda das aves.

A femea é sempre maior que o macho e de côr mais escura, distinguindo-se facilmente do macho pelo labrum, que é alongado em fórma de bico.

As timhas são muito ageis, quer andando, quer roando, sendo difficil agarral-as:

"Não conheço, diz Reaumur, borboleta de pés mais leves; corre sempre, preferindo andar a voar, mesmo quando foge á mão que a quer agarrar. Quando anda, as azas estão pendentes, e, quando 
reponsa, estão dispostas em fórma de telhado mnito achatado. Vi ıma rez. em uma colmeia tres abelhas correren atraz d'uma borboleta d'esta especin, que andava deante d'ellas, melhor e mais depressa que ellas. Fez-lhes fazer muitas voltas até que se cançaran de a seguir e a cleixaram.»

Ao cahir da tarde, ou de manlã eêdo, rnam as tinhces á volta das eolmeias e, mal púdem entrar, depõen os oros nos faros abandonados, ou fóra nas fendas dos cortiçns; u'este segundo caso as larvas, logo que naseem, entran para o cortiço installando-se nos faros.

A larva sustenta-se da cêra,

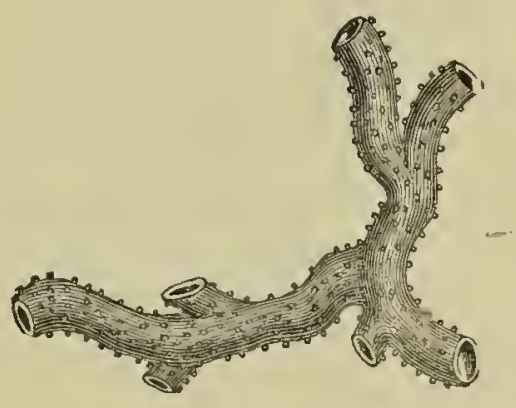

Galeria coustruida pola timla e isolada do favo onde cava galerias em todos os sentidos, que fórra con uma especie de sềla. Devora a cèra akançando de cabeça, e, á medida que vae roondo, vae angmentando e fortificando o easulo ou galeria, para se livrar dentro d'ella dos ataques das abellias.

- Assim sú expũe a cabeça, que é guarnecida de uma substancia eoriacea, que resiste ao aguilhão da abellı.

Os favos mais invadidos são os que tiveram creação e onde ella eneontra pollen, resto das pelles das larras, pois, eomo di\% o dóutor Doenhoff, não póde nutrir-se só de cêra pura, que não contém azote, alimento indispensarel para o sen perfeito desenvolrinento.

Talre\% por isso é raro ataear as laminas de eèra moldada. No fim de tres scmauas fórma easulo

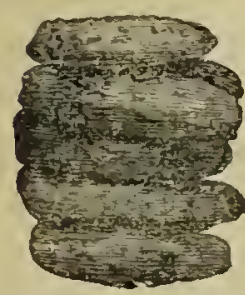

Casulos agglomerados da tinha on qualquer fenda, onle se transforma, en dez on doze dias, se a temperatura fòr elevada, e en mezes se fùr fria. T'emperaturas muito frias matam-a. Para teeer easulo tem de abandonar a galeria 0 ir procurar o sitio proprio para tal fin. Em colonias fracas o caso tem pouca inipol- 
tancia, mas em colonias fórtes é uma viagem perigosa, puis as abelhas espreitando-Ihe a sahida da galeria, e encontrando-a sem defesa, atacam- $\Omega$ e matam-a despiedadamente.

Pódem viver bastantes gerações de tinhas em um mesıno faro, pois faltando-the a cêra nutrem-se com os detritos deixados pelas gerações antecedentes, devorando até tecidos, papeis, couros e mesmo madeira!

A tirlia põe quasi logo que sahe do casulo. Põe todo o verão; os ovos, redoudos e muito pequenos, não tendo mais de quatro decimos de millimetro de diametro, são depostos pela femea em pequenos montões nos faros. Uma femea póde pôr duzentos ovos, que, na segunda geração, dão milhares, e na terceira milhões de insectos.

As larras das tinhas, alćm dos estragos que causam, espalham um mau cheiro na colmeia, que muito incommoda as abelhas. Conhece-se que ha tinha nas colmeias pelos excrementos que lhe cobrem o fundo.

Com as colmeias moveis pouco receio lıa da tinha, pois é facil procurar a lagarta, agarral-a com Pinça para agarrar as larvas das tinhas uma pinça e matal-a, risto que ella busca os cantos das colmeias e os encaixes dos quadros para se acoutar.

Com as colmeias fixas, e, prineipalmente, com o velho cortiço, o caso muda porém muito de figura.

Impedir-lhe a cntrada é impossivel, visto que ella entra por orificios por onde a obreira não póde passar.

Como, porém, só ataca favos abandonados, e nunca os faros 'com creação e cobertos pelas abelhas, é conveniente extrahir dos cortiços os faros velhos, que estão na parte inferior sem serem utilisados pelas abelhas. Isto, já se vê, entende-se com as colonias fracas, pois as fórtes, tendo os favos todos occupados, vigiam constantemente o inimigo dia e noite. As colonias fracas ou orphãs, não vigiam de noite, não se importando com nada e deixando, desanimadas, entrar livre- 


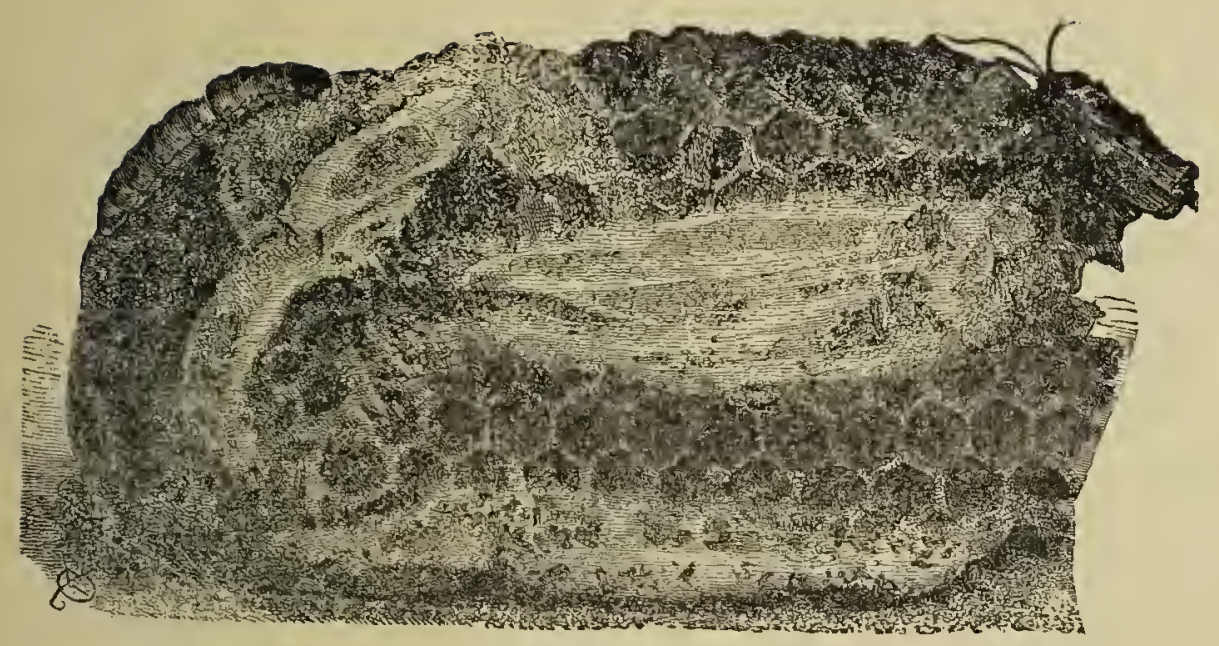

Favo atacado pela tinha

mente a grande destruidora da cêra rclha. O melhor meio desde o momento que uma colonia está muito atacada pela tinha, é leunil-a a uma outra livee do parasita, passando só as abellias, e destruir os faros pelo fogo, ou submettel-os aos vapores do enxofre muito fórte, durante pelo menos um dia, quando os quizermos aproveitar, pois os vapores de enxofre matan as timhes e suas larvas.

É preciso, qnando se reunem dous enxames com timha, projectal-os sobre um panno branco em communicação com a nora colmeia que thes é destinada, e haver o maximo cuidado em rigiar que as larras da timha não vão com as abelhas, pois deixam-se cahil de envolta com ellas, caminhando tambem apressadamente para a nova liabitação.

Pódcm-sc caçar as borboletas da tinha, pondo proximo do colmeal, nas noitcs escuras, uma luz sobre uma cchla d'agna com uma leve cantada le areitc á supcrficie; as borboletas, attrahidas pela luz, cahem e morrem afogadas no liquido. Tambem ó possivel apauhal-as com um lampeão de vidros plérianente untados com uma substancia viscosa, onde as borboletas se réem prender.

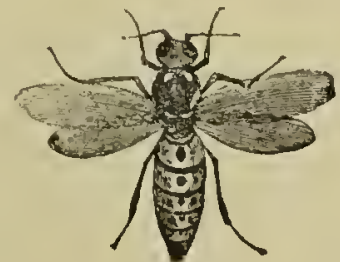

A vespa 
As respas, Vespa vulgaris, os vespões, abelhoes ou casacas amarellas, Tespa crabro, as grandes libcllinhas, as formigas, principalmente a Formiea truncata e as aranlias, tambem deroram as abelhas aos centos, mas não sen defesa, pois cstas conlbatem encaruiçadamente os inimigos que as assaltam, matando-os muitas vezes a golpes de aguiHhão ou desperlaçando-os com as mandibulas.

Os caracoes e as lesmas introduzem-se frequentemente nas colmeias

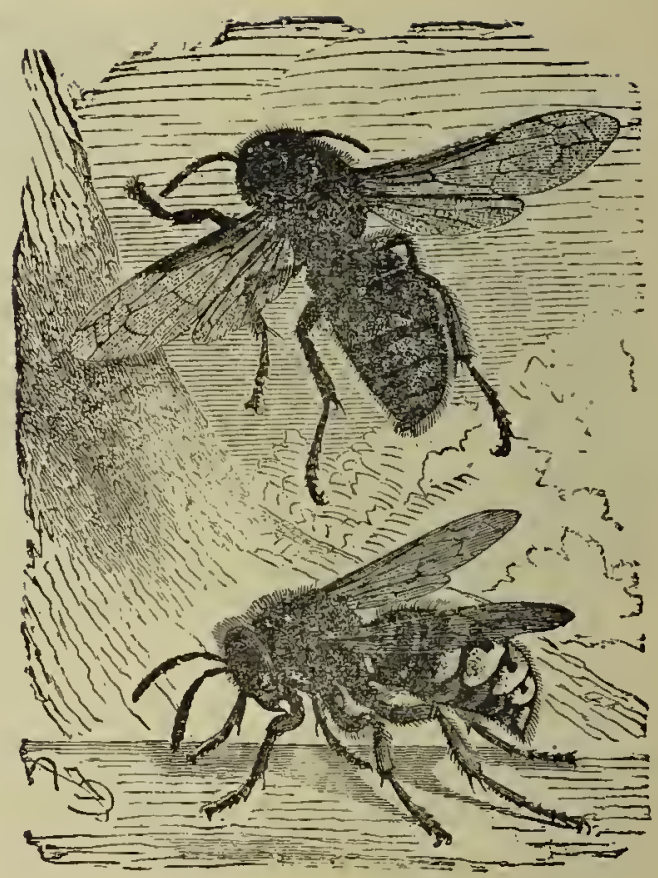

Os vespòes á procura de mel; as abelhas, para se rerem lirres d'estes corpulentos salteadores que lhes causam medo, cobrem-os com uma camarla de propo-

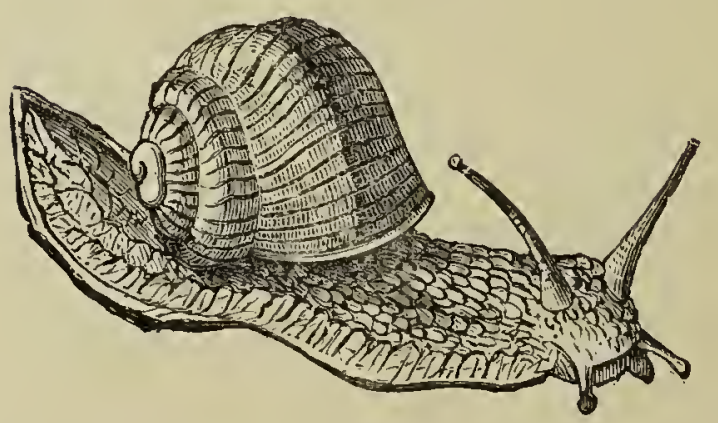

0 caracol lis, onde os sepultam. Mas os seus mais terriveis inimigos são os coleoptéros cantharidianos os Meloe pros- • caralurens e subretudo - Meloe variegalus, cujas larras rivem nas flòres, principalmente nas las leguminosas, e que se agarram com as fórtes garras e mandibulas ao ventre, articulações do thorax e cabeça das abellas. As abellıs, atacadas por estas larvas, fazem riolentos esforços para se lirrarem d'ellas, entram em convulsões e morrem irremediarelmente. 


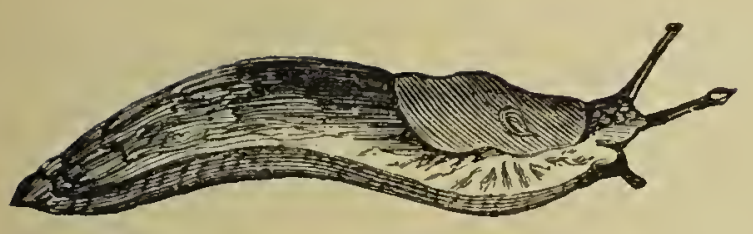

A lesma

Se chegam a alcançar a colmeia estão salras, pois as companlieiras correm logo en seu auxilio e desembaraçam-as das larras que as martyrisam, e que, muitas rezes chegam a ser mais de uma duzia.

A Philanta apirora (Phitiantus apivorus), uma respa de nove a dezeseis millimetrns de comprido, é tambem uma terricel destruidora das abelhas.

A Philanta apivora, como diz Brelım, é um insecto dotado de maus instinctos e $\mathrm{um}$ temirel salteador das abelhas. 0

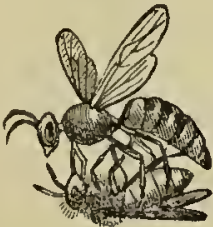

A Philanta apivora matanclo uma abella nome de lobo das abellacs, que lhe dĩo na Allemanha, provém de que lera, para alimentar cada nma das suas larras, quatro

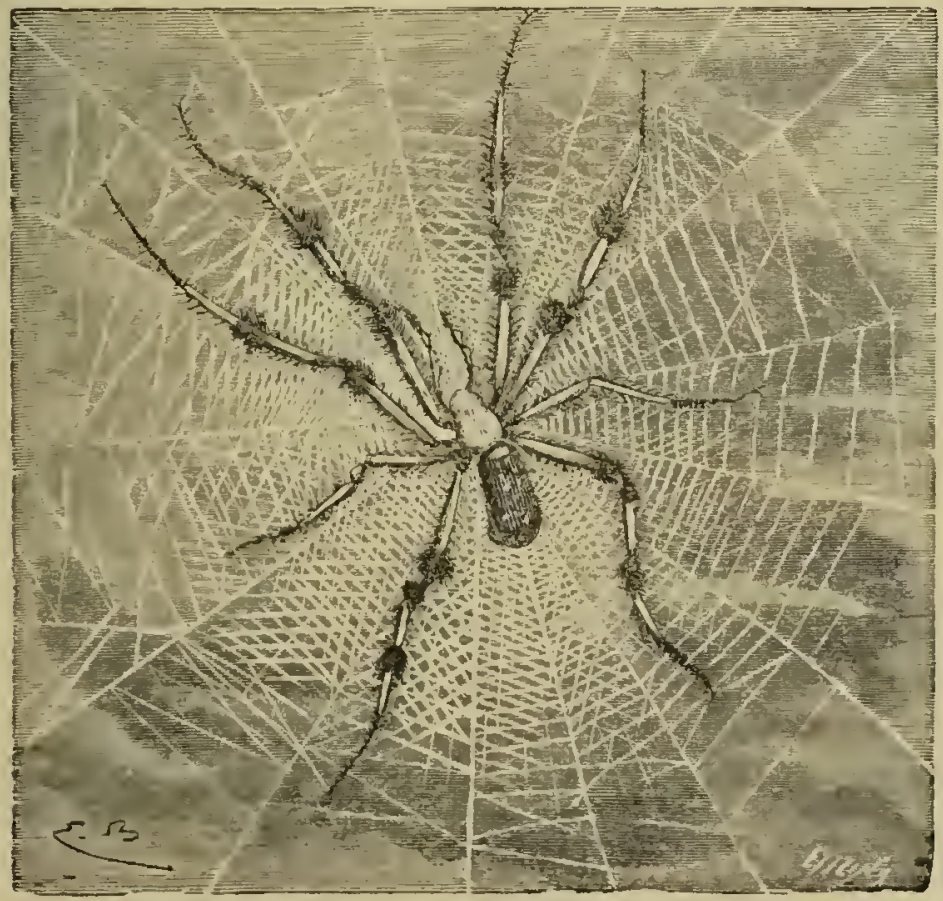

A arauha 


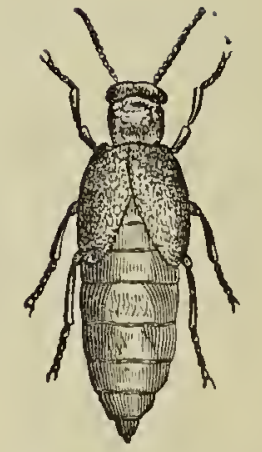

Meloe prosenrabaus fenca

a seis abelhas por dia. Audaz e revestida de uma fórte armadura, cahe do alto, como uma setta, sobre a presa, tomando-a de improviso, deitando-a por terra e paralysando-a antes que ella possa pensar em defender-se.

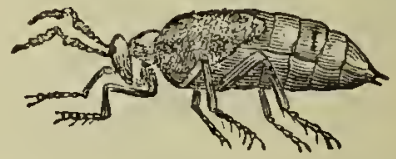

Weloe proscarabous macho

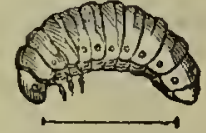

Larva do Meloe moscarabares

Depois de morta leva-a, atravez os ares, para o ninho.

o Clerus das abelhas Trichodes apiarius, esse lindo coleoptéro que mede doze millimetros de comprido, com os elitros de um vermelho vivo, atra-

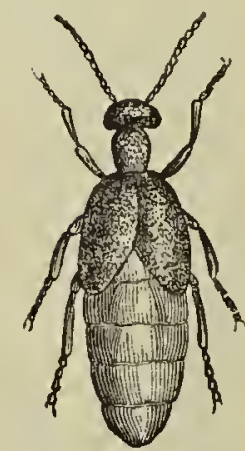

Meloe variegatus femea ressados por bandas azues, sustenta-se igualmente de abelhas.

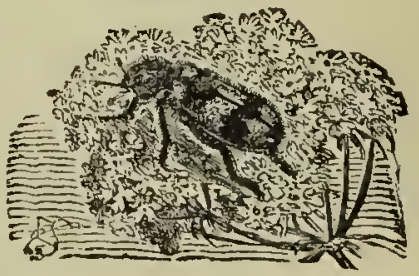

Clerus on Trichodes apiarius

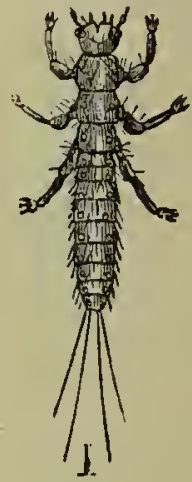

Larva do Meloe variegatus

Esconde-se proximo das colmeias, nas fendas que ellas apresentarem, ou nas das paredes e arrores proximas, d'onde sahe para caçar as abelhas que lhe ficam ao alcance, ou as que cahem com vertigem ou narcotisadas. Apparece de abril a agosto.

As abelhas possuem alguns parasitas dos quaes o mais curioso ó un diptéro sem azas e cego, o Braula cacca, que Pérez considera mais como um commensal do que como um 
inimigo das abelhas. Este diptéro, a que vulgarmente dão o nome de pulga das abellıas, só apparece nas colmeias fracas e velhas, e vire geralmente $10 \mathrm{~m}$ em cada abella, que não parece incommodar-se com elle. É visicel a otho nú; o corpo é escamoso, de um aver-

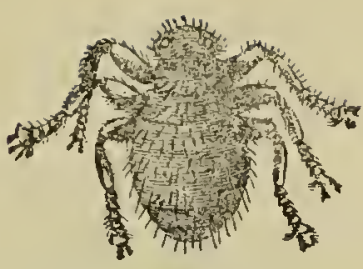

O Bricula crecre on pulga da abelha mcllado brilhante, e tem seis patas, com auxilio das quaes está fixo no corsclete da abelha. Quando a pulga quer comer dirige-se á bôca da abelha, onde, morendo

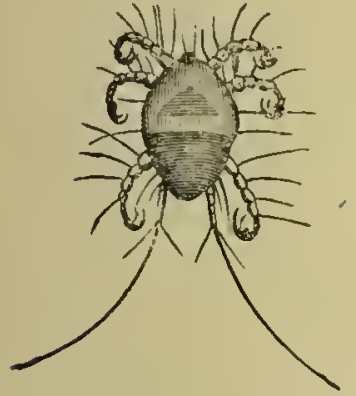

Trichodrectylus osmine rapidamente as patas, faz uma titilação desagradarel, que provoca a sahida de uma gotta de mel, que a pulga absorve de prompto, retirando depois noramente para 0 corselete.

Alguns acarianos como o Tirichoderylus osmiae vivem tambem no corpo das abelhas, scrindo-se d'ellas como meio de transporte para os locaes onde tomam a fórma sexual ainda hoje desconhecida.

Entre os rertebrados temos os lacertidios, principalmente os sarrlôes c as sardoniscas, as cobras, e os sapos, se beun que estes ultinos mereçam sel perdoados pelo diminuto mal que fazem as abellas, em virtude dos assignalados beneficios prestados á agrlicultura, devorando incessantemente millares re iusectos

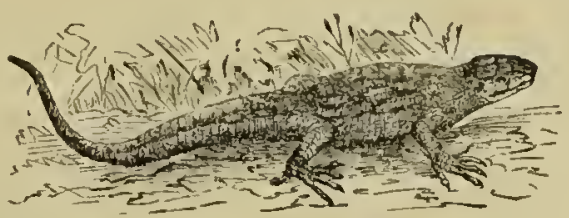

0 sardào

e rermes prejudiciaes; as santas aves insectiroras e principal-

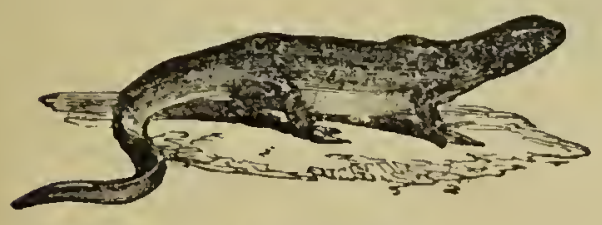

A sardonisca mente a util andorinha, que devora cada segundo milhares de pequeninos insectos, que seriam a destruição de todos os nossos regetaes, trabalham só de dia, mas, che- 
gada a noite, proeuram na fresea folhagem do enparlo arroredo um doee abrigo onde possam descançar das lides do dia,

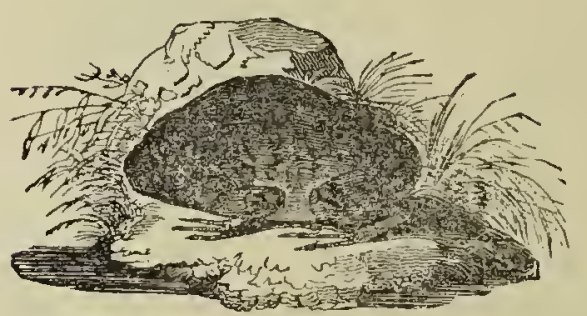

0 sapo e então noras nurens de inseetos, bando immenso de aniquilarlores infatigareis e potentes, reduziriam a nada o trabalio do homem sem o auxilio dos moreegos e do sapo, 0 moreego atravessanclo rertiginosamente os ares, limpa-ns de todos ns insectos que aeordan ao eseonder do sol, emquanto o sapo, neculto entre as herras das planicies, saerifiea sem remissão o molluseo e o inseeto que ousarem passar por junto delle. D'uma voracidade incrivel, necessita de enmer sempre e sempre, de estar eonstantemente com o estomagn repleto, n que redunda em benefieio do lavrarlor, pois de mais inimigos o livra, mais fruetos the conserva incolumes.

Por isso, se no seu mister de insectirnro, o sapo derora algumas abelhas, o prejuizo não deve ser grande, pois ellas de noite numea sahem da colmeia e este pouco eaça durante o dia.

Peor é o mal que lhes eausam os mammiferos e as ares. Dos primeiros temos entre nós os rariados ratos, o teixugn

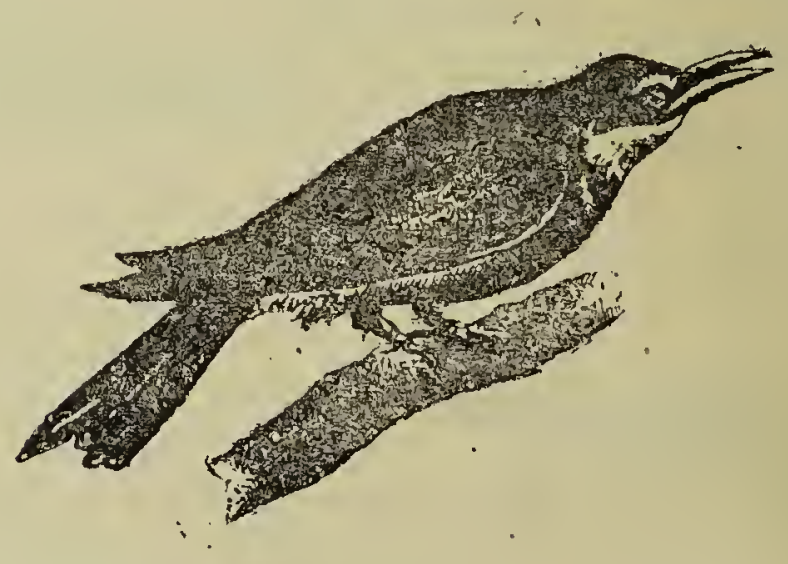

o abelharuco 
o ouriço cacheiro, a doninha, etc., e, entre as segundas, a immensa legiño d'ares que rae desde as andorinhas e petos até aos diminntos parus.

Ias entre todos avantaja-se o melliameo ou abelhameo, melro aiul ou murifella (Werops apiaster), commum no nosso paiz, e una das mais formosas ares da Europa. É approximadamente do tamanho de $\mathrm{nm}$ melro, com a parte anterior da cabeça rerde, a nuca e meio das azas castamho claro, costas amarellas com reflexos verles, garganta còr de ouro e negro, rentre e uropigio verde on azul, azas e cauda azul, verde e negro. Vive em pequenos bandos voando em constantes gritos. Sustenta-se de insectos, principalmente de respas e abellias que rem procurar junto das colmeias, devorando-as em abundancia até ficar completamente saciado.

O Purus major, quando esfomeado, pousa junto de uma colmeia, batendo fórtemente nas paredes externas d'ella com as azas e o bien. As abelhas sahem em tropel para castigar o ousado que as rem perturbar no sen trabalho honesto, e então elle, calindo sobre ellas, devorit-as coum sofreguidão.

Ein 1806 houre uma grande revolução no mundo das abelhas. Da America, transportados nas batatas, tinlam rindo os oros rlunia corpulenta borboleta nocturna a Splinx atropos, que, achando o clima da Europa favorarel ao seu desenrolvimento, se multiplicon d'im modo espantoso. Esta borboleta, cnja larra vire mas fulhas da batita, sem receio das fermalas das abellas, entrava mas colmeias, desperlacara os favos, e abarrotarit-se de mel, ahsorvendo em cada assalto approximadamente cincoenta gianmas. Houve entĩo, por un momento, grande panico entre os laboriosos insectos.

Como defenterem-se do inimigo, como evitar a sua entrada na colmeia? Como? Os apicultores dobalde cogitaram 110 meio de obstar á nova calanidacle e Huber, que mais que todos soffria com qualquer contratempo que prejudicasse as suas abelluas queridis, só se lembrou de pòr espessas grades de arame á entraida das colmeias, para obstarem á invasão do bandido. 
Mas se a Spluinx não podia cntrar na colmeia tambem o não podian fazer as abelhas com a precisa liberdade, e por isso, o remedio tcre de ser posto de parte como impraticarel. IIas as abelhas, d'um dia para outro, resolveram luminosamente - problema construindo muros de cêra de aberturas estreitas e tortuosas, cheios de arcadas e pequenas divisões em zig zacag,

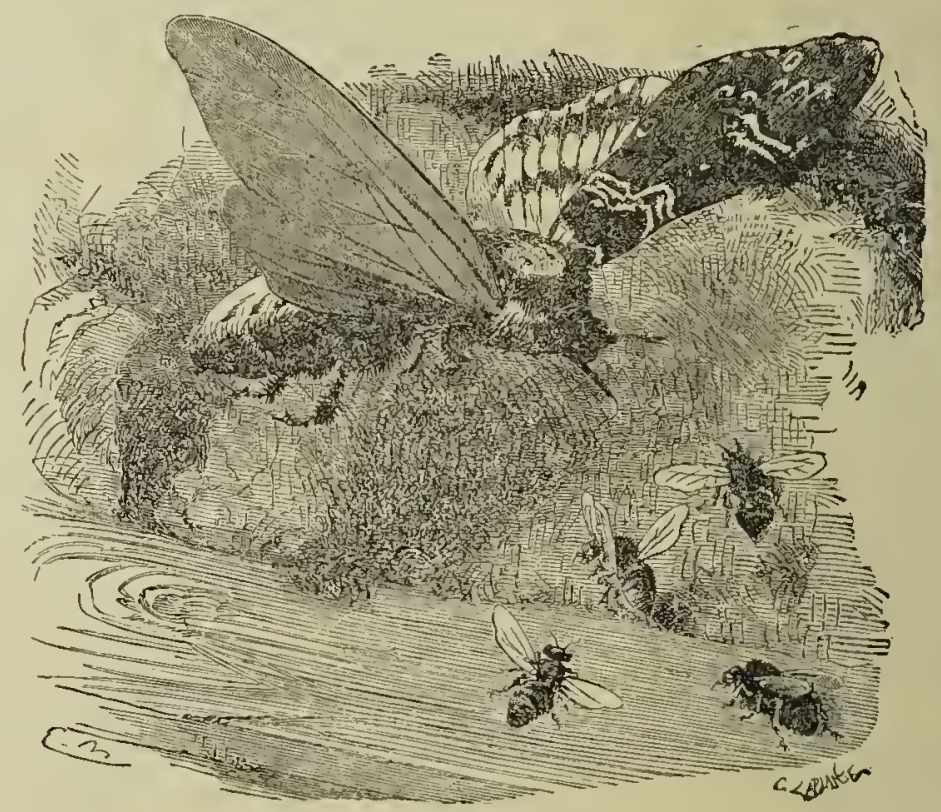

A Sphinx ou Acherontia atropos

por onde ellas facilmente entraram mas por onde o corpulento glutão não podia fazer passar o corpo.

Após este facto historico em que as abelhas, frente a frente com um caso noro, sem exemplo até então, o resolvem d'um modo tão satisfactorio, quem thes poderá negar a intelligencia crearlora, que raciocina, compara e escolhe?

As abelhas rehabilitam todos os animaes calummiados. Săo ellas que nos indicam o caminho a seguir, e que nos mostram que a felicidarle, o bem estar c a gloria, apenas ręsidem na liberdade e no trabalho. 


\section{0 fixismo e a antiga apicultura portugueza}

A apicultura prosperon em Portugal quando havia ainda extensos montados onde as abclhas encontraram farto e constante alimento e o homem lhes prestara bons e cuidadosos desroblos, grato pelo salutar e delicioso assucar fornecido pclos incansaveis insectos.

Eran então abundantissimas as colmeias por todo o paiz, sendo muito particularmentc protegida a sua dispersão pelos nossos primeiros monarchas, que, cm varios foraes, determinaram, entre largas medidas de proteção ás abellas, a paga annual pelos foreiros ao scnhorio, de un certo numero de mãos de ursos, os gulosos caçadores de colmeias que as procuraram part, depois de desfeitus, sc abarrotarem con mel por ellas contido, o que muito concorreu para a rapida extincção, no nosso paiz, do grande carniroro do rello continente.

Dos antigos concellos foi talvez o de Scrpa o que maior numero do colmeias possuiu outrola. O smr. José llaria da Graça Affreixo na sua Memoria historico-economica do concelloo de Serpa, diz que consta que, tenclo os moradores de Serpa representurlo a D. Diniz mostrando-the a grande riqueza que alviria para o concelho no estabelecimento de fabricas de cêra, o rei hics concedera para tal fim, por um foral, os maninhos da serra. nño sendo rlella permittidas roças nem fógos, por serem prejudiciaes ís flòres, e por consequencia, ás abelhas. 
Foram tambem determinados os limites dentro dos quaes só se poderia estabelecer uma malhadr ou conjuncto de dous estabclecimentos constituidos de uma cêrca, para resguardo das colmeias e casa para habitação do malliadeiro.

Estas malhadas eram de extraordinario rendimento, o que foi origem de continuas questões, pois os donos d'ellas consideraram-se senhores da serra, nâo deixando sequer que fosse lá pastar o gado, o que motivou em 1368 uma nora postura com o titulo de araniel das malladas, em que era determinado que cada malbada não puderia ter mais de quatrocentas colmeias, e em que se regulara a exploração da serra.

A descoberta da canna do assucar e a creação do celleiro commum em 1690, fez com que nos arredores de Serpa fossem pouco a pouco desapparecendo os grandes montados, substituidos por campos de trigo e ontros cereaes, e, portanto, diminuindo o numero de colmeias, que, comtudo, é ainda alli hoje importante.

Apesar da constante diminuição dos bravins e da grande abundancia de assucar extrahido de rarios regetaes e posto ao alcance do consumidor por um preço relativamente baratı. existem ainda numerosissimas colmeias por todo o Portugal, visto a larga importancia commercial do mel e da cèra qne teem sempre boa venda e preços vantajosos.

Mas, apesar da facil collocação do mel e da cèra, a apicultura, devido a um desleixo imperdoarel, tem-se conservado completamente estacionaria; cultivam-se ao presente as abellas entre nós como no tempo da fundação da monarchia. É o mesmo detestarel e acanhado cortiço, e as operaç̄os são as mesmas, o que faz com que a industria não tenla progredido como era de estimar, nem as colmeias de cortiça dêem o largo rendimento en mel e cêra que as colmeias moveis estão produzindo no estrangeiro.

Um rapido inquerito, por nós ultimamente feito no paiz, mostra-nos que por toda a parte se pratíca da mesma fórma. Cortiços de casca de sovereiro, ordinariamente de $0^{\mathrm{m}}, 55$ de alto e $0^{\mathrm{m}}, 30$ de diametro, dando, termo médio, meio litro de mel 
e um kilo de cêra. O mel ć extrahido en julho, operação a que sc dá o nome de crésta, destampanclo o abelheiro ou homem encarregado d'esse serviço, o cortiço e cortando os favos com uma cother de ferro chamada crestadeira, ou estimhorleira, até á altura de uma mão tracéssa, e deixando ficar o resto para sustento das abelhas. Os favos, depois de terem estado ao sol, oll serem expostos ao calor do fogo, são espremidos á mão, c o mel passado em se-

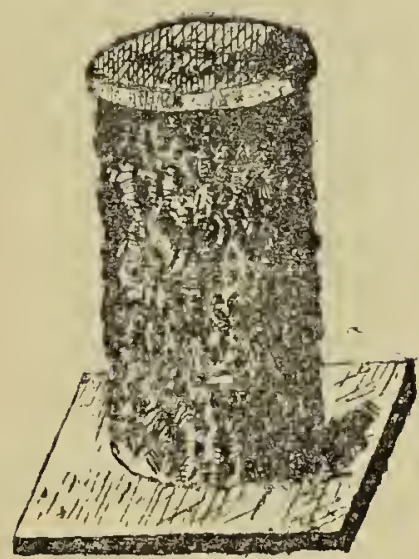

o velho cortiço guida pol um panno fino, $11 \mathrm{~m}$ cesto de vime, on uma meia, para o separar da cêra; esta é acabada de espremer em lagar de vara ou prensa.

Para evitar as aggressões das abelhas o operador envolve a cara en um panno com dous pequenas orificios no sitio dos olluns, panno a que dão o nome tapa rosto ou careta, e queima trapo á rolta do cortiço e por haixo d'elle, em quantidade tão cxtrardinaria, que fóma geralmente uma nuvem asphyxiante para elle e para as pobres abelhas.

O mel das créstas ó recolhido cm uma vasilha outrora de barro e hoje de folha de Flandres, chamarla anado, por ter duas azas e não uma só, como os cantaros e bilhas para agua. Estes azados, possuem duas azas ou pégas, por isso que sendo muito grandes e pesados, necessitam do esforço de dous lomens para serem erguidos e transportados.

De inwerno, ou quando ha unuita chuva, cobrem o cortiço conı $1 \mathrm{~m}$ alguidar voltado, uma carapuęa ou um coberto de palha ou un perlaço de lata.

E $n$ isto se cifra toda a sciencia apicola do lavrador luzitano!

Em Vinhaes e Bragança ainda substituem o cortiço de casca de sovereiro por cortiços feitos de troncos de castanheiro 


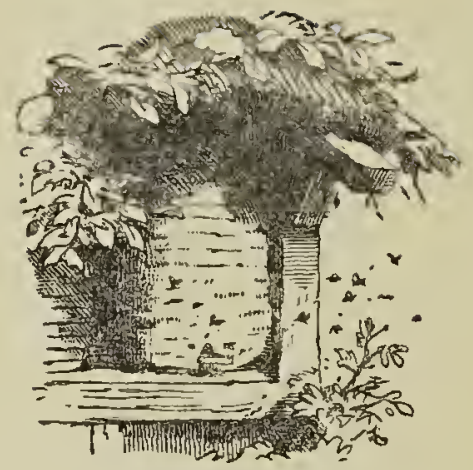

Cortiço sob abrigo de palha tornados ocos; são mais abrigados e as abelhas prosperam admiravelmente n'elles, 'sobretudo quando teem, como é frequente, $u m$ metro de alto e uns trinta centimetros de diametro.

No norte dão o nome de Silha ao colmeal cercado de paredes circulares, emquanto no sul chamam Silha a carla fila de assentos dos cortiços no colmeal.

Os colmenes são, em geral, dispostos em uma encosta, roltados para o nascente; quando completos, são cercados com altos muros de perira e uma casa de hospedarin e deposito de alfaias melliferas; não tendo casa de hosperlaria nem muros, chamam-lhe em alguns locaes malhadas, emquanto que em outros, como por exemplo em Serpa, dão o nome de mallarda ao colmeal inteiro.

A cultura mais usual e disseminada, porém, ó das colmeias isoladas, ou ás duas ou tres, junto das habitações, de qualquer parede, on mesmo pelos montes. As colmeias dos montes sâo, na primavera, trazidas para proximo dos campos, afim das abethas recolherem o nectar e o pollen das myriades de flôrsinhas que n'essa occasião os vestem. De longe, pelo caminho de ferro, quer na linha do Douro e Minho, quer na da Poroa, véem então ragonetes cheios de cortiços, que são espalhados pelos larradores da localidarle, que os consentem junto das propriedades, vigiando por elles mediante uma certa e determinada quantidade annual de mel por cada cortiço. Finda a colleita são noramente levados, por o mesmo processo, para os montes proximos.

No districto d'Evora, - segundo informações que nos deu o erudito escriptor Rev, Rocha Espanca, prior de S. Bartholomeu de Villa Viçosa, infelizmente já fallecido,_é a villa de Redondo a poroaşĩo que mais cultiva, ou explora, a apicultura, tendo cheios os seus colmeaes e ainda outros fóra do seu concelho, principalmente no de Alandroal. Alli ha ordinariamente seis a sete mil colmeias das quaes só umas mil e setecentas jazem dentro do concelho de Redondo. 
Estas eolmeias são crestadas pelo pé ou de sacada, è tirado todo o mel reunido pelos enxames, os quaes são batidos ou expulsos para outros eortiços, ás vezes dous ou tres para um só, que recebem então o nome de desabchos. Estes enxames morrem na maior parte á fome, eom o que pouco se ineommodam os seus randalicos exploradores, que dizem, que o mel e a eêra d'elles lhes dá para o enterro.

Portanto, depois da crésta em junlo, ficam só os enxames noros e alguns desabellos, e, por conseguinte, reduzido o uumero de eolmeias a metade, on menos de metade do que em antes da erésta.

A falta é porém remediada la seguinte fórma: No districto de Portalegre, principalmente em Assumar e Alegrete, seguem um proeesso eontrario ao de Redondo, cuidando mais na creação das abelhas do que na exploração dos seus produetos, ou porque a região se preste mais a isso ou porque a ereação lhes dê maior lucro. É alli que os eultiradores ou exploradores de Redondo, Extremoz, Borba e Villa Viçosa vão comprar colmeias a mil e dous mil reis cala una, afim de reporoarem os seus eolmeaes. Compram-as no mez de fercreiro para depois as matarem em junho.

No norte, a loealidade onde existe maior numero de abelhas, é no coneelho de Ribeira da Pena, região exeessiramente mellifera. Ha alli numerosos agrieultores que possuem mais de mil cortiços eada um, muitos seiseentos, e, no geral, de eineoenta para eima.

No eoneelho de Penella, diz-nos o eommendador Delfim de Oliveira, houve grande quantidade de eolmeias, mas hoje sĩo raras, se exeeptuarmos a treguezia do Espinhal. Os habitantes da serra, esses é que possuem ainda nunitas colmeias, e fazem uso do nel, espeeialmente no tratamento de toda a qualidade de doenças, tanto de pessoas eomo de animaes.

Em Felgueiras, eoncelho do Moneorvo, além do grande eommereio de eolmeias, existem tamben mais de trinta cerieiros ou meleiros, que vircm unica e exelusisamente de comprar pelas aldeias os faros com mel oll sem elle, e o mel a a cèra, que depois rão vender nas differentes terras dos districtos de 
Bragança e Villa Real, pois fazem as feiras de Mirandella, Chaves, Macedo, Bragança, etc.

É deveras interessante examinar os seus lagares da cêra, os seus instrumentos, calão, usos, etc.

A tirar a traça ou tinha das colmeias chamam estimhar. Quando a colmeia tem excesso de zangãos ou machos, dizem que está machia e que é necessario temperal-a tirandolhe o excesso de habitantes inuteis.

Dão o nome de monte temporão ás flôres de queiró c urze que vestem os montes, e monte serodio ás flòres que apparecem no verão. Ás flôres do mez de setembro e outubro chamam branquinha.

A operação de tirar o mel dos cortiços é conhecida pcla designação de cresta; quaudo o cortiço está clıeio de mel dizem que as abelhas melaram bem.

Os enxames primarios são enxamelhas, os secundarios garfas; as abelhas obreiras abelhas carreteiras, as mestras varejeiras e as larvas pulo.

O pulo é verde quando as larvas estão apenas nascidas e maduro quando as larvas estão a transformar-se en chrysalidas.

Ao pollen que as abelhas trazem nas patas chamam calças ou barro.

O caminlıo seguido pelas abelhas sahindo do cortiço para a labuta diaria tem o nome de carreira. O logar onde o cortiço está assente é conlecido por alvado e as bordas inferiores do cortiço por boises. Voltar uma colmeia para examinar 0 conteúdo é borcal-a; clıanam á colmeia com abellıas agglomeradas em pinha á entrada, colmeia agadada.

Os alveolos dos favos são casas das abelhas e o alveolo da mestra casa de abelha nova. A postura da mãe é a operação de varejar o enxame.

As abelhas a apparelharem são as abelhas a reunirem para a sahida do enxame.

Uma colmeia fórte é uma colmeia real, uma colmeia fraca é uma garfada de abelhas ou uma colmeia fraqueira. 
Ao panno com que cobrem a cara, para evitar as picadas das abellias, chamam caretu ou caraça, ao trapo a arder com que as fumigam morrio, ao ferro com que arrancam os favos e tiram o tampo ao cortiço estinhadeira.

Em Monsão lia anmualmente, no mez de dezembro, una importante feira, conhecida por a feira do mel, onde apparece á venda enorme quantidade de mel, realisando-se raliosas transacçòes lla especialidade.

En Sobrarlo, localidade distante uns tres kilometros da estação de Vallongo, na linlia ferrea do Douro, realisa-se todos os annos, en agosto, na vespera e dia de S. Thiago, uma feira exclusivamente destinada á compra e venda de abellias.

Os cortiços, trazidos de meia duzia de legulas em redondo, sĩo dispostos em espaços de terreno, alugados para tal fim pelos proprietarios da localidade. Ha feiras onde teem apparecido dez mil cortiços com abelhas.

São alli expostos á renda não só os enxames do anno, mas tambem os enxames vellos e os enxabelhos, ou reunião de dous ou tres enxames fracos cm unl só cortiço.

Os preços varian de dous mil reis a seiscentos reis, confórme o valor e importancia de cada cortiço. Os cortiços, vendidos, com a bôca tapada com um pamno, são, á noite, transportados para longe á cabcęa de mullèes, em burros, ao hombro de homens, suspensos nas duas extremidades de uma vara, ou pelo caminho de ferro.

Da ligeirissima c descolorida resenha do que é a apicultura ao prescntc entre nós, claramente se deprchende a importancia que esta industria viria a ter se lhe introduzissem os modernos aperfciçoamentos, que fazem annualmente correr de cada colmeia rios de mel.

Para não ser feita de um salto a transição para as colmeias moreis - o unico methodo racional c que dá um resultado favoravel de mais de cincoenta por cento,-devem os lavradores mais rotineiros utilisar ao nrenos as colmeias fixas de palla, mais amplas que o abominarel cortiço, e que permittem evitar a sahida de enxames, augmentando, na epocha 
de produç̧ãu, um andar á casa, fornecendo assin ás abellıas espaço para exercerem á rolltade a sua actividade productora no momento da grande colheita.

Para nós os melhores typos de colmeias de palha são a colmeia rulgar construida de palha ou vime, com trinta e cinco a quarenta centimetros de diametro e sessenta ou setenta centimetros de alto, e a colmeia normanda, de calotte

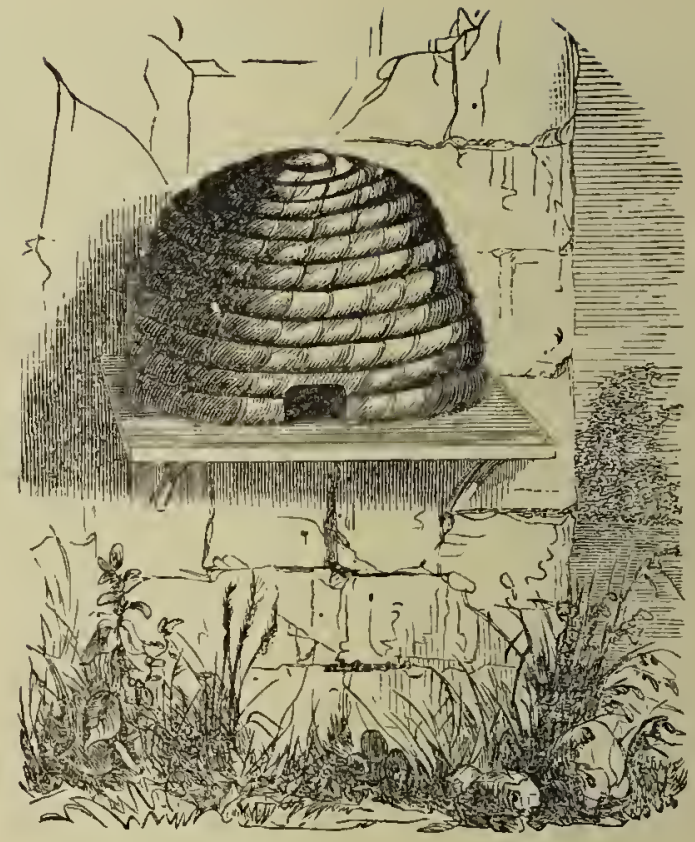

Colmeia vulgar de palha ou capacete, tendo trinta a trinta e cinco centimetros de diametro, por vinte e cinco a trinta e cinco de alto, e uma calotte ou capacete um pouco menor que o corpo da colmeia e de altura variavel.

A colmeia vulgar de palha tambem póde ter capacete como a normanda, capacete que então fica situado á altura indicada

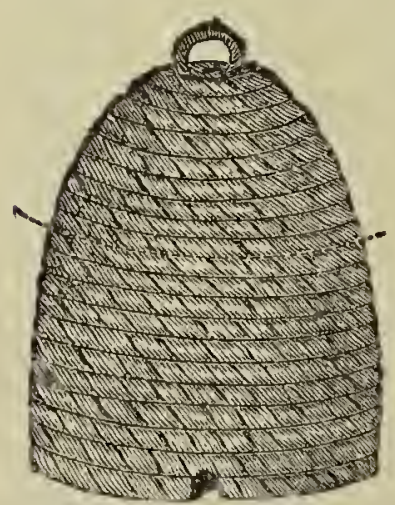

Colmeia valgar de palha, com capacete na nossa gravura por um leve pontuado. N'esse sitio a colmeia é tambem coberta com o tecido de palla, tendo apenas ao centro um pequeno orificio por oude depois as abelhas passam para o capacete. Em logar: do capacete póde-se collocar sobre a colmeia de palha uma alça com dezoito secções. Esta alça é inferiormente coberta de madeira, apenas com um orificio ao centro, que coincide com o do centro da colmeia, e superiormente coberta com tampa de madeira. 
Quer no corpo principal das colmeias de palha, quer nos capacetes, atravessam-se finas varas de madeira, como nos cortiços usuaes, para sustento dos faros; póde-se mesmo guiar o

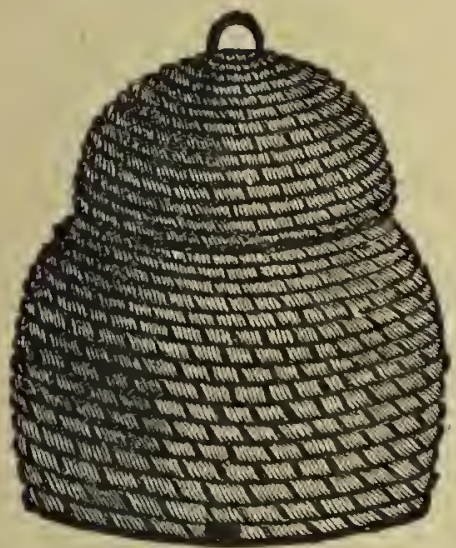

Colmeia normanda de calotte on calracete trabalho das abelhas por meio de pequenas tiras de cêra moldada, que se dispõem no sitio d'onde se pretende que comecen os favos e na disposição requerida.

To nosso relho cortiço tambem podia haver largo aperfeiçoamento, transformando-o com pouco custo e despeza. Para isto bastava fabrical-o em tres corpos distinctos, superiormente tapados com cortiça ou fina lamina de madeira, e apenas com um pequeno orificio ao centro para passagem das abellas de um corpo para o outro. Dos lados estas divisões seriam fixadas umas ás outras por meio de arames, pregos on mesmo cavilhas de madeira. Na epocha de grande producção mellifera, poder-se-hia assinı augmentar facilmente um ou dous andares no cortiço confóme a necessidade, andares que se retirariam depois cheios de magnificos faros com mel.

Isto já seria um grrande progresso e uma boa aprendisngem, que tornaria muito mais facil o manejo das colmeias moreis, que, on breve tempo, hão-de fatalmente supplantar as colmeias fixas, como o estĩo fazendo em todos os paizes cultos do retho o noro mundo.

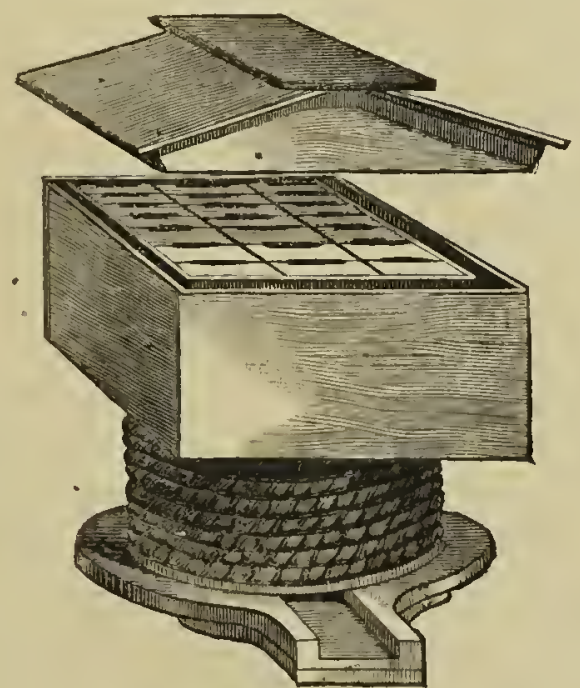

Culmeia de pallu com alģa 
As alças ou os capacetes das colmeias de palha, quer da vulgar, quer da normanda, derem entre nós ser postos en fins de narço ou principios de abril e retirados no fim de jullo. Verifica-se se o capacete está cheio de mel hatendo-llie com uma rara; se produzir som secco é porque está cleio, e se dér um som ôco é porque está vasio.

Então, em um dia de sol, das onze para o meio dia, que é quando as abelhas andam en maior numero fóra, descolla-se conı uma faca o capacete, geralmentc preso pelas abellias ao corpo da colmeia por meio do propolis, e tira-se com todo o cuiclado. Sc os favos do capacete estiverem presos á colmeia ć preciso tambem separal-os por meio da faca, e se ficarcm então defeituosos na parte inferior, levanta-se um pouco o capacete, tapa-se á rolta $\mathrm{com}$ unı panno e deixa-se ficar assim atć ao dia seguinte, pois, durante a tarde e a noite, as abellas aperfeiçoam e compõen a parte cortada.

Tirados os capacetes tapa-se logo com uma rolla, ou um pedaço de panno enrolado, o orificio central da colmeia e verifica-se se o capacetc traz a femea mãe, no caso de se não ter vedado o acesso d'ella ao capacete por meio da grade de zinco propria para tal fim.

Se ten a mestra, o que é muito raro, passam-se as abelhas, por meio do fumo e de pancadinhas, para outro capacete vasio, que se colloca sobre a colmeia, depois de se llue ter, já se vê, destapado o orificio central.

Ein ellas tendo passado para o corpo central, o que se realisa en poucas horas, tira-se outra rez o capacete vasio.

No caso do capacete não trazer rainha, ou se fazem immediatamente salrir d'elle as abelhas por meio do funo e das pancadinhas, ou se assenta sobre uma taboa, distante da colmeia, deixando-o levemente erguido de um dos lados, por onde as abelhas salıem em brevc tempo, depois de se terem enchido de mel.

É preciso, porém, vigiar estes capacetes, para os guardar logo que estiverem vasios de abelhas, e não os deixar estar 
sujeitos á pilhagem, que em poucas horas os limparia de todo o mel.

Os capacetes cheios de faros com mel, teem sempre prompta renda, a bom preço, e servem tambem para, no inverno, serem dados a colmeias fracas e sem provisões, o que muito as fortalece e torna aptas para, na primareri, enxamearem com força e produzirem uma abundantissima colheita. 


\section{O mobilismo-Descripç̃o \\ e modo de usal as principaes colmeias moveis}

Como é sabido os dous systemas de cultura das abellas, o fixismo e o mobilismo, baseam-se, um, em os favos estarem fixos á colmeia, e o outro, em permaneceren completamente separados, podendo ser d'ella tirados e tornados a collocar com a maior facilidade e sem o menor inconveniente.

Parece que já os antigos gregos usaram uma especie de colmeia de compartimentos moveis que, largamente modificada com o decorrer do tempo, nos deu as modernas maravilhas de industria que p̀ermittem seguir passo a passo o traballı da abelha, aperfeiçoal-o, tornal-o mais largamente productivo, e remediar de prompto as doenças ou os estragos causados por os insectos parasitas.

As colmeias moveis dividem-se em colmeias verticaes e colmeias horisontaes, que pódem ser de construç̧ão quente ou construceño fria.

Dá-se o nome de colmeias verticaes áquellas em que os quadros destinados á armazenagem do mel estão dispostos em alças, que se augmentam sobre o corpo da colmeia, e colmeias horisontaes quando se compõem apenas de um corpo alongado, com uma só fileira de quadros dispostos no sentido horisontal.

As colmeias horisontaes, a que servem de typo as colmeias Layens e Gayton, são mais simples que as verticaes, reclamam 
menos cuidados durante o anno e fazem menor despeza, visto não necessitarem de tanto material apicola como as colmeias verticaes chamadas de Gariel e Dadant Blatt.

As colmeias rerticaes precisam de mais cuidados ć rerdade, mas tambem produzem muitissimo mais e muito melhor mel, por isso que póden ser augmentadas á vontade, pondo-lhe um, dous e até tres andares, á medida das necessidades dos laboriosos insectos e segundo o seu modo natural de viver e produzir. São as colmeias de todo aquelle que se dedica de alma e coração á apicultura.

As colmeias rerticaes são, inquestionavelmente, as mais espalhadas de todas as colmeias.

São as rerticaes dos mil diversos systemas que os EstadosUnidos, a França, a Italia, a Allemanha, a Tuglaterra e a Suissa preferem.

Se a colmeia horisontal Layens é conhecida e tem sido ensaiada entre os apicultores enthusiastas, deve-o á larga e constante propaganda fcita por meio do livro, das revistas da especialidade e das conferencias, pelo seu sympathico inventor o francez Layens.

As colmeias verticaes, essas ó que não precisan de propagauda, pois teem de la muito a reputação feita em todo o mundo.

A colmeia lorisontal Layens, além de mais cara, mais trabalhosa de manusear, pois a introducęão dos quadros nos arancs, que ella possue, difficultam as operaçũes apicolas, é muito grande para o nosso paiz. E tauto isso está sendo recouhecido, que os poucos apicultores portuguezes que d'ella estão fazendo uso diridem-a internamente em duas colmeias distinctas, calla uma com o sell enxame. Ora isto é inconvenientissimo, pois póde acarretar decepçocs futuras, quando as mestras sahirem para serem fecundadas, e, cnganando-se na entrada, forem para a colmeia visinla, onde sĩo irremediarelmente nortas.

Uma colmeia cnorme, como ó a horisontal Layens, com un enxame só, esgota de prompto a inestra, em um paiz como 
o nosso, em que as abelhas quasi que não hibernam, pondo a mestra, pelo menos, dez mezes no anno.

Poderão ser boas em regiões frias, onde as mestras só pôem seis mezes quando nuito, mas não entre nós, onde a sua actividade é muito maior e mais constante.

Porque congressos, revistas e muitos auctores francezes e belgas teen aconselhado no centro da Europa a horisontal Layens de preferencia ás verticaes, não se segue que ella seja boa entre nós, com o nosso benigno clima e flora abundante, onde a abelha encontra colheita durante dez mezes do anno. Não é pois racional proclamar como magnifico para um paiz de clima temperado como o nosso, o que só póde dar bom resultado em regiões frias.

É como se, baseado no que se escreve em França e Belgica, fosse qualquer horticultor nosso dizer que a cansellia precisa em Portugal de abrigo de estufa para bem se desenvolver e florescer, e a laranjeira morre irremediarelmente se não fôr em setembro recollida em estufa onde tem de passar todo o inverno.

Defendendo as verticaes que achamos que são as que melhor se coadunam com o nosso meio, não proclamamos que ellas devem ter quadros pequenissimos, pois, como é ben sabido, as verticaes podem ter tambem, como as horisontaes, quadros grandes.

Teynac, $1 \mathrm{~m}$ verticalista, define perfeitamente isto da seguinte fórma:

"Os apieultores do norte querem o quadro mais alto que largo, por isso que, dizem, as abellas hibernam melhor no primeiro du que no mais largo, e os do meio dia mostram a sua preferencia por este ultimo, no qual, segundo elles, as abelhas hibernam tambem bem, offereeendo além d'isso outras grandes rantagens: $10^{\circ}$ para a postura da mãe; $2 .^{\circ}$ para a eolheita; $3 .^{\circ}$ para a verificação da enxamagem artifieial. Todo o mundo sabe que um quarto de tecto alto é mais quente de inverno que o de tecto baixo, d'onde se segrie que as colmeias que teem o teeto e os quadros altos são mais quentes no inverno que as outras; n'esta estaçăo as abelhas agrupam-se sempre no meio dos favos e alli formam cacho, deixando-os, se são muito largos, vasios de cada lado, 
Para a invernagem, alopto pois, eom o norte e paizes frios, o quadro mais alto que largo, e para a postura da mãe, e colheita do mel, com o meio dia e paizes quentes, o qualro baixo e largo.»

Segundo a sua ordem de idejas Teynac inventon uma colmeia remersable, isto $\hat{e}$ cujos quadros pórlem ser altos e baixos facultatiramente, altos para o inverno e baixos para o verão, colmeia que deridamente aperfeiçoada virá talvez a ser um dia a colmeia ideal, a colmeja perfeita por excellencia.

Eis como Teynac descreve a sua invenção:

"A diffienldade ern crear uma colmeia que podesse comportar facnltativamente quadros altos e baixos, o que consegui eom a minha colmeia renersable. Com ella, tudo é pois possivel e a apicultura tornar-se-ha uma das industrias mais lucrativas. Nào ha recoio de má inrernagem, nem de postura limitada por falta de logar solve min qualro muito estreito (porque, como é hem sabido, é em oval horisontal que sĩo postos os oros (las obreiras á sallicla to inverno); não ha colmeias em que as obreiras nào queiram subir ao logar de deposito de mel por eansa dos quarlros serem muito altos, nem quadros que se quebrem no extractor por isso qrie a

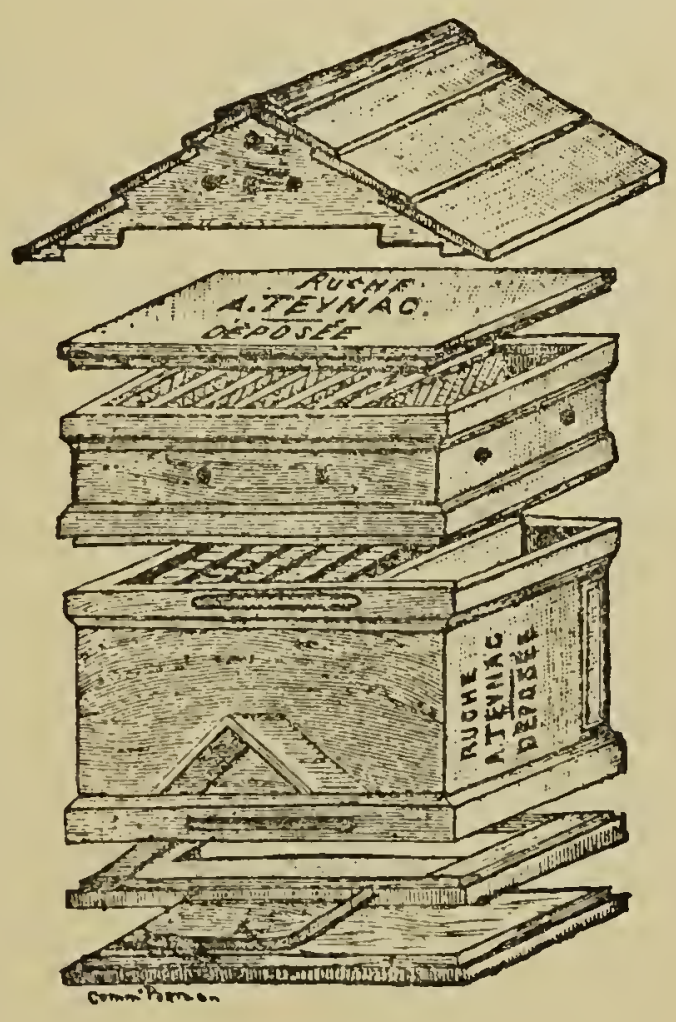

Colmeia Teynac colheita nĩo se faz senão nos pequenos. Tambem não se ví creação no deposito de mel, nem la diffiemhade para verificar a enxamagem das colmeias, que, por o nosso processo, fica quisi que por completo supprimicla, pois desejando-se póde-se evitar a postura de machos. Igualmente não ha neeessidade de zineo furato, nem pannos, o que augmenta o preço das 
eolmeias, nem de propolisação o que é $u$ m grande obstaeulo para a extraeção dos quadros.

Os do loeal destinado á postura pórlem ser tirarlos pela parte superior ou inferior do corpo da colmeia, sem neessidade de pinças, funecionando livremente entre os ganchos, e mudam-se de um lado para ontro, afin de dar liberdade ao que se quer tirar, disposição nora que permitte tiral-os a todos commodamente sem matar as abella nem esmagar a ereaç̃̃o.

Este systema de eolmeia renversable é um grande progresso em apienltura, resolvendo o problema tão diffieil, para o qual surgiram tantas diffieuldarles, apesar de ser na sua simplieidade o mais preeioso e o mais aperfeiçoado d'este ramo industrial.

Esta colmeia realisando os desejos de todos os apienltores de França, da Europa e da propria Ameriea, revolucionará o mundo dos mobilistas e mesmo dos fixistas, que aproveitarăo para o sen systema as vantagens que d'este porlerem aproveitar.

Em resumo: Os quadros da eolmeia rencersable são altos e baixos facultativamente. Para o inverno são altos e para o rerão baixos; disposições estas que farorecem de uma fórma muito rantajosa: $1 .^{\circ}$ a invernagem; $2 .^{\circ}$ a postura da mãe; $3 .^{\circ}$ a subida das obreiras ao deposito de mel, condição esta essencial para a eolheita. de muito mel.

Além d'isto esta enlmeia póde, á rontarle dos apieultores, angmentar ou diminuir, servir de colmeia dupla, ser roltada e supprimir a postura dos machos sem o eoneurso do zineo furado nem o da cêra moldada. Os quadros moveis, são impropolisaveis, e de um funccionamento extremamente facil; a eolneia é de construcção alta on baixa, quente, exeessivamente quente, ou fria, á vontade. A eonstrucção é solidanente feita e de hoa madeira de pinho; convem para eollier mel em seeções e para o extractor; serve indistinctamente para os colmeaes eobertos ou ao ar livre, assim como aos paizes de longa ou enrta producçĩo mellifera.

Para o inverno é igual á eolmeia Layens, e para o verão á de Dadant Blatt, porlendo funccionar eomo qualquer d'ellas. Tem doze grandes quadros de $42 \times 265$ no loeal da postura e onze pequenos de $42 \times 13$ no deposito de mel.»

Ató a colmeia Teynac ser a colmeia unirersal, cono nós os portuguezes perteneemos a um paiz temperido, o quadro baixo e largo é a que melhor nos convém, eomo ó o que meIhor convóm á Hespanlıa, á Italia e ao meio dia da França.

São verticalistas todos os grandes apicultores americanos desde Quinby e Langstroth, o creador da apicultura mobilista 
americana, até o celebre Root; sĩo verticalistas os apicultores de Italia, oncle é vulgarissima a colmeia Sartori, crjo quadro méde vinte e quatro centimetros de comprido por dezenore de alto; são verticalistas os apicnltores inglezes como Cowan, Sandringham e Bebbington; cstá espalhadissima na Suissa uma rertical, a colmeia suissa-colmeia Berlepsch, morlificada por Jeker-; são rerticalistas Darlant Blatt, Bertrand, Hamet, Damonneville, para citarmos só os principaes.

Que as colmeias horisontaes tcem muitos defeitos, sobretudo para os paizes como o nosso, dizem-o numerosos escriptores illustres na especialidade.

Citiremos ao acaso.

Bertrand na sua Conduite du rucher escreve:

«O typo Dadant (vertical) convém sobretudo ao industrial e no que pretende a qualidade ao mesmo tempo que a quantidade do producto, o typo Layeus (horisontal) ao cultivador para quem as abolhas sào uma condiẹ̃o aecessoria... Nos Estados-Unidos e em Inglaterra, paizes de grande producẹao, o typo rertical de tecto movel é o unico em uso; como alli o tempo é dinherro, o apicultor tem de fazer o trabalho $n$ menor tempo possivel, e preeisa de estar seguro de poder utilisar-se de torlo o mel que uma estaç̃̃o particularmente propicia, põe de tempos a tempos á sua disposição.»

Cowan é mais claro. Diz elle no seu Bee-lieeper's guide book:

"A pratica parece indicar que os quadros devem ser baixos om relaçio an sen comprimento, por isso que, com os quadros altos, é impossivel manter todos os quadros exactamente verticaes, sem a ajula le arames on outra qualquer disposição na base dos quadros; toclo o apicultor pratico verificarí facilmente que estes acerescentos, ben une perfeitos cm theoria, prejulican o deslocamento lateral dos quatros e póden ser a cansia do esmagamento de muitas abelhas ou da rainlia.

As colmeias baixas não tem necossidade d'isso. Os quadros baixos o compritos sino mais faceis de manejar, e sobretudo proprios para seren introduzidus 110 extractor, por isso que o faro é mais perfeitamonte acakarlo até haixo do que uns quadros altos.

Os espaços rasios, que se encontran nos latos dos quadros, permittem que 0 ar frio entre pelis extremidades dos quadros, assim 
como por baixo; ora, nos quadros-altos e estreitos, isto tende a estorvar o desenvolvimento da creação, por isso qne esta não se estende tão facilmente de cima para baixo como lateralmente»

A opinião de Damonneville no seu Traté illustré d'apiculture rationelle, resumindo vinte e cinco annos de experiencia do auctor, é a seguinte:

"Os productos que se obteem da Layens, apesar de serem de boa qualidarle, devem geralmente ser reputados um ponco inferiores aos que se pódem obter nos armarens das colmeias verticass, em virtude da tendencia das mães em pôr nos faros snpplementares dos armazens lateraes, excitar as abelhas a alli depòren pollen e algumas vezes um mel inferior. Apesar de n'ellas se poder obter mel ein favos prestam-se menos a este genero de produccino do que as colmeias rerticacs, sendo portanto, ponco do agrado dos especialistas que teem inportante consumo d'este producto de luxo.

Para sermos sinceros, devemos acerescentar que o tirar e collocar os muadros nas colmeias horisontaes aprós a extraç̧ĩo do mel, reclama sérias precauesóes pura evitar as tentatiras de pilleagem.»

Émile Palice, importante apicultor e negociante de colmeias horisontaes e de colmeias rerticaes de Nenry-Pailloux, expõe, com claro conhecimento do assumpto, o motivo da sua preferencia pelas verticaes, dizendo entre outras coisas o seguinte:

"A grande mainria dos apicultores preferem as colmeias verticnes e eu sempre me enfileirei an sen lado, depois de ter feito sérias experiencias a tal respeito: estou longe comtudo de dizer mal das eolmeias horisontaes, que dão ignalmente bons resultarlos.

A eolmeia rertieal presta-se melhor que toda outra qualquer á cultura do mel em farn. Permitte fazer imma selecçãn de mel de earla flòr eom mais facilidade, e. graças ao emprego do caça-abellas, o mel é muito mais depressa extrahiclo do que nas eolmeias horisontaes. O mel obtilo nas colmeias rerticaes é incontestarelmente superior ao que se recolhe com as colmeias horisontaes, sobretulo se se opera sem precauções.»

As colmeias chamam-se de construcę̃̃o fitia quando os quadros seguem uma direção perpendicular ao orificio da entrada, e de construç̧ão quente quando são parallelos ao mesmo orificio. 
Apesar de muitos apicultores celebres preconisarem as colmeias com os quadros parallelos á abertura da saliida da colmeia, o que dizem conserva muito mais calor dentro d'ella, somos apologistas decididos das colmeias de construcção fria, que consideramos as mais proprias para o nosso paiz, em que la no inverno a temer mais a humidade do que o frio, e que, portanto, necessitam uma boa ventilação, que os quadros perpendiculares ao orificio da entrada completamente facilitam.

Demais é esta a disposição que as abelhas dão sempre aos faros, quando inteiramente entregues a si proprias, e rariados factos historicos proram que ellas receian muito mais a falta de ventilação do que o excesso d'ella.

Layens conta que em uma floresta do Dauphiné, um enxame se installou ua parte superior da chaminé de uma casa abindonadib, onde viren perfeitamente durante muitos annos, fazendo crearão e augmentando os faros sem receio da fórte corrente d'ar que constantemente atraressara os faros, e da neve e chuva que lhes cahia em cima.

Derosne narra que existe em Aranne, perto de Besançon, nm enxame que desde $186 t$ está installado entre os vidros e a portada de uma janella, onde tem soberbos favos de mais de sessenta e cinco centimetros de comprido cada $1 \mathrm{~m}$.

D'aqui se ví o quanto é indispensavel a boa rentilação das colmeias, largamente farorecida pela disposição perpendicular dos quadros ao orificio da entrada, que constitue o trpo das colmeias frias.

São de construcção fria as colmeias rerticaes Gariel, Dadant Blatt, Sequeira, Cowan, Langstrotl e a liorisuntal Layens, c de construccĩo quente a horisontal Gayton.

E. extraordinariamente largo o numero de typos de colmeias conhecilis ato presente. Cada apicultor tem uma, differente apenas de qualquer dos plincipaes typos consagrados por pequenas modificaçôs que a tornam mais adaptavel ato meio onde tem de existir.

Deixando porém essas variantes proprias só de um longo 
estudo especial, vamos descrever as principaes colmeias universalmente adoptadas com proveitoso resultado, e que nos parecem dever interessar mais rantajosamente ao apicultor portugnez.

A colmeia Gariel, a Dadant Blatt e a colmeia que o nosso amigo e digno director da Companhia Horticolo-agricola, snr. Jeronymo Nonteiro da Costa, lançou no commercio, e que é uma feliz modificação da Gariel, tornando-a mais adaptavel ao nosso meio, e que amavelmente baptisou com o nosso obscuro nome, pelo que, aqui, penhoradamente the tributamos os nossos sinceros agradecimentos, são as que apresentamos como modelo, e muito proprias para um paiz mellifero como o nosso, onde as abelhas cncontram pasto pelos campos durante quasi todo 0 anno.

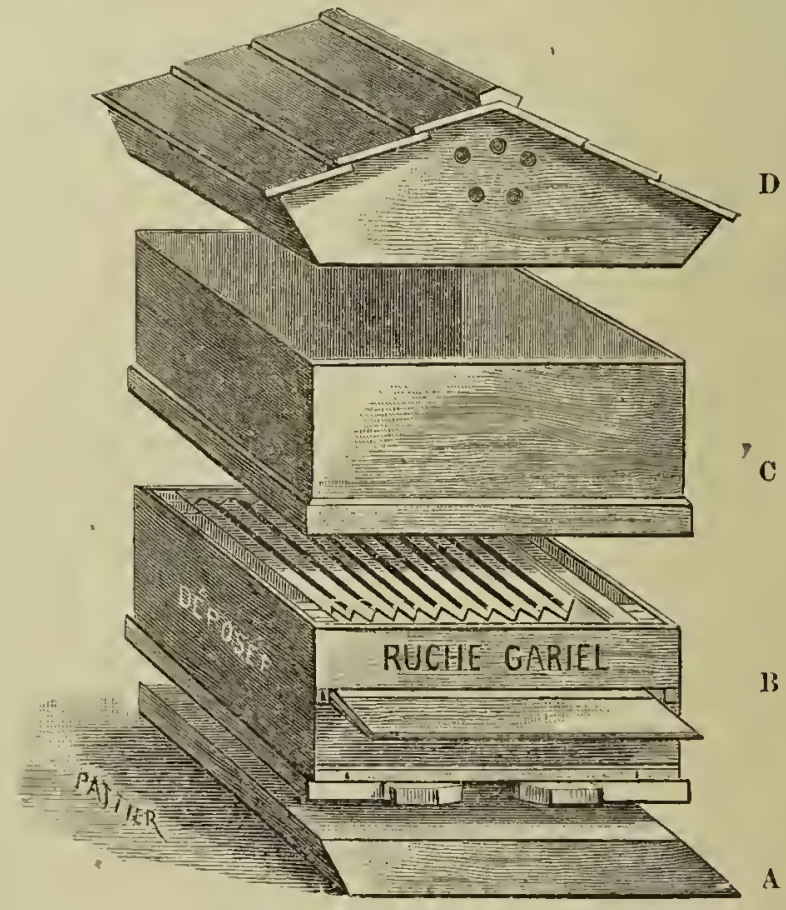

Colmeia Gariel

A colmeia Gariel e a sua modificação Sequeira, compõem-se do quatro partes: a primeira, a começar pela parte 
inferior, é a basc (A), ou supporte de madeira, apresentando na frente um plano levemente inclinado, que dá facil accesso ás abellas, e onde ellas muitas vezes repousam antes de entrarem na liabitação, c, na parte posterior opposta á cntrada, um pequeno alçapão com fina rède de metal e porta de madeira, que serve para, na força do rerão, ventilar a colmeia, fazcndo circular atravez os quadros'um ar: puro e bom.

Isto é importante, pois as abelhas tendo a casa bem ventilarla c fresca, occupam-se todas na colheita, emquanto quc, no caso contrario, uma parte tem de ficar empregada, por meio de um constante bater d'azas, cm fazer a renovação precisa do ar, diminuindo assim espantosamcute a quantidade de mel c pollen collido.

A segunda partc da colmeia (B) é o compartimento destinado á creação.

Consiste em um cubo que assenta sobrc o supporte, tendo na frente um córte por onde entram as abelhas, abertura esta que póde ser extrcmamente diminuida ou augmentada á voutade por meio de corrediças de madeira; superiormente a ella existe uma pequena taboa inclinada que protege a entrada do ardor do sol e da riolencia da chura.

Qucr na frente, do lado por onde entram as abelhas, quer na parte posterior, existem internamente uns vasios cobertos com una tira movel de madeira, que servem para, no invcrno, screm clıcios com serradura de madeira, palha triturada, lã, ou qualqucr substancia que torne mais quente a colmeia. Na scparação interna posterior existcu dous vidros, que correspondem a duas portadas da parte externa da mesma parede do compartimento, e quc servem para se examinar o traballıo das abellıas sem as incommodar de fórma alguma.

E na parte superior dos vasios que correm duas reguas onde são suspensos os quadros.

A colmeia Gariel lera quatorze quadros cmquanto a colnieia Sequeira comporta só dcz.

A terceira parte (C) compùe-se do andar destinado a deposito de mel. É un cubo que comporta uma alça especial 
que póde levar o mesmo numero de quadros que o da creação, ou pequenas secçĩes especiaes.

Por ultimo a quarta parte (D) consiste no tecto, composto de pequenas taboas inclinadas enl fórma de telhado, que dão facil e prompto escoadouro ás aguas da chuva.

Conlecidas as colmeias

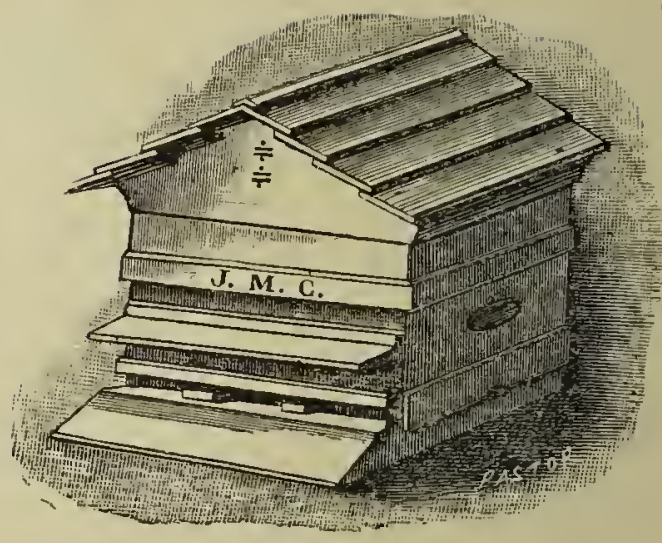

Colmeia Seqneira Gariel e Sequeira, passamos a explicar, da melhor fórma possivel, o modo como funceionam.

Assente no supporte o compartimento destinado á creação, fricciona-se-lhe leremente o interior com um pouco de mel, e dispõem-se n'elle os quadros que comportar, mas já com cêra moldada. É conveniente que a lamina de cêra moldada enclıa

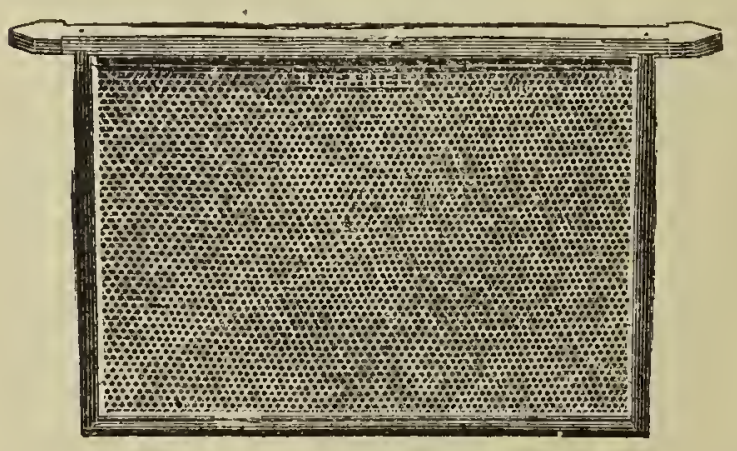

Quadro conı cềra moldada todo o quadro e não parte d'elle, como fazem alguns apicultores. Enchendo todo o quadio não só se obriga as abellıas a uma construcção perfeitamente regular, mas tambem se lhes facilita o serviço, fazendo com que a postura se não

demóre, seja maior e, portanto, a população se desenvolva perfeitamente e se tornc apta a angariar a precisa quantidade de mel para a primeira libernação. Como se sabe o diminuto tanranho dos cortiços usados entre nós não lhe consente grande população, de modo que as primeiras povoadoras das colmeias moveis, a não se reunirem dous enxames n'um, o que nem 
sempre convém, são em numero quasi se póde dizer insignificante, rclativamente á capacidade da colmeia.

A cèra moldada

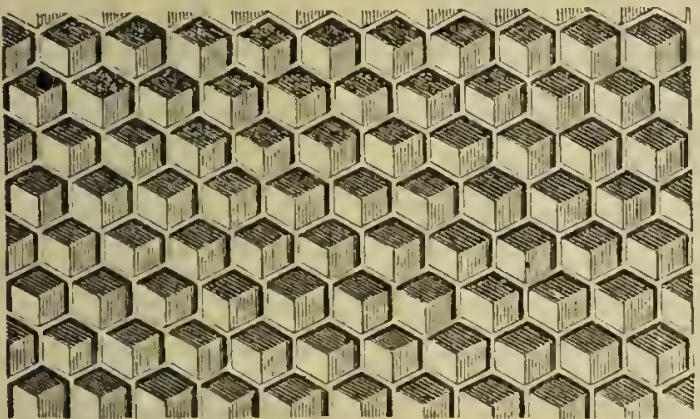

Cêra moldada que o apicultor póde preparar, como ensinaremos em capitulo especial, ou comprar nos negociantes da especialidade, consiste em laminas finissimas de cèra, tendo moldadas as bases das cellulas de obreiras ou machos, de modo que, confórme se lhe fornece um ou outro typo, se farorece en mais larga escala a postura de machos ou de obreiras.

A cèra córta-se promptamente do tamanho requerido, por meio de uma roda de metal cspecialmente destinada a este fim.

Querendo apenas fixar uma tira de cêra moldada en um quadro, córta-se esta do comprimento do quadro o da altura requerida, prendendo-a depois com uma tira de madeira na ranlura do quadro, como o mostra a nossa gravura.

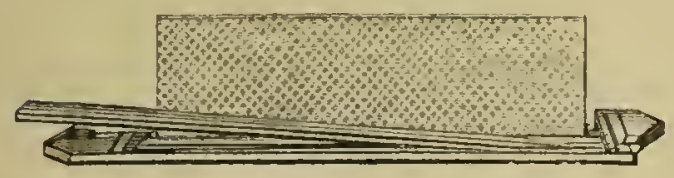

Hodo de fixar as tiras de cêra nos quadros

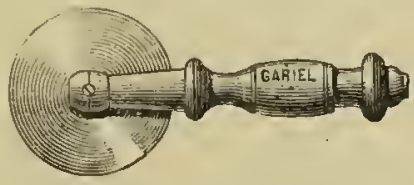

Roda yara cortar cềra molilada

Se porém se quer encher todo o quadro com cêra moldarla, cntão o processo é muito diverso.

Com o fixa-ganchos Paschoud prendem-se nos lados internos dos quadros pequenos ganchos de metal. Para inserir os ganchos na madeira introdu\%-se a parte curva d'elles na feuda da extremidade do apparelho Paschoud, encostam-se 
as pontas á madeira e carrega-se no cabo do instrumento, fazendo assim entrar o ganeho até á altura requerida. Depois

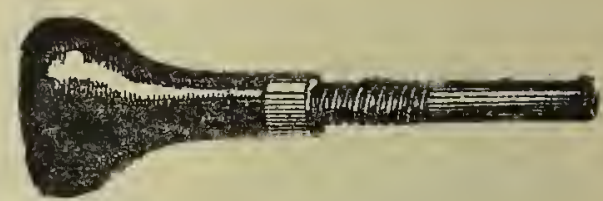

Fixa-ganchos Paschoul

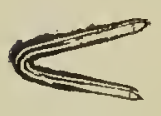

Ganchos

de introduzidos

os ganehos passa-se atrarez elles um fio de arame estanhado, muito fino, em dous ou tres crusamentos, de modo que fique solidamente preso e bem distendido, arame onde depois se insere a eêra moldada. Ao colloear a eêra no quadro é preeiso que ella fique sempre com dous, dos seis lados das eellulas, perpendieulares e numea horisontaes.

A eèra dispõe-se pousando-a nos fios de arame e eorrendo depois sobre ella, ao longo dos fios, a roda do esporão Woiblet, antieipadamente aquecido ao fogo

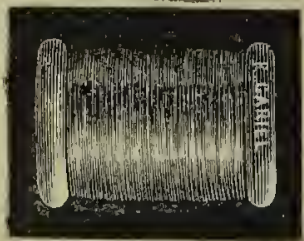

Novello de fio de arame estanhado ou mergulhado em agua a ferver.

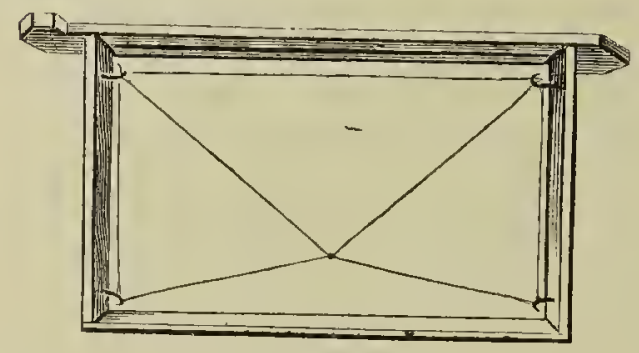

Qnadro com arame

Prompto o quadro eom cêra moldada dispõe-se na eolmeia da fórma que indieamos.

Se porém o enxame a introduzir fồ muito fraeo, ou a estação já estiver adiantada, é bom tornar então a eolmeia mais pequena por meio de quadros

de madeira, que se mettem dos lados, em rez de quadros com cêra moldada.

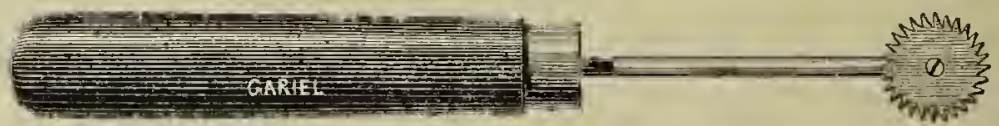

Esporão Woiblet 
Dispostos todos os quadros cobrem-se superiormente com un panno fino, de modo a redar por completo o aceesso das abelhas á parte superior da colmeia e aos pequenos compartimentos lateraes, destinados a eamara d'ar durante o rerão, e de aquecimento durante o inverno. Sobre este panno dispõe-se depois um feltro ou tapete, afin de manter a precisa

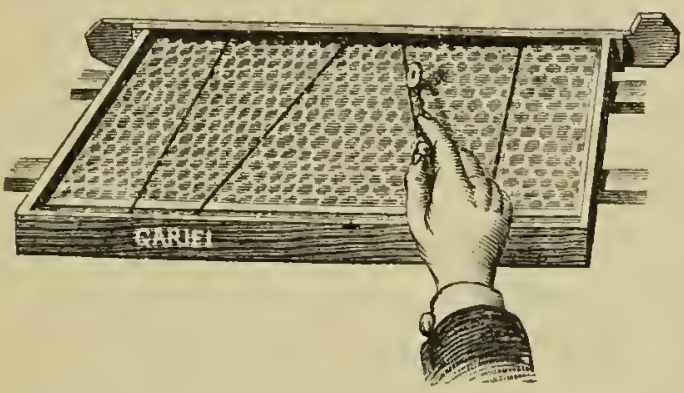

IIodo de empregar o esporão Woiblet para fixar a cèra nos arames

temperatura na colmeia. Durante o rerão póde deixar-se 0 panno e um feltro, ou até só o panno, mas no inverno é preeiso fortalecer os resguardos.

No primeiro anno em que as abelhas são introduzidas na eolmeia movel, nunca se the põe o andar com alça, pois ellas não teem possibilidade de o ir oeeupar, sendo-lhe todo o tempo preciso para construir as cellulas do eorpo principal da colmeia e tratar da ereação que ellas contiverem.
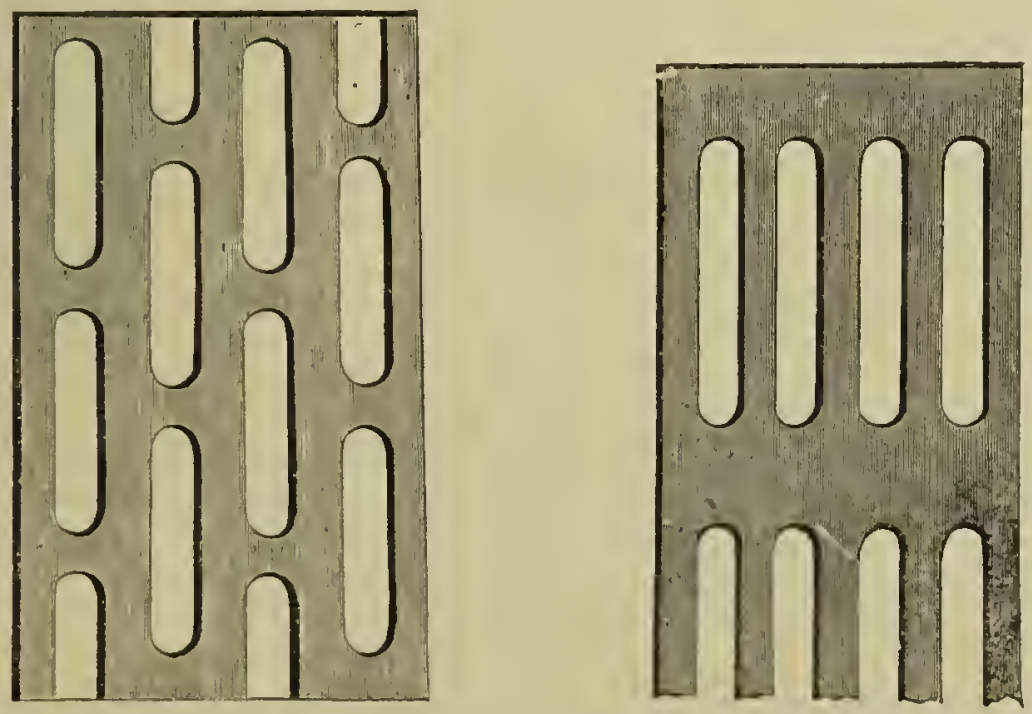

Zinco furado para deter as abclhas mestras e os machos 
No segundo anno porém, chegada a primavera, se a colmeia estiver fórte, póde entâo pồ-se-lhe o andar e a respectiva alça.

Como este andar é destinado só a armazenagem de mel, é conveniente vedar-the o accesso á mestra e aos machos; para isto, tira-se os pannos que cobren os quadros do primeiro compartimento, e, sobre elles, assenta-sc uma grade de zinco cujas aberturas são de um tamanho tal que só deixam passar atravez ellas as obrciras, que assim se cutregam á tarefa de construir alveolos e armazcnar cêra, sem serem incommodadas pelos zangãos nem a mestra ir lá depôr oros, transformando assim os faros destinados a mel em faros de creação.

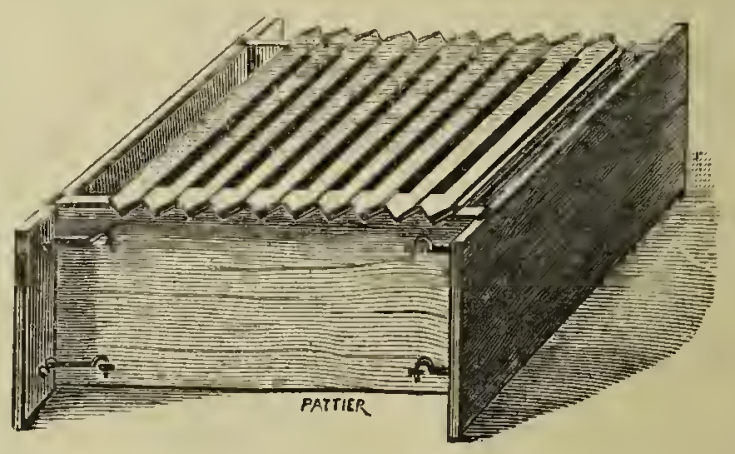

Alẹa com quadros

Pusto o zinco assenta-se sobre elle a alça, tapando depois os Jados externos com pannos, de fórma que as abellas não possam ir para os outros vasios da colmeia. Na alça pódem-se

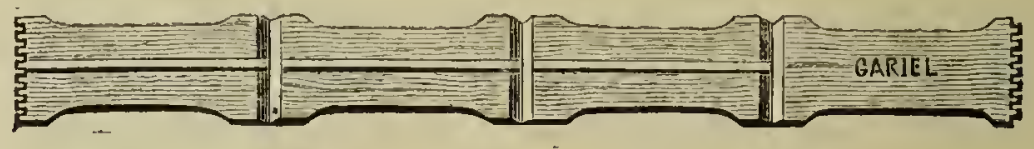

Serçào aberta

dispôr, ou um numero de quadros igual en quantidade e tamanho aos do primeiro compartimento da colmeia, e todos 
com cêra moldada, ou pequenas secções proprias para tal fim, e que dão depois uns faros de um seductor aspecto, muito

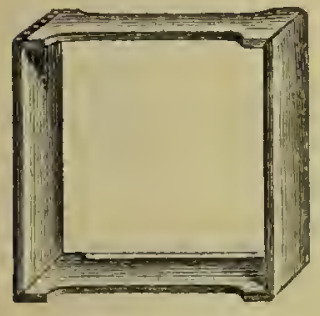

Seçęio fechada

e prompta a sel utilisada proprios para venda. Estas seç̄ones devem tambem ir já com cêra moldada, ou em todas ellas, fixa sem arame nas ranhuras internas que a seç̧ão possue, ou só uma pequena tira presa en uma das ranhuras. Para isto utilisa-se o fixador Parker que, prompta e facilmente prende com solidez as referidas laminas de cêra. Estas secçôes enfileiram-se em alça propria, em fórma de gaveta como a alça Benthall ou em

caixa como a Gariel. Estas secções são separadas umas das outras por pequenas divisões moveis de madeira muito fina, indispensareis para eritar que as abelhas prendam os favos uns aos outros, tornando-os assin defeituosos.

As seções tambem pódem ser collocadas no corpo principal da colmeia ou mesmo na alça usual, dispostas ás seis cm cada

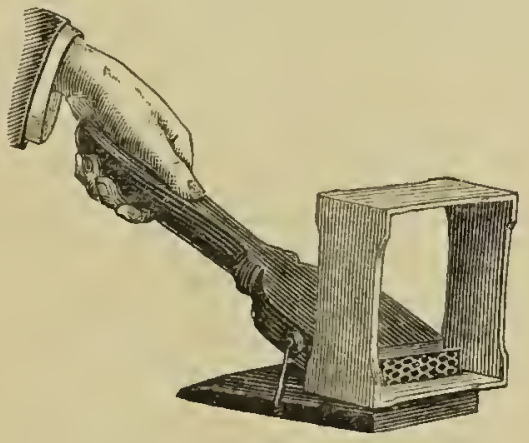

Fixação das peq̨uenas tiras de cêra nas secções quadro; mas, para isso, o preciso separar os quadros das secçũes dos quadros da creação, por meio da dirisão rertical

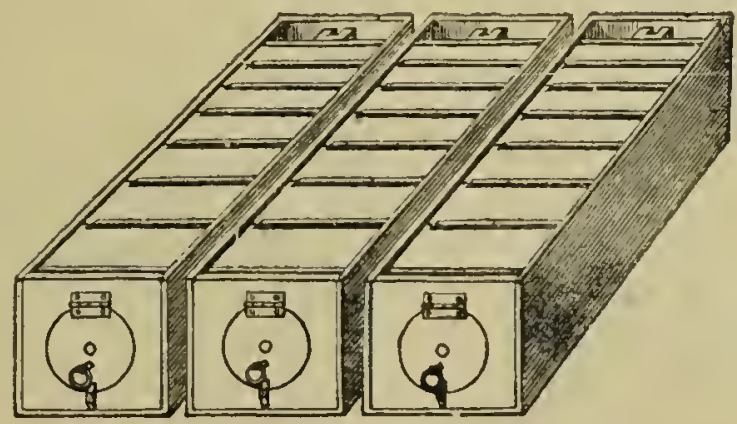

Alça Benthall para seçòes 
de madeira e zineo furado, afim de excluir das seeções os machos e a mestra.

A alça, depois de preparada e disposti, cobre-se com um

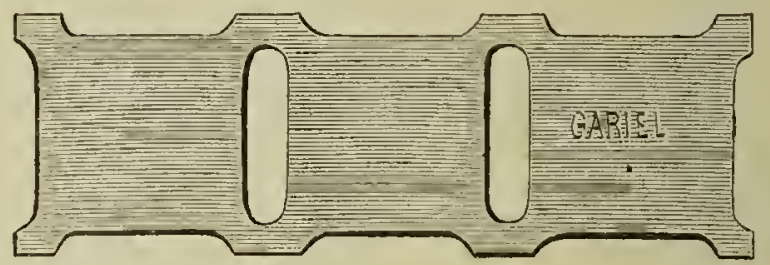

Separaçàno de ties seccūes

panno fino e um feltro, exactamente como se faz no eompartimento principal, antes de ter alça, afim das abellas ficarem

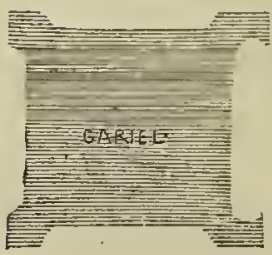

Separaçũo de uma só seecão

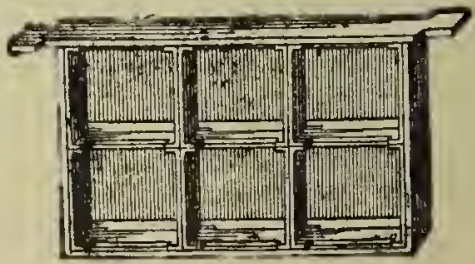

Quadro eom seeçòes

no espaço que lhes é destinado e não poderem passar para o teeto da eolmeia.

A colmeia não deve ser assente no sólo. Convém que fique um poueo alta, não nuito, em pés de ferro, ou em pedestal de madeira, semelhante ao indicado pela nossa gravura, que é muito eommodo, pois póde ser aberto e feehado com toda a promptidão, sen-

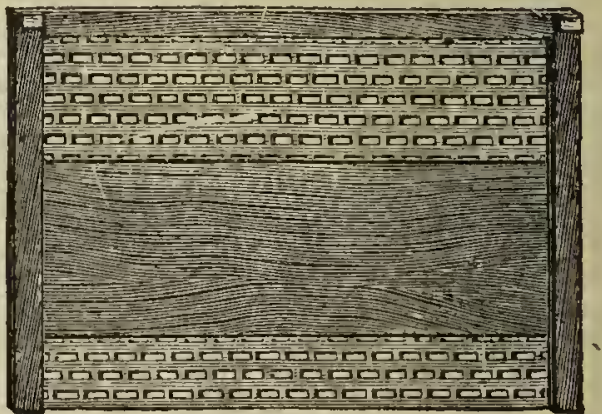

Separação vertical 


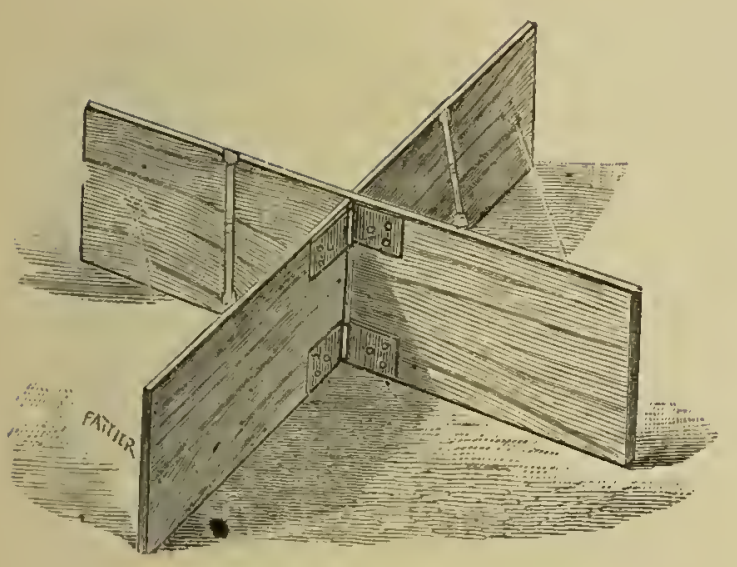

Pedestal de madeira para colmeia

do assim facil o seu transporte e mudança. Convém a cada apicultor ter só $11 m$ systema de colmeia, para servirem, indistinctanente em torlas, os mesmos quadros, compartimentos, alças, etc.

A colmeia vertical Cowan consiste em uma caixa feita de madcira de uma pollegada de espessura, podendo conter dez a treze quadros, typo da Associação, isto 6 com quator\%e pollegadas de largura por oito e meio de alto ( 35 a $56^{\mathrm{cm} .} \times 21$ a $49 \mathrm{~cm}$.); a travessa supcrior dos quadros tem tres oitaros de pollegada de espessura, a inferior 1 m oitaro e as dos liclos um quarto. A largura do quadro ó de sete oitaros de pollegada. Estes quadros entram em uma caixa de quator\%e pollegadas e meia $(36 \times 83 \mathrm{~cm})$ da parede dianteira á trazeira, e oito pollegadas c setc oitavos (22 a $5 t^{\mathrm{cm}}$ ) de altura. Os bordos interiores do alto das paredes da parte dianteira e trazeira sĩo entallados e guaruecidos de tiras de lata, sohre as quaes repousan as extremidades dos porta-favos.

Na base está a entraila para as abelhas. communicando com o ecntro dat colmedal nom lados e na parte silperior interma hat expacos que, de verĩo, selvem paral camara de ar e, no inrerno se enchem de substancias isolarloras que mantenham o

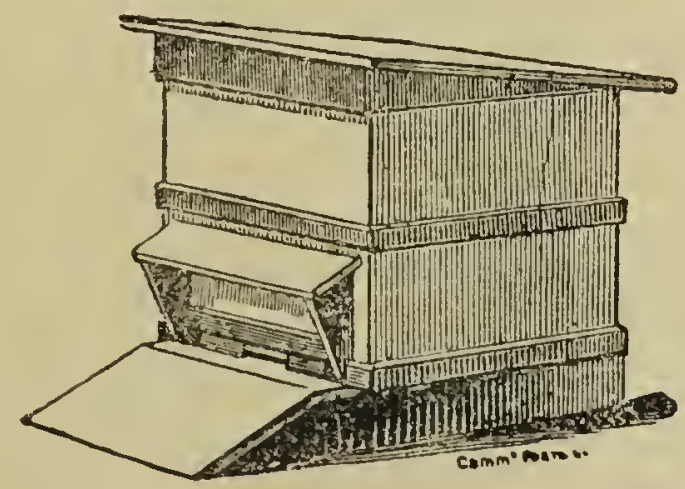

Colmeia Cowan 
preciso calor no interior da colmeia. O tecto ó $\mathrm{um}$ plano inclinado, deixando escorrer a agua da chuva para a parte posterior da colmeia.

A colmeia rertical Langstroth abre pela parte superior, tendo dentro os faros presos a quadros suspensos que não tocam nem no alto, nem no baixo, nem nos lados da caixa, deixando um espaço de oito millimetros para as abelhas poderem circular com toda a liberdade.

A colmeia Langstroth leva geralmente vinte qualros de

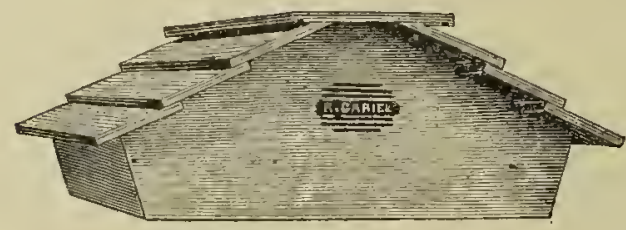
$215 \times 425$ millimetros, e tem a base fixa.

A colmeia Internacional ou de Dadant Blatt typo rertical e de construccão fria, ó uma modificação feitu por Dadant á colmeia de Langstroth simplificáda já por Quinhy.

É composta de $1 \mathrm{~m}$

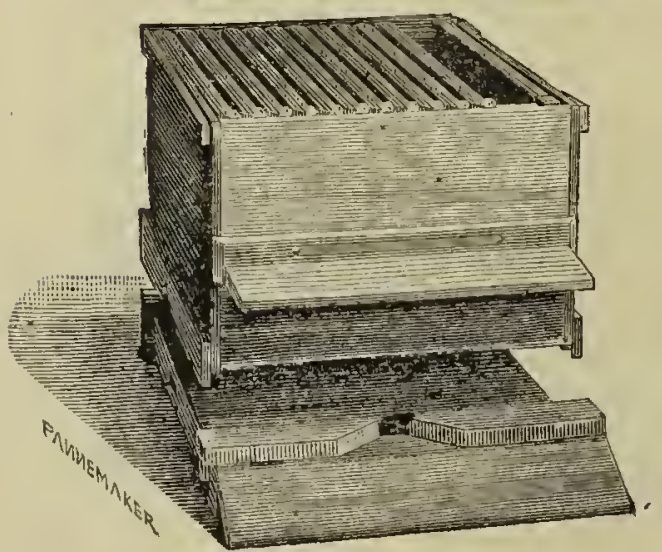
corpo principal constituido por quatro paredes, formaurlo um vasio interior com quatrocentos e cirlcoenta millimetros de comprido, quatrocentos e cincrenta de largura e trezentos e vinte de altura.

As paredes fronteiras e dianteiras teem, internamente, na parte supeColmeia Dadant Blatt rior, um encaixe de qua- 
torze millimetros e meio de alto sobre doze e meio de largo, no qual são suspensos doze quadros, que teem trezentos millimetros de alto e quatrocentos e trinta e cinco de comprido; são feitos de sarrafos de rinte e dous millimetros de liugrnra, e eompostos de cinco peças, quatro que formam o quadro e uma que serve de reforço na parte inferior.

Estes quadros são espaçados entre si trinta e sete millimetros e, para evitar que desloquem, assentam inferiormente em um arame disposto em fórma de dentes.

Para obrigar as abelhas a dar ao favo a espessura requerida préga-se en cada quadro, uos dous lados montantes, uma lamina muito fina, de madeira ou lata, de quatrocentos e trinta e dous millimetros de eomprido e eento e cineo de largo, afim de deixar na parte superior e inferior do quadro um espaço de nove millimetros para passagem das abelhas.

O eorpo prineipal tem exteriormente um resguardo sobre a entrada, e assenta na base, dos lados, por meio de um entallie interno de vinte e cineo millimetros de alto por dez millimetros de largo, e de tra\% por uma segunda parede de vinte e eineo millimetros de largo e trezentos e rinte millimetros de alto.

Para diminnir a capacilade da colmeia empregam-se divisoies moreis de madeila, de de\% a doze millimetros de espessura.

Os quadros sĩo cobertos com um panno de algrodão, tapete, oleado, etc., ou mesmo nma taboa fina, forrada de panno; esta taboa dere ter numa abertura ao centro, quando ao corpo principal da eolmeia tiver de se adaptar alças.

Esta colmeia póle sel augmentada com uma. duas e até tles alças, medindo cada una interiormente quatroeentos e eineventa milimetros de comprido, quatrocentos e cincoenta millimetros de largura e eento e sessenta e sete millimetros de altura, nas quaes, querendo, se introduzem quadros on seções.

A timpa, que tem duzentos e cineo millimetros de altura, adapta-se á colmeia por meio de reguas externas de dez millimetros de espessura, pregadas a toda a volta. O teeto, que é 
inclinado para dar facil escoante ás aguas, póde ser pintado com uma tinta alcatroada ou coberto de folha de zinco.

Um enthusiasta apicultor de Carregal, o ex. ${ }^{\mathrm{mo}} \mathrm{sr}$. dr. Adriano A. Garcia de Mascarenhas, baseando-se na facilidade que as abelhas teem em descer nos cortiços com as snas construcções cerificas, fez uma colmeia vertical, que parece de merito e que o auctor nos descreve da seguinte fórnua:

"A base d'esta colmeia só differe da colmeia Gariel em ser menos larga e em ter um quadro on caixilho de madeira sobre que assenta o corpo da colmeia. Este caixilho, que está pregado no parimento da colmeia, é formado por quatro reginas de madeira que teem quatro centimetros da largura e tres de altura.

A regna da frente tem nuna escavação de um centimetro de altura clestinada á passagem das abelhas. O caixilho tem as seguintes dimensões: cxternamente trinta e quatro centimetros na frente e quarenta e oito nos lados; internamente tem de menos a largura da madeira ou scjam vinte e seis centimctros de frente por quarenta nos lados.

O corpo da colmeia é formado de andares ignaes para que possam ajustar bem uns sobre os outros, e cada $1 \mathrm{~m}$ é constituido por dons cubos em caixas rectangulares, servindo uma para supporte dos quadros e a ontra para caixa de agasalho.

A caixa interna reccbe scis quadros, e, entre as paredes das duas caixas, fica um espaço vasio de vinte e cinco millimetros.

As caixas externas são municlas de cintas (tapa-juntas) e as internas pódem ter uns ganchos.

Arma-se a colmcia asscntando $11 \mathrm{~m}$ dos supportes dos quadros dentro do caixilho da base, que é unmido de $\mathrm{um}$ pequeno calço, de um centimetro de altura, em cada um dos sens quatro angulos internos. A primcira faixa de revestimento, que tem a nnenos das ontras dons centimetros em altura, assenta dircctamente sobre o caixilho dla base, que fica cintado pelo tapa-juntas na altura de um centimetro. Complcta-se o edificio sohrepondo os outros andares e o tecto. Os quadros dos faros são iguacs aos dos das ontras colmeias.

Para maior commodidtude das operações apicolas podemos dispôr janellas com vidros nos supportes dos quadros.

Uma colmcia de quatio andares comporta vinte e quatro quadros, tem de altura nitenta e nove centimetros contados do parimento até ao cinno dos ultimos quadros, e tem capacidade ponco inferior a setenta e cinco litros, » 
O typo de eolmeia simples de grandes dimensões, reclamando poucos euidados e menos sciencia, é a colmeia liorisontal Layens, de eonstrucção fria.

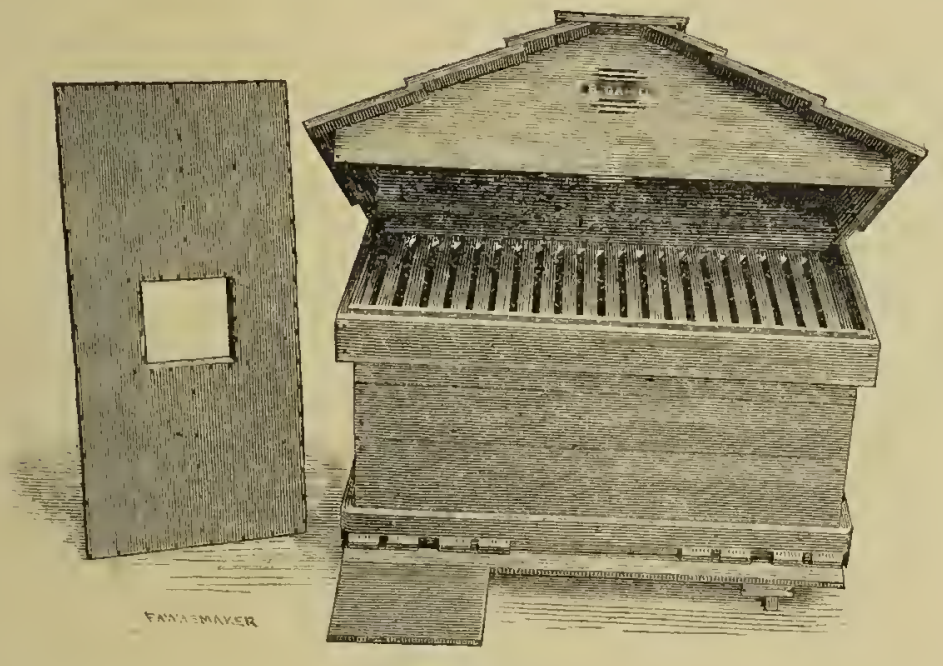

Colmeia Layens

Compõe-se a colmeia Lạens apenas de base, corpo prineipal e cobertura.

A base tem vinte e eineo millimetros de espessura, setecentos e oitenta e dous millimetros de comprido, e trezentos e noventá de largura, de modo a ultrapassar na frente dez a doze millimetros o eorpo da eolmeia, e é inferiormente reforçada eom duas fórtes travessas.

O eorpo ó eomposto de quatro paredes de trezentos e quarenta e cinco millimetros de largrura, seteeentos sessenta e sete de eomprido e quatrocentos e trinta e tres de alto, tendo lia frente e atraz, na parte superior, salieneias de dezoito de alto por doze e meio de largo, d'onde pendem os quadros. Inferiurmente, entalhes de rinte e cineo millimetros de alto e dez de largo nas paredes lateraes e traseira, fixam o corpo da colmeia á base. Na frente, em vez de 1 m só orificio de entrada, ao centro, tem dols, um em eada extremidarle, de oito millinietros de alto por duzentos e cincoenta de eomprido, que se 
abrem alternadamente, segundo a epocha e o lado onde se quer activar a construcção dos favos.

Externamente, nos quatro lados superiores e inferiores, correm reguas de madeira de vinte e cinco millimetros de espos-

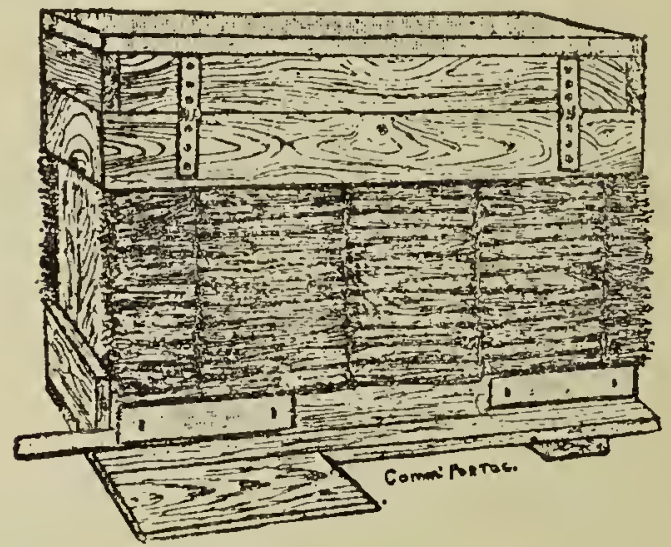

Colmeia economica Layens preparada para a hibernação sura e trinta de largura, de modo a deixar um espaço que, no inverno, é chcio com um revestimento de feno, palha, panno, etc., que se scgura á colmeia por meio de regnas de madeira de alto a baixo, presas ás reguas superiores e inferiores, sendo quatro em cada face, duas ao centro e uma em cada extremidade.

O revestimento de palha deve ser um ponco mais espesso na parte inferior para facilitar o escoamento das aguas pluviaes.

A cobertura, que possue orificios para ventilação, deve ter uma altura tal que dcixe um vasio de cento c trinta e scis millinetros acima dos quadros, afim de se poder, na epocha da grande producção, collocar sobre elles nma caixa com nove secções medindo $130 \times 105 \times 50$.

Os quadros, de madeira, teem quatrocentos e cinco millimetros de alto e trezentos e dez de largo, e, superiormente, uma travessa de trezentos c sessenta e oito millimetros de comprido. Em baixo são reforçados com mma travessa.

Cada colmeia Layens leva vinte e um quadros a $11 m$ a distancia de trinta e oito millimetros de centro a centro; tem, como as outras colmcias, duas separacões de madeira ou lata para, no caso de necessidade, se diminuir o espaço reservado aos favos.

Os quadros cobrem-se com uma tabua finissima, revestida 
inferiormente de panno de algodão ou linho, tendo ao centro uma abertura para dar communienção ás seçôes, abertura que se cobre com panno, quando se quel collocar sobre ella as secçōes.

A colmeia Gayton, horisontal e de eonstrucção quente,
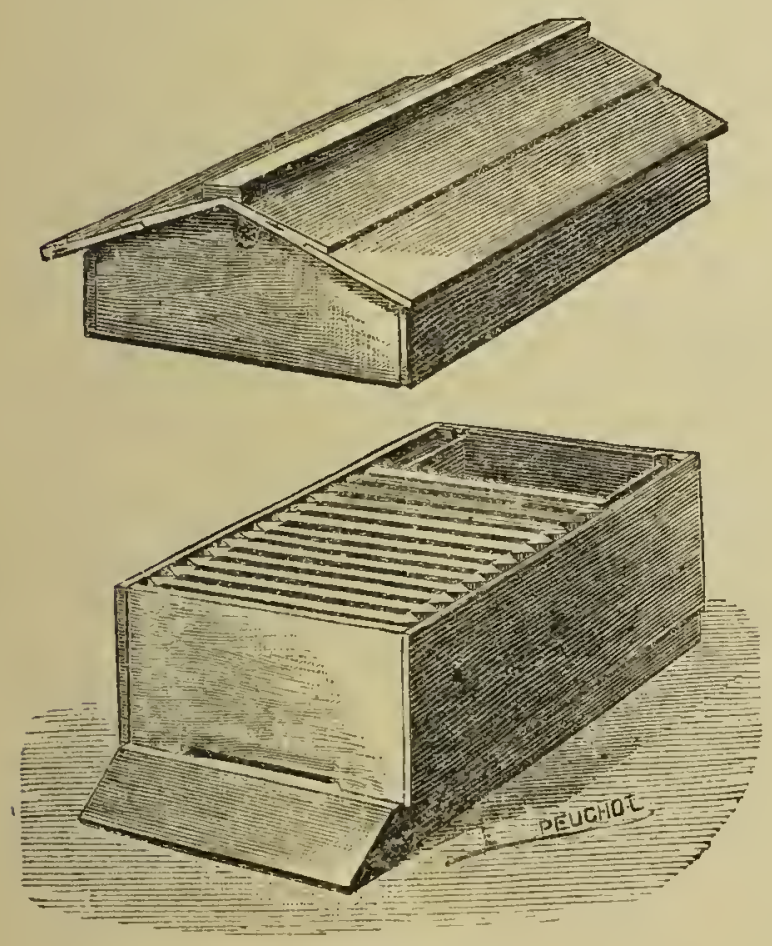

Colmeia Gaytou tem a rantagem de ser grande, muito simples e, por eonseguinte, mais barata que nenhuma outra.

A eolmeia Gayton eonstroe-se para eapacidades varias, desde dez até vinte quadios de $20 \times 34$ eolloeados sempre em sentido parallelo á entrarla. Pórle-se substituir; na epoeha da grande eolheita, alguns quadros de ereação por quadros com seeçoes, dispostos na parte posterior da colneia e separados dos quadros de creacão pol uma divisão de zineo, afin de evitar o accesso da mestra e eom ella a postura e armazenagem de pollen. Cobrem-se os quadros eom un panno grosso, tapete, oleado on panno pintado. A eolmeia Gayton é boa para regrióes ponco frias e pouco humidas.

Abbutt, o illustro redaetor do Brilish bee jommul, appesenton na exposição universal realisada em França, em 187s, uma colmeia, a que deu o nome, e que, no mesmo ammo, mereceu una medalha de prata no concurso da Associașão dos apicultores inglezes. 
N'esta colmeia os quadros, possuindo as dimensões do quadro classico, que as associaçóes apicolas teem procurado fazer com que seja unirersalmentc adoptado (35 a 56 cm $\times 21$ a $59^{\mathrm{cm}}$ ), estão collocados pelo meio da entrada, parallelamente á parede fronteira, em rez de lhe sercm perpendiculares, e possuem as extremidades salientes, formando espalda, o que permitte que sejam facilmente manejados.

Estes quadros conservam-sc á conveniente distancia requerida, por meio de dous fios de arame.

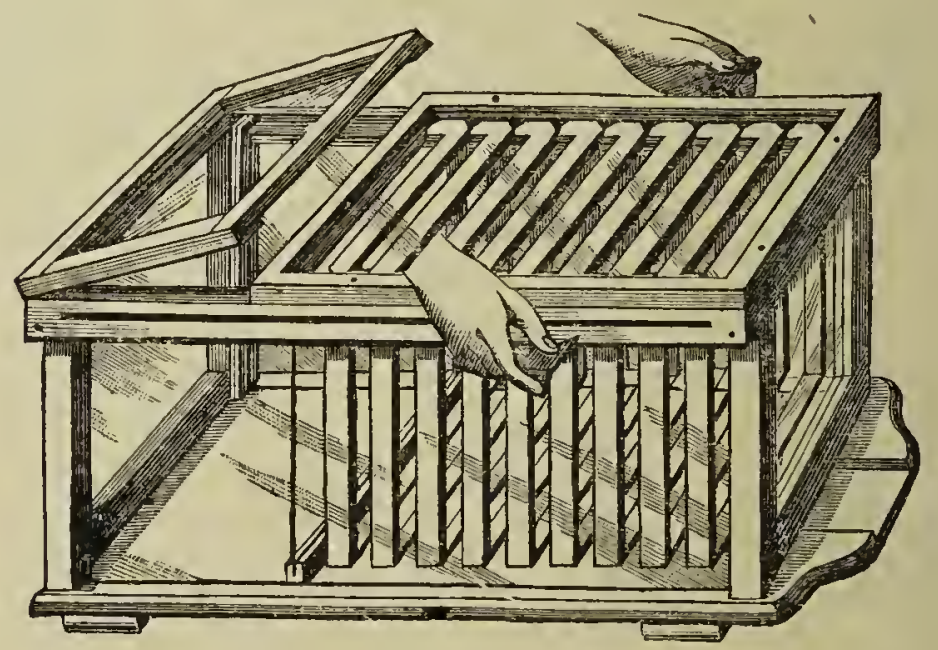

Colmeia Ablott

As dimensões mais geraes da colmeia Abbott são scessenta centimetros de comprido por trinta de largo levando de nove a quinze quadros, o que faz com que scja un armazcm de mel, pois, addicionando-lhe um andar, ou mesmo outra colmeia sobreposta, póde dar cincoenta a sessenta kilos de mel. A parte interna da colmeia apresentada na nossa gravura, entra $\mathrm{cm}$ uma caixa, com os espaços precisos á voltin, para serem, 110 inverno, convenientemente cheios com musgo, palha, feno ou mesmo trapos de lã.

Póde tambem ser guarnecida de vidros, transformanclo-a assim o seu possuidor, en uma boa colmeia de observação. 
Querendo introduzir-se-lhc secções devem estas ser scparadas dos quadros de creação por meio da divisão de zinco, que véda o accesso da mestra.

Esta colmeia tem a particularidade da entrada poder ser por qualquel dos quatro lados, segundo a conveniencia, ou ter mesmo duas ou mais entradas ao mesmo tempo. Alguns apicultores divirlcm-a internamentc em duas por meio de espessa grade de alame, ou de um quadro com vidro, e, dando-lhe duas cntradas distinctas, fazem n'ella traballar dous enxames diversos, o que parece ter motivado a IVells a ideia de sua colmeia dupla, de que mais adiante nos occuparemos.

Os quadios são cobertos como os das outras colmeias, e una tampa em telharlo, fecha-a superiormente.

A colmeia album Derosne, de systema horisontal, compõe-sc de uma caisa do comprimento de un metro e trinta c dous centimetros, da largura de quarenta e cinco centimetros e da altura de trinta e nove centimetros, fechada com madeira de tres lados, e na frente por nm chassis com vidros, que corrc facilmente em um encaixe proprio, podendo ser tirado quando se quizer.

Esta vidraça está usualmente coberta por uma portada, fixa por dobradiças á parte superior e por meio de ganchos á inferior. Possue a colmeia Derosue duas entradas desviadas uma la outra trezentos e quarenta millimetros, e dezoito quadros. Cobre-a uma tampa de tecto inclinarlo de bordos salientes, para sombrear a colmcia c principalmente a entrada, e é assente em uma taboa, na frente um pouco maior que a colmeia uns lez a quiuzc contimetros, em plano inclinado para facil accesso das abellıas.

Os quadros compũem-se de quadrós de creação e de armarcnagem de mel; cstes pódem ser construidos por doze seç̧õcs cada um e separados, já se rê, por as respectivas divisũes de madeira. 


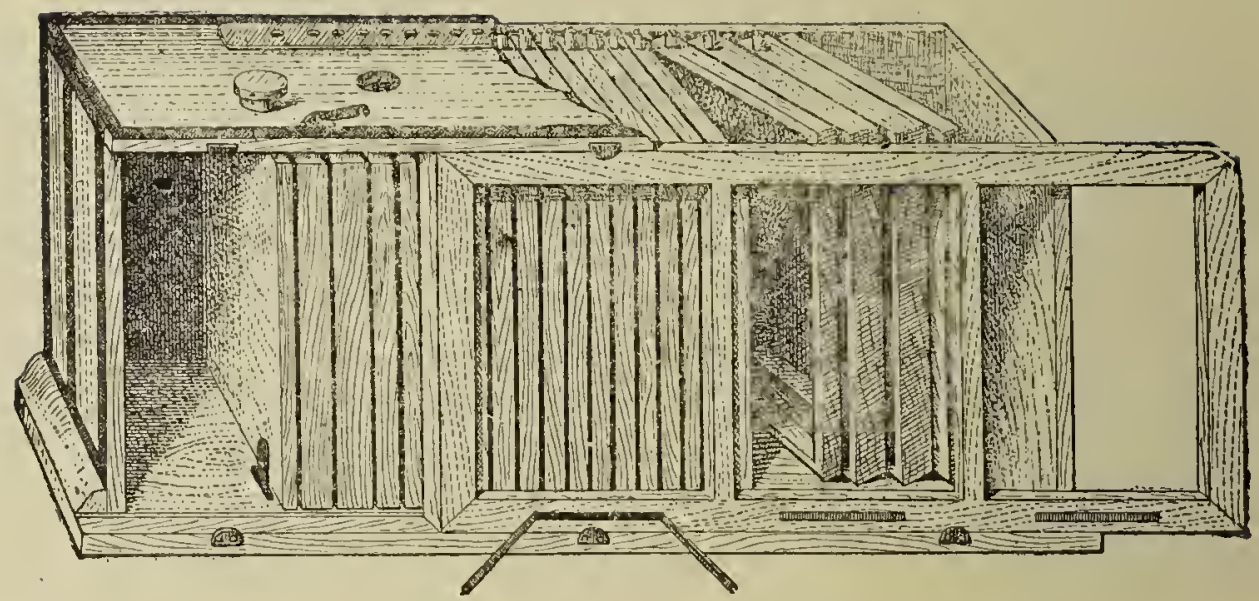

Colmeia alhnn Delosue

O quc torna notarcl esta colmeia, ó que os quarlros são n'ella dispostos como as folhas de um album, fixos em um cixo, que se póde facilmente manejar pela parte exterior. Assim, destapada a vidraça, ou mesmo corrida esta, desviam-se os quadros uns dos outros um a um, successivamente, sem incommorlar as abelhas, e rerifica-se sc a construç̧ão caminha bem, se a creação e colhcita é satisfactoria e se ha restigio da tinha ou qualquer outro perigoso inimigo.

No caso de ser preciso tirar algum quadro, desprende-se cste do eixo e puxa-sc por meio do um arame fino terminando em gancho na ponta.

Um apicultor inglez o sur. Wells imaginou recentemente um novo mcthodo de cultura las abelhas, que tem feito muito ruido, dando, segundo asseveram numcrosos apicultores, resultados notareis.

Consiste o methodo Wells em installar duas colonias completas cm uma mesma colmeia vertical e de construcção fria, muito grande, e dividida ao meio em duas por uma finissima rêde de arame, de modo que as abelhas das duas colonias não possam communicar umas com as outras, mas possuam todas 0 mesmo cheiro. 


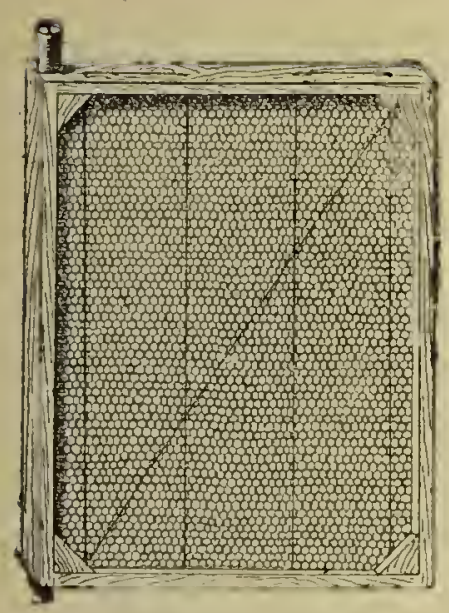

Quadro de creação

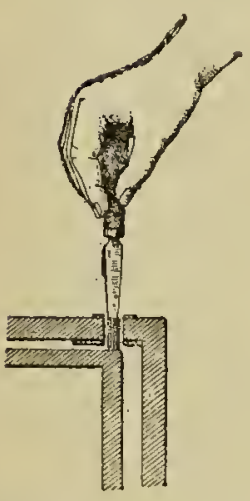

Ilodo de manobrar externamente os quadros

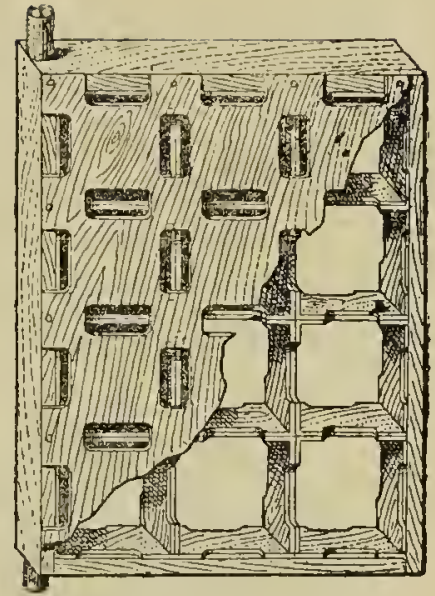

Quadro com secções

Como é por o cheiro que as abelhas distinguem as companheiras, tendo os dous euxames o mesmo cheiro é facil, quando se quizer, juntal-os sem haver animosidade alguma.

Ora isto é que é o pouto essencial do methodo Wells.

Durante uma grande parte do anno, as abelhas trabalham em separado, mas, chegada a epocha da grande producção mellifera, tiram-se os pammos que cobrem os quadros, substituem-se por uma grade de zinco que só dè passagem ás obreilas e conserve as mestras retidas nos seus compartimentos especiaes, e pũe-se a alça, ou alças com secções.

Assim, as obreiras misturam-se, fazendo juntas apenas a colheita e armazenagem do mel, pois continuam a constituil duas familias, cada uma com a sua mestra.

A culleita d'esta fórma é enorme, e o augmento da população muito grande, risto os uinhos de creação das duas colouias terem mais calor, por ficarem a centro, proximo da grade e portanto ambos juntos.

As entradas especiaes para cada enxame pódem ser ao meio do espaço da parte que the ó destinada na colmeia, ou quasi juntos ao centro da colmeia, e separados apenas por uma pequena lanina de madeira correspondente á grado de separação interna. Esta entrada, que farorece o utilissimo desen- 
volvimento da creação junto uma da outra, e faz com que a hibernação seja muito favoravel e com menos perda de calor, tem só o inconveniente dc, na occasião da renovação das abelhas mestras, quando ellas regressam fecundadas, poderem enganar-se na entrada, e serem mortas na colmeia estranlı. Para, atć certo ponto, attenuar este inconreniente, é muito ritil pintar de garridas côres diversas as duas inctades extermas da

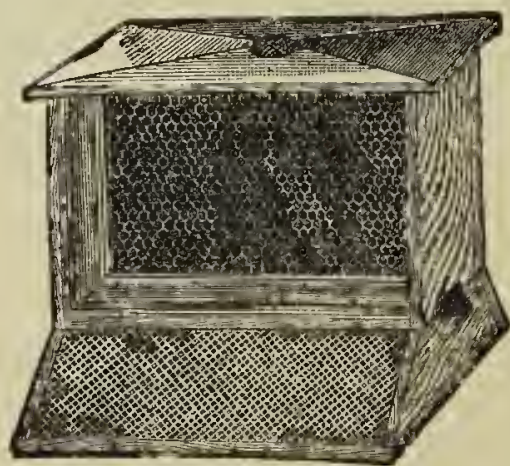

Colmeia de observaçào colmeia, correspondentes ás duas divisões internas.

Para a creação artificial de rainhas, e principalmente para sc seguir passo a passo o trabalho de construcçĩo das abelhas, í muito usada a colmeia de observação comportando um só quadro de $20 \times 30$, coberto na frente por um vidro resguardado com luma portada movel. A entrada das abelhas faz-se pelo lado na disposição perpendicular do faro, e, quando se quer rerifical o estado de adiantamento d'este ou vêr o movimento das obreiras, desce-se a portada e deixa-se o vidro a descoberto. .

Esta colmeia de observação póde estar installada em qualquer sala, com a entrada prolongada para fóra de uma janella, c ser assim examinado, a toda a hora, o trabalho das abelhas, sem receio das suas picadas. 


\section{A cềa moldarla}

A cèra moldarla ó o maior e mais importante auxiliar da apicultura mobilista. É ella que faz com que a construcção das abelhas seja muitissimo regular, dentro dos limites dos quarlros, e os favos completamente soltos uns dos outros.

Facilita além d'isso o traballo das obreiras, permittindo que, em menor espaço de tempo, produzam maior numero de faros, com economia de cerra, e, purtanto, com menor dispendio le mel, pois as abchas, para segregar um kilo de cêra, necessitam de absorver scte a dez liilos de mel.

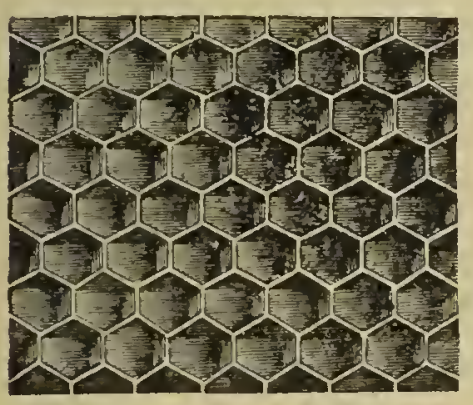

Cèra moldada para cellulas de obreiras

Erita a prejudicial abundancia das cellulas de machos, pois a cèra moldada, que enr regra geral se fornece ás abellias, leva unicanente os rudimentos de cellulas de obreiras e sú, raras rezes, quando a creação de maclıos é insufficiente, é que se the dá cêra moldada com alveolos de machos.

Isto, porém, quasi nunca é preciso, bastando, ao pôr a cèra moldada nos quadros, deixar n'uma das extremidades de cada um, o espaço de meio centimetro quadrado sem cèra, para as abelhas alli fabricarem as precisas cellulas de machos. 
Com o uso da cêra moldada, ha o aproveitamento, em benefieio das abelhas, da cèra velha e dos desperdicios los favos, dcpois da extracçño do mel, eêra que poueo vale, e que, depois de eonvenientemente eylindrada, dá a base dos favos, onde as abellas, em seguida á ereação da próle, arınazenam o delieioso e aromatieo mel.

No fabrico da cêra nıoldada dere ser sempre utilisada cêra pura e bòa, pois, sendo falsificada eom cèras vegetaes, as abethas regeitam-a, ou, sc alguma vez, levadas pela neeessidade a aproveitam, eliegado o verão o desastre é eerto, pois as eĉras vegetaes e mineraes, fundindo a uma temperatura muito mais baixa que a das abelhas, que funde a $64^{\circ}$ eentigrados, enquanto que a parafina funde a $44^{\circ}$, os favos deseonjuntam-sé, perdendo-se o mel, e o que é peor ainda, a creação n'elles contida; a eĉra tambcm nào dere ser branqueada por meio de aeidos, por isso que ás abellias thes repugna todo o cheiro mau.

Na cêra moldada eada faee da lamina é composta de bases de cellulas como no inicio dos favos naturaes, bases que são muito mais regulares e perfeitas que ellas quando as laminas são fabricadas ell cylindros bem gravados.

Preparam-se laminas eom alveolos de obreiras, laminas eom alveolos de maehos, e outras laminas muito finas, com alveolos proprios para armazenagem de mel, e destinadas sómente ás pequenas seçôes.

Foi o allemão João Mehring que em 1857 inventou a cêra moldada, fabricando-a en uma prensa rudimentar, que dava á eêra apenas uma leve impressão de eellulas.

O suisso Pedro Jaeob, alguns annos nais tarde, modificou bastante a descoberta de Mehring, mas o amerieano Root é que em 1876 a popularisou, tormando faeil o seu fabrieo por meio de cylindros de metal tendo gravadas as bases das eellulas. Hoje são vulgares em toda a parte onde se faz uso das colmeias moveis, existindo já muitos no nosso paiz, o que permitte a facil obtenção, por baixo preço, de boa cèra moldida entre nós. 


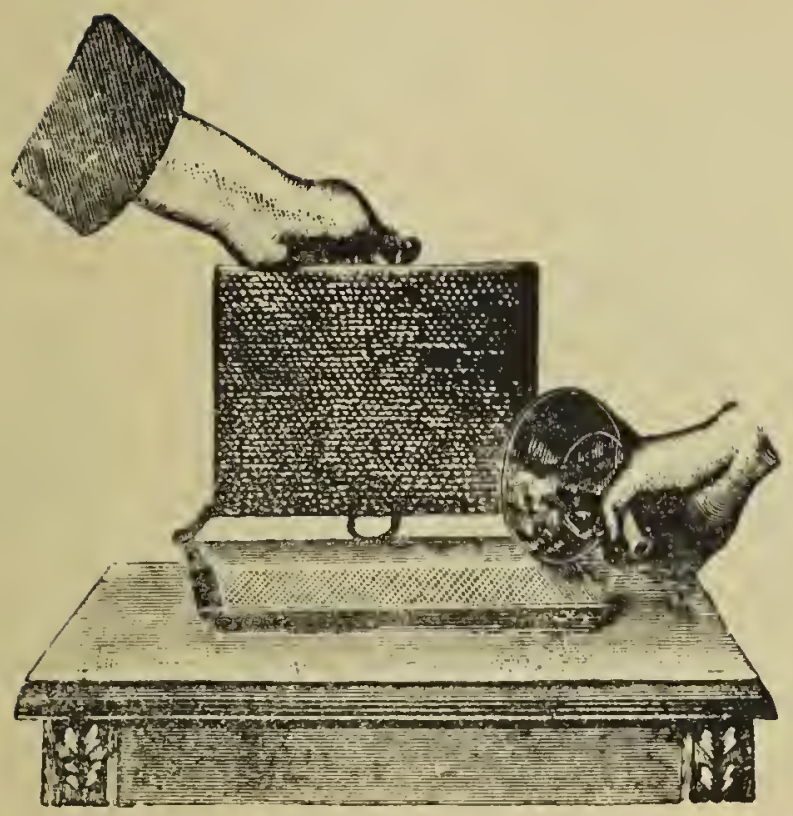

Prensa Rietsche

Para os pequenos apicultores basta a prensa Rietsche, de manejo simples e dando boas laminas de cêra.

Esta prensa funcciona da seguinte fóma: Abrc-se e limpa-se internamente, com cinza e agua, passa-se depois por agua pura e escorre-sc bem durante algum tempo. Em seguida, com uma escora propria para tal fim, unta-se bem com mel, colloca-se em uma superficie plana, deita-sc-lhe dentro a cềra derretida e fecha-se immediatamente. Antes da cêra arrefecer é conveniente, para que a lamina fique perfeita, cortar-lhe as rebarbas de cêra a toda a rolta do apparelho.

A prensa Rietsche, estando fria, dá lamiuas de cûra moldada de espessura regular, porém, se se pretendercm mais finas, basta aquecer lcremcute a apparelho antes de se the deitar a cêra derretida.

A cêra moldada obtida en prensa nunca é tĩo regular e perfeita como a extrahida das machinas de cylindros, pelo que sĩo estas rantajosamente preferidas em todas as exploraçoes importantes, e, principalmente, as unicas proprias para o preparo de cêra moldada destinada á renda. 


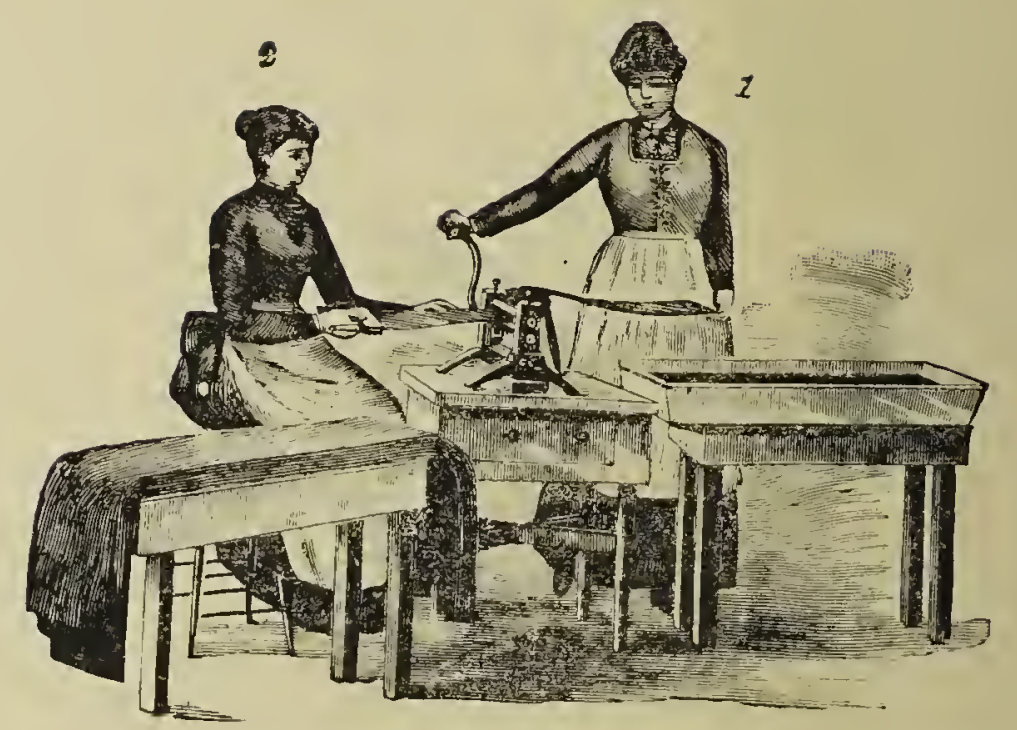

Cylindragem da cêra pelo cyliudro Root

A melhor de todas as machinas é a de cylindros, de Ront, possuindo dous rôlos, com a base das cellulas gravada, e entre os quaes passa a lamina de cêra.

Ao lado do apparelho, assente em uma mesa, dispõe-se uma tina com a cêra derretida, tina onde se mergullıa duas ou tres rezes a seguir uma plancheta de madeira sem nós, nem irregularidades, do tamanlıo da lamina a fabricar, e anticipadamente mettida em agua a ferver e enxugarla com uma esponja. Tirada da tina da cèra introduz-se em ontra com agua muito fria, e depois desliga-se a cêra que tra\% adherente em fina lamina, toda da niesnia espessura, que se guarda entre duas follas de papel.

Estas laminas de cèra deixam-se arrefecer durante oito dias em um local secco e frio, e, quando se pretender passal-as pelo cylindro, amollecem-se em uma bacia com agua quente, e uma qualquer pessoa mette-as d'um lado no cylindro e volta a manivella (1), emquanto outra as extralie do lado opposto (2) puxando-as com uma pinça de madeira, propria para tal fim, como claramente o mostra a nossa gravura. 
Para que a cêra não adhira aos rôlos é preeiso humedeeel-os constantemente com uma agua de sabão muito espessa, ou leve colla de amido.

Extrahida a cêra moldada dos rôlos eorta-se do tamanho requerido e empilha-se em sitio seceo e fresco, onde se póde conservar em perfejto estado durante muitos annos. 


\section{Calendario apicola}

Yamos indicar, em rapido resumo, os trabathos apicolas a executar em cada um dos doze mezos do anno.

Assim o principiante púrle, facilmente, saber para onde, mensalmente, tem de voltar a sua actividade, indo depois procurar mais larga explicação das operaçoes a realisar, nos respectivos capitulos especiaes d'esta obra.

\section{J A NEIRO}

Entre nús as abcllas sahem pouco n'este mez, que é sempre frio, c geralmente humido.

Portanto os cuidados do apicultor devem limitar-se a resguardar as colmeias o mais possivel do frio.

Se as colmeias estiverem em local onde neve com frequencia, é preciso cobril-as exteriormente com uim tecto de palha ou zinco, sahido om pouco na frente, para evitar que, quando o sol apparecer, entre por a abertura da colmeia c tente as abchlhas a saliir, o que thes scria funesto, pois caliriam de prompto geladas.

A abertura da entrada deve ser reduzida an minino possivel, não só para augmentar o calor interno, mas tambem para que, por ella, não possa introduzir-se na colmeia qualquer pequeno roedor on musaranho, que fariam grande destroço no mel e nas abelhas. 
Se se não tirer a certeza de que as abelhas possuem na eolmeia alimento sufficiente, ou se se começar a vêr apparecel abelhas mortas á entrada, examina-se a colmcia, abrindo-a cuidadosamente em dia temperado, das dez horas da manhã ás duas da tarde.

Faltando alimentaçĩo, introduzcm-se-llhe favos com mel, que devem ter ficado de reserva da colheita anterior, uu, não liavendo faros, assucar crystallisado, assucar candi ou em pasta, que sc dispõe na parte superior da colmeia, sobre os quadros.

De inverno nunca se devc dar sustento liquido, que ó sempre prejudicial, pois u’essa epocha ha na colmeia um constante excesso de lnmidade, devido á eraporação do mel e á respiração das abelhas.

Esta humidade, pois, ó bastante para, com prorcito, dissulver o assucar solido que fornecermos ás abcllas.

Feito isto, é preciso dcixar, o mais cuidadosamente possi$\mathrm{rcl}$, as abelluas tranquillas durante o invermo.

Como todos os apicultores sabem, quando, para qualquer manipulação, se provoca a agitação do enxame, as abelhas tratam de sc abarrotar de mel. Isto, alćm de diminuir desnecossaria e inconvenientemente as provisões, faz com que, não podendo digerir tão grande quantidade de mel, por falta de excrcicio, muitas abellas morram, o turlas viciem a atmosphera eom um excesso de respiração.

Como n'este mez as abelhas reguerem muito poucos cuidados, prepara-se a cèra moldada, fabricam-sc quadros, limpam-sc colmeias rasias, emfim dispôe-se o material para os mezes que segucm.

\section{FEVEREIRO}

Sio o mez so conservar muito frio, os cuidarlus são us mesmos de janciro. Porém, entre nós, os ferereiros frios sĩo laros; reralmente a tomperatura começa a adosar de modo que as abclhas cntran em actividade, sahindo $\mathrm{cm}$ dias de sol não sú á procuara de algum polleu das poueas flôres que appare- 
cem n'esta epoeha, mas, prineipalmente, tambem de liquidos. É preciso então vigial-as com todo o cuidado. Se salıem em abundancia, vigorosas, despreoccupadas, rae tudo bem na colmeia. Se, porém, se mostram indecisas á porta da colmeia, como receando sahir, ou trazendo cadaveres de oompanlıeiras, é preciso desconfiar de que alguma cousa de anormal se passa lá dentro a que é preciso dar prompto remedio. Póde ser falta de alimento, doença ou morte da mestra; qualquer d'estas cousas necessita ser verificada de pronıpto.

Aberta a colmeia, examina-se se tem mel nos faros. Não - havendo, dá-se-lhes, como já indicamos no mez de janeiro, sustento artificial. Havendo mel, e não sc rendo restigios de doença nem de creação, ou se predominarem as cellulas dos machos, é porque a mestra é esteril ou morreu. N'este caso é preciso, scm demora, ir busear-se a una colmeia vigorosa um quadro com creação, onde haja larvas com dous ou tres dias, e fornecel-o á colmeia fraca. Feito isto, colloca-se-llue sobre os quadros algum sustento, embora haja mel nos quadros, agasalha-se, feeha-sc a colmeia e deixa-se fiear em repouso atć março, em que ć preciso de novo examinal-a.

Se o mez correr tão quentc, que a actividade das abelhas vá augmentando día a dia, e a florescencia estiver atrazada, ó preciso pôr-lhes á disposição farinha, para substituir o pollen de que carecem para sustento da creação. A melhor farinha ć a das leguminosas, por ser a mais rica em materias azotadas, enpregando-se a das ervilhas e feijões; dispõe-se a farinha em pratos proximo das colmeias.

Tambem é indispensavel collocar, a dous ou tres metros de distancia das colmeias, pratos ou outro qualquer recipiente - menos fundo possivel, com agua levissimamente salgada, muito precisa para o bom desenvolvimento da creação.

Para que as abelhas possam facilmente lamber o liquido, cunvóm deitar-lhe a superfieie algum fluctuador, pequenas pallias ou rodclas de cortiça.

Este mez deve ser aproveitado para plantação de arvores e flòres proprias para pasto das abelhas. 


\section{A R ÇO}

Em maṛo já as abelhas estĩo entre nós em plena actividarle, colhendo nas flòres, que começam a vestir os montes $\theta$ us campos, o pollen preciso para o desenvolvimento da ereaşa que vae enchendo as cellulas dos faros centraes.

$\dot{E}$ indispensavel, agora, que thes não falte sustento, o que se devo verifiear com todu o cuidado. Como n'esta epocha a colmeia preeisa da maior quantidade de calor possivel, não se deve conserrar as aberturas da entrada demasiado largas, nem tirar-lhe os abrigos de inverno.

Se os feltros, pannos grossos on tapetes, que se collocam pol cina dos quadros, para, durante o inverno, ser conservado na colmeia o calor preciso, se mostrarem lmmidos, é necessario substituil-os por outros, ou, em nm dia muito quente, tiral-os, seceal-os ao sol, sacudil-os bem e tormal-os a collocar na colmeia.

Se houver falta de sustento, ou se se vir que não ha o preciso, fornece-se-lhes alimento solido, como no mez anterior, oll uma pasta que se prepara aquecendo um kilo de mel e unisturando-lhe quatro kilos re assuear. Esta pasta estende-se en 1 m panno, que se colloca por cima dos quadros.

Pórle tambem lar-se o easo de haver muito mel e poucos farus vasios para a creação; então tiram-se tres ou quatro quadros con mel e substituem-se por outros con faros rasios, on, hão os havendo, com laminas de eèra moldada.

Do exame da creaç̃o n'este mez é que se avalia o estarlo do ellxame.

Se a creação é densa, sem espaços razios, a mãe é nova fórte e hem fecundada; estando a creação disseminada, ou lavendo abuudancia de alreolos de machos, a mãe é velha, on doente, ou infceunda, sendo preeiso substituil-a.

Como já deixamos apontado nas instrueçues do me\% anteliur, a falta de creação, n’este mez, indica, sem o menor receio de erro. a falta da femea mãe.

Póde-se-lhe fornecer então un quadro com creação de 16 
dous dias, mas o melhor é juntar o enxame a outra colmeia fraca, fazendo assim um enxame fórte e apto para bem poder tratar de ruma boa postura feita por uma femea ninãe vigorosa. É o mez de marȩo o melhor para a mudança de enxames. Convém n'este mez que as abelhas, agitadas pelo movimento que se dá á colmeia para as operações da muda, se abarrotem de mel, produzindo assim una elevação de temperatura na colmeia, utilissima para o bem estar e bom desenvolvimento da creação.

Principia tambem, n'este mez, o periodo de vigilancia activa. Está a entrar a epocha em que os insectos nocivos flagellam as pobres abellias, em que mais se accentuam as doenças parasitarias, em que as abelhas reclamam maior attenção e os maiores cuidados.

Preparemo-nos, pois, para as asperas fadigas dos mezes que seguem.

\section{A B R I J}

Com o abril começa em Portugal a primavera. Por torla a parte apparecem flòres, onde as abelhas pódem colher o pollen e o nectar preciso para o sustento proprio e para o da creação, que começa a encher os alveolos dos faros centracs da colmeia.

É chegada a cpocha cun que convém forneccr-lhes sustento estimulante, não só para auxiliar o graude trabalho do fabrico dos favos, mas tambem para que, nem um momento só, falte alimento ás abelhas e diminua por isso o calor do intcrior da colmeia.

Se no mez de abril as abellas tiverem de estar exclusivaunentc limitadas á colheita diaria, póde acontecer, com als frequentes e bruscas variantes atmosphericas, que n'este mez se costumam dar entre nós, que não possam sahir um, dous ou tres dias.

Faltando o sustento pára todo o trabalho da colmcia, e, o que ć peor, diminue o calor preciso para o desenvolvimento 
das larvas, que morrem então mais pelo frio do que por falta de alimentọ, e apodrecem nos alveolos, originando a loque, pouco frequente ainda en Portugal, mas que já vae apparecendo devido á nociva importação crescente das abellas italianas.

Com snstento bom e abundante a actividade da colmeia rae sempre ell auguento; ́s sabido que, quanto maiol ereação houver na primavera, mais mel ha no fims do verão, e methor c mais fórte fica a eolmeia, podendo resistir aos variados ineonrenientes do nosso inverno.

É por isso que todo o bom resultado futuro depende dos enidados prestados ás abelhas nos mezes de março, abril e maio.

O alimento estimulante eonvém sempre que seja liquido; mas ha aqui tambem a attender, que é indispensarel haver o maior cuidacto no formeeimento d'este alimento, para evitar a pilhagem.

As abclias, encontrando perto da eolmeia alimentos artificiaes sempre en abundaneia, perdem o habito do trabalho, entregam-se a rapina e á lueta, invadindo, quando esfomeadas, as colneias que the estircrem proximo, pôndo-as a saque e destruindo-as quasi por eompleto.

Para cvitar este grande e prejudicialissimo inconveniente, collocam-sc os alimentos artificiaes distantes alguns metros da colmeia, c sempre em pequena quantidade.

Como já 110 decorrer d'estc rolume deixamos dito, lia alimentadores proprios, que só deixam sid-
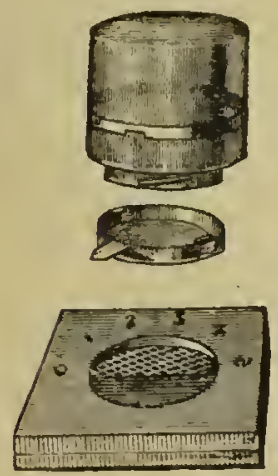

Alimentador graduado hir pequenas e graduadas quantidades de liquido, evitando-se assim facilmente a pilhagem.

O melhor que eonhecemos ó o alimentador de vidro, gradualo, de que já temos feito grande uso, sempre con bonı exito.

Convém recordar aqui que o mais apreciarcl alimento artificial sc prepara dissolvendo em cinco litros de agua a 
ferver dez kilos de assucar, tres kilos de mel e cincoenta grammas de sal; se nas colmeias houver loque, junta-se ao prcparado uma gramma de acido salicilico por cada litro de liquido.

O sustento estimulante deve ser distribuido na proporçĩo de um quarto de litro a meio litro por semana, para carla colmeia.

Durante o dia póde-se conservar meio abertas as entradas ou a entrada da colmeia; mas, como as noites de abril são sempre relativamente frias entre nós, conrém, ao anoitecer, apertar as entradas, que se alargam de manlia depois de nascer o sol.

Examina-se se a timka começa a fazer estragos; no caso affirmativo, por meio da pinça, apanham-se no interior da colLaiva da tinha meia as larvas que alli existirem, quer nos favos, quer entre os quadros e as paredes da colmeia, quer nos recantos d'esta.

Tanıem é convenientissimo proceder-se, diariamentc. á caça das borboletas da tinha; agarram-se facilmente collocando, an anoitecer, proximo das colmeias, uma luz intensa. As borboletas réem voar á volta d'ella e bater de cucontro á luz, sendo então facil apanhal-as á rède; quen não cstiver habituado a agarral-as da fórma indicada, póde collocar uma lanterna com os vidros untarlos a oleo, em um supportc pousado no centro de una bacia cheia de agua, ou, melhor, cheia de oleo on azeite. As borbolctas, batendo no vidro, sujam as azas e caliem no liquido, onde morrem sem remedio.

Quantas mais borboletas de tinha forem mortas na primavera, menos tinhas ba no outono, epocha em que tantos cstragos causam nas colmeias. o mez de abril ć igualmente o

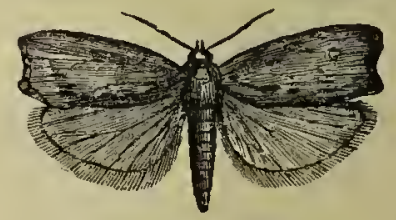

Borboleta da tinha melhor mcz para se proceder á pintura annual das colmeias, pintura que deve ser de côr diversa de colmeia para colmeia, 
afim de, quando a mestra nora sahir para ser fecundada, não se chganar na casa, e ir parar a uma estranlia, onde saliiria irremediavelmente morta.

Se as abelhas construirem algum favo irregular, deve ser tirado e substituido o quadro, que o tiver, por ontro com cêra moldada, ou, se o houver, com um quadro com un favo rasio, o que é muito melhor pela economia de mel c de tcmpo que as abchas rcalisam d'essa fórma. Havendo favos de machos en excesso, tambem se destroem, assim como as cellulas de mestras que passarem além de tres.

Começando a apertar o calor, póde-se tirar á colmeia alums agasalhos, mas gradualmente e não todos de uma ve\%.

\section{A I O}

O mez de maio é o mez de maior actividarle nas colmeias. En virtude da larga abundancia de sustento, a creação augmenta c prospera extraordinariamente $110 \mathrm{mez}$ das rosas e das flòres.

É a epocha da enxamagem natural, que facilnente se regularisa nas colmeias moveis, evitando-a pela addição de alças, ou pela divisão de colmeias, tirando, para isso, dons, tres ou quatro quadros com creação e com as obrciras que o estiverem cobrindo.

Estes quadros servem, ou para com elles se constituir novas colmeias, on para fortalccer colmeias fracas. No caso de servircm para organisar novas colonias, é preciso que lercm nos alveolos larvas de um ou, quando muito, de dous dias, e sufficiente população de obreiras para as cobrir e tratar d'ellas; tambem, como as obreiras não são sufficientes para cuidar da creação e perdem tempo na apanha do pollcn e nectar preciso, é indispensavel fornecer-lhe durante quinze a vinte dias $10 \mathrm{~m}$ bom sustento estimulante e alguma farinha em pó.

o espaço que fica vasio na colmeia mãe, enche-sc com noros quadros com cêra moldada, on, mellıor, com favos rasios, 
des despejados ao extractor, para assim as abelhas os utilisarem na postura e principalmente na armazenagem do mel.

Os enxames naturaes, assim chamados por levarem a mestra vellı, costumam salıir por toda a scgunda quinzona de maio, das dez ás tres horas da tarde; oito dias depois da sahida do enxame primario sáhe o segundo enxame, a que se dá o nome de garfo, por levar uma mestra infecnnda, nascida pouco tempo antes da sahida.

Os garfos abandonam geralmente a colmeia depois to meio dia.

Se a colmeia estiver muito fórte, ainda póde dar um terceiro e até quarto garfo, mas sempre scm valor, em virtude do pequeno numero de abcllas obrciras que acompanham estas mestras não fecundadas.

A enxamagem artificial, essa só deve ser feita en colmeias fórtes e muito populosas.

Como disscmos, quem não quizer que a colmeia enfraqueça pela salıicla de enxames, o que faz com que, pela diminuição de população, o mel colhido scja en peqnena quantidade, deve proceder de fórma que, á medida que a collıcita fòr em angmento, a habitação, isto é, o espaço para arnızenagem angmentc tambem.

Por isso, logo que o tempo quente se accentne e a floresconcia seja abundante, colloca-se uma prineira alça; é preciso haver semprc todo o cuidado na epocha da collocação da alça, para que não scja collocada cedo de mais, porque, arrefeccndo o interior da habitação, prejudicaria a creação, nem tão tarde, que seja motivo de dinninuição da collıeita e, portanto, cvite o respectivo augmento da população.

É tambem a segunda quinzena do $1 u \mathrm{cz}$ de maio a epocha mais propria para a obtenção artificial de abelhas mestras, o melhor meio que o apicultor mobilista tem ao seu alcance para evitar decepções e possuir sempre colmeias fórtes e bem poroadas.

De quinze de maio em diante convém evitar a mais insignificante visita ás colmeias, para não agitar inutilmentc as abelhas prejudicando-lhe o trabalho. 


\section{JUN HO}

Fi este, cntre nós, um dos mezes cm que o apicultor precisa olhar com a mais cuidadosa attenção pelas suas colmcias. Ten de vigiar pelo bom estado dos cnxames novos e verificar quc não haja o menol obstaculo que prejudique a colheita de mel feita pelos enxames rellos.

Se hourcr extraordinaria abundancia de flôres, e as seções estiverem cheias, conrém tiral-as o mais depressa possirel, pois, depois de cheias e opcrculadas, quanto menos tempo sc demorarem na colmeia, mais bellas e perfeitas ficam.

Se, ao tirar as secções, no principio do mez de junlıo, se vir que o corpo da colmeia está cheio com faros de mel, póde-se pôr uma segunda serie de secções, todas cheias com cêra moldada afin de serem extralidias con o restante mel da colnicia por todo o mez de jullı. Isto, já se vê, se houver flôres que permittam, durante o me\% de junlıo, uma boa collıeita de mel.

A flora da região é que dere ser a grande reguladora da collieita de mel. Se a florcscencia se demorar até setembro, convém fazer a colheita de mel em julho; se as flôres terminarem com o mez de junho, então faz-se a collıeita n'este mez.

Em. Portugal, porém, a extraç̧ão do mel é geralmentc mais proveitosa em julho do que em junlı, visto, em virtude da bcnignidare do clima, a creação il até tarde eritando-sc, como acontece áquelles que a realisam cedo, terem de inutilisar muita creação, que cutão se encontra nos faros, com grandc prejuizo da vitalidade futura da colmeia.

A vigilancia nas colmeias rellas deve tambem estender-se a eritar que, estando fórtes, depois de terem enxamcado cm maio, lêem mais enxames secundarios em junho, como muitas rezes acontece. Para isso, no principio de junho, verifica-se se nos quadros do ccntro da colmeia la cellulas do mestra, que, no caso affirmativo, se destroem por complẹto.

A sahida de enxames tardios, fúra do tempo, o o que ha 
de mais prejudicial, pois enfraquecem espantosamente a colneia, não prestando para nada taes ellxames serodios, que morrem geralmente no inverno, por falta de populaçào precisa para que na colmeia haja 0 calor indispensavel para as abelhas poderem atraressar beni a epocha fria.

No caso de se não poder obstar á salıida de algunı enxame serodio, o unico remedio que lia, é remnil-o a outro qualquer enxame fraco, salvando-se assim os dous, ou fazel-o reentrar na colmeia d'onde sahin.

Se a flora da localidade escassear cedo, não havendo nas colmeias o mel preciso para o sustento da sua população, ó indispensarel leral-as para sitio onde a colheita abunde; geralmente os nossos montes fornecem em junho e julho um magnifico pasto para as abelhas, $n$ m mel de primeira ordem sob todos os pontos de vista.

Se o calor se accentuar e as colmeias não estiverem abrigadas do ardor do sol debaixo de qualquer arrore, é indispensavel abrigal-as com cobertos de palba, afim de que, interiormente, os favos não amolleçanı com a clevação de temperatura, e 0 mel corra pela colmeia, levando a perturbação ao enxame e provocando a pilhagem sempre de effeitos terrivelmente desastrosos.

\section{JULH O}

É o verdadeiro mez da colheita entre nós. Convém começar a fazel-a nos primeiros dias do mez, não só para preservar o mel dos estragos que os excessivos calores pódem occasionar no interior da colmeia, mas tambem para obrigar as abelhas a continuar a colheita durante o verão, especialmente nas flôres dos montes e margens dos cursos de agua.

Para que o mel seja de primeira ordem é preciso haver a maior selecção durante a colheita, que dere sempre ser feita com tempo secco, apartando-se cuidadosamente os quadros onde liaja pollen e mesmo um ou ontro alveolo com creação.

Os favos que estiverem perfeitos, bem operculados, sem 
restigios de pollen nem de creação, são reunidos a um lado; os restantes juntam-se a outro.

Os quadros extralıem-se facilmente da colmeia, onde as abelhas os adherem por meio

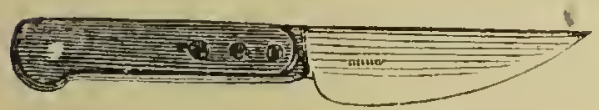

Faca para extrahio os favos de propolis, com o auxilio de uma faca grossa ou cinzel fórte.

Durante a operação fumigam-se levemente as abelhas, para as obrigar a estar socegadas e tornar mais facil o trabalho.

Os quadros com faros, á medicla que são tirados, guardam-se em uma caixa, que se tem ao lato e onde se feclam, e os espaços que ficam vasios na colmeia, enchem-se com quadros, com cèra moldada, on, melhor, com quadros com faros esrasiados ao extractor, se os houver de reserva.

É preciso que fique sempre em carla colmeia a quantidade de alimento preciso para o sustento das abelhas, durante ó inverno. E como se não póde ter confiança entre nós, na segunda colheita do verão e outono, é preciso sempre que a reserva a deixar seja sufficiente para as abelhas atraressarem perfeitamente o inverno, partindo do principio de que cada colmeia rertical usual necessita de dezeseis kilos de mel, pelo menos, e curla quadro, perfeito e completo, regula entre tres a quatro kilos de mel.

So a colmeia que risitarmos não tiver essa quantidade approximada, i preciso juntar-the mais faros com mel, extrahidos de outra colmeia.

Os quadros de provisóes rennem-se no centro da colmeia e os quadros rasios dispĩem-se dos dous larlos d'ella.

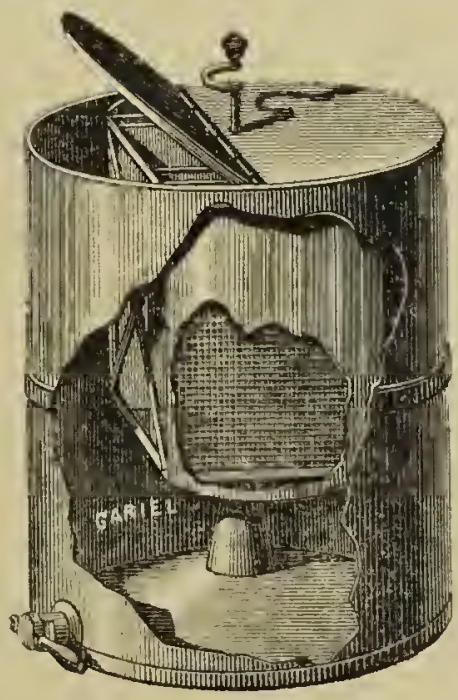

0 extractor 
A caixa onde, durante a colheita, se guardaram os quadros com faros, leva-se para um sitio distante, uma sala espaçosa, onde se deve proceder á extracção do mel.

Para isto é indispensavel o emprego do extractor, o melhor apparelho de que o apicultor mobilista póde fazer uso. Com o extractor não só se obtem mel purissimo, mas tamben faros vazios, que, no momento opportuno, pódem ser fornecidos ás abelhas, poupando-lhes o trabalho e tempo perdido no fabrico d'elles, e pernittindo-lhes o prompto aproveitamento de uma boa collueita do nectar das flòres ou do nectar especial de dadas plantas, como por exemplo da tilia, da borragem, da urze, etc.

Se os quadros extrahidos ainda trazen adlerentes algumas abellıas, sacóde-se fóra da janella varrendo-as com as barbas de uma penna de pato; depois, com uma especie de faca de lamina larga, chamada desoperculador, levemente

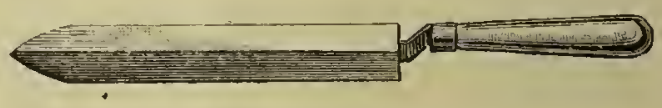

0 desoperculador aquecida, tiram-se, passando-a levemente pela superficie do favo, todos os operculos que tapam os alveolos cheios de mel.

Desoperculado o faro dos dous lados, introduz-se o quadro no extractor, que se põe em movimento; despejado o favo de un lado, tira-se o quadro do extractor e volta-se para se despejar o faro do outro lado.

Em dous minutos tem-se o favo vasio, sem soffrer o menor estrago, e o mel correndo purisssimo, por uma torneira que la no fundo do extractor.

Depois de extrahido todo o mel de primeira ordem, extrahe-se o dos faros com pollen e alveolos não uperculados, que dão um mel inferior, de segunda classe, e por ultimo submette-se os restos a uma prensa, obtendo-se ainda um terceiro mel, grosseiro e muito ordinario, que é preciso applicar promptamente, pois fermenta rapido.

'Terminada a operação, lava-se e limpa-se cuidadosamente - extractor, e os quadros vasios guardam-se em sitio secco 
e resguardado dos ataques dos insectos, e, sobretudo, das tinlias, para serem utilisados em tempo conreniente. Os que ficarem defeituosos, ou os que não se pretenderem para rescrva, jullaulse na prensa, onde se cxpreme ben a cêra, com a qual se fórma grandes bólas ou pães, o mais com-

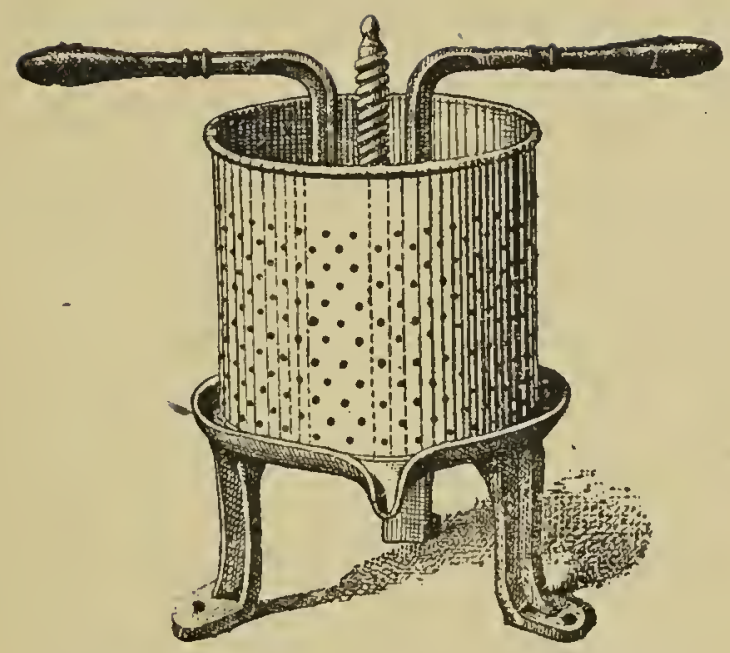

Prensa para extrahir o mel dos restos dos faros

primidos possivel, que se guardan igualmente em sitio enxuto afiu de serent preparados mais tarde, quando as colmeias não requererem tantos cuidados do apicultor.

O mel extrahido deita-se cm grindes vasilhas bem fechadas, onde se deixa estar durante algumas semanas, e depois passa-se para os frascos de vidro, grós on lonça vidrada, que o derent conserral definitivamente.

Depois da extraç̧̃̃o dos quadros com mel é preciso rigiar com toda a attenção as colmcias, por causa da pilhagem e dos ataques da Splimx atropos, a enorme borboleta, que se está propagando muito no paiz, e que é extraordinariamente gulosa por mel, entrando nas colmeias de noite e fazendo n'ellas estragos apreciaveis.

Tambem ó em julho que a pulga das abellas, a Brantce cacca, apparece em maior abundancia. Estando, porém, as colnicias bell poroadas, fórtes, c de saude, pouco lia a recear os cstragros da Sphinx, da Pulgu e até das Tiuhas on Treças.

\section{A GOSTO}

Convém, 110 principio d'este 11 ez, examinar cont todo o cuidalo as colmeias, e verificar-lhe o estado da populaçĩo, não 
só sob o ponto de vista do bem estar, mas tambem do da quantidade.

É indispensavel rêr-se se na colmeia ha sufficiente quantidade de abelhas que garantam uma boa hibermação; se teem o alimento preciso: se não ha indicios de doenças, e se a mãe se apresenta rigorosa e fórte.

Toma-se cautelosamente nota do estado de cada colmeia, afim de mais tarde se proceder em conformidade com o decorrer do mez.

Se o tempo sc conservar quente, constantemente de sol, pouca esperança póde liaver na colheita de agosto; ć preciso então fornecer favos supplementares com mel, áquellas colmeias que mostrarem não possuir quantirlade d'elle sufficiente para todlo o inrcrno. No caso de não haver, ou de se lhe não queres dar faros com mel, é forçoso sustental-as, de outubro em deante, com xaropes fabricados segundo as varias fórmas conhecidas. Se, porém, o agosto correr lıunido, que permitta - desabrochar das flôres da epocha, as abellıas ainda fazem então uma boa colheita, dando até mel em excesso, que se lhe póde extrahir no fin do mez.

Em geral não aconselhamos esta segunda extracção do mel, sendo preferivel deixal-o na colmeia, a não ser que ellc seja em quantidade tal, que mais tarde, na primavera, prejudique a postura da abelha màe, deixando-llıe nos faros um espaço livre excessivamente reduzido.

Se a colmeia estiver fraca, convém reunil-a a outra em identicas circumstancias, fazendo-se de duas colmeias más, que não poderiam resistir aos frios do invermo, ou se resistissen ficariam sempre fracas, e sem valor, uma colneia fórte e boa.

Tambem, como já temos deixado dito, se póde fortalecer uma colmeia fraca com quadros com abelhas, tirados de varias colmeias fórtes.

Mas, para isto, ć preciso nunca esquecer dar antccipadamente a todas as abelhas o mesmo cheiro, deitando-the dentro da colmeia, ou uma pedia de camplora ou de naphtalina. Assim não ha lucta. . 
Se o mez de agosto fòr excessivamente secoo e quente, torna-se necessario a maior c mais attenta rigilancia para evitar a pilhagem, por isso que as abellhas das colmeias fórtes, não encontrando flùr alguma onde possam ir colbcr o nectar, assaltam as colmeias fracas, c saqueiam-as, levando-lle a assolação e a morte.

No caso de se rerificar a tcndencia das abethas para a pillagem, reduz-se, o mais possivel, a entrada das colmeias amcaçadas, c, em ultimo extremo, fecham-se, deixando só sahil as abelhas durante muito poucas horas do dia.

Tambem se póde recorrer ao fumigador mechanico, que sc põe a funccionar junto da abertura da colmeia ameaçarla.

A diminuição de entrada nas colmeias, n’este me\%, c nos que se lhe segucm, atć naaço, tem tambem a utilidarle de critar a entrada dos insectos inimigos, especialmente da spllivi. atropos c attenuar os ataques las limhas.

Mas se, apesar das abelhas estarem fórtes, sc rerificar quc na colmeia não existe mestra, on que ella esta volha e fraca, agarra-se c mata-se, substituindo-a por uma nova, das que todo o apicultor deve ter em reserva, creada artificialmentc.

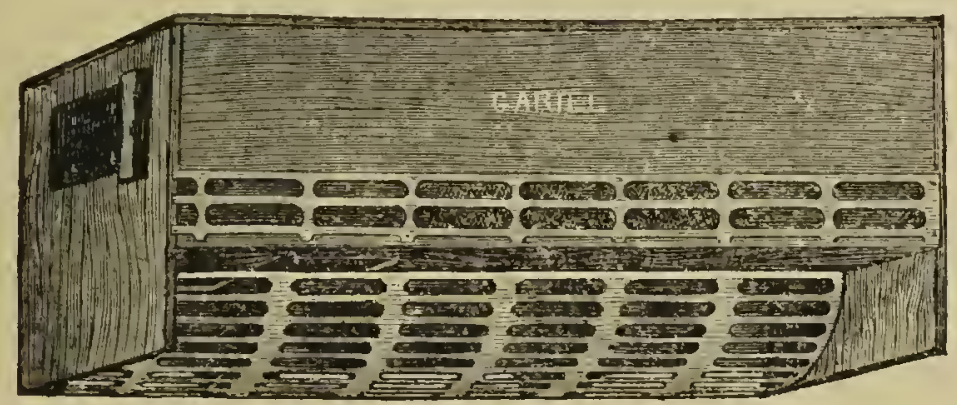

Armadilha para apanhar zangàoses

Tamben sc hourer muitos zangios na colmeia e as ahethas comçaren a expulsal-os, deremos auxilial-as n'esta tarefa da suppressão de bòcas inuteis, apanhando c matando os zangãos por meio da armadilla propria para tal fim. 


\section{SETEILRO}

Se o agosto corren favoravel á colleita das abelluas, permittindo que desabrochassem perfeitamente as flòres da epoclıa, póde adiar-se a visita ás colmeias para os primeiros dias de outubro.

Se, porem, o agosto foi nau, e, durante elle, as abelhas não encontraram pollen nem mel nos valles e nos montes, se as cluras demoradas se fizeram sentir, é indispensavel correr as colmeias uma a uma, e rerificar nellas o estado das provisões para o inverno. É facil verificar nas colmeias moveis a qnantidade de provisões existentes, sabendo-se que cada tres decimetros quadrados de faros clieios nas duas faces, teem approximadamente $1 \mathrm{~m}$ kilo de mel; ora como uma população vigorosa de cada colmein movel vertical, do systema mais seguido entre nós, precisa de quinze a dezoito kilos de mel para bem passar o inverno, facil ć verificar-se, en uma rapida inspecção, se ella tem ou não o alimento preciso para não haver frio nem fome durante os mans mezes do anno.

Marcam-se as colmeias que teem mel em abundancia e as que o não teem, para estas șerem mudadas para outro local onde possam ser mais cuidadosamente vigiadas, e onde seja mais facil dar-llıes a precisa alimentação artificial.

As flòres do ontono pódem dar ainda este mez algum mel, porém não se deve nunca contar, de fórma alguma, com collieita tão duvidosa.

Por isso, cstando a colmeia excessivamente fraca, ó indispensavel reunil-a a outra para a não perdermos por completo. O recurso de reduzir o espaço da colmeia, tirando os favos desoccupados, é de pouco valor, c só póde retardar, mas não impedir a extincção do enxame.

Póde-se deixal estar ainda os ventiladores meio abertos durante o dia, mas convém não esquecer de os fochar durante a noite.

Se ha ainda colmeias com alças, tiram-se e põe-se n'ellas, 
assim como em todas as restantes colmeias, um tapete fino sobre o panno com que se cobre os quadros.

Reduz-se a abertura dos orificios da sahida a uma largura de cinco a seis centimetros, e, como no $\mathrm{mez}$ de agosto, rigiam-se cuidadosamente os inimigos das abelhas, cujos ataques são sempre mais de temer nos mezes de inverno, mezes em que os prestimosos insectos mènos se póden defender.

Vae-se dispondo tudo para o preparo e acondicionamento do mel em vasilhas proprias para a venda, e para a purificação da cèra, tarefas estas a que o apicultor póde e deve dedicar-so de per si, nos mezes em que as colmeias the reclamam polico tempo e trabalho.

Quanto mais tentador fòr o aspecto das rasilhas onde o mel estiver exposto á renda, quanto mais bonito fồ o seu adorno, tanto melhor e mais facilmente elle se vender'í. O mercado do mel está por explorar entre nós. É preciso introduzil-o en todis as casas opulentas, fazer com que todos os abastados saiban quão delicioso ó o producto puro e bom tratcedo das boas e canccirosas abchas.

\section{OU'TUBRO}

Em outubro começam os preparativos de libernação nas colmeias moreis. Se a primeira quinzena de outubro se aprosental, como acontece muito frequentemente entre nós, secca e de sol, não ó preciso reforçar, señ̃o no fim do nez, a cobcrtura clos quadios.

Porém, se logo deste o principio do me\%, se fazem sentir os frios e als cliuvas, o preciso dispòr sobre o tapete, que já dere cobrir os quadros, $11 \mathrm{~m}$ feltio grosso on um segundo tapete bein encorpado.

A abertura de entrada, no caso do tempo correr frio, redu\%-se ao minimo, e o rentilador conserva-se aberto apenas durante as horas de sol e nunca de noite.

E conveniente inclinar un pouco para a frente as colmeias, 
afim de haver prompta e facil sahida dos liquidos da evaporação condensados na parte inferior da colmeia.

Durante o inverno a respiração das abellas, aggromeradas 110 centro da colmeia, o excesso de calor interno e a craporaș̃o da parte liquida do mel, dão um acerescinı de humidade, que é conveniente que tenha facil sahida pela inclinação da colmeia, para não provocar doenças de difficil e custoso tratamento, na peor epocha do anno para estes utilissimos insectos.

Tambem é preciso então segurar muito bem as colmeias, afim de que os ventos fórtes do inveruo as não possam tombar nem causal-lhe o mais leve abalo.

Se apparecerem colmeias fracas que não foi possivel reunir a outras e que não podéram fazer colheita precisa para as abethas bem atraressarem o inverno, fornece-se-lhes favos cheius de mel, dos que sempre se deve ter de reserva para tal fim. Não havendo faros, dá-se-llies sustento sólido, assucar candi, mel crystallisado amassado com assucar e posto en um panno por cima dos quadros, e mmeca sustento liquido, que só deve ser fornecido na primavera. O sustento liquido precisa de ser completamente prescripto de setembro em deante.

Eutão as abelhas não pódem fabricar já os favos precisus para bem acondicionarem o liquido colhido, e mesmo, dandose-lhe favos vasios, póde acontecer que, por brusco abaixamento de temperatura, ellas não possam opercular os favos, o que fir com que o liquido desoperculado fermente, favorecendo o desenvolvimento da desinteria e. peor ainda, da terrivel loque a mais perigosa e desastrosa de todas as duenças que affligem a abelha.

Se á volta do lucal onde estão installadas as colmeias houver herva alta, ramos seceus ou fragmentos de madeira velha, convém rapar e retirar cuidadosamente tudo isso deixamdo o sólo completamente limpo, afin d'esses destroços varios não serem abrigo de ratus e musaranhos, que assaltam as colmeias e dão caça ás abellas quando estas, durante o inverno, se atrevem em dias de sol a sahir á procura de sustento: 
Sĩo sempre muito de temcr os mammiferos roedores e insectivoros e as aves insectivoras, durante o inverno, quando apertadas pcla fóme.

É por causa d'isto que é preciso não esquccer de diminuir a entrada das colmeias, de fórma a não ser possivel a passagem atrave\% ella dos pequeninos ratos (Wus musculus) e dos quasi microscopicos musaranhos (Sorex) quc são tão frequentes cntre nós.

Continua-se durante o mez de ontubro a dispôr o mel em frascos, a pòr em orlem o material apicola e rigia-se pela boa conservaçio da cèra colhida, que convóm preparar no dechrso do ne\% de noventbro.

\section{NOVEMBRO}

Comeşa o inverno, e, com elle, o curto periodo de tempo, entre nós, em que as abelhas ponco on nada trabalham, a não ser durante duas on tres loras nos riros dias de bom sol. É pleciso, pois, durante toda a hibernação, não bolir nas colmeias, para não provocar excitação no enxame, excitação sempre prejudicial na epocha dos frios.

Quando a chuva e a neve começam a calir em abundancia, é conveniente collocar, sobre a taboa que resuguarda a entrada, uma travessa de madeira maior e mais larga que a cxistente, mua tellua oll qualuper abrign que detemha a chinga e evite o amontoamento de liese junto da entrada, difficultando o alceesso d'all para o interior da colmeia.

Tumbem, havendo 17

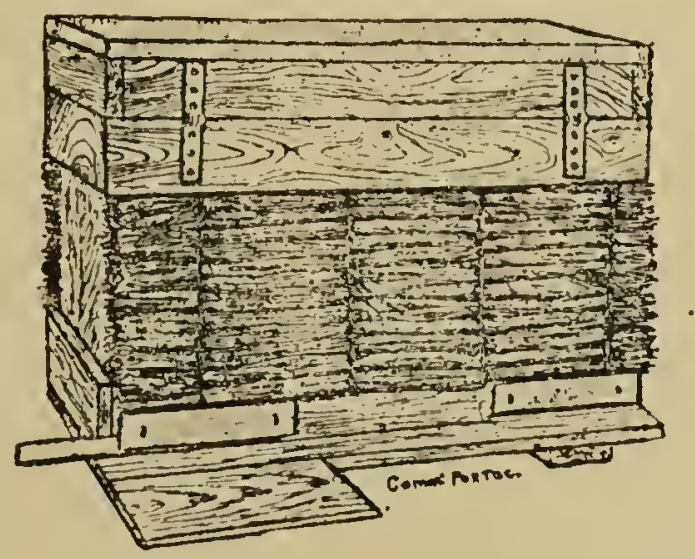

Colmeia Layens com shrigo de pulha para o inverno 
neve em exeesso, é util resguardar a eolmeia com uma cobertura de pallıa.

Se a exposição do colmeal fòr $11 \mathrm{~m}$ poueo ao norte, é indispensavel, por meio de tapamentos de madeira, palla ou ramos, de arrore, abrigar as colmeias dos ventos norte, tão desabridamente frios.

E, agora que as abelhas repousam, que não nos reclamam os eonstantes euidados dos mezes de plena aetiridade, devemos tratar de bem dispôr, para o mercado, os seus prodnetos, e preparar em espeeial a cêra, que tanto melhor e mais caro se vende quanto mais bem manipulada for.

No eapitulo especial dedicado á cèra, desenvolvidamente démos todas as informações relativas ao assumpto e para ellas clıamamos a attenção dos nossos leitores.

\section{DERE II BRO}

É o mez de completo descanço para o apicultor portugrue\%. Afóra o euidado de vigiar, nos dias de violento temporal, cue o vento não tombe as colmeias, nem a chuva entre n'ellas por alguma fenda, nem a neve se agglomere nas aberturas impedindo a ventilação, nada mais tem o apicultor que fazer n'este mez de pleno inverno para nós.

Se vir que o frio é intenso ou a chura constante, pórle. se ainda o não fez, para resguardar as colmeias, cobril-as cum uma cobertura de palha ou com uma folla de lata, sustentada por meio de pesarlas pedras ponsadas em cima.

O apieultor deve aproveitar os momentos de vagar; que agora tem, fabricando novas colmeias, preparando cêra moldada, limpando e pondo em boa ordem o material apicolia, e lendo as obras da especialidade que "habilitem a bem tratar das boas e santas abelhas. 


\section{Legrislayào apicola}

li resumida a nossa legislação apieola. 0 eodigo civil prituguez, diz apenas o seguinte respeito ás abellhas:

"Artigo 102." É licito a qualquer occupar os enxames que primeiro encontrar:

1. Não sendo perseguidos pelo dono da colmeia, de que houverem enxameado:

2. Não se achando pousados em predio do dono da mesma colmoia, on em qualquer edificin, on dentro de predio em que não seja permitticlo caçar.

$\$$ unich. Has se o enxaine fồ perseguido pelo dono da colmeia, serii (1) proprietario do predio obrigado a permittir-lhe que o recollia, oll a pagar-lhe o valor d'elle.

A ultima lei da eontribuição industrial, na tabella $A$, que comprehende industrias, profissões, artes ou officios, sobre que recíhem taxas fixils ou por indieadores especiaes, que nâo prodem tazer gremio, occupa-se assim dos que tratam, quer das abellais, quer dos produetos cerificos do utilissimo inseeto:

('êra (lagar de espremer):

Culla prensa on vara. . . . . . tsukn

Colmeins (dono on rendeiro de):

Até trinta colmeias nada paga. De trinta e uma a norenta. . . . . . . $8(k)$

Carla colneia a mais. . . . . . 100 
É excessiva a contribuição lançada sobre cada prensa ou rara de espremer cêra, assim como o não é insignificante, como parece á primeira vista, a contribuição de oitocentos reis sobre aquelles que possuem de trinta e uma a noventa colmeias, e de cem reis por cada uma acima d'aquella quantidade.

O fisco devia ter em vista a irregularissima producção das colmeias de cortiça, as unicas, infelizmente, ainda geralmente adoptadas no paiz, e lembrar-se que o imposto de cem reis sobre carla colmeia acima de noventa, vae obstar, por completo, ao desenrolvimento de uma industria tão auxiliar da lavoura sob todos os diversos pontos de vista.

Os nossos legisladores, em logar de pensarem em tributar tão pouco amoravelmente a apicultura, deriam antes tratar de fomentar o seu desenvolvimento e de cuidadosanente regular a sua cultura.

Assin as abelhas, excepto nos terrenos alugarlos, deviam ser cousideradas bens immoveis isentos de torla e qualquer penhora.

Tambem deviam ser castigados com sererissinas penas fixas e especiaes, não só os que roubassem colnteias, mas tambem os que fossem perturbar as abelhas no seu trabalho utilissimo.

Urge que seja prohibido, a nĩo sel por extraordinario caso de força maior, a rleslocação de colmeias fóla dos mezes de dezembro, janeiro e ferereiro. O facto do proprietario de um enxame o não seguir não dere, igualmente, ser motivo de perder o direito a elle como o nosso codigo civil parece indicar:

Muitas vezes acontece o enxame saluir inesperadamente, scm o proprietario do colmeal dar d'isso fé, não podendo purtanto ir atraz d'elle com o costumado berreiro das nussas aldeias. É por isso de torla a justiça a garantia da posse do enxame sempre que o proprietario prove claramente ter elle sahido do seu colmeal, quer por meio de testemunhas, quer por meio das proprias abelhas, o que ć facilimo. 
Fóra do caso da raça das abelhas ser unica, e por conseguinte differente da da localidade, o apicultor póde, no dia da salida do sel enxame ou no segunte, provar, ao encontral-o installado en casa de qualquer visinho, se elle the pertence ou não, cobrindo $n$ grupo de abelhas com farinha muito fina e fazendo retirar a colmeia nora do logar onde estava para outro muito desviado.

As abellias enfarinhadas não encontrando a nova habitação, depois de alguns minutos de hesitação, voltam para a colmeia antiga, donde enxamearam e onde é facil de verificar a sua entrada attendendo a que récm completamente cobertas da farinha que the foi deitada, afim de irrefutavelmente mostraren qual a sua orjgem, e portanto qual o seu dono.

A proprierlade das abelhas deve sempre ser, por torlas as fórmas, cuidadosamente garantida como o ć a de ontro qualquer animal domestico.

Para cvitar as frequentes aggressões das abelhas aos animaes domesticos e ao homem, não devia ser permittido na nossa legislação que fossem installadas colmeias á beira de estradas e caminhos publicos, nem junto de propriedade visinlaa com casas de habitação, e roltarlas rle fórma que fizessem constante caminho atrarez ella. 


\section{A flora apicola-Plantas a cultivar para a produccào do pollen e do nectar}

Antes de ser installado um colmeal em uma lada região, ó preciso estudar cuidadosamente a flora local e rêr, em face d'ella, o numero de colmeias que, alli pódem vantajosamente subsistir. Conrém que, em um raio de um kilometro á rolta do colmeal, as abelhas encontrem alimentação sufficiente, pois, tendo de a ir procurar mais longe, não só estão sujeitas a numerosos perigos e accidentes, mas tamben a colheita é muito menor, em rista do largo espaço de tempo perdido nas diarias viagens.

O mais bem situado dos colmeaes é aquelle em, que, a distancias não superiores a um kilometro, as abelhas tenham planicie e monte para pastagem, risto que assim, quando o nectar e o pollen.escassêa nos prados, existe em abundancia nos montes e vice-rersa.

0 apicultor não deve tambem esquecer-se de plantar e semear á volta do colmeal arvores e plantas boas productoras de nectar e de pollen, e substituir a cultura de forragens que segregam pouco nectar, por outras que, possuindo a mesma importancia alimentar para o gado, são comtudo muito superiores para sustento das abelhas.

O grande apicultor fruncez snr. G. de Layens deu no «Bulletin de la Société d'apiculture de l'Aube» a seguinte lista das plantas melliferas rirazes que rebentam e se repro- 
duzem espontaneamente, sem sementeiras annuaes e que, portanto, conrém propagar á rolta dos colmeaes:

Fevereiro e Mare, - Corylus avellana, aveleira.

Marẹ e Alnil. - Vinca minor, pervinca (março, abril e main).Arer oumulifolium, bordo.-Rosmarimus officinalis, rosmaninho.-Pulmonarin officinalis, pulmonaria. - Salix caproca, fragilis. etc., os salgueiros em geral.

Abril e Maio. - Pulmonaria tuberosa, pulmonaria tnberosa. - Cytisus lahumum, falso ebano.-Bunium carri, herva doce on anis dos l'osges. - Prumus spimosn. espinheiro negro. - Populus bulsomifern. 1,alsameiro.

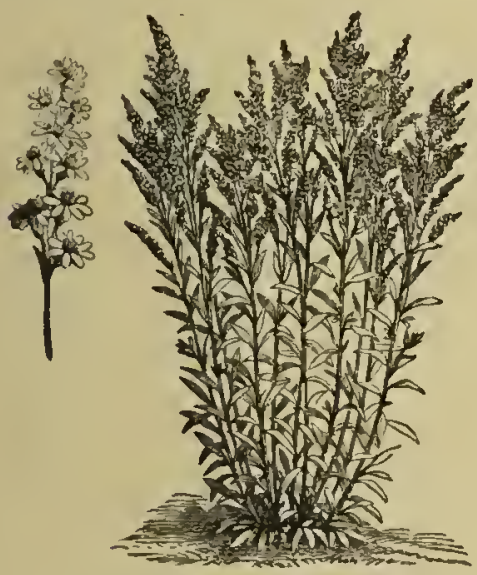

Sulvia pretensis

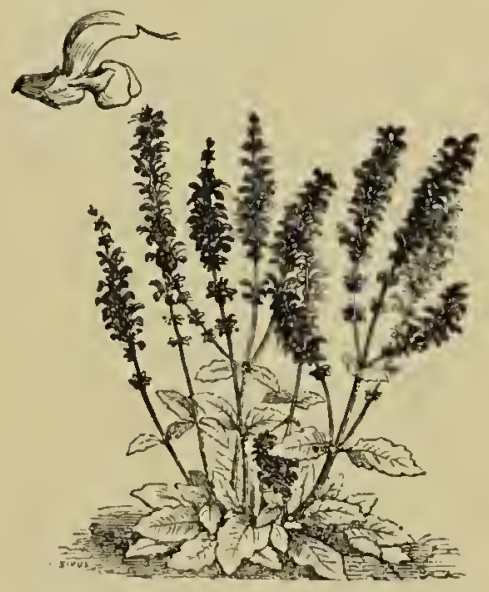

Solidago virga abren

Maio e Junho, - Salvia protensis. salva brava. - Euchium mulgare, viperina. - Cymoylossum officiuale, lingina de cão.-Cynoglossum nonInmum.-Pobinia pseudo acacia. neaeia. - Lalicago lupulina, lupulo.-Trifolium montanum, trevo braneo. - Ligustrum vulgare, alfeneiro. l'imuinella magua. anis de follas grandes. - Asphodelus allus, aspliodelo branco. - Asphodelus fistulosos. - Berberis inlgaris, berberia. Arep plrtamovides, falso cyeomoro.-Acer cautuestre, bordo.-Lonicera raprifolium, madresilva dos jardins. - Sorbus terminalis, Jodĩo. - Sorlus. alin, marmeleiro bravo. - Sorbus auruparia, sorveira.-Ciatorgnes oryacuntha. pilriteiro. - Cristus umbellatus. - Cistus medon.

Junho e Julho. - Salvia officinalis, salva officinal.-Lycium barbatum.-Phytemma orbirulare, raponcio. - Phutenna spicatum. - Solidago virya aurea. virga-iurea. - Cistus laudnuiferns. - Cistus Honspeliensis. 


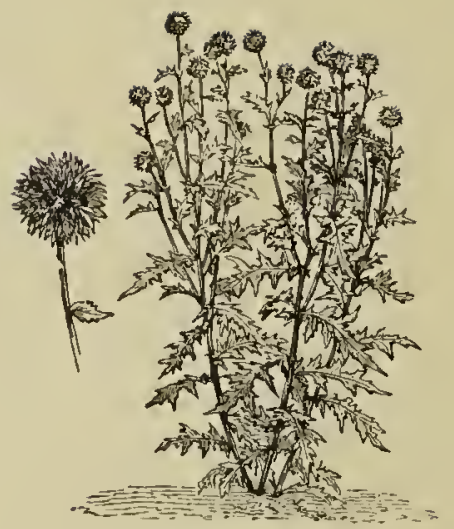

Echinops ritro

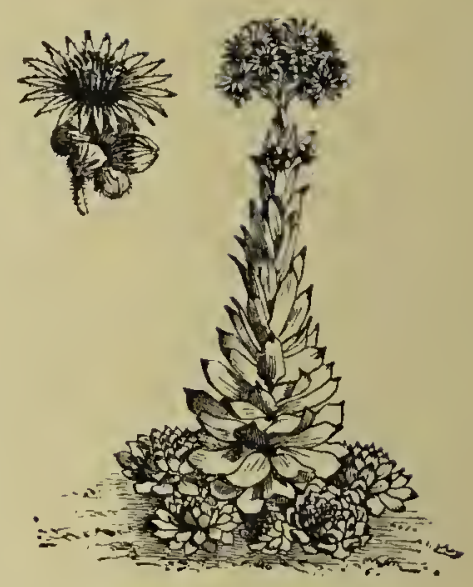

Sempervinum tectorum

Julho e Agosto. - Salvia rerticillota, salva verticillada. - Lacandula spica. alfazema. - Mentha rotundifolia, hortelã crespa. - Origamum vulgare, nangerona. - Thymms serpillum, serpào. - Satureia montana. segurelha.-Melissa officinalis, herva cidreira.-Hyssopus officinalis, hyssopo.-Veronica spicata, veronica. - Veronica salicifolia. - Veronica rirginica. - Pastinaca sativa, pastinaca. - Echinops ritro. - Eprilobium spicatum. - Epilobium rosmarinifolium. - Sentpevvirum tectorum, saião dos telhados. - Sempervivum montamum.

Agosto e Setembro. - Aster amellus, aster.-Aster oppositifolius. - Aster bellidiastrum. - Aster Tripolum. - Ceratonica saliqua, alfarrobeira.»

Na primavera, quando as arrores principiam de rebentar, quasi todas segregam enorme quantidade de nectar, que as abelhas cuidadosamente recolhem, e com o qual fabricam um mel fino e perfumado.

Em seguida véem as flòres dos milhares de regetaes diversos, as quaes, to-

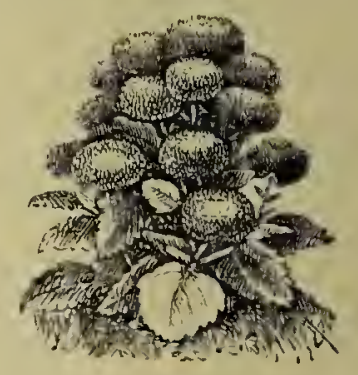

Shakespeare Aster das, mais ou menos abundantemente, dão nectar ou pollen, ou ambas as substancias no mesmo tempo.

Depois que Dzerzon descobriu que a farinha dos cereaes póde perfeitamente substituir o pollen na alimentação das abelhas, não convém cultivar, apicolamente fallando, senão as plantas grandes productoras de pollen e de mel. 


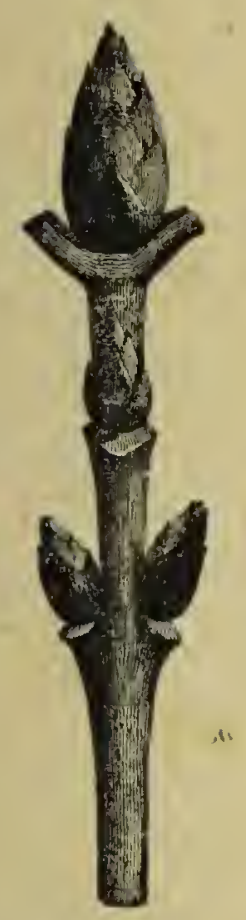

(Homos d'arvores

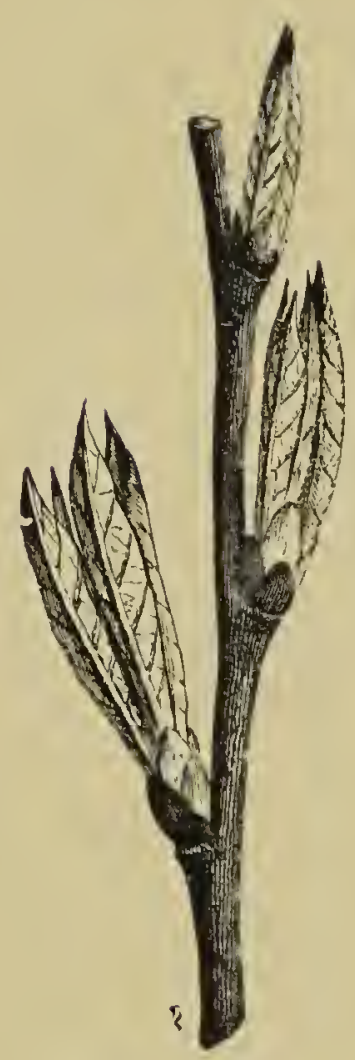

Rebentos a'arvores

o dr. Conrad de Muelennere classifica assim, pela ordem de superioridarle e valor commercial, o mel das diversas plantas:

1." O mel do Trevo encaruado (Trifolium incurnatum).

2.0 0 mel do Sanfeno (Onobrychis satira) e do Trevo (Trifolium mppens:.

$33^{\circ} 0$ mel das arvores fruetiferas (Macieiras e Ameixieiras para mel, e Pereiras e Cerejeiras para mel e pollen).

4. ${ }^{\circ}$ O mel de Colza branco é exeellente mas de sabor oleaginoso.

$5^{\circ} \quad 0$ mel ilos Prulos ou das Labindus aromaticas ('Tomilho, Hyssope, Serralha, Mangerona. Alfazema, Carvalhinha, ete.) e de certas Boragineas, Renmenlaceas e Caryophlyllatrs.s ex excellente e elaro.

6." O mel da Aeneia é excellente. É, segundo Voiruot, o mel das damas.

7.0 O mel to 'Trigo mouriseo é escuro e de sabor especial o agradavel. Excellente para o fabrieo do pão de especie, 

neris:

8. 0 mel da Tilia é um mel hygienico e de um sabor sui-ge-

9." 0 mel do Taraxaco e da Chicoria é ordinario e renenoso.

10. O mel do Pilriteiro é nocivo, cansanto ás abellas a toenca conhrecida pela designação de mal de maio.

11." O mel da Estera, escuro e pegajoso, é de qualidade inferior.

12." O mel do buxo (Burus sempervirens) é hom, mas de cirr mito carregada."

A maior parte das nossas estradas

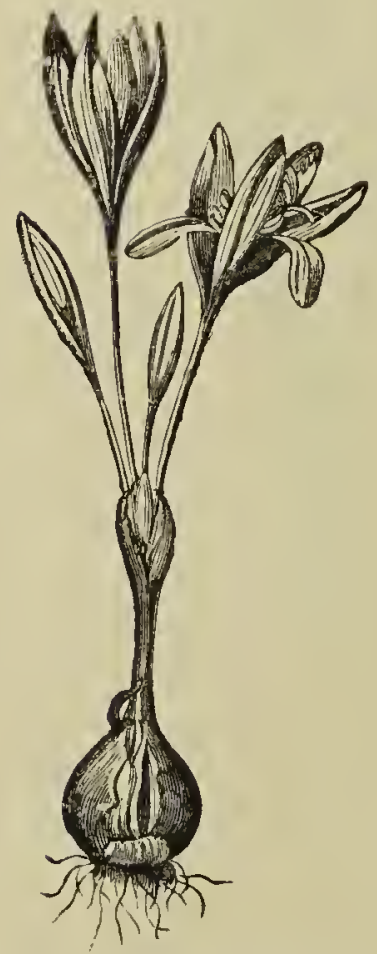

crocus on Açafrio publicas estão despidas de vegetação. Vestil-as com essencias florestaes ou fructiferas adequadas á região seria uma medida de alto valor, que largamente concorreria para o augmento da riqueza agricola do paiz.

Sob o ponto de rista apicola as melhores essencias a aproveitar para as estradas e cantinhos publicos são as segnintes :

Pyrus merlus. Macieira; familia das Rosacers. A macieira reclama sólo rico e $\mathrm{um}$ pouco luumido; porém a humidade em excesso, principalmente a agua encharcada, é-llıe muito nociva. A macieira, por causa das suas raizes, que lavram muito, deve ser plantada ponco funda. É necessario dispôr as arvores a dez ou doze metros de distancia umas das outras, afim de se desenvolverem bem. Nas estradas pódem ser cultivadas as macieiras de fructo para mesa, on melhor de fructo para seccar, para cidra ou distillaçĩo.

Pyrus communis. Pereira; familia das rosaceas. Emquanto a macieira requer terrenos humidos a pereira dá-se admiravelmente em terrenos seccos. Para estradas conrém sempre escolher as variedades de crescimento rapido.

Prumus Padus, da familia das Rosaceas. Desenvolve-se 
perfcitamente mus terrenos seccos, calcareos e mesmo pedregosos.

Quercus Robur, la famitia das Cupulifercts. Desenvolro-se bem nos terrenos abrigados onde não esteja sujeito nem a frios intensos nem a calores excessivos.

Tilins, argentea, nacrophylla peudula, americana e platyplyylla, da familia das Tillicreas. Desenvolvem-se almiravehmente entre nós nos terrenos arenosos, profundos e ricos em hunus. Convém nas avenidas plantar alternadancnte as diversas rariedades de tilia, de fórma á forescencia se estender de maio a jullio.

Aescnlus lippoeastamum. Castanheiro da India; da familia das Sopiudaceas. O' castanlıciro da India rechama sólo fertil; não se dá bem nem en terreno calcareo nem em terreno argiloso.

Aesculus rubra. Castanheiro da India. Este lindo castanheiro da India deve ser plantado juntamente com a especic acima indicarla, por causa do effeito de contraste, por isso que o hippocastamm produz cachos de flòres brancas, emquanto o rubra os dá de um lindo rosa-vivo. Ambos florescem de maio a juuho.

Rabimu psento-ucuciu. Acacia branca ou Acacia commum; da famitia das rupiliomacens. Reclama sólos arenosns e catcareos; floresce de maio a junho.

Acer psemdo-platame; da familia das sropinducers. Dá-sc muito bem em terreno lcre, em declive; floresce de abril a maio.

Clmus compestris. Ulmeiro, Negrilho; da familia das Ulmuceus. É mma arvorc que se desenvolve admitavehucnte 110 nosso paiz, sobretudo nos terrenos argito-calcareos $u m$ ponco humidos. Floresce de março a abril.

Populus. As diversas variedades de Cloupo, da familia das Sralicircas, dão-se magnificamente entre nós em torlos os terrcuos leves, humidos e profundos. São bastaute melliferos, e ha alguns como, por exemplo, o Populos Balsamea que fornecem propolis em abundancia. 
Pódem ser utilisados entre nús com vantagem os seguintes Populos:

Populus alba, Alamo branco. Clioupo branco, Faia Branca. Poyulus cauadeusió, Clioupo do Canadá.

Populus aurea, Choupo de folla amarella.

Populus fastigiata, Choupo pyramidal.

Populus tremula, Faia preta, Alama lybico.

Populus nigra, Choupo negro.

Populus monilifera.

Populus balsamea.

Os Salix ou Choróes da familia das Sreficineres.

Os salgueiros vivem bem nas margens dos cursos de agna, lagos, etc., emfim em todos os sólos humidos, mesmo em excesso. Pela sua precoce florescencia são das mellores arrores para a apicultura.

Devemos utilisar os:

Sulix balyglonica.

Salix argeuter.

Salix capraca.

Salix purpurea.

Salix rosmarinifolire.

Salix vitelina.

Salix viminalis.

Salix de Hollanda.

A Sophora japonica, arvore grande de tronco direito, ramos pendentes, follıas verde claro, e flòres em panicula de um branco amarellado, é de primeira ordem para pasto das abelhas, assim como as suas variedades de fol. rar e perdula.

Pelo paiz fóra ha, quer nos taludes das linbas ferreas, quer nos das estradas publicas, quer nos terrenos particulares, largas extensões improductivas pela aridez e magreza do sólo, que podiam ser utilmente aproveitadas cultivando n'elles plantas melliferas proprias, que, fixando economicamente os taludes ou terrenos en declive, dariam pasto a largo numero de colmeias com abellias.

As melhores a mais aproveitareis são as seguintes: 
Beiberis vulyaris atropurpurea que floresee de abril a maio. Caryoptris Mustacanthus que floresee de junho a outubro. Chrumacerasus Beramgeri que florosce na primavera. Coluter arborescens que floresce de maio a jullo. Coronille Emerus que floresce do março a junho. Dentrin gracilis que floresce em abril o maio. Eronymus Europoeus que floresce de abril a junho. Gemistr Scoparia que floresee de abril a junho. Geuistre albre que floresee do abril a junho.

Gruista Tinctoria que floresee de abril a junho.

Hipmophä. Rhammoüles que floresee de março a maio.

Lignstrum mulgrue que floresce de maio a jullo.

Ligustrine anumense que floresee de maio a julloo.

Ribes amemu que floresce na primavera.

Ribes alpimum que floresce na primavera.

rubus Cauadensis que floresce na primavera.

Syumplericrupus racemosus que floresce de maio a outubro. Sylostcum Philomele que floresee en jumho.

Os logares onde la agglomerados de terra e pedras, quer natmlaes. quer artificines, pódem sor vestidos oom varias plantas lenlosas e horbaceas que se dĩo n'aquella especie de terreno mais ou menos secoo, e que, oobrindo-os, muito os embellesam, formeeendo a mesmo tempo $11 \mathrm{~m}$ bom pasto ís abellus.

As principaos são:

Familia das Apocynocers:

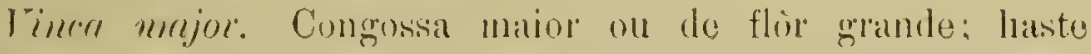
rasteira, follats lanuçinosits, de le tum puro azul, que desabrocham em abril o maio.

rincre minor. Congossia monor, ou do flôr pequena, on violeta dos feiticeiros. Haste fina, dira o rastoina, folhas remles e flores de coloride azul, sustentidas em peduneulos mais comprirlos que on clas follas. Floresce de maręo a maio. Ha ruma linda viriedade de follagem estriada de branco on anarello.

rinee roseu. Congossa rosa on do Marlagascar. Fullass ublongas e flòres còr de rosa que desabroolatm de junho a setembro. 


\section{Familia das Labiadas :}

Thymus vulgaris e Thymus tomentose. Tomilho. Flòes reunidas formando geralmente espiga. São plantas extraurdinariamente melliferas.

D'entre as plantas herbaceas, melliferas, que pódem sel utilisadas para o fim especial de que tratamos, salientam-se as seguintes:

Arabis Alpina e Albida; Crucifera, de flôres de um branco puro.

Asclepias syriaca: Asclepiaden, de flôres rosa claro muito odoriferas.

Betonica grandiflora; Labiada, de flòr violeta.

Campamula rotundifolia; Campamulacea, de flòres de còr azul ou branco conforme a variedade.

Comrolvmlus Seprimm; Comvolvulncea, de flôres brancas.

Iracocephalum; Labiada, le flôres de côr azul e rosa.

Fragariu indica; Rosrecer. É uma especie de morango bravo, de flòres amarellas e fructo não comestivel vermelho carregado.

Hyssopus officinatis; Lalviada, de flòres en espiga, e de còr azul.

Limaria Cymbalario: Scrophulariacer, de flôres de $11 m$ lilaz claro.

Mentha rotmulifolia; Labiada, com espigas de cồ azul.

I'hytenma spicatmm; Campomulacen, de flôres azul escuro.

Rudbeclacia speciosa; Composta, de flòres antarello laranja on amarello claro.

Ruta Gracenlens; Rutacen, de flòres amarellas.

Semperrirmm tectormm; Crassulacea. de flôres de um amarello claro.

Gypsophila repens muito rustica e apreciada pelas abelhas assim como as variadas clematis, especialmente as clematis riticclla de flòres violeta e a clematis vitalba de flôres branca.

As plantas excessivanente melliferas segregam nectar durante todo o tenipo da sua florescencia, de modo que as abelhas encontram n'ellas sempre o mesmo pasto durante dias e dias. 
$\Lambda$ abundancia de nectar nas flòres é proporciomal ao tempo: estando este humido e quente a secreção é abundante, emquanto que diminne com o frio e a secura atmospherica.

As plantas que, nas quatro estações do anno, são, entre nós, preferidas polas abellıas para pasto, indicamol-as, para facilidade de cultura, agruparlas na estaçăo em que são ntilisadas:

Fim do inremo. A Aveleira, o Pilriteiro, a Amendoeira, o Pecegueiro, o Damasqueiro, a Camellia e a Acacia dão muito pollen: o Salgueiro, o Olmo, o Choupo e a Faia fornecem pollen, mel e propolis; o Codeço, a Grosellieira, o Tojo, a Giésta, o Buxo, o Alecrim, a Violeta, os Amoresperfeitos, o Goiro, a Glycinia e o Morrião, pollen e mel.

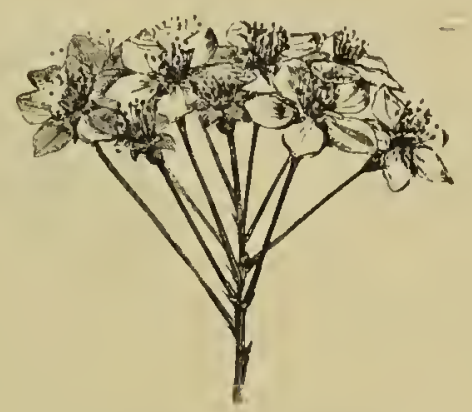

Florescencia da cerejeir'a

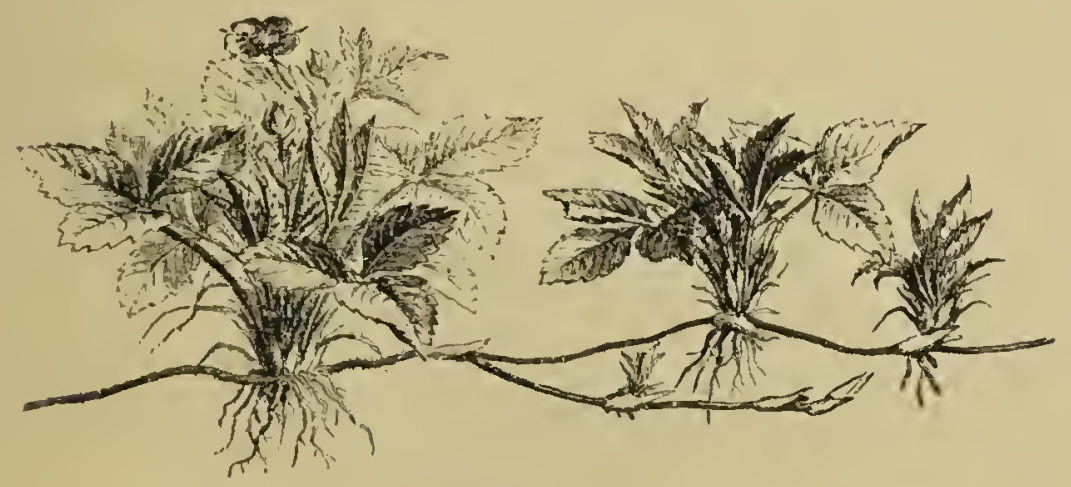

Morangueiro

Primrreren. Torlas as arvores que entio se restem de flores, quer sejam rle fructo, quer de ornamento, sogregan en maior ou menor quantidale pollen e mel. São bons productures a Ameixieira, o Abrunheiro, a Pereira, a Macieira, a Cerejeira, o Marmeleiro, o Carvalho, o Azinheiro, o Freixo, a Betula, o Bordo, o Cycomoro, a Sorreira, etc.

As Tulipas, Narcisos. Crocus, Amaryllis, Gladiolos, Jacin- 


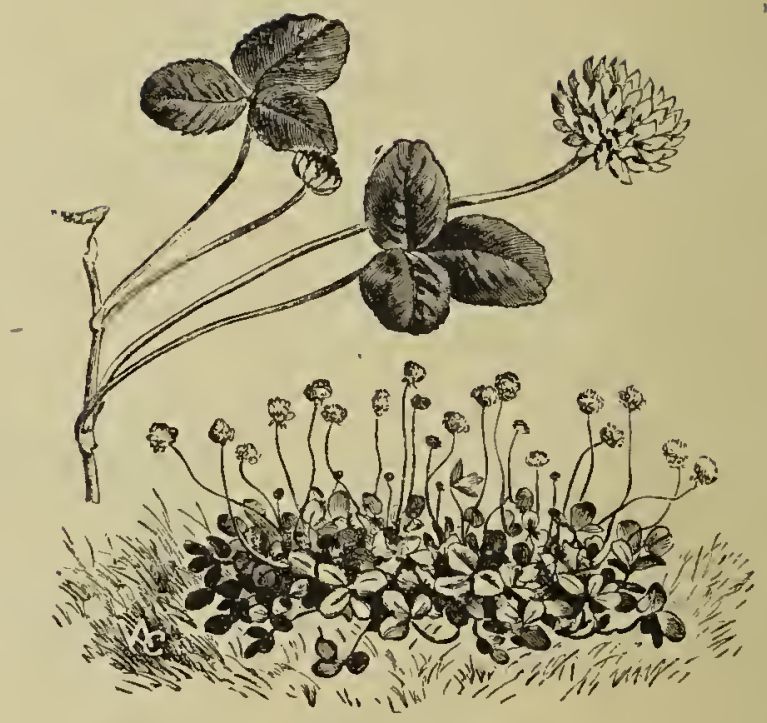

Trevo branco

thos, Berberis. Favas, Ervilhas, Eirvilhaca, Nabos, Conves, Culza, Morangueiros, Minonete on Reseda, Rosas, Aquilegias, etc., dão mel e pollen.

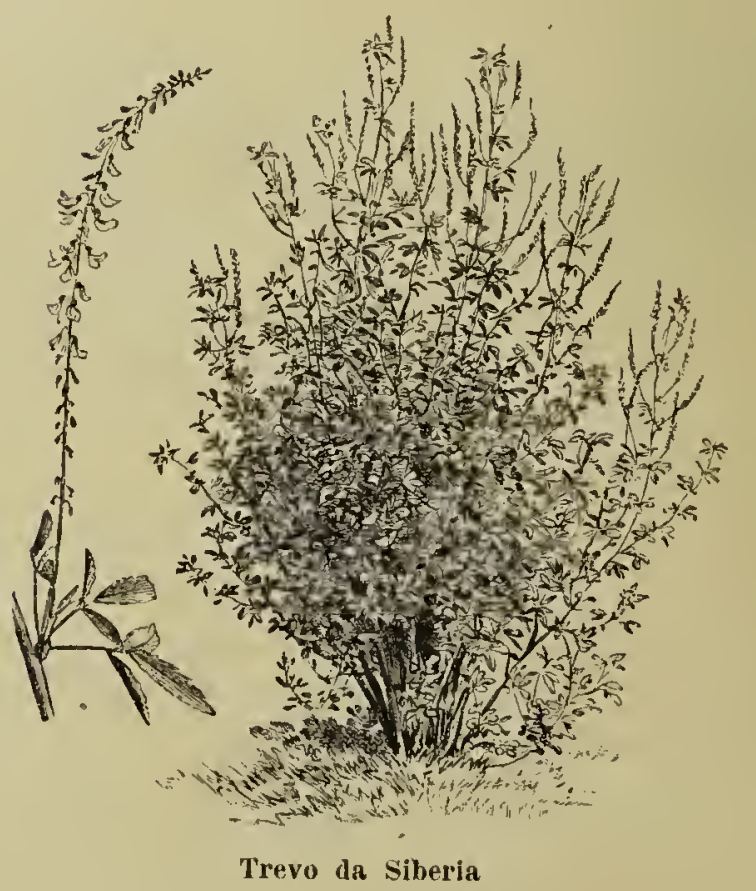


Produzem mel a Sylindra, Arando, Trevo, Sanfeno ou Espazeta, Ervilhaca ou Ferrã, as Lagrimas de Job (Fuchsias), etc.

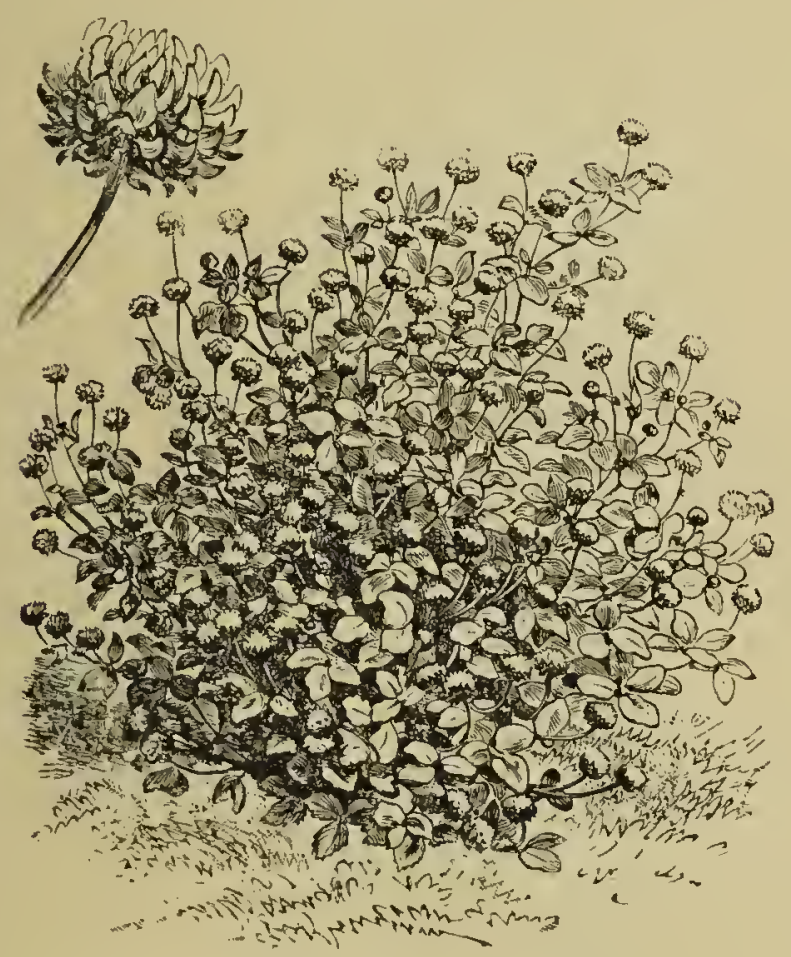

Trevo liybrido ou d'Alsika

As diversas variedades de Trevo e o Sanfeno são plantas preciosas para as abelhas, pois fornecem-llie durante mezes, o

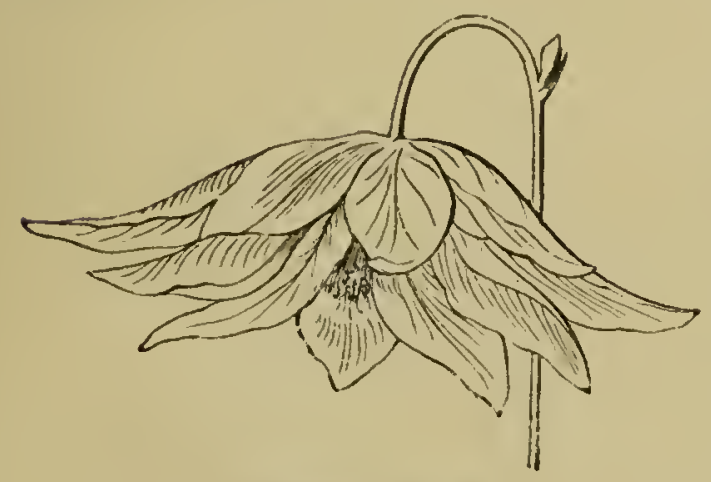

18

em enorme abundancia, $11 m$ bello e aromatico mel, sendo an mesmo tempo forragens de primeira ordem para o gado, quer seccas quer rerdes. Convém espalial-as por toda a parte; semeal-as nos prados, nas orlas das estradas, nos taludes das 
vias ferreas, emfim pôl-as o mais possivel ao alcance das abelhas.

As Fuchsias, mais rulgarmente conliecidas pelo nome de Lagrimas de Job, e Brincos de princeza, essas plantas arbores-

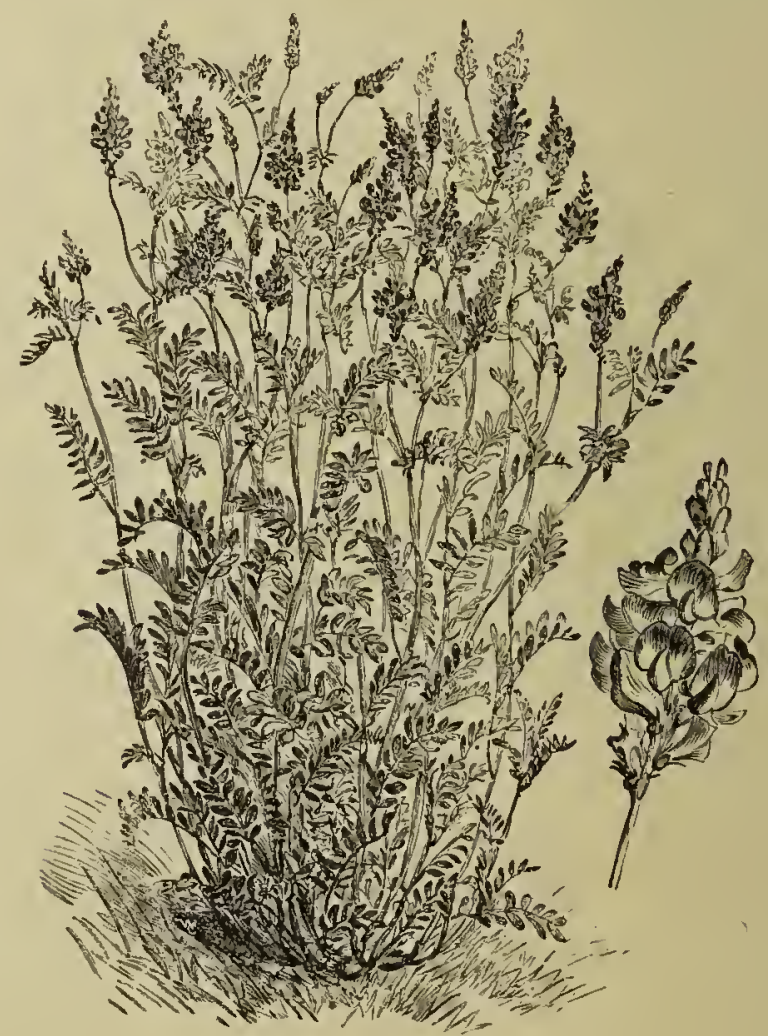

Sanfeno commum

centes que todos conhecem, pelas flòres lindissimas que as cobrem, não só dão algum pollen mas tambem segregam mina extraordinaria quantidade de mel finissimo.

Verão. No principio do verão, temos em primeiro logar a Tilia.

A Tilia é a arrore que fornece maior quantidade de mel ás abelhas, mel justamente considerado o melhor de todos para mesa, pois conserva em alto grau o perfume das flôres donde 


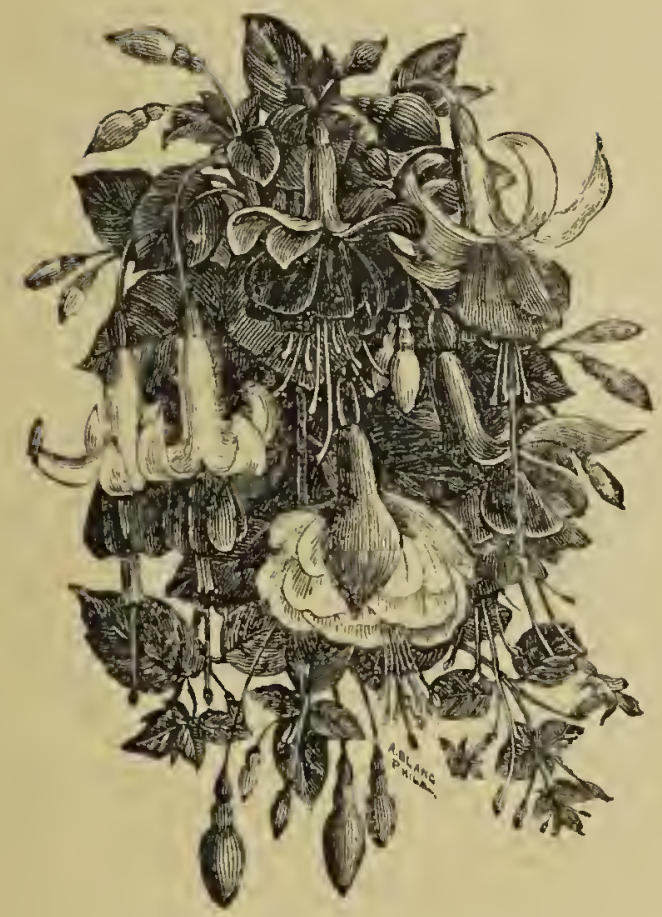

Furlisiak

é collido, e crestallisa facilmente. Até nesta boa arvore ntil nãu sĩu só as flôres que dão mel; as proprias follas segregam

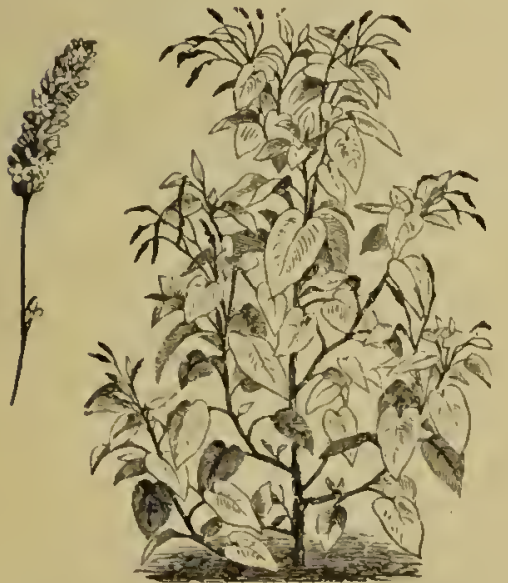

polygonum orientale

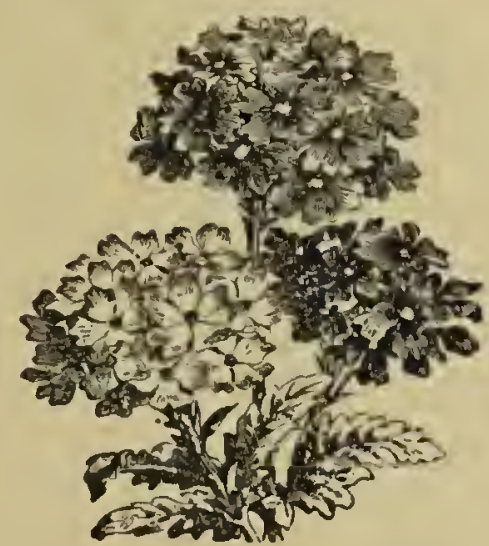

Verbena hybrida 


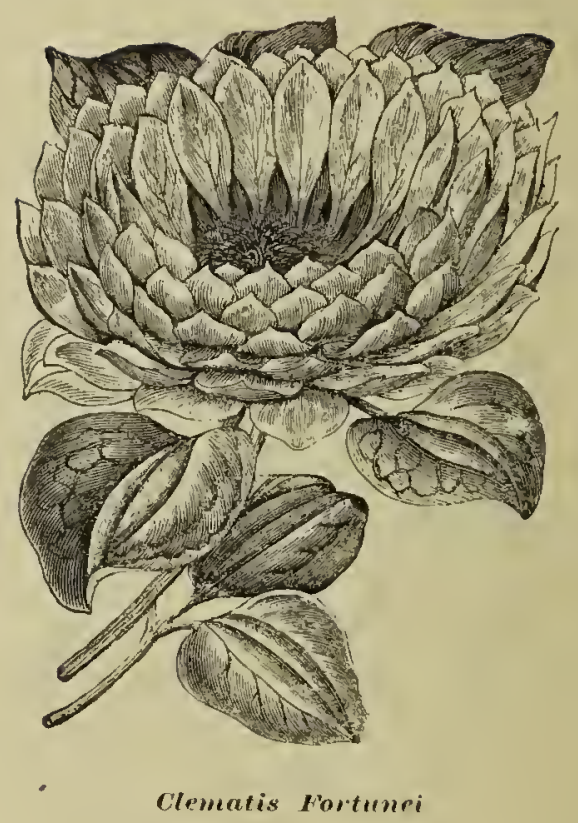

um suceo assucarado que as abelhas tambem recolhem com todo o cuidado.

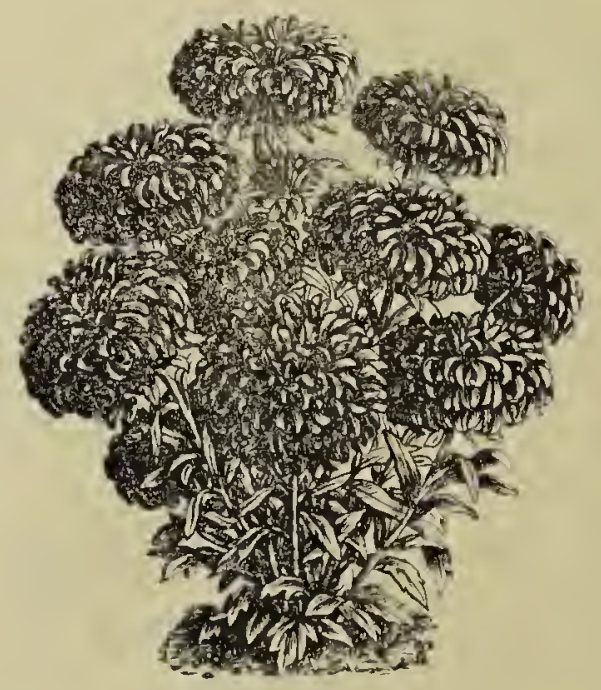

Rainla Margarida

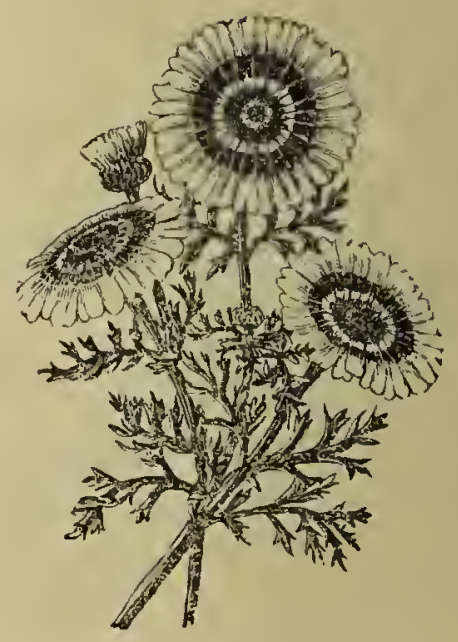

Chrysonthemmut carinutum

Uma só Tilia, em pleno desenvolrimento, e com uma boa florescencia, dá mel para tres colmeias moveis fórtes. 
Um apicultor celebre o snr. G. Doolitle, referindo-se ao ralor mellifero da Tilia escrereu no Consemateu des abcilles o seguinte:

Creio que a Tilin é a arrore d'este inundo que dá mais mel.

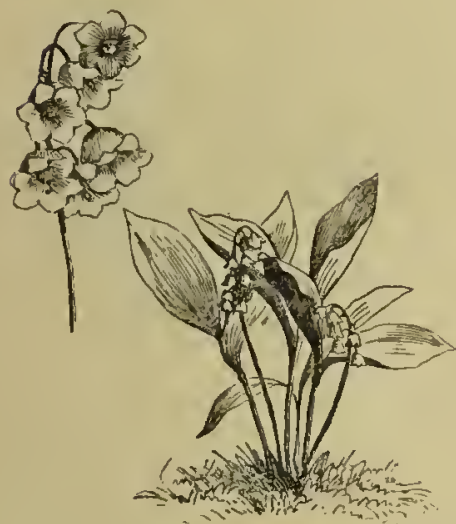

Lirio convalle

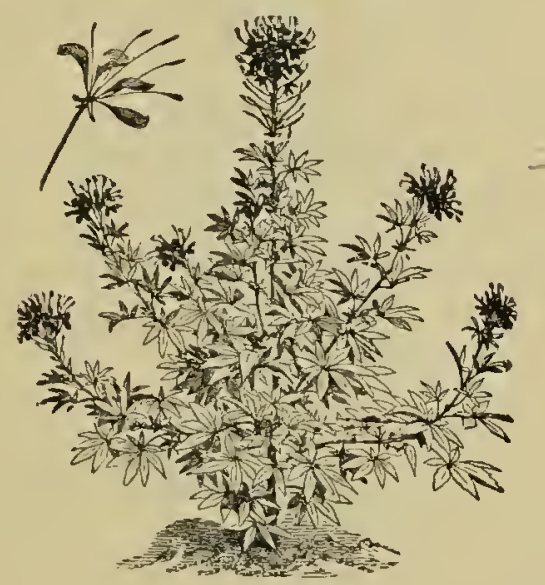

Cleome pungens

Nĩn me recordo que pessoa alguma tenha fallado até hoje de ontra planta que forneça em média, a cada colonia, dez kilos por dia, durante trinta e oito dias seguidos. Gallmpen certifica isto, e ell posso

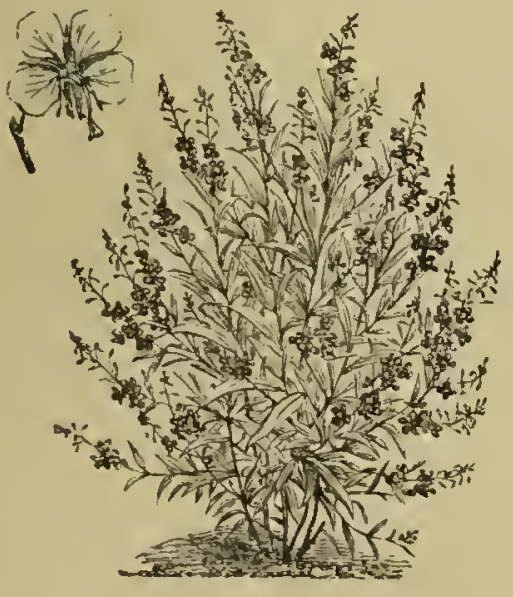

Epilobium spiratum

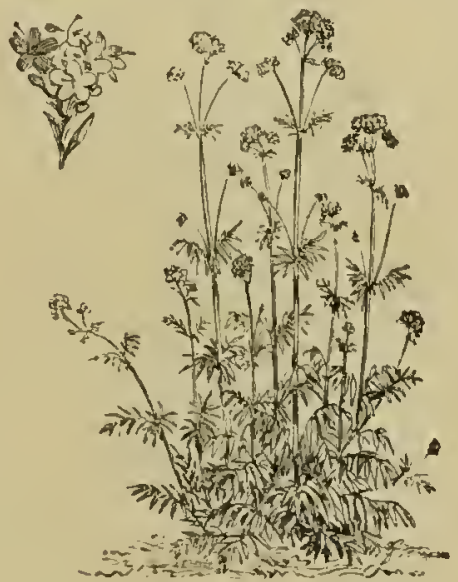

rateriande officinalis

assererar que uma das minhas colmeias me dell esta média durante dez dias segnidos. 


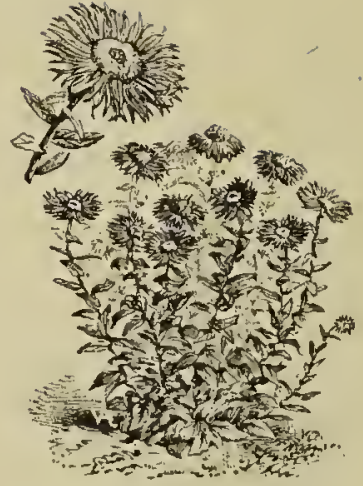

Inula glandulosa

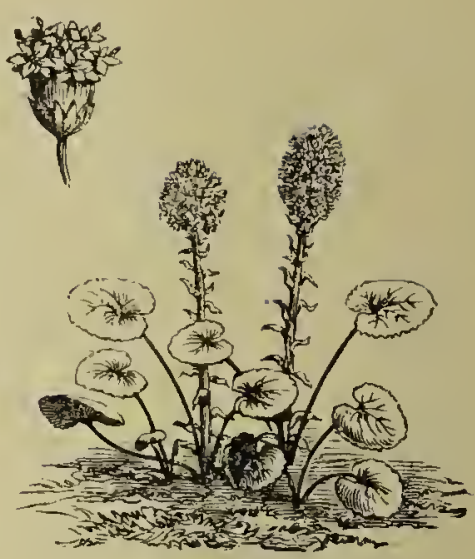

Tussilugo fragroms

Eim tres dias verifiquei uma colleita de trinta e tres kilos.

Examinando as minhas notas de ha doze annos para cá, relativas ao producto das minhas abelhas, rejo que só a Tilia me cá, cadia anno, uma média de trinta e cinco kilos ein favos, pol' colmeia. A mais fraca prodncęão foi de vinte e dous kilos e a maior foi de sessenta.

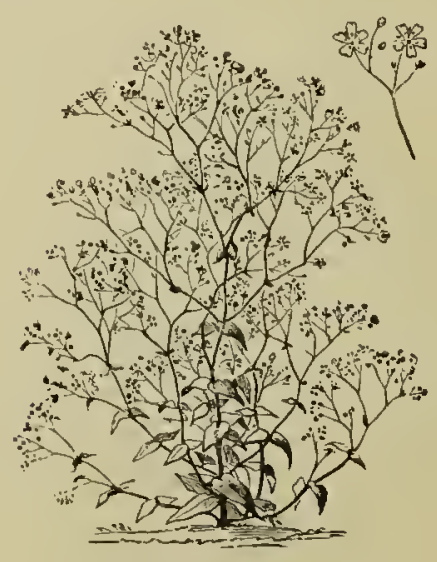

Lobelire cardinalis

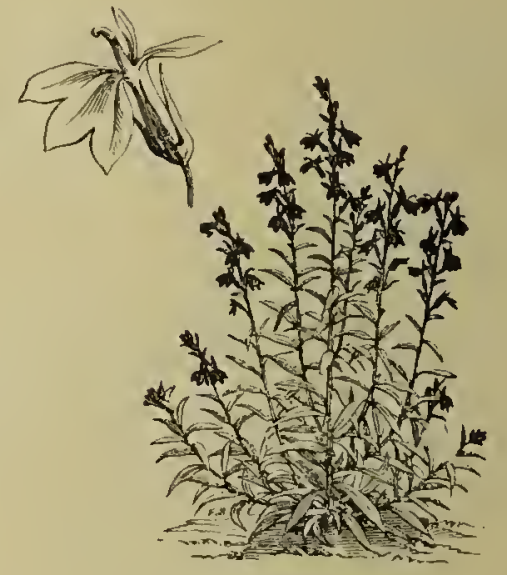

Gypsoptuita elegans

Convém que a plantação de Tilias destinadas a pasto das abelhas, seja feita com as diversas rariedades da magnifica arrore, de mistura, pois não desabrochando as suas aromaticas flôres, todas ao mesmo tempo, maior e mais abundante é a colheita do mel. 
A Sopleora japonica, uma arvore grande, de ramos pendentes, produz flôres de um branco amarellado, dispostas em paniculas, que sĩo de primeira ordem para alimentação das abelhas, a quem fornecem basta quantidade de pollen e mel.

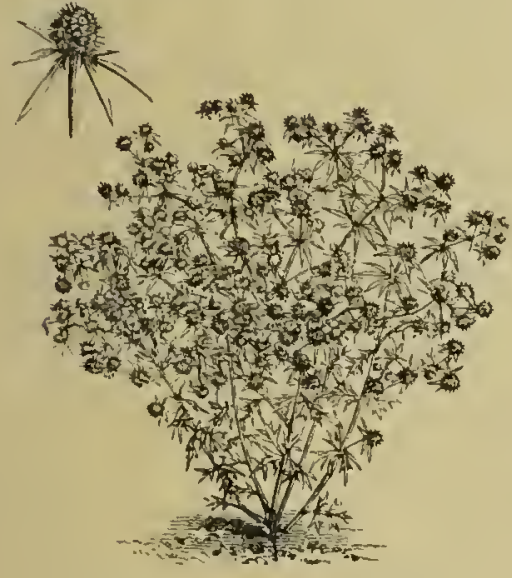

Eryngium alpinum

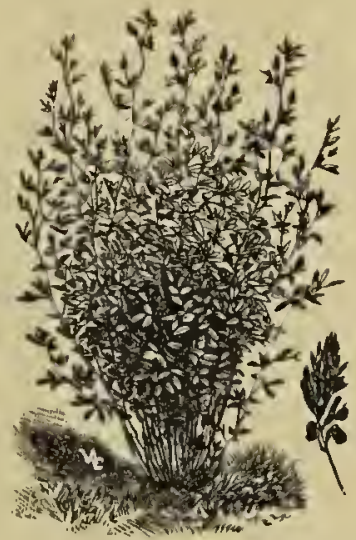

Luzerua da Provenga

Tambem dão muito pollen e mel o Encalipto, o Ailantho, o Castanheiro, o Pinheiro, o Liriontentron tulipifera ou Arvore do ponto, etc.

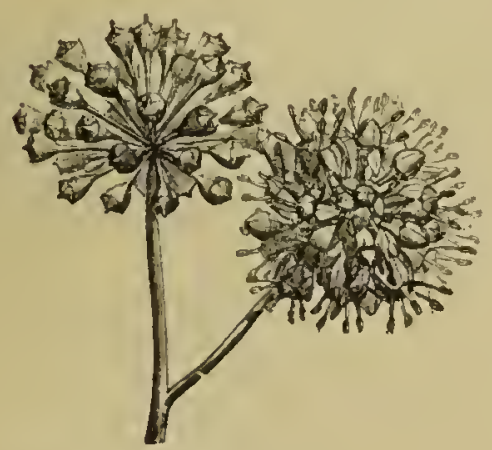

Florescencia da hera

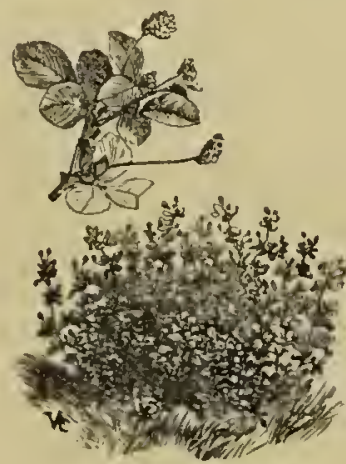

Inzerna Inpulina

A Mostarda, a Abobora, o Pepino, o Melĩo, a Melancia, o Tomilho, o Serpão, a Salva, a Alfizema, a Herra-Cidreira, as Silras, o Eronymo, as Chagas, os Ruscos, as Clematis, as Lan- 


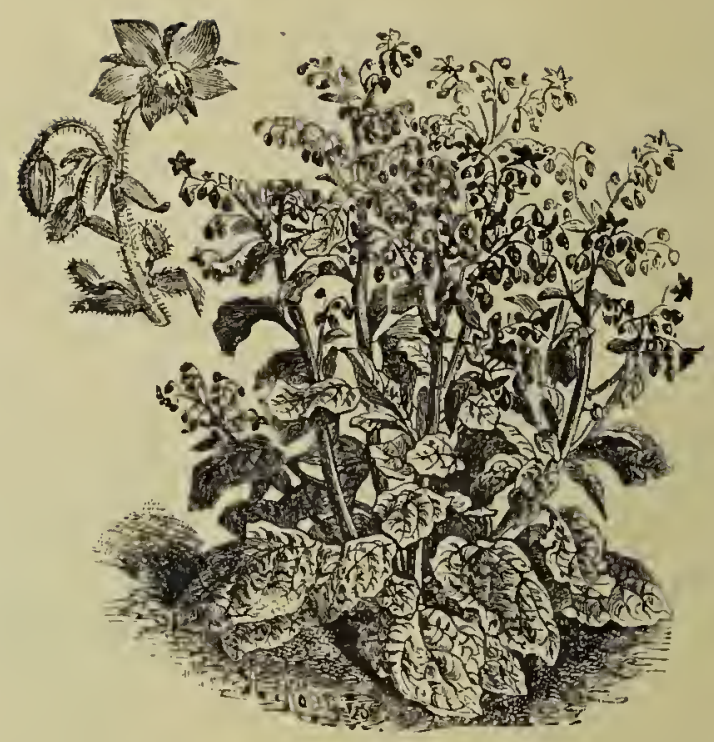

Borragem

tanas, as Spiraea, as Rainhas Margaridas, os Polygonum, as Verbenas, o Lirio conralle, o Cleone, os Epilobiums, Telerianas, Inulas, Tussilago, Iris, Lilios, Lobelias, a Gypsophila, o
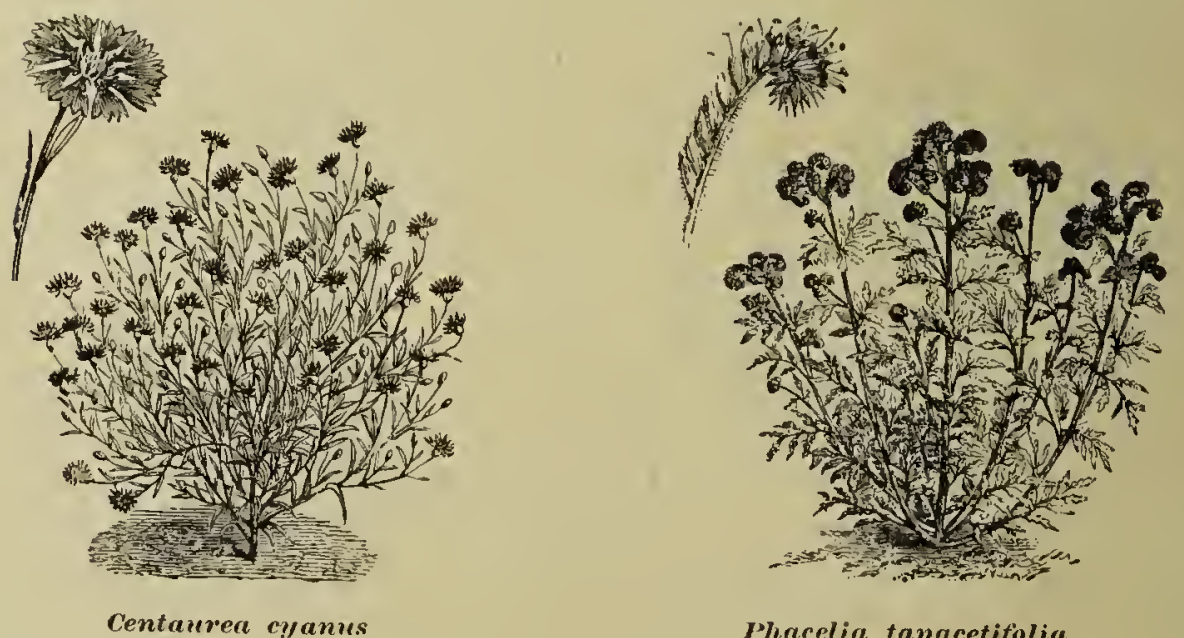

Phacelia tanacetifolia

Eryngiun, os Chrisantiemos singellos, etc., produzem mel e pollen.

As Papoulas são umas espantosas fornecedoras de pollen, 
e dão um mel perfumado e distincto os Craros, a Luzerna, a Centaurea, etc.

A Borragem (Borrago officinalis) e a Phacelia (Phacélia tancuctifolia) cobrem-se de flòres, que são justamente consideradas as rainhas das flôres melliferas. verdadeiros rios de mel.

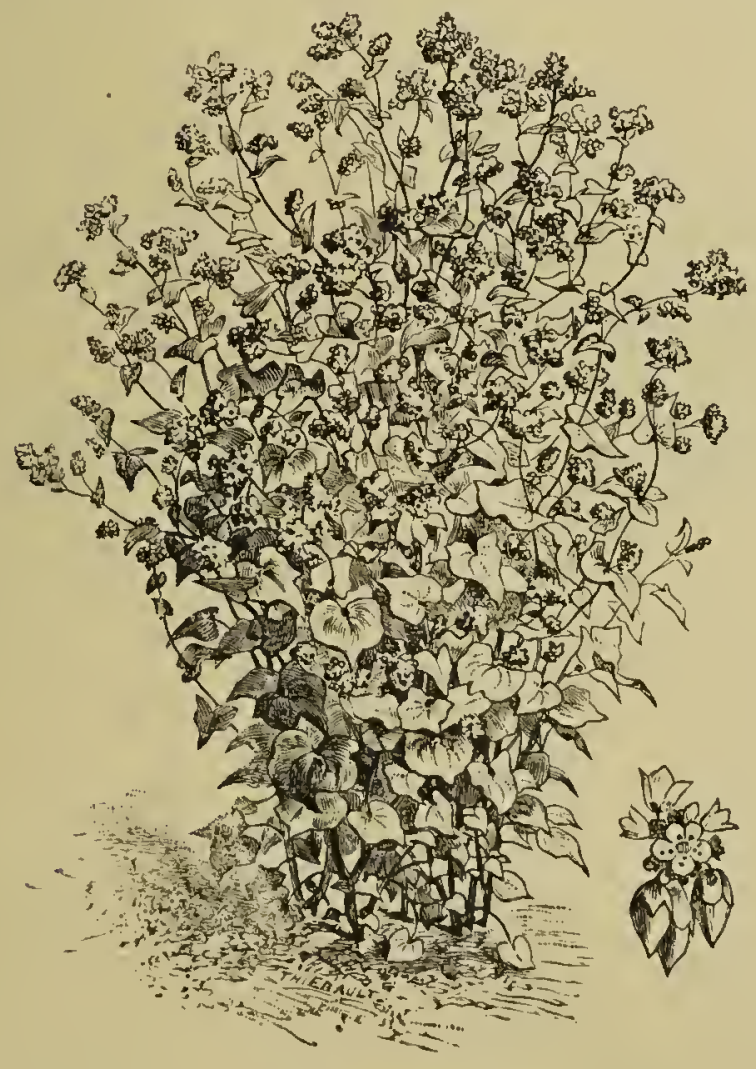

Trigo mourisco

A Bolragem una rez semeada, não mais desapparece dos terrenos, onde se reproduz espontareamente. As folhas são comestireis e as flôres muito utilisarlas para tisanas sudorificas e diureticas.

A Phacelia, originaria da California, é tão rustica conı a Borragem e como ella perpetua-se nos logares oncle uma rez foi semeada. É uma planta bonita, propria para jardim, e un campo semeado com ella póde dar pasto a grande numero do 
colmeias. Depois de secca dá um feno, que o garlo bovino e cavallar come sem repugnancia.

Uma planta que tambem muito conrém espalhar nos

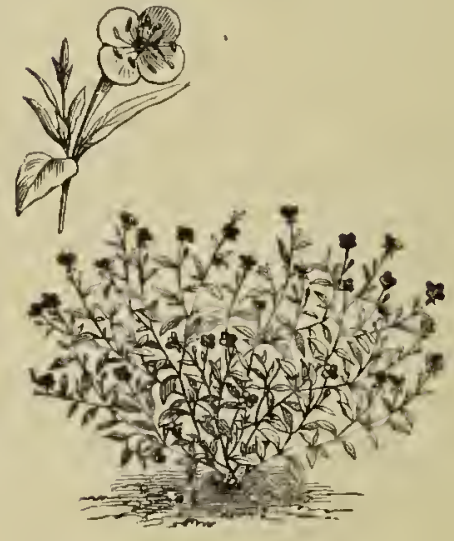

Oenothera rosea

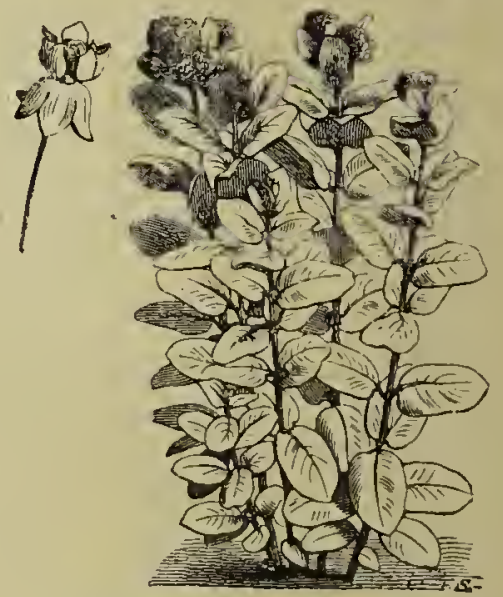

Asrlepias Syriarn on Commet

terrenos seccos, para produç̧ão florifera no verão, é o cardo mellifero Echinops sphaerocephalus, de facil cultura e com muita vitalidade. Floresce de junho a fins de agosto, em um

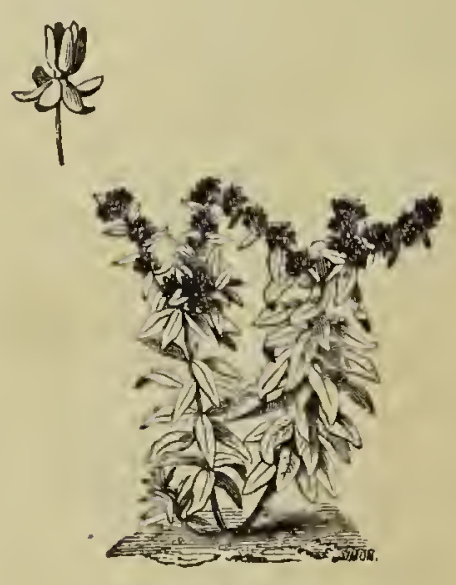

Asclepias tuberosa

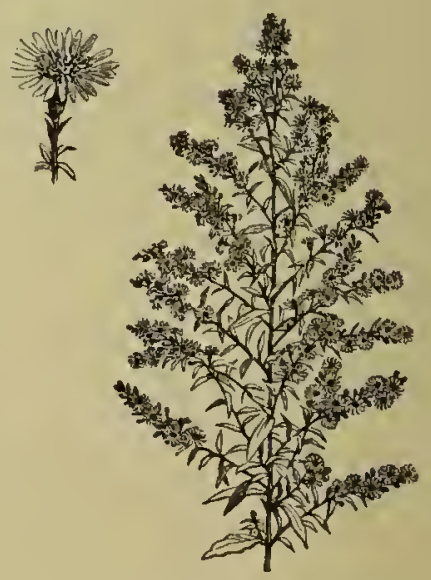

Aster tradescantii

periodo do anno em que as flôres melliferas abumdan pouco, sobretudo nos terrenos aridos. 


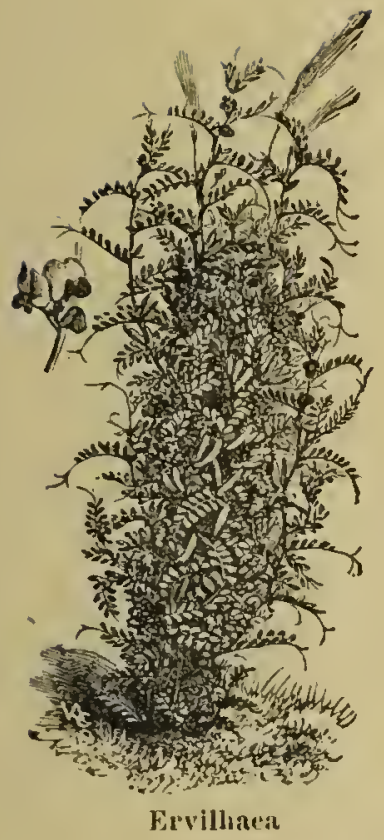

O cardo mellifero prolonga a colheita mellifera e nos annos seccos o a providencia das abellhas, por isso que cada caheça de cardo sc mantém florescente durante mais de uma scmana, consentindo que centenas de abelhas a frequentem constantemente. Isolados, cada cardo póde dar em média vinte e cinco a trinta flôres, pelo que conrém plantal-os a distancia uns rlos outros, approximalimente de um metro.

Outono. O Trigo mourisco dá no ontono um mel escuro, mas de sabor especial muito agradarcl ao paladar. A preciosa Urze dos montes, e as Asclépias, tambem segregam n'esta epocha abundante mel de suas flòres.

o Oenothcra, as Yuccas e o Aster dão mel e pollen, e as flôres das Hcras que se enroscam nos ammosos troncos das arvores, on restem os relhos muros seculares, produzem uma grande quantidade de bom pollon, que as abelhas particularmente apreciam. 


\section{Observações finaes}

Quando a população de uma colmeia ó fúrte, verifica-sc facilmente se tem mestra ou não, mettendo no centro da colmeia um faro rasio. Havendo mestra, dous ou tres dias depois da introduç̧ão, na colmeia, do faro rasio, tem este oros, sendo até muito frequente encontrar-se n'elle a mostra atarefada no scu fadigoso trabalho de postura.

Convém, como já deixamos dito, que carła colmeia de $1 \mathrm{~m}$ colmeal, seja pintada de côr differente; estas côres porém, devem ser claras, pois as còres escuras absorvem muito o calor, o que não convém que se dè, para evitar que no verão a colmeia aqueça internamente, de tal fórma, que faça que a saude das abelhas perigue, e, muito $\mathrm{cm}$ especial, a cêra dos favos derreta, derramando-se o mel.

As colmeias pódem ser pintadas de numa só côr, ás riscas, com a taboa que cobre a entrada de uma côr muito differente, etc. Tambem é util numeral-as, para facilidade de trabalho, permittindo assim que haja um livro onde se tome nota do estado de cada colmeia, onde se faça a sua listoria, o que muito convém ao apicultor cuidadoso.

Nunca se dere mexer nas abellias, seja para o que fồ, sem deitar dentro da colmeia um pouco de fumo, quer pela entrada, quer por cima, e esperar depois uns minutos, para as abellas se encherem de mel. Feito isto as abelhas ficam nuito mais doceis tornando faceis todas as manipulaçōes. Finda a 
operaçĩo é util borrifal-as com agua assucarada, ou agua com mel.

É eonveniente evital o mais possivel grandes gestos ou movimentos rapidos junto das colneias, procedendo-se sempre a todos os trabalhos apicolas com soeego e vagar para não irritar inutilmente as abelhas, o que faria com que muitus fossem sacrificadas sem necessidade alguma.

Mais nma rez repetimos que é preciso haver constantemente agua proximo das colmelas, e isso muito principalmente no inverno, pois n'essa epocha sahindo os prestimosos insectos para longe, á procura do liquido, de que muito carecem. morrem ás centenas com o frio.

E ineonvenientissimo mexer demoradanente, ou mesmo sómente visitar as colmcias las epochas em que estas estiverem quasi exhaustas de mel, pois então as abelhas são irritareis em extremo, visto não tercm o mel preciso para encher o estomago, como sempre fazem quando as perturbam no seu viver socegado.

Na compra de colmeias com abelhas, devem ser escolhidas de preferencia as que tiverem muita população e não as que tirerem muito mel. A população fórte ó a riqueza de toda e qualquer colmeia, a promessa de um futuro desenrolvimento bom. e de magnificas collheitas.

Embora o apicultor tenla colmcias de diversos systemas, derem estas ser todas de tamanho ignal, de fórma que um mesmo quadro sirra en todas ellas. Assim são faceis as maisrariarlas manipulacios apicolas, a troca le faros, o fabrico de enxames altifieiacs, o fortalecimento de colmeias fracas, etc., etc. facilidade que nĩo se daria so carla typo te colmeia tivesse quatros de tamanho direrso.

Nunca se transportam eolmeias cm tempo quente, durante a força lo calor dimmo, pois as abelhas, agitando-se nas colmeias, fazen com que os faros desopereulem c o mel corra, matando-as ás eentenas. Da primarcra ao fim do outono só sc levem transportal as colmeias de noite, e isto apenas em calso execpeional. 
Eis o que, respeito á pilhagem, escreve eloquentemente o sabio apicultor suisso snr. Ed. Bertrand:

"A abelha é essencialmente árida de materias assucaradas, tendo ao mesmo tempo o sentido do cheiro muito desenrolvido.

Prefere a turlo o nectar das plantas, mas, quando elle lhe falta. a sila actividade volta-se a esquadrinhar colleita por toda a parte. não duridando aproveitar-se das provisũes dos visinhos, so isso lhe forr possivel.

Qunando as flôres não dão nada, ha scmpre á volta de carla colmeia alguma exploradora proenrando introduzir-se n'clla e. se consegue illudir a vigilancia das guardarloras e roubar um carregamento de mel, wolta ponco depois con as camaradas. que tentim então entrar á força. As colmeias nas condiçōes normaes, quer dizer quando teem una popnlaç̃̃o ordinaria, nma rainha e creaç̌̃o nova, defendem-se perfeitamente; porém as orphãs fracas em população, on năo possuindo creação, on aquellas cuja entradla estivel muito grandc. nas occasiōes de cscasse\% externa, năo tendo obreiras bastantes para bem a defenderem, on quanito em virtude de um qualquer accidente succedido a $\mathrm{mm}$ favo, on de uma manobra crrada, espalharem $n m$ fórtc ehciro a mel, arriscam-se muito a ser atacadas e roubadas.

As colonias alimentadas artificialmente. e aquellas cujas habitações apresentam fendas, estão ignalmente sujcitas a ser pillıadas.

O sustento, á excepcrão do mel cm favo e do assucar no estaulo solido, on em pasta, deve sempre ser dado de tarde e retirado do manhã, se ainda então houver algum no alimentador.

As entradas precisam ser reduzidas an minimo, apenas ao espaço suffieiente para a passagem de uma on duas abelhas o ınıito, para as colonias muito fracas, orphãs ou trasvasalas de fresco, emquanto honver pequena produção de nectar.

0 cheiro do mel on do xarope espailiado enturiaga as abelhas: as que podéram entregar-se á pillagem d'una colmeia visinha, ou apoderar-se de substancias assuearadas deixalas imprudentemente ao sen alcance fóra das colmcias, ficam excitadissimas $\mathrm{cm}$ alto grau, lançando-se sobre as ontras colonias, o que póde degenerar cm uma batalha geral no colmeal. E, sobretndo na primavera, depois da primeira colheita de mel, que é preciso exereer uma grande rigilancia. Uma colmeia que ficon aberta, 1 m favo de mel esquecido fóra, algum xarope trasvasarlo, pódem oecasionar as mais grares consequencias más. Para evitar isto, torlas as manipulaçies com o mel devem ser feitas em $n$ local fechado, scm abertıra alguma. Já vimos uma casa, onde se extrahia mel em ima sala aberta, litteralmente cercada; as abelhas combatiam umas com as outras no colmeal 
c atacavam todos quantos passavam pela rua. que era proximo. N'estas occasiões é preciso acantelar todos os animacs, a queın ellas aggridem despiedadamente.

Desordem igual tamben se den $\mathrm{cm}$ nm colmeal, ondc desenidadamente deixaram aberto $11 \mathrm{n}$ armario, que servia para guardar favos com mel. Depois da pilhagem tomar $\mathrm{nm}$ eerto desenvolvimento é difficil fazel-a eessar; supprimicla a cansa original, é preciso diminuir as entradas de torlas as colmeias, e borrifar eom agua (em fórma de chura) aquellas ondc a pilhagem sc den. Tambem é eonveniente collocar sobre a plancheta de entrada da colmeia saqneada, im trapo embcbido em acido phenico, transformar a cntrada em comprido desfilarlciro por meio te um pequeno canal, inclinar nma lamina de virtro diante da cutrada, etc. Estes meios dăo algumas vezes resultado; algumas re\%es si. porque no geral de pouco servem.

Depois de tndo socegalo, sete on oito dias mais tardc, angmentan-se proporcionalmente as cutralas das colmeias conforme as necessilades das abclias.»

Um apiario nunca dove ser montado proximo das fabricas de refinaçĩo, doçarias, etc., pois, além de constantes questĩes desagradareis com os visinhos, ver-se-hia diminuir dia a dia a população dlas colmeias, morta estupidamente aos millares nas calcleiras de refinação, on nos apparellos de preparo de doce rlos confeiteiros. Além d'isto o mel fabricado com assucar é mnito ordinario, sem perfume c fermentando facil e promptamente.

As alçals nunca se pũem cerlo nas colmeias mas só no momento da grande producęĩo mellifera, pois cedo arrefecem muito a colmeia, o que a enfraquece bastante. Tambem nunca deve esquecer o separar as alças do corpo da colmcia por meio das laminas de zinco, afim de que a mestra nãu rá fazer pustuía nos quadros de seçũes.

O apicultor americano Porter, inrentou recentemente 1 m apparelho a que den o nome de emrota-abelhas, que muito facilita a collocita de mel nas alças das colmeias.

Para isto, antes de se proceder á extraç̧ão dos faros das alças, fixa-se $u m$ ou mais enxota-abelhas, em uma taboa com aherturas porporcionaes ao apparelho, taboa que se colloca entre a alça e a colmeia. As abchas separadas pela divisão de 
madeira abandonam a alęa para entrar no corpo da colmeia, impellindo duas laminas metallicas muito finas e leves, que

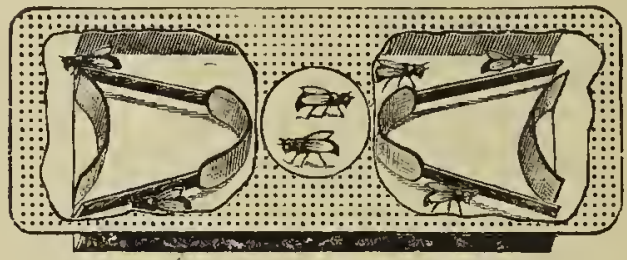

Enxota-abelhas Porter tapanı a abertura do pequeno apparelho. Estas laminas deixam sahir as abellias da alça para a colmeia, nıas não voltar do corpo da colmeia para a ilça. Assim collocada a taboa com os enxotcabellerss, de manhã, á tarde ou. o muito, no dia seguninte, está a alça rasia de abelhas, podcndo ser tirada facilmentc sem incommodar nem irritar a colonia.

o traspassamento de colmeias precisa de ser feito nem cedo nem tarde de mais: a melhor epocha entre nós ó do meio de março ató ao fim de abril, quando o tempo estiver quentc.

Nos traspassamentos de cortiço para cortiço bate-se sempre de baixo para cima. Os traspassamentos de cortiço para colmeia movel, lançando as abellas sobre umı panno, devem ser feitos ao resto da tarde e não na força do calor, em que o enxame póde lerantar vôo e fugir para longe.

Os favos que se pôen no extractor, em face uns dos outros, é preciso que scjam proporcionalmente do mesmo peso para o apparelho funccionar bem. Começa-se sempre a trabathar com o extractor vagarosamentc, para evitar accidentes, e só depois de algumas dezenas de voltas é que se póde dar mais força ao apparelho.

E. de toda a conveniencia o não aproveitamento dos faros desoperculados, pois n'estes o mel não está maduro, possuindo muita agua, que mais tarele cstraga o mel, fazendo-o formentar cedo.

Depois de tirado por moio do extractor o mel dos favos, guardam-se os que ficaram mais perfeitos, afim de se introduzirem nas colmeias em occasião de colleita abundante, pois as abelhas encontrando favos feitos, dedicam-se só á apanlıa do 
nectar, encbendo assim os depositos em poucos dias, risto terem poupado o enorme dispendio de tempo, cêra e mel precisos para os construir.

No inrerno não deve nunca harel esquecimento em fornecer alimento ás colmeias que d'elle necessitarem. A falta de alimento, durante os grandes frios, é a principal causa do aniquilamento da maior parte das colmeias. $O$ alimento em xarope dere sempre ser fornecido apenas o preciso e nunca em excesso.

Para uma colmeia passar bom o inverno necessita de população fórte, que as provisões regulem de dez a vinte kilos, conforme o tamanho da colmeia (sempre antes de mais do yne de menos) e a capacidade d'esta scja, pelo menos, de yuarenta litros, a casa bem confortavel e resguardada do friu de modo que conserve un calor uniforme e constante, que é a saudc da população, do que resultará uma creaçio numerosa, e precóce na primavera. Depois d'isto o muito importante o arejamento. O snr. Legrain communicon a sociedale central de apicultura e insectiologia franceza, na sessão rle 20 de mare de 1895 , as suas observacioes feitas no inverno de $1894-95$ respeito an arejamento das colmeias, assererando que muitas das suas colmeias, levantalas tres millimetros sobre cunhas, de modo a serem ben arejadas, libernaram perfeitamente, emquanto que lloutras, collocadas junto das primeiras mas sem cunlıas, as pertas fòram muito grandes, o bolor invadiu-lhes os faros, e os supportes estavam cheios de cadaveres de abellas em putreficção. Não bastou portanto para a boa ventilação d'estas ultimas colmeias a abortura de entrada de vinte centimetros. O snr. Grémy Saint Peć, fez tambem, na mesmo opocha, ohservaçoes identicas, e o sur. Layens viu no Eure, em 1879, colmeias erguirlas a ponto de se pordor passar a mĩo por baixo, hibernarem perfeitamente apesar $11 \mathrm{~m}$ constante frio intensissinno.

Este excesso de ventilạão no iuverno, que á primeira rista parece $\mathbf{n m}$ erro, tem a sua razão de ser, por isso que expelle o acido carhonico e a humidade proveniente da res- 
piração das abellıas e que thes é muito prejurlicial. A ventilação é relativamente mais precisa de inverno, pois n'essa epocha é que ha excesso de carbone e de humilade, em virturle da constante agglomeração das abellias no centro da colmeia, e da decomposição chimica do mel, que, queimado no pulmão das abellıas, dá muito acido carbonieo e rapor d'agua. O acido carbonico, em virtude la sua densidade, occupa a base da colmeia, e o rapor d'agua condensa-se nas paredes, onde, quando o frio é em excesso, chega a gelar; véem depois as chuvas $e$ as rariantes de temperatura, muito frequentes no nosso paiz, dá-se o derretimento e uma repentina invasão de humidade, que enche os favos de cogumellos, molha as abelhas e estraga o mel que, pela sua vez, origina a diarhéa, tornando a habitação completamente insalubre.

A humidade en uma colmeia fórte e mal ventilada faz prejuizos proporcionaes á população, prejuizos de que muitos apicultores nem sequer suspeitam. De inverno, nos sitios humidos, para que o ar circule mellor, 6 sempre conveniente inclinar as colmeias. De verão, para harer a conveniente ventilação basta angnentar á abertura de entrada e abrir os orificios de entrada d'ar, gerahmente situados na base da culmeia e cobertos por fina rère de arame.

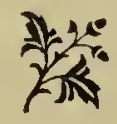




\section{N D I C E}

\section{DOS CAPITUI,OS}

P'A.

Jim,ves gernes sobre os insectns. - Os hymenoptéros. - l'apel que denempenlam na focundag̃o dos regetaes . . . . . . . . . . . .

Rosumo hicturieu das descubertas solre as ahelhas. - Maraldi, Swammerdau, Reanuur, Schirach e Huber. . . . . . . . . . . . . . 11

Anatomia e physiolugia das abellas. . . . . . . . . . . . . . 2.2

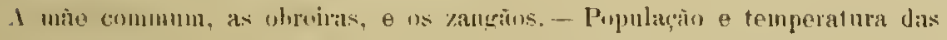
colıneias.

A irritahililale dus abelhas . . . . . . . . . . . . . . . . 4 4

() enxame. A apanha dos enxames. Enxames nutnraes $\theta$ enxamos artificlilos . . . . . . . . . . . . . . . . . . . 5 52

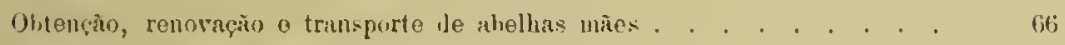

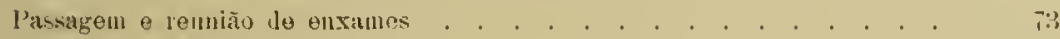

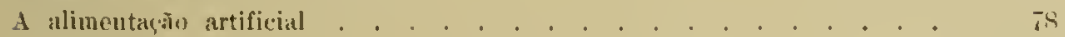

A architectura las abelhas. . . . . . . . . . . . . . \$2

As substancias colhidas, -0 nectir, o pollen, " propolis e a arua. . . . sib

As substancias produzidas, -0 mel . . . . . . . . . . . . \$1

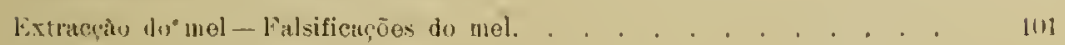

(1) mel como hebida. - o hydromel. - o mel no riuho. - Tinagre, alconl, cervejn o lieures to mel. . . . . . . . . . . . . . . . . Ilk

O mel eomo nimento. - Inmarias e doces fahricados eom mel . . . . . 12.t

(1) nus emo renealio. . . . . . . . . . . . . . . . . . . 15̆

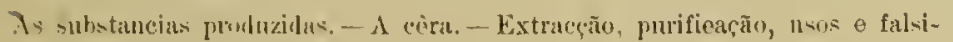
fieaçũos da eêra. . . . . . . . . . . . . . . . . . . 11\%2

luimigos o doeners das abelhas. -1 intelligoncia das abelbas . . . . It

U fixisino e a autiga apicultura portnernezal. . . . . . . . . . . . 1!:3

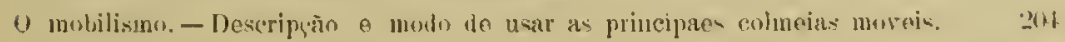

A cêra moldula . . . . . . . . . . . . . . . . . . . . . . . .

Cialendario spicola. . . . . . . . . . . . . . . . . . . . mbs

l.egislaçăo apicela. . . . . . . . . . . . . . . . . . . . . 2 20?

A flora apicola. - Plantas a cultivar para a prodneçăs do pollen e do nectar . . . . . . . . . . . . . . . 2602

Observacues finues . . . . . . . . . . . . . . . . 281 


\section{DAS GRAVURAS}

P'Án.

A mãe borboleta.

Escararêlho ou Bosouro . . . . . . . . . . . . . . . . . . .

A monca . . . . . . . . . . . . . . . . . . . . . 4

А pulga . . . . . . . . . . . . . . . . . . . . . 4

0 mosquito trombeteiro. . . . . . . . . . . . . . . .

A borboletia . . . . . . . . . . . . . . . . . . . त

As formigas. . . . . . . . . . . . . . . . . . . . . 6

A libellinha. . . . . . . . . . . . . . . . . . . . . . f

O persevejo. . . . . . . . . . . . . . . . . . . . . 7

O pulgăo do pecegueiro. . . . . . . . . . . . . . 8

0 gafanhoto. . . . . . . . . . . . . . . . . . 8

A caura loura . . . . . . . . . . . . . . . . . . . \&

Abelhas fecundando orchideas . . . . . . . . . . . . . . 10

Microscopio simples . . . . . . . . . . . . . . . . . 14

Infusorios do vinawre . . . . . . . . . . . . . . . . 14

Monadas . . . . . . . . . . . . . . . . . 14

Rotiforos. . . . . . . . . . . . . . . . . . . . . . 1.1

Microscopio composto . . . . . . . . . . . . . . . . . 15

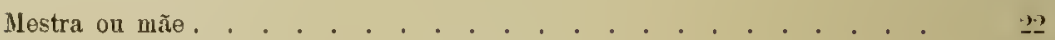

Obreira . . . . . . . . . . . . . . . . . . . . . 22

Macho ou Zangrio. . . . . . . . . . . . . . . . . . . . 2.

Cabera de rainha. . . . . . . . . . . . . . . . 23

\& de obreira . . . . . . . . . . . . . . 23

» do macho. . . . . . . . . . . . . . . . . . 23

Mandibula do obreira. . . . . . . . . . . . . . . . . . . 24

Pata da abelha. . . . . . . . . . . . . . . . . . 2 26

Glandula segrregadora da cêra . . . . . . . . . . . . . 28

Glanỏula salivar da abelha obreira. . . . . . . . . . . . . . 29

Apparelho venenoso da abelha obroira - $a$, aguillıno - b, reservatorio de vonono $-c, c, d, d$, tubos segregadores do voneno. . . . . . . . 3:2

Abolha uño da Apis mellifica . . . . . . . . . . . . . . . . \$ 36

fraiola do toia metallica para femea mãe. . . . . . . . . . . . ¿

Obreira da abolha italiana (Apis ligustica). . . . . . . . . . . . 37

Ubreira dit abelha egypcia (Apis fascicta) . . . . . . . . . . . 38

Larva da Apis mellifica. . . . . . . . . . . . . . . . 4 40

Nympha da Apis mollifica. . . . . . . . . . . . . . . . . 4t 4

Obroira da abelha europeia (Apis nellifica) . . . . . . . . . . . 41

Macho ou zangão da Apis mellifica. . . . . . . . . . . . . . . 41 
PAG.

Armadilha para apanhar os zangĩos . . . . . . . . . . . . . . 42

Mascara de rèdo motrllica . . . . . . . . . . . . . . . . 48

Veu de tule. . . . . . . . . . . . . . . . . . . . 4 48

Luvas do algodão. . . . . . . . . . . . . . . . . . . . . . 19

O enxame . . . . . . . . . . . . . . . . . . . . . . . . . . 54

Cellulas reaos on do abelhas wãos. . . . . . . . . . . . . . . . . . . .

Cinco furado para deter es machos e fomeas màes . . . . . . . . . 万ั

Nollo Bingham. . . . . . . . . . . . . . . . . . . . . 5

Resguarlo metallicu dos alveolos de mestra . . . . . . . . . . Gs

Caixa Benton para transporte do mãos . . . . . . . . . . . . . . 70

Craiola cyliudrica para introduzir as unà mos enxames . . . . . . . TI

Nimentador rapido . . . . . . . . . . . . . . . . . . . 80

Alimentadur de entruda. . . . . . . . . . . . . . . . . . . . . 81

Nimentadur aperfeiçoado . . . . . . . . . . . . . . . . . . . 81

Abella construindo um alreolo. i diroila ostäo alroolos roaes. . . . 83

Faro com alveolos irregularen, alveolos pequenos de obroiras o alveolus

grandes do machos. . . . . . . . . . . . . . . . rt

Avenlos de abelha mestra. . . . . . . . . . . . . . . . . . .

Aluelha laubendo o nectar ua baso do uma folha lo ervilhaca. . . . . 8i;

Massa pollinica da Orelis macrulata . . . . . . . . . . . . . . . 8 -

Anthera do lonroiro com os sens saccos pollinicos . . . . . . . . 87

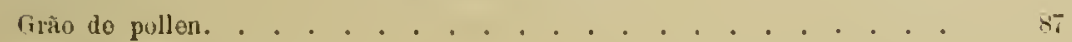

Grão de pollen do melão . . . . . . . . . . . . . . . . . . 8 .

Grĩo de pollen da alcea . . . . . . . . . . . . . . . . . . . . .

Estames lançando miriades de gràos de pollen . . . . . . . . . 8 8

Uwa abelha colhendo pollen na flôr da papoulat, o outra voanto já com

polotas do pollon nas costas das pernas trazeiras . . . . . . . . s 89

Desoperculador Bingham . . . . . . . . . . . . . . . . 102

Pronsa para espremer os faros . . . . . . . . . . . . . . 11:3

Cachimbo proprio para deitar fumo uas colmoias . . . . . . . . . 11:3

Faca para lespegar os quadros . . . . . . . . . . . . . . . 1114

Extractor do mol. . . . . . . . . . . . . . . . . . 10t;

l'urificador solar . . . . . . . . . . . . . . . . . 16.5

Caldeira Bourgeois para derreter a cèra a vajur. . . . . . . . . . 16t

Marmitu de lata para lerreter a cèra a banho maria . . . . . . . . 16:

Sotaria rerfucilluda. - A Planta intoira - B Espiga-C Fragmento augmen-

tado da espiga mostrando as barbulas com arpões. . . . . . . .

Apparulho ostaminal da Aranja cericifora. - A Trumba - I3 lietinaculo --

C Massas pollinicas . . . . . . . . . . . . . . 181

1 tiuba da cèra . . . . . . . . . . . . . . . . . 182

Larra ou lagarta da tinha. . . . . . . . . . . . . . . 182 
Galeria constrnida pola tinha $\theta$ isolada do favo . . . . . . . . 183

Casulos agglomerados da tinha . . . . . . . . . . . . 18:

Pinça para agarrar as larras das tinhas. . . . . . . . . . . . . 1 1 14

Favo atacado pola tinha . . . . . . . . . . . . . . 185

A vespa . . . . . . . . . . . . . . . . . . . . 185

Os vespões . . . . . . . . . . . . . . . . . . . . . . 186

o caracol. . . . . . . . . . . . . . . . . . . 186

A lesma . . . . . . . . . . . . . . . . . . . . . . . 18т

- A Philante apivora natando uma abelha. . . . . . . . . . . . 18i

A aranha. . . . . . . . . . . . . . . . . . . . 187

Meloe moscarabous fenea . . . . . . . . . . . . . . . 188

Meloe proscarcboms macho. . . . . . . . . . . . . . . . 188

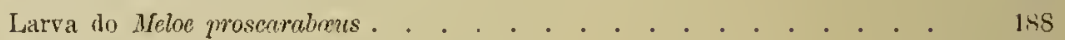

Heloe variegatus fomoa . . . . . . . . . . . . . . . 18

Larva do ffeloc variegutus. . . . . . . . . . . . . . . . . 1RS

Clerus nu Trichodes apiurius. . . . . . . . . . . . . . . . 1 RS

O Braula caeca on pulga da abolha . . . . . . . . . . . . . . 189

Trichodactyhs osmine . . . . . . . . . . . . . . . . . 1 . 1 9

0 sardão. . . . . . . . . . . . . . . . . . 1 . . . . . . .

A sardonisca . . . . . . . . . . . . . . . . . 1 . . . . .

0 sаро . . . . . . . . . . . . . . . . . . . 1011

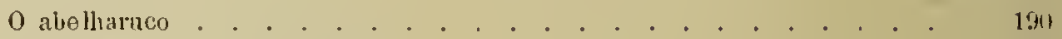

A Sphimx on Achcrontia alronos . . . . . . . . . . . . . . 192

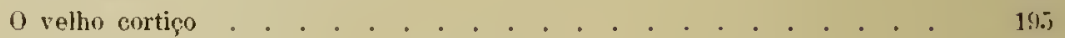

Cortico sob abrigo de palla . . . . . . . . . . . . . . . . 1960

Colmeia vulgar de palha . . . . . . . . . . . . . . . . 2 . (x)

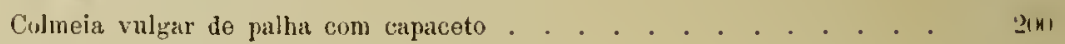

Colucia normanda de calotte on capacete . . . . . . . . . . . 201

Culmoir de palha com alça . . . . . . . . . . . . . . . . . . (1)

Colneia Teynac . . . . . . . . . . . . . . . . . . 217

Colıneia Gariel . . . . . . . . . . . . . . . . . . . . 212

Colmeia Sequeira . . . . . . . . . . . . . . . . . . . . . 214

Quadro com côra moldada. . . . . . . . . . . . . . . . 214

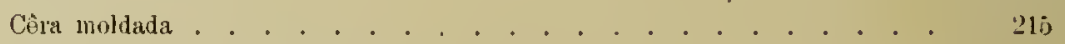

Rolla para cortal cèra moldada . . . . . . . . . . . . . . . 215

Molo de fixar as tiras do cêra nos quadros. . . . . . . . . . . 215

Fixa-ganchos Paschoud. . . . . . . . . . . . . . . . . 216

Ganchos. . . . . . . . . . . . . . . . . . . 216

Novello de fio de arame estanliado. . . . . . . . . . . . . . 216

Quadro com araese . . . . . . . . . . . . . . . . . 216

Esporão Woiblet . . . . . . . . . . . . . . . . . . 216

Hodo de empregar o Esporão Woiblet para fixar a côra hos arames . . 2 217 
P.A.

Zinen furado para detor as abelhas mestras e os machos . . . . . . . 217

Alea com quadros. . . . . . . . . . . . . . . . . . . . . . 218

Seçăn aberta . . . . . . . . . . . . . . . . . . . 218

Secção fecliala e prompta a sel utilisada . . . . . . . . . . . . 219

Fixuẹño das pequenas tiras de còra nas secçues. . . . . . . . . . . 219

Alç Benthall para secceres . . . . . . . . . . . . . . . . . 21?

Simparaphn de tres soçües. . . . . . . . . . . . . . . . . 2.21

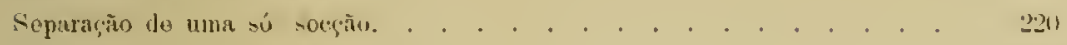

Quallo com sergùes. . . . . . . . . . . . . . . . . . 2.20

Seprarão verticnl . . . . . . . . . . . . . . . . . . . . . 20

Pelestal do madeira para colmoia . . . . . . . . . . . . . . 21

Colmeia Cowan. . . . . . . . . . . . . . . . . . . . . .21

Coluseia Langstruth . . . . . . . . . . . . . . . . . . . . . . 2

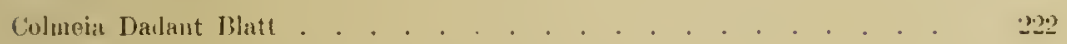

Culmoia Liljéns . . . . . . . . . . . . . . . . . . . . . . . . . . . . . . . . . .

Colmeia economica Layens prepatuda para a hibernacto . . . . . . . 206;

Colmoia Gajtom . . . . . . . . . . . . . . . . . . . . . 2.2-

Colmeia Ahbott . . . . . . . . . . . . . . . . . . . 228

Colmeiar allum Dorusne . . . . . . . . . . . . . . . . . . . 3:k

Ginulro do creageion . . . . . . . . . . . . . . . . . . . 281

Juda de manobrar extermamento os quadros . . . . . . . . . . . . 2931

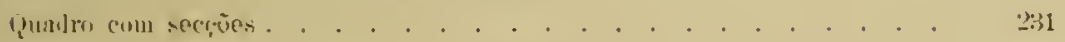

Cilneia de olservagiono . . . . . . . . . . . . . . . . . 298

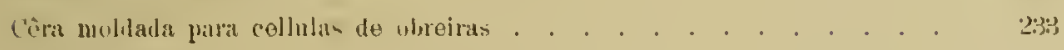

I'rensar Rietsche. . . . . . . . . . . . . . . . . . . . 235

Cylindragem do cêra pelo cylindro Root. . . . . . . . . . . . 2366

Alimontador grainado . . . . . . . . . . . . . . . . . . . 213

Larva da tinha . . . . . . . . . . . . . . . . . . . . . . . . 24

burlolota ta tinha . . . . . . . . . . . . . . . . . 214

Faca para extrahir os favos . . . . . . . . . . . . . . . . 249

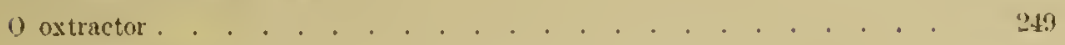

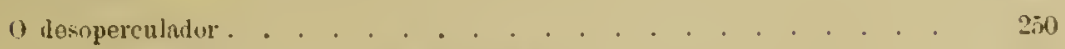

l'rensa para extrahir o mol dus restos lus favos. . . . . . . . . . 251

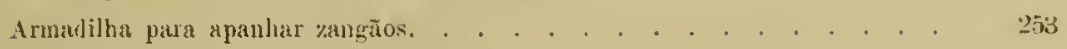

Culmoia Layens com alrigo de palha para o inverno . . . . . . . . 257

Saltia pratensis . . . . . . . . . . . . . . . . . . . . 963

Solidagn rirga aurat. . . . . . . . . . . . . . . . . . . . . 263

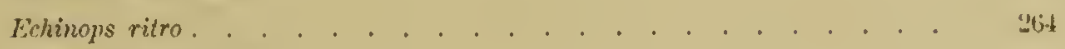

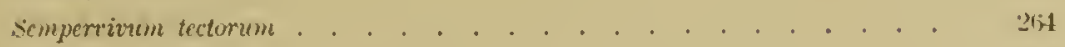

Shakespeare Aster. . . . . . . . . . . . . . . . . 264

Gomos d'arvore . . . . . . . . . . . . . . . . . . . 265

Rebentos d'arrore. . . . . . . . . . . . . . . . 265 
Crocus ou Açafrăo . . . . . . . . . . . . . . . . . . . . . . . . . . 266

Floresconcia da cerejoira . . . . . . . . . . . . . . . . . 271

Morangueiro. . . . . . . . . . . . . . . . . . . 271

Trevo branco . . . . . . . . . . . . . . . . . . . . $2{ }^{2}$

Trevo da Siberia. . . . . . . . . . . . . . . . . 272

Trevo hybrido ou d'Alsika . . . . . . . . . . . . . . . . . 273

Aquilegic stellata. . . . . . . . . . . . . . . . . . . . 273

Sanfeno commrm. . . . . . . . . . . . . . . . . 274

Fuchsias. . . . . . . . . . . . . . . . . . . . 275

Polygonum orientalc . . . . . . . . . . . . . . . . . 275

Terbena hybrida. . . . . . . . . . . . . . . . . 275

Clematis Fortunei. . . . . . . . . . . . . . . . . . . . .

Rainha Margarida. . . . . . . . . . . . . . . . . . . 276

Chrysanthesnum ourinatum. . . . . . . . . . . . . . . . . . . 276

Lirin convallo . . . . . . . . . . . . . . . . . . . . . . 2 $2 \pi$

Cleome pungens . . . . . . . . . . . . . . . . . . . . .

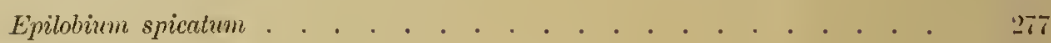

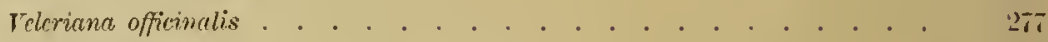

Imula glandulosa . . . . . . . . . . . . . . . . . . . .

Tussilago frayrans. . . . . . . . . . . . . . . . 378

Lobelia eardinalis . . . . . . . . . . . . . . . . . . $27 \%$.

Gypsophile degans . . . . . . . . . . . . . . . . . . . . $27 s$

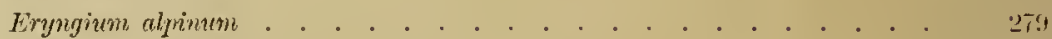

Luzerna da Provençă . . . . . . . . . . . . . . . . . . . 2:

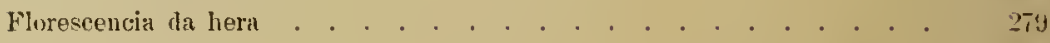

Luzerna lupulina . . . . . . . . . . . . . . . . . . . . . . . 2!

Burragem. . . . . . . . . . . . . . . . . . . . . 20811

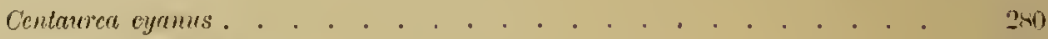

Phacclia lanacctifolia. . . . . . . . . . . . . . . . . . 290

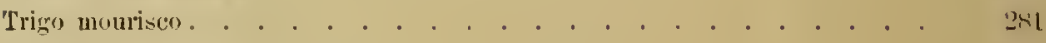

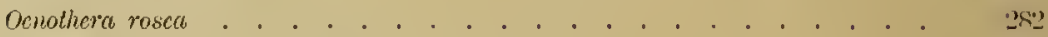

Asclopias Syriaca on Cormuti. . . . . . . . . . . . . . . . . . . . .

Asclopias tuberosa. . . . . . . . . . . . . . . . . . . . . . 28'

Aster trulescantii. . . . . . . . . . . . . . . . . . . . 242

Ervilhrea . . . . . . . . . . . . . . . . . . $28 \%$

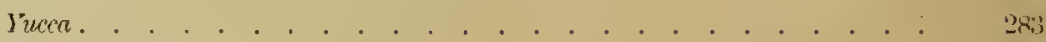

Enxota-ahelhas rorter . . . . . . . . . . . . . . . 2 28s

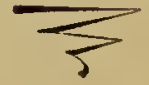



$16+13391 / 4$ 
(1)

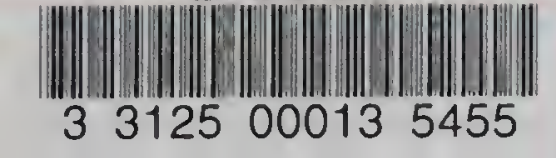

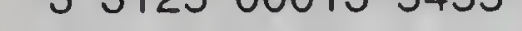

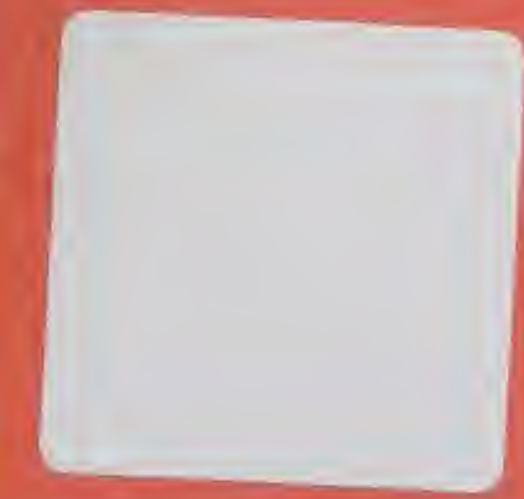


